US Army Corps

of Engineers ${ }_{\circledast}$

Engineer Research and

Development Center

\title{
Bonneville Second Powerhouse ERDC Turbine Model Operating Range Investigation
}

Robert A. Davidson

August 2018

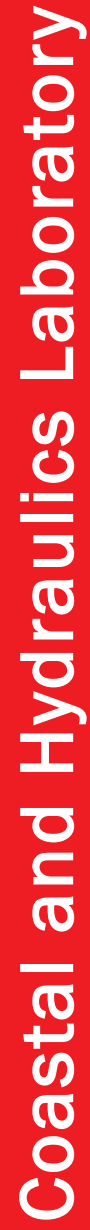

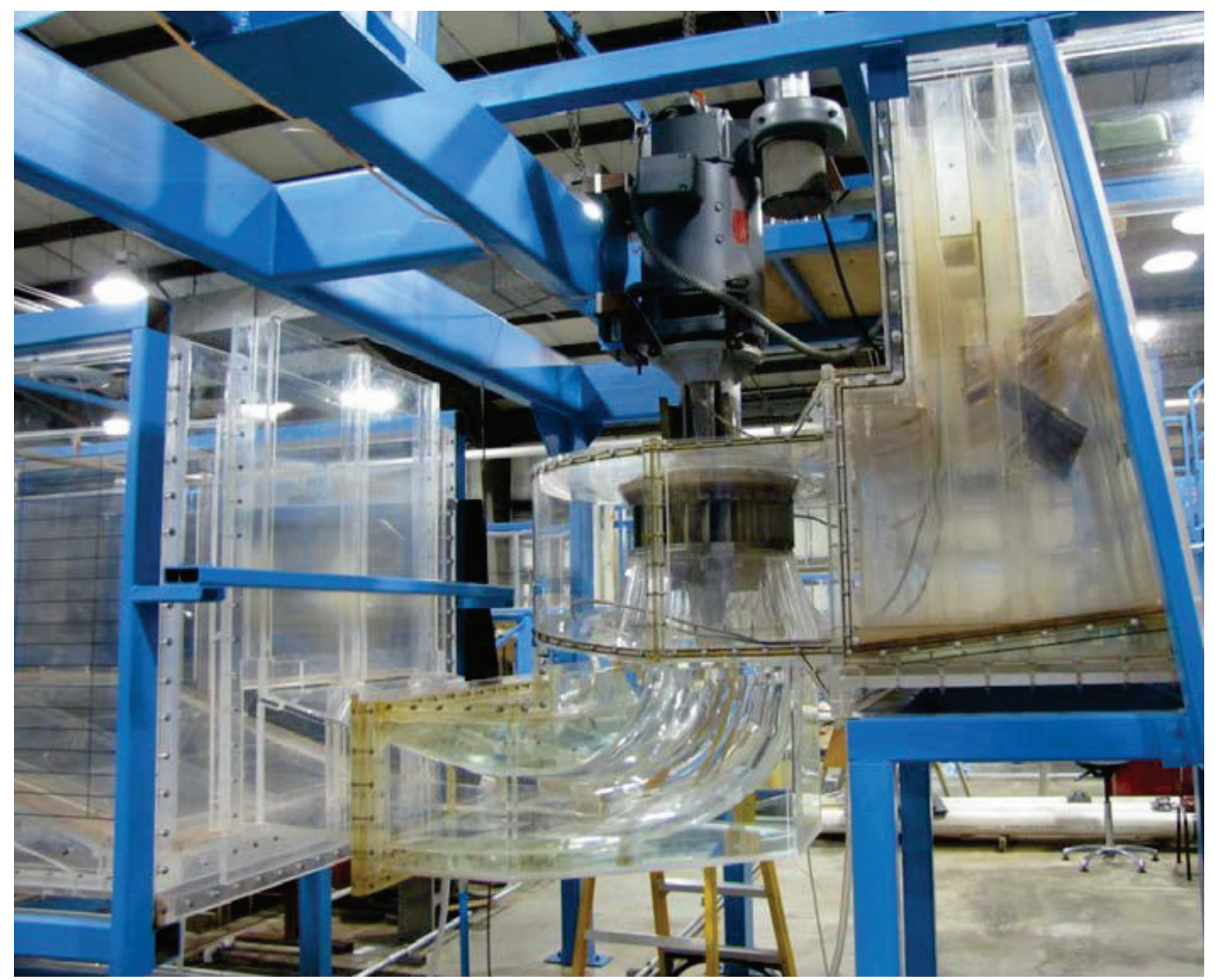


The U.S. Army Engineer Research and Development Center (ERDC) solves the nation's toughest engineering and environmental challenges. ERDC develops innovative solutions in civil and military engineering, geospatial sciences, water resources, and environmental sciences for the Army, the Department of Defense, civilian agencies, and our nation's public good. Find out more at www.erdc.usace.army.mil.

To search for other technical reports published by ERDC, visit the ERDC online library at http://acwc.sdp.sirsi.net/client/default. 


\title{
Bonneville Second Powerhouse ERDC Turbine Model Operating Range Investigation
}

\author{
Robert A. Davidson \\ Coastal and Hydraulics Laboratory \\ U.S. Army Engineer Research and Development Center \\ 3909 Halls Ferry Road \\ Vicksburg, MS 39180-6199
}

Final report

Approved for public release; distribution is unlimited.

\author{
Prepared for U.S. Army Corps of Engineers \\ Washington, DC 20314-1000 \\ Under Work Unit 157101, "CRFM SYS-S Turbine Bio Index Test”
}




\section{Abstract}

The Bonneville Second Powerhouse (B2) turbine model investigations were performed in support of the joint U.S. Army Corps of Engineers, Portland and Walla Walla Districts, Turbine Survival Program (TSP). The TSP was developed to evaluate juvenile fish passage through turbines, with emphasis on identifying turbine structures and operations responsible for fish injury. The purpose of this B2 turbine model study was to investigate potential risk of injury to juvenile fish passing through all regions of the B2 turbines water passageway, using the existing 1:25 scale physical hydraulic model of the $\mathrm{B} 2$ turbines. The model investigations were divided into five study areas. These include the stay vane and wicket gate cascade, the runner, the region immediately below the runner, the exit of each of the two draft tube barrels, and the immediate tailrace region. Results from this model investigation indicate operations with steeper blade angles, resulting in higher unit discharge, create better passage conditions for fish. Fewer severe contacts with the turbine runner and less severe change in direction occur at steeper blade angles. The draft tube performs better at steeper blade angles, and the quality of flow exiting the draft tube is better at steeper blade angles. In addition, model experiments indicate egress conditions may be better at steeper blade angles.

DISCLAIMER: The contents of this report are not to be used for advertising, publication, or promotional purposes. Citation of trade names does not constitute an official endorsement or approval of the use of such commercial products. All product names and trademarks cited are the property of their respective owners. The findings of this report are not to be construed as an official Department of the Army position unless so designated by other authorized documents. 


\section{Contents}

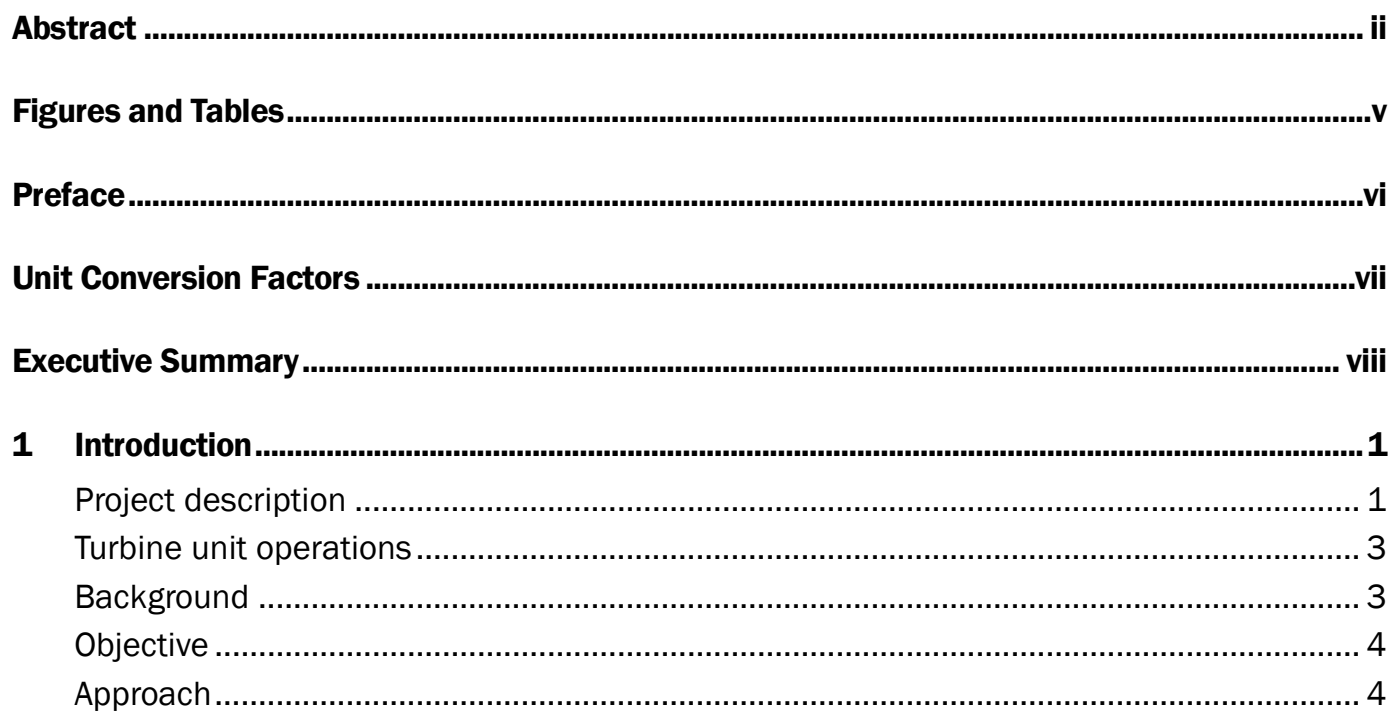

2 Physical Model.................................................................................................................... 5

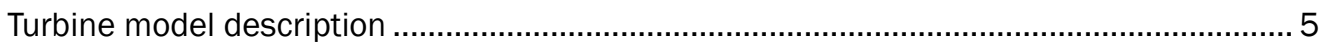

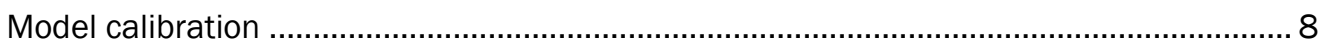

Inflow meter calibration .............................................................................................. 9

Wicket gate calibration ................................................................................................. 9

Runner speed calibration ............................................................................................. 10

Blade angle calibration ......................................................................................... 10

Model similitude .......................................................................................................... 11

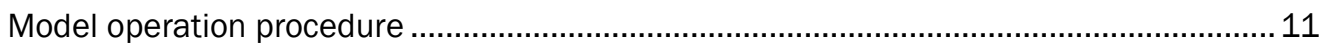

3 Model Experiments Approach ...............................................................................................14

Model test conditions and investigations .............................................................. 14

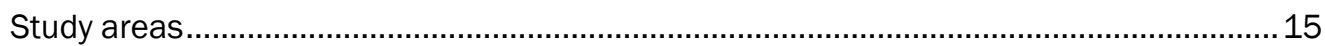

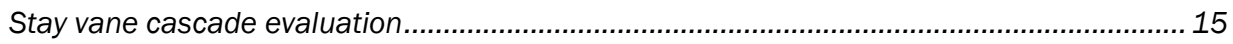

Turbine runner evaluation ............................................................................................. 16

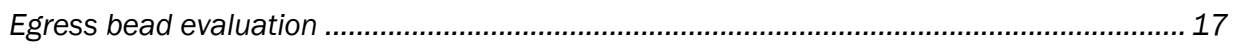

4 Model Evaluation Techniques ..............................................................................................18

Data acquisition with laser Doppler velocity (LDV) meter ................................................ 18

Data acquisition and analysis with neutrally buoyant beads ............................................ 19

Test bead sample size ............................................................................................. 22

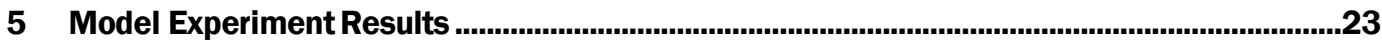

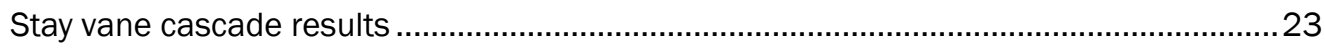

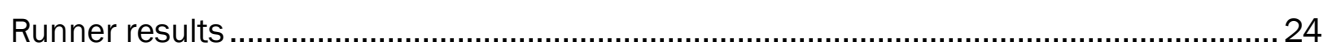

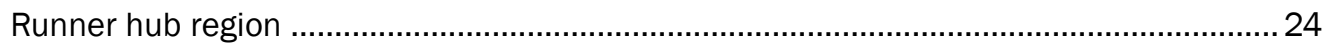

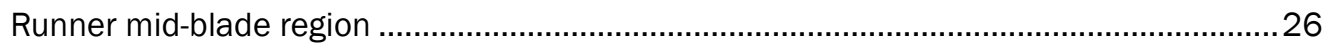

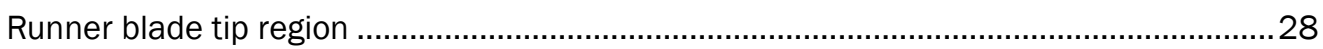




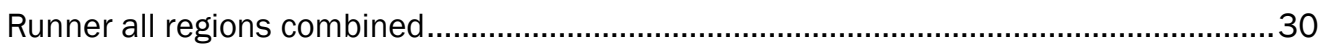

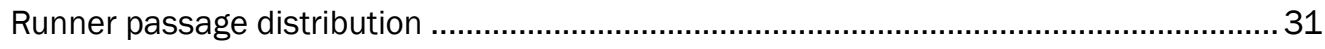

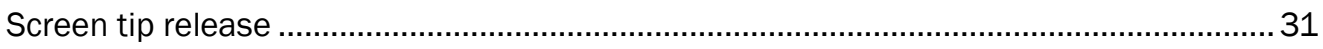

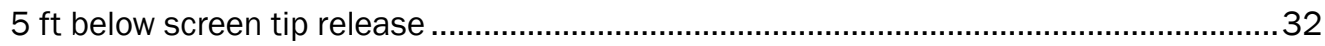

$15 \mathrm{ft}$ below screen tip release .......................................................................................... 33

Combining screen tip and $5 \mathrm{ft}$ lowered releases............................................................... 33

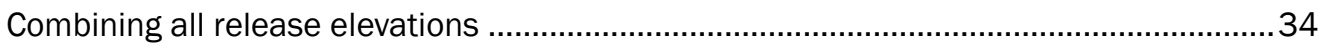

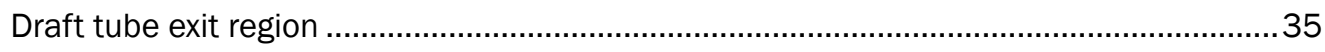

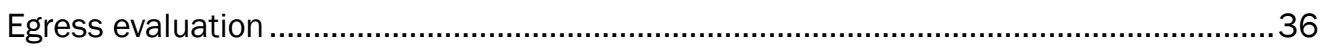

6 Model Target Operating Range (TOR) Conclusions and Recommendations ........................39

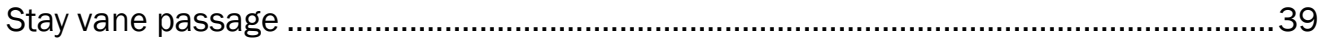

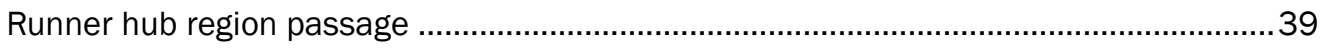

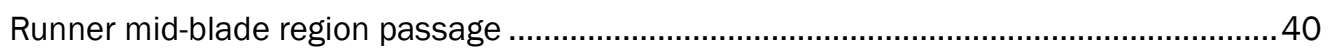

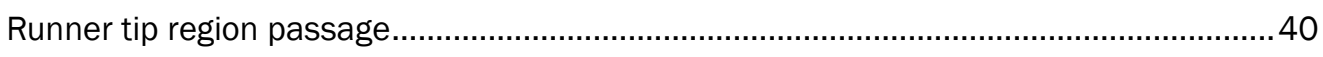

All turbine region combined passage............................................................................... 41

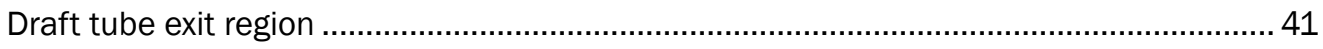

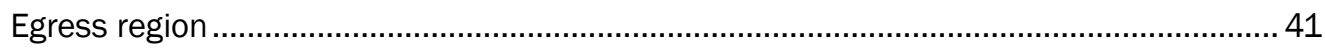

Overall turbine passage conclusion ............................................................................. 41

7 Bonneville Second Powerhouse (B2) Comparison to other U.S. Army Corps of

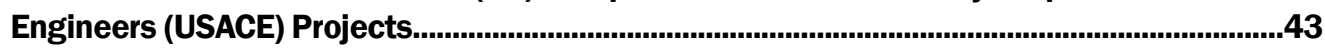

Prototype operational and geometric comparison .........................................................43

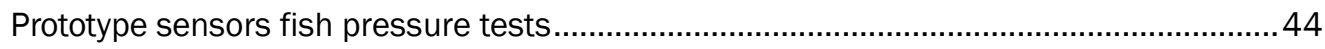

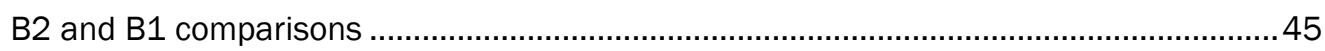

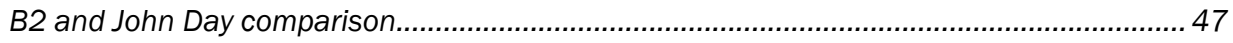

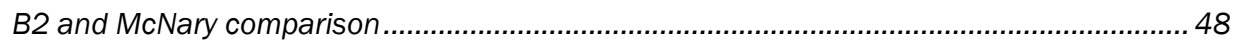

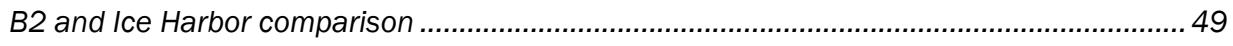

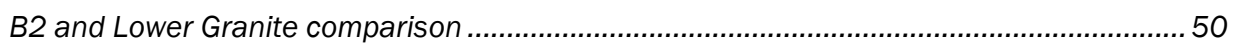

Overall unknowns ................................................................................................... 51

U.S. Army Engineer Research and Development Center (ERDC) data project

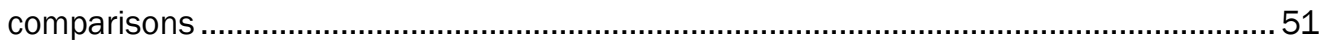

Stay vane evaluation comparisons........................................................................ 52

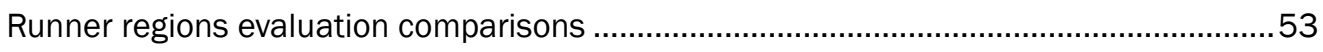

Runner hub region evaluation comparison................................................................... 54

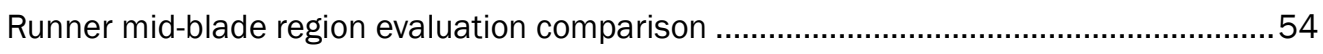

Runner near tip region evaluation comparison .............................................................55

Runner all region combined evaluation comparison.....................................................55

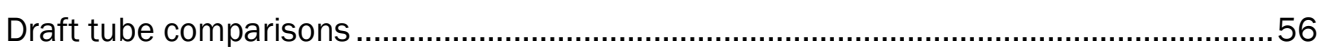

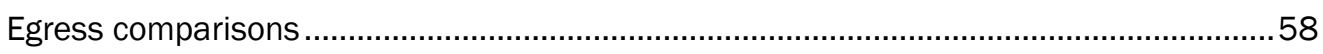

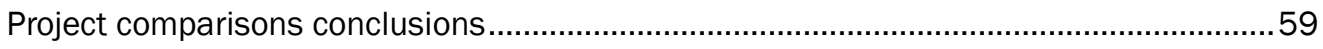

References ..................................................................................................................................61

\section{Plates}

\section{Report Documentation Page}




\section{Figures and Tables}

\section{Figures}

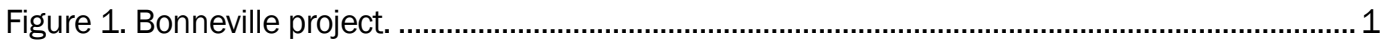

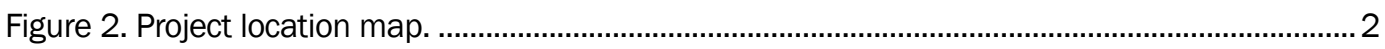

Figure 3. Overall view of model, looking upstream........................................................................ 5

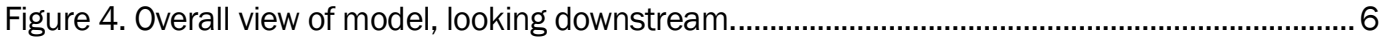

Figure 5. View of model structure and motor. ................................................................................. 6

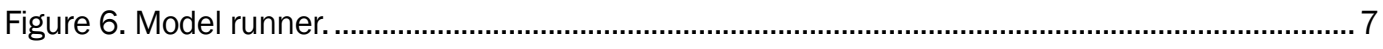

Figure 7. B2 operational CAM graph.......................................................................................13

Figure 8. Wicket gate to stay-vane gap definition...........................................................................

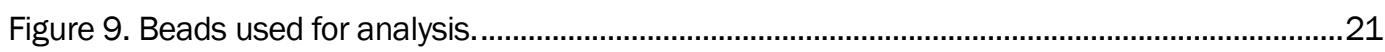

\section{Tables}

Table 1. Equations of hydraulic similitude. ……………...............................................................

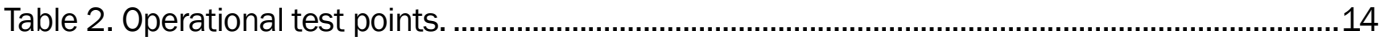

Table 3. ERDC turbine models evaluations by project. ……………...................................................52 


\section{Preface}

This study was conducted for the U.S. Army Corps of Engineers under Turbine Survival Program, Work Unit 157101, "CRFM SYS-S Turbine Bio Index Test.” The technical monitor was Mr. Martin L. Ahmann U.S. Army Engineer District, Walla Walla (NWW).

The work was performed by the Navigation Branch, Fish Passage Group of the Navigation Division (CEERD-HNN-F), U.S. Army Engineer Research and Development Center, Coastal and Hydraulics Laboratory (ERDCCHL). At the time of publication, Mr. Timothy W. Shelton was Chief, CEERD- HNN; Dr. Jacqueline S. Pettway was Chief, CEERD- HN; and Mr. W. Jeff Lillycrop, CEERD- HZT, was the Technical Director for Civil Works. The Acting Director of CHL was Mr. Jeffrey R. Eckstein, and the Acting Deputy Director was Mr. John T. Tucker III.

The experimental program was led by Ms. D. M. Guimbellot-Polk. Mr. Jon Renholds and Mr. Martin Ahmann U.S Army Engineer District, Walla Walla (NWW), and Ms. Laurie Ebner, U.S Army Engineer District, Portland (NWP), performed technical peer review of the report.

NWP performed technical peer review of the report.

During the course of the model study, Messrs. M. Ahmann and J. Renholds, NWW; J. Rerecich, NWP; D. Patla, NWP Hydroelectric Design Center; G. Fredricks and E. Myers, National Marine Fisheries Service; and J. Duombia and S. Bettin, Bonneville Power Administration, visited ERDC to observe model operation, review experimental results, and discuss model results.

The Commander of ERDC was COL Ivan P. Beckman, and the Director was Dr. David W. Pittman. 


\section{Unit Conversion Factors}

\begin{tabular}{|l|l|l|}
\hline Multiply & By & To Obtain \\
\hline cubic feet & 0.02831685 & cubic meters \\
\hline degrees (angle) & 0.01745329 & radians \\
\hline feet & 0.3048 & meters \\
\hline inches & 0.0254 & meters \\
\hline
\end{tabular}




\section{Executive Summary}

The Bonneville Second Powerhouse (B2) turbine model investigations were performed in support of the joint U.S Army Corps of Engineers (USACE), Portland and Walla Walla Districts, Turbine Survival Program (TSP). The TSP was developed to evaluate juvenile fish passage through turbines, with emphasis on identifying turbine structures and operations responsible for fish injury. The first phase (Phase I) of TSP included four main objectives: (1) evaluate and recommend operational criteria to improve the survival of fish passing through Kaplan turbine units, (2) identify the biological design criteria for design of new modifications to the existing turbines, (3) investigate modifications to existing designs that have a potential to increase survival of fish passing through Kaplan turbine units, and (4) recommend a course of action for turbine rehabilitation or replacement that incorporates improvements for safer fish passage.

The USACE 2004 Turbine Survival Program Phase I Report (USACE 2004) identifies turbine passage conditions that may improve juvenile fish survival and suggests the best turbine operating range may not coincide with peak efficiency as previously assumed but may better correlate to an openturbine geometry. The study report recommended additional model investigations be conducted to evaluate the best operating range for juvenile salmonids passing through those turbines within the powerhouses of the eight lower Snake and Columbia Rivers hydropower dams.

The purpose of this B2 turbine model study was to investigate potential risk of injury to juvenile fish passing through all regions of the B2 turbines water passageway, using the existing 1:25 scale physical hydraulic model of the $\mathrm{B} 2$ turbines. Results will be used to help establish a target operating range (TOR) for safer passage of juvenile fish. The study evaluated passage through the stay vane and wicket gate cascade (distributor), the turbine runner, and the draft tube. The study also evaluated retention time within the immediate tailrace region as influenced by draft tube exit conditions.

This report presents results of the B2 turbine model investigations, recommends the best operating range for juvenile fish passage, and provides a discussion as to why the $\mathrm{B} 2$ turbines have a higher survival rate than other turbines within the Lower Snake and Columbia Rivers hydropowerprojects. 


\section{Model investigations}

The model investigations were divided into five study areas. These include the stay vane and wicket gate cascade, the runner, the region immediately below the runner, the exit of each of the two draft tube barrels, and the immediate tailrace region. Model investigations were performed for each of three operating points, at a prototype head of $55 \mathrm{ft}$ (average project head at Bonneville during the juvenile fish outmigration season). The three operating points correspond to (1) a 1\% drop from peak turbine efficiency on the low discharge side (blade angle [BA] of $16.5^{\circ}$ ), (2) peak efficiency $\left(20.3^{\circ} \mathrm{BA}\right)$, and (3) generator limit $\left(26.5^{\circ} \mathrm{BA}\right)$. The upper $1 \%$ limit, which is generally the upper operating limit for turbine operations during the fish passage season (USACE 2011)), was not evaluated for B2 as operation at this point would be beyond the B2 generator limit.

Neutrally buoyant plastic beads were released within the model turbine intake at various locations; their path was documented through the stay vane and wicket gate cascade, runner, draft tube elbow, and tailrace region using highspeed digital cameras. The digital imaging frame rates used ranged from 120 to 1000 frames per second (frames/s) depending on the region being studied. Individual beads were imaged and evaluated for contact with both stationary and rotating surfaces, sudden changes in direction resulting from hydraulic shear and turbulence, and resident time durations in the immediate tailrace region. Laser Doppler velocimeter (LDV) measurements were taken within the draft tube near the exit to evaluate flow distribution and uniformity of flow.

Three regions of the turbine runner were separately evaluated for each of the three operating conditions. These include the near hub region, the mid-blade region, and blade tip region. The percentages of severe blade contacts observed for beads passing near the hub were significantly higher at the flatter BA of $16.5^{\circ}$ compared to those observed at $20.3^{\circ}$ and $26.5^{\circ}$. The same trend was observed for beads exhibiting a severe change in direction while passing through this region. The flatter blade angle of $16.5^{\circ}$ had significantly higher percentages of beads with sudden changes in direction compared to the two steeper blade angles. In addition, hub-toblade gap passage was very high at the $16.5^{\circ}$ compared to the two steeper blade angles with the least occurring at $26.5^{\circ}$.

Overall severe bead contact and sudden changes in direction for the midblade passage were observed to be the least when compared to hub and 
blade tip passage. The number of beads observed to have a severe contact was low for both $20.3^{\circ}$ and $26.5^{\circ}$ BAs but was significantly higher at the $16.5^{\circ} \mathrm{BA}$.

The percentage of beads having severe contact within the blade tip region was highest at the flattest $\mathrm{BA}\left(16.5^{\circ}\right)$ when compared to the $20.3^{\circ}$ and $26.5^{\circ}$; contact for the two steeper blade angles was approximately the same. The beads observed to exhibit severe changes in direction had a trend of reduction as the blade angle was increased. Observations of bead contact (strike) and sudden changes in direction (shear) were the lowest for turbine operations at generator limit followed by peak efficiency. The highest rates of contact and sudden changes in direction occurred at the lower $1 \%$ operating point.

Distribution of flow between the two draft tube barrels was uneven throughout the turbine operating range. The largest disparity between the draft tube barrels occurred at $16.5^{\circ}$ BA. Quality of flow within each draft tube barrel was worst at the $16.5^{\circ} \mathrm{BA}$ and improved with the steeper BAs.

Retention of the beads within the tailrace, or the rate at which beads pass through the tailrace, provide an indication of juvenile fish egress. Higher egress rates would indicate a lower risk of predation. Operating at a $26.5^{\circ}$ BA resulted in lowest passage times indicating improved egress conditions compared to $16.5^{\circ} \mathrm{BA}$. The number of beads entrained into the backroll area was significantly less for the $26.5^{\circ} \mathrm{BA}$ compared to the $16.5^{\circ} \mathrm{BA}$. These results are similar to and consistent with results for other turbine model studies indicating improved egress conditions with higher turbine unit flows (i.e., steeper blade angles).

An analysis of the distribution of beads as they pass through the runner was performed for three operating points to determine where fish are most likely to pass through the stay vane/wicket gate cascade and subsequently the runner. Beads were released at multiple locations within each of the three intake bays. The release locations were within a vertical plane below the tip of the submerged traveling screens (STS) and are assumed to represent passage of fish not intercepted by the STSs. Individual beads were imaged using high-speed digital cameras as they passed through the stay vane and wicket gates and as they exited the turbine runner. The STSs cause large scale turbulence and instability of flow as flow enters the turbine distributor. This resulted in a random and broad distribution of beads entering the stay vane cascade. Beads exiting the runner also 
exhibited a large radial as well as circular distribution for all three operating points.

The highest percentage of beads passed though the mid-blade region, but significant numbers of beads passed through the hub and tip regions. Both hub passage and tip passage routes likely have a significant contribution to the overall mortality of turbine-passed fish.

If screens are removed, the distribution of beads passing through the turbine would shift. A larger proportion of fish would likely pass in the mid-blade and hub region with fewer fish passing through the tip region. It may therefore be even more beneficial to operate turbine runners at a steeper blade angle when operating without screens, as the gap near the hub becomes smaller with steeper blade angles and the risk of injury to juvenile fish passing near the hub is reduced.

\section{B2 comparison to other USACE projects}

A secondary purpose of this study was to compare ERDC B2 model results with other ERDC turbine model study results to determine why juvenile fish passing through the B2 turbines generally have a higher survival rate than fish passing through other turbines within the other Lower Snake and Columbia Rivers Projects.

In comparing the physical attributes of the projects, there are several desirable features of the $\mathrm{B} 2$ turbines: large runner diameter, five-bladed runner, low runner speed, shaped stay vane leading edges, flat draft tube invert exit angle, flat draft tube roof exit angle, deep tailrace, and confined tailrace channel.

Bead interaction with the B2 model turbine stay vane and wicket gates was not significantly different than that of other model turbines evaluated. Bead interaction near the $\mathrm{B} 2$ runner hub is generally worse than that observed of other models, but in general there is no specific aspect of the B2 turbine runner design that performs marginally better than the other model turbine runners evaluated; these include Bonneville First Powerhouse, John Day, McNary, Ice Harbor, and Lower Granite turbines.

Metrics used for the draft tube evaluations for B2 such as draft tube barrel split, draft tube barrel flow intensities, and uniformity of flow were compared to the five other USACE projects (listed above). The B2 runner 
and draft tube configuration did not exhibit an improvement in draft tube flow conditions when compared to the other projects.

Overall egress conditions for B2 appear to be somewhat improved when compared to other projects, and B2 egress performs much better at generator limit.

Key features of the B2 runner that most likely attribute to higher survival include lower flow velocity through the distributor, lower axial flow velocity through the runner, lower tangential velocity of the runner blade (i.e., lower runner speed), and lower velocities through the draft tube.

Although the rate of bead strike and bead direction changes may be similar to the other turbines modeled, the turbulence intensity magnitude of force of strike and shear would be less. Based on sensor fish field data collected from the B2, John Day, McNary, and Ice Harbor Turbine runners, B2 generally exhibits a lower pressure rate of change with higher nadir pressures than other turbine units; this would also attribute to higher fish survival (USACE 2013).

\section{Recommendations}

Results from this model investigation indicate operations with steeper blade angles, resulting in higher unit discharge, create better passage conditions for fish. Fewer severe contacts with the turbine runner and less severe change in direction occur at steeper blade angles. The draft tube performs better at steeper blade angles, and the quality of flow exiting the draft tube is better at steeper blade angles. In addition, model experiments indicate egress conditions may be better at steeper blade angles.

The flattest blade angle of $16.5^{\circ}$ should be avoided during juvenile fish passage season if possible. From this model evaluation, the TOR for fish would be from $20.3^{\circ}$ to $26.5^{\circ} \mathrm{BA}$ with the best operating point being at $26.5^{\circ}$. This is within the current $\mathrm{B} 2$ operational range. Additional turbine pressure information developed through computational fluid dynamics (CFD) or possibly additional field tests may be needed to fine tune the TOR.

Turbine passage pressure effects and project operations are important factors for a full determination of TOR for fish passage but could not be directly addressed in this study. To fully refine the TOR, these two factors should be explored and combined with the results of this model study. 


\section{Introduction}

In 1995, the U.S. Army Corps of Engineers (USACE), Portland and Walla Walla Districts of the Northwest Division, implemented the joint district Turbine Survival Program (TSP). The TSP was established to assess the survival of juvenile salmonids passed through the hydro turbines of the Lower Snake and Columbia Rivers and to evaluate the operations and potential modifications to the turbine units for improved fish passage survival (USACE 2004, 2013).

Eight USACE hydropower projects are being studied by TSP. These include Bonneville (first and second powerhouse), The Dalles, John Day and McNary on the lower Columbia River and Ice Harbor, Lower Monumental, Little Goose, and Lower Granite on the Snake River. These studies include biological field studies, hydraulic observational models, performance models, and computational fluid dynamic models. The TSP recommends the best target operating range (TOR) for the turbines based on results and outcomes from these studies.

\section{Project description}

Bonneville Dam (Figure 1) is located on the Columbia River at river mile 146.1, approximately 40 miles east of Portland, OR (Figure 2).

Figure 1. Bonneville project.

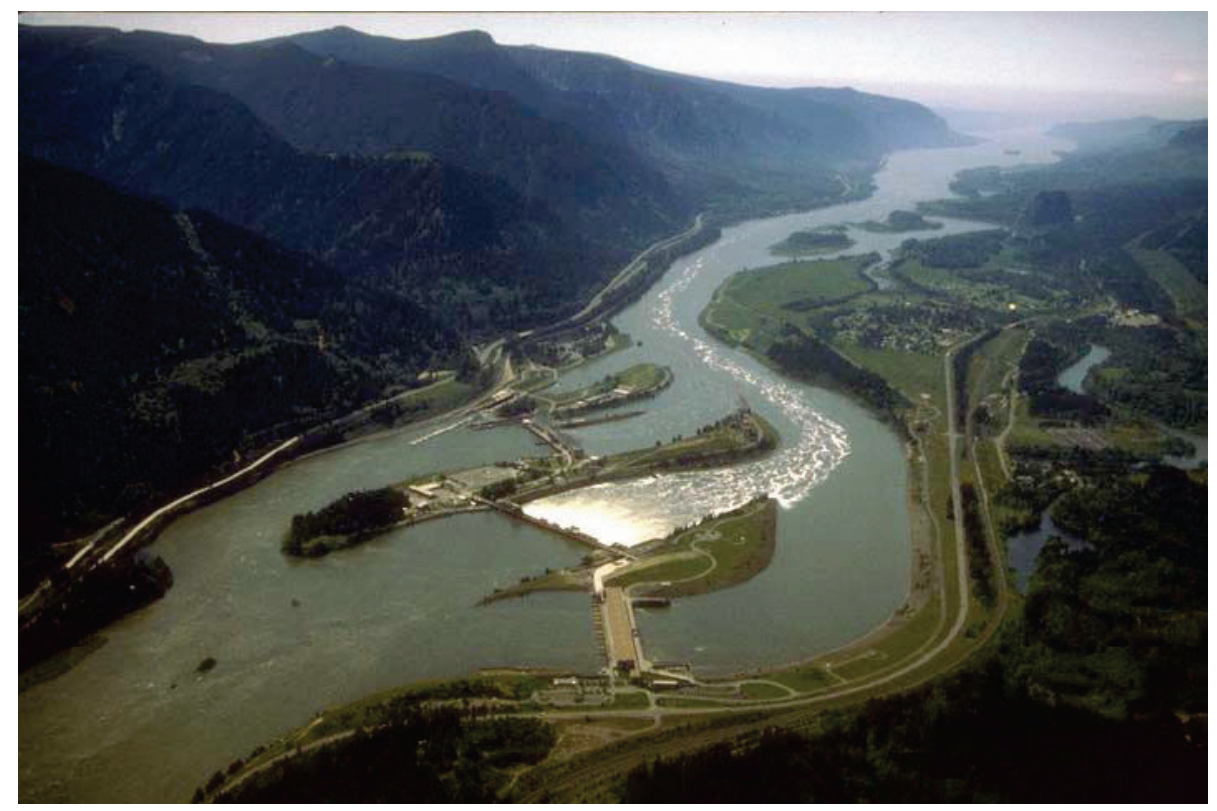


Figure 2. Project location map.

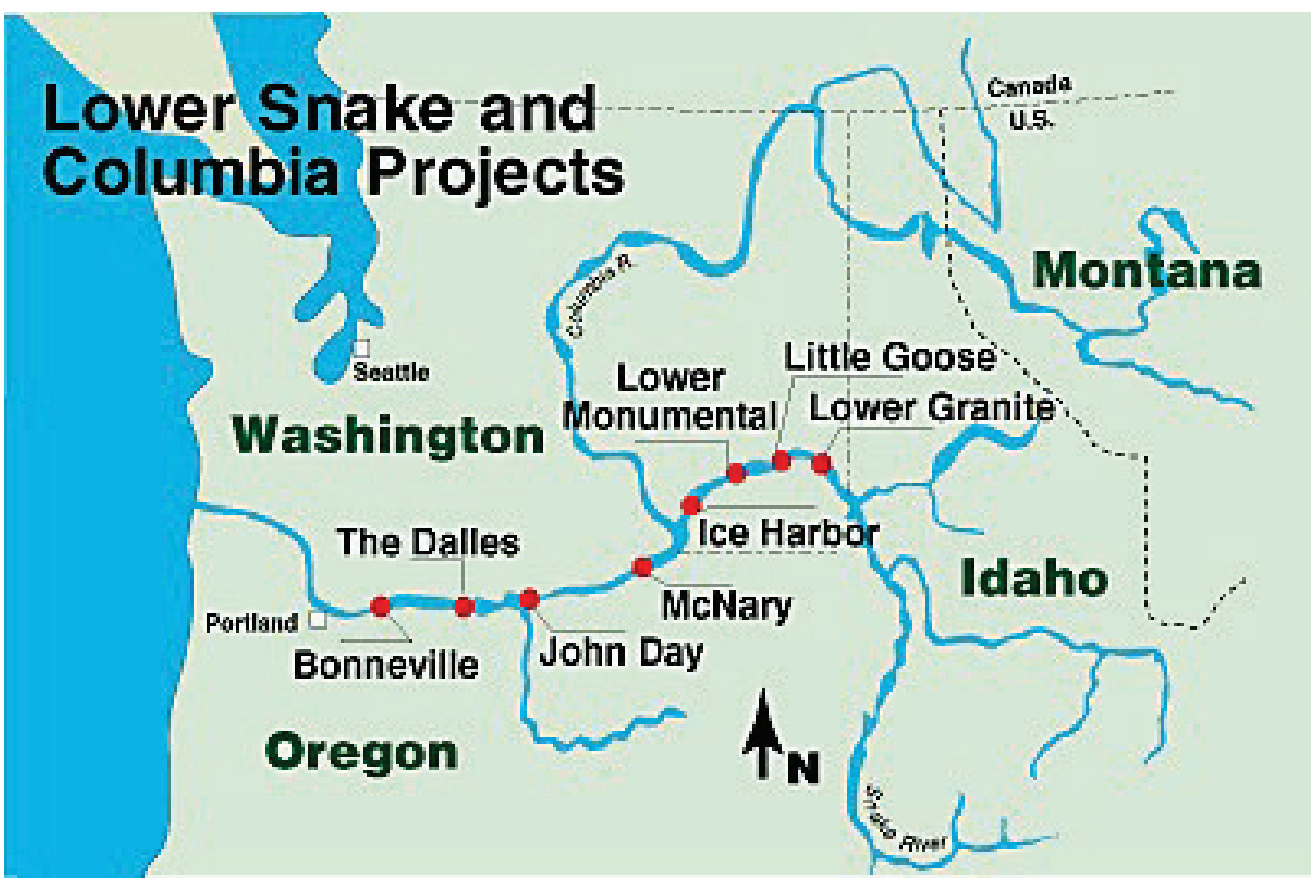

The dam is a multipurpose project that consists of the first and second powerhouses, the old and new navigation locks, and a spillway with a design capacity of 1.6 million cubic feet per second $(\mathrm{ft} 3 / \mathrm{s})$. Construction of the first powerhouse, the old navigation lock, and the spillway began in 1933. President Franklin D. Roosevelt dedicated the lock and dam on 28 September 1937.

The construction of the first powerhouse was completed in 1943. The first powerhouse has 10 units and a flow capacity of approximately $128,000 \mathrm{ft}^{3} / \mathrm{s}$ and a rated power output of 526,700 kilowatts $(\mathrm{kW})$. The original B1 runners were designed and manufactured by S. Morgan Smith. All 10 units at B1 were replaced from 1998 to 2010 by Voith Hydro with minimum gap runners (MGR).

Construction of the second powerhouse began in 1974 and was completed in 1981. The second powerhouse consists of eight units and has a flow capacity of approximately $160,000 \mathrm{ft}^{3} / \mathrm{s}$ and a rated power output of $558,200 \mathrm{~kW}$. These units were designed and installed by Allis-Chalmers. The turbine units are five-bladed Kaplans and rotate at 69.2 rotations per minute (rpm). 


\section{Turbine unit operations}

The prototype turbines on the Lower Columbia River USACE projects are presently operated within $1 \%$ of the overall peak efficiency for any head while juvenile salmon are migrating. This is a requirement of National Oceanic and Atmospheric Administration (NOAA) Fisheries Biological Opinion (BiOp) (NOAA 2000, 2004, 2008). This requirement was set in the 2000 BiOp based on research conducted by Bell and Eicher Associates (Bell et al. 1967; Bell 1981, 1986).

\section{Background}

Presently, all turbines are required to operate within $1 \%$ of peak efficiency at any operating head. Based on direct survival tests conducted at the project and model observations, this may not be the best operating range to minimize the effect of turbines on fish at all projects. Each project should be studied to determine a TOR for minimizing turbine effects on fish and thereby maximizing fish survival. In addition, operating points that should be avoided should be identified as well. There are several things to consider in determining the TOR. Turbine survival is largely dependent on the passage conditions through the powerhouse, overall project operations, and predator abundance downstream of the powerhouse. For turbine passage, direct severe contact with the turbine runner, passing through gaps, passing through high shear zones, and low pressures contribute to direct mortality. Indirect mortality is influenced by the same mechanisms, but in addition, fish experience reduced levels of exposure that result in fish entering the tailrace in a more stressed and disoriented condition. Disoriented and stressed fish in the tailrace may be more susceptible to higher levels of predation as the fish may have greater difficulty in avoiding predators.

A physical model with an operational runner is an excellent tool to investigate the conditions a fish might experience passing through the powerhouse into the tailrace region. This can be conducted in a controlled environment without disruption to project operations or expensive invasive biological evaluations requiring numerous fish. The investigations can be performed throughout the entire operational range of the runner. This includes operational zones outside the current $1 \%$ operating range. These investigations are used to give a relative comparison of different operating points, hydraulic conditions, and their potential impact on direct and indirect mortality. Every path that a fish may take through the 
intake, wicket gates, turbine runner, draft tube, and the influence of the passage environment on egress can beevaluated.

\section{Objective}

The purpose of this study was to thoroughly investigate all potential passage routes through the powerhouse main units to assist in determining the TOR for improving fish passage conditions at the B2. Relative effects of blade contact, shear, stay vane and wicket passage, draft tube conditions, and effects on egress were determined across the entire turbine operational range at $55 \mathrm{ft}$ head. Turbine passage pressure effects and project operations are important factors for a full determination of TOR for fish passage but cannot be directly addressed in this study. A secondary purpose was to compare B2 results with other ERDC turbine study results to access why B2 appears to have higher survival than other turbine units.

\section{Approach}

A physical model was used to fully investigate passage routes through the areas of the powerhouse intake structure where direct fish injury or mortality might occur. This included the stay vane and wicket gate cascade, the turbine runner, and draft tube elbow and draft tube passageway. In addition, the effect of turbine passage on egress conditions in the tailrace was also investigated.

These investigations were conducted throughout the turbine operating range utilizing turbine investigation techniques and methods developed at the U.S. Army Engineer Research and Development Center (ERDC). Analysis of results from these investigations allowed for a recommendation of a TOR based on mechanisms contributing to direct injury as well as indirect injury and mortality occurring downstream of powerhouse related to turbine passage. There are others factors that could affect TOR that have to be considered that cannot be addressed or determined from this model study, such as pressures through the turbine, depth acclimation of migrating smolts, predator loading at the B2 powerhouse, and distribution of smolts entering the powerhouse intake structure. 


\section{Physical Model}

\section{Turbine model description}

The Portland District supplied as-built drawings of the B2 structure and screens. Pertinent information needed for model design and construction was taken from these drawings and transferred into a computer-aided design program.

A new 1:25 scale model of a B2 turbine was constructed at ERDC in 2006 and 2007. This model is a geometric replicate of a single powerhouse unit including three intake flow bays, scroll case, stay vane and wicket gate cascade, draft tube, trashracks, screening devices, and vertical barrier screens. The model also replicates approximately $650 \mathrm{ft}$ of approach topography and $325 \mathrm{ft}$ of downstream tailrace topography. The bathymetry upstream and downstream of the prototype powerhouse varies across the powerhouse, so the model topography is an average of expected topographies and is representative of what exists at the prototype. The model was constructed of acrylic to allow visual observations, turbine evaluation for fish, and hydraulic investigations through the entire structure. Photographs of the new model are provided in Figures $3-5$.

Figure 3. Overall view of model, looking upstream.

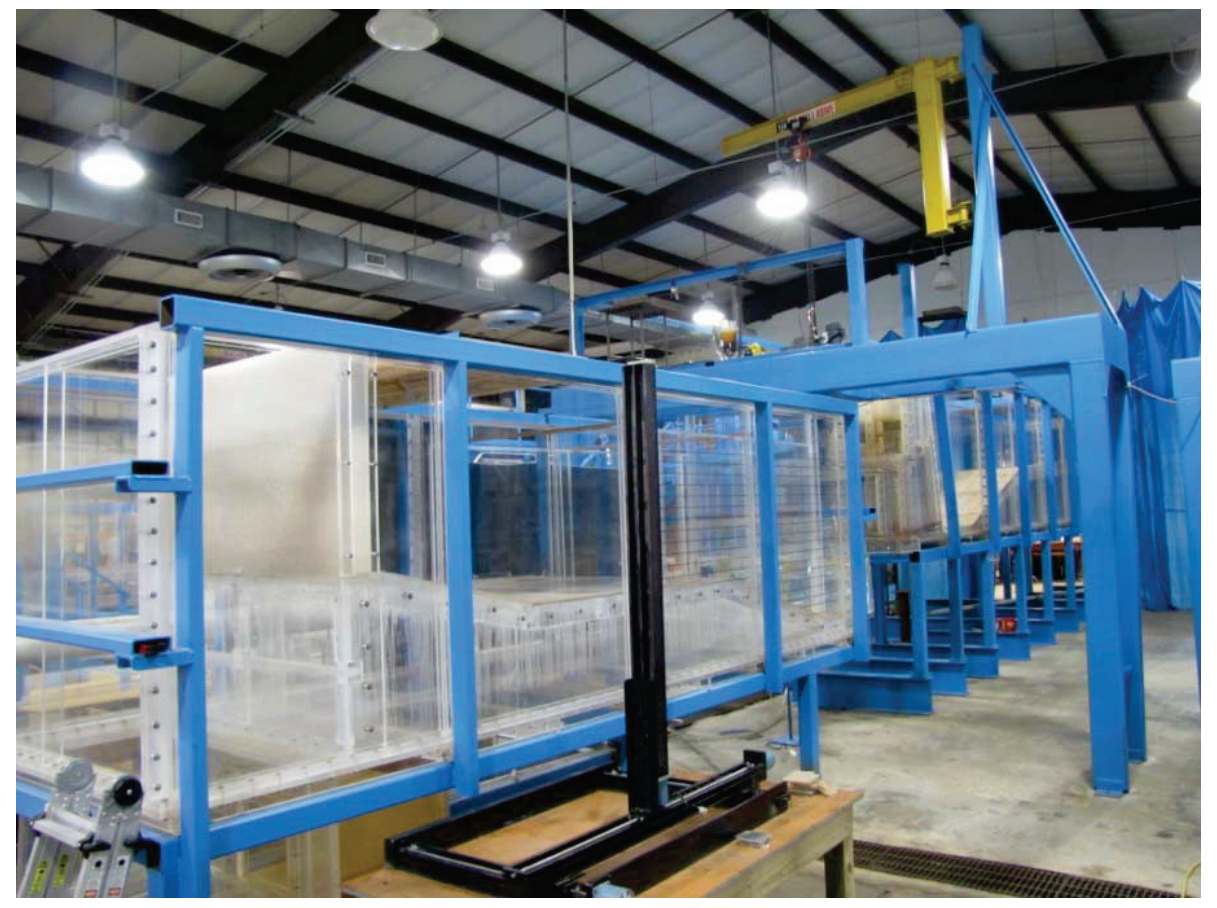


Figure 4. Overall view of model, looking downstream.

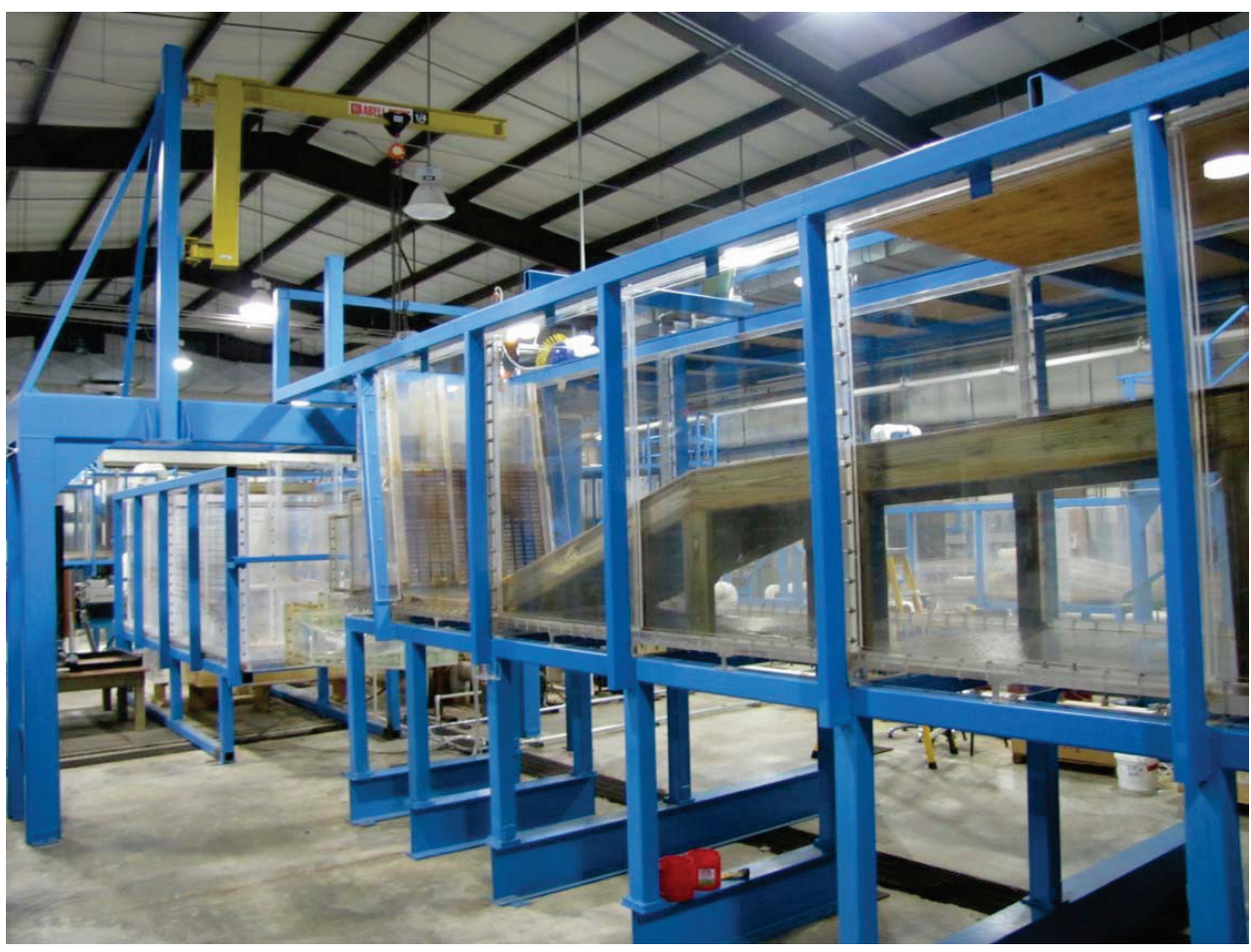

Figure 5. View of model structure and motor.

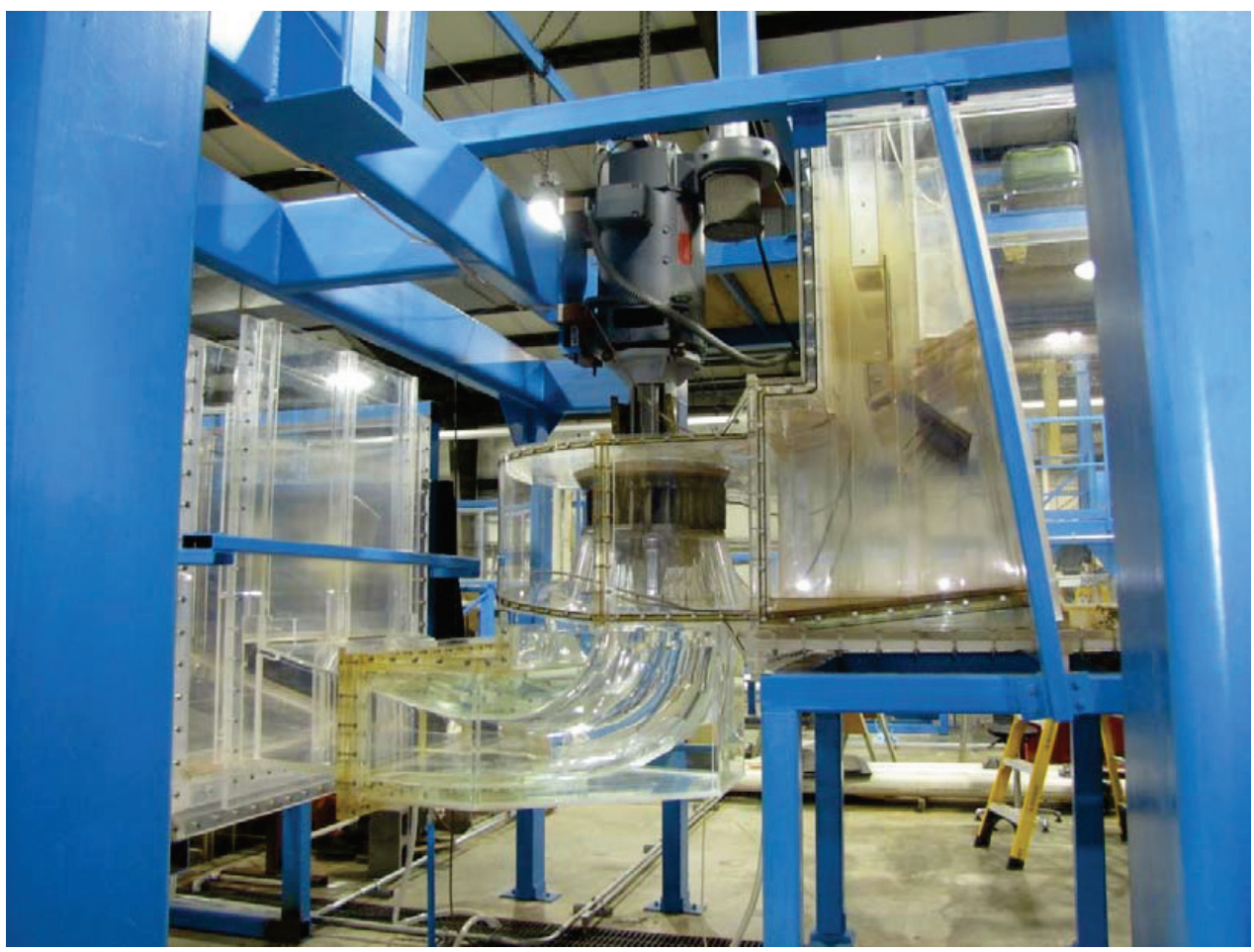


A five-bladed turbine runner was constructed by Voith Siemens in 2007 and delivered to ERDC. The ERDC model was constructed to accommodate this turbine runner. Figure 6 shows the model runner.

Figure 6. Model runner.

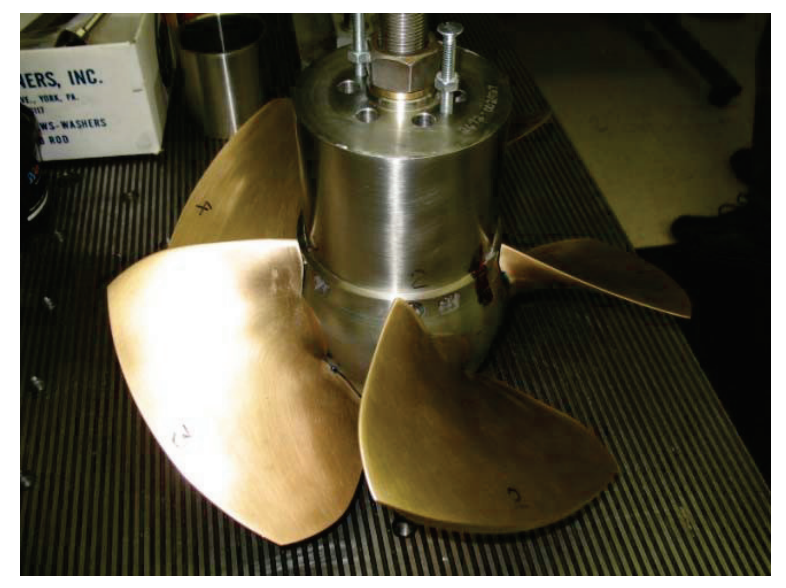

The hydraulic design, the operating performance including power, efficiency, cavitation limits, and operating curves were developed using a high-head turbine performance model. Performance models have very limited visual access to the intake structure, turbine runner area, draft tube, and the tailrace area. In addition, the experiments in the performance model are conducted at high heads, normally $50 \%$ to $70 \%$ of prototype head. This is done to increase the model Reynolds number to allow more accurate head, discharge, and torque measurements. These measurements are required to accurately determine model turbine efficiency. Because of the high-head model test requirements, the performance models are generally constructed of steel, with the exception of an acrylic discharge ring. This steel construction limits the ability to observe and investigate the entire hydraulic passage.

The experiments in the ERDC turbine model were conducted at Froude head (1 to 25). This allows for the entire model to be constructed from acrylic (except for trashracks, fish screens, stay vanes, wicket gates, and runner). Accurate hydraulic investigations can be performed anywhere in the flow field. This includes the forebay, intake structure (approach to turbine), stay vane cascade, turbine environment, draft tube, and downstream of the draft exit. Torque is not measured in ERDC turbine models due to the high friction between the runner shaft and runner seals. Therefore, efficiency cannot be determined from this model. The operational parameters utilized for the ERDC cam curves are developed in 
the performance model combined with information obtained from the prototype turbine during field index testing. Cam curves define the runner blade setting and wicket gate setting at a given project head for a desired power or dicharge output.

Froude modeling more accurately scales screening devices that are used for fish diversion within the intake structure as well as conditions in the draft tube into the tailrace.

\section{Model calibration}

Calibration of the B2 turbine model requires calibration of the water supply system and the turbine runner control system including control of the wicket gate angle, the runner blade angle, and runner speed. Operation and setting of the model blade angle, gate position, and runner speed are most critical. They are the most well-defined and primary operating parameters of the prototype. Because discharge is the least accurate prototype measurement, once the model blade angle, gate position, and runner speed are set, the model discharge can be adjusted as needed to maintain any given project head. An accurate measurement of model discharge can be helpful in assuring that the model turbine runner is operating properly and that the proper prototype cam curves are used in establishing the model test conditions. Cam curves are plots of efficiency versus power or discharge and define the most efficient turbine operating point for a given head for a desired power or discharge output. Discharge information supplied to ERDC for model operation is a calculated value from other measured prototype values such as power and head. Once the model blade angle and wicket gate are set according to the prototype cam curves and the desired project head is reached, the model discharge (which is accurately measured and controlled in the model) should agree with the prototype predicted discharge within $4 \%$. Historically, they normally are within $3 \%$ of each other. Prototype turbine discharge is the least accurate operating parameter supplied to ERDC for model operation. Often the prototype calculated discharge does not match the model discharge determined values for the supplied CAM. This results in extended periods of investigations by ERDC and Hydroelectric Design Center (HDC) to determine more accurate prototype target discharges. 


\section{Inflow meter calibration}

Water is supplied to the model by three pumps. Each pump is capable of supplying $9,375 \mathrm{ft}^{3} / \mathrm{s}$ prototype or $3 \mathrm{ft}^{3} / \mathrm{s}$ model scale. This provides a total inflow capacity of approximately $28,125, \mathrm{ft}^{3} / \mathrm{s}$ (prototype), which exceeds the maximum discharge expected at $\mathrm{B} 2$ of $20,000 \mathrm{ft} 3 / \mathrm{s}$. A Data Industrial flow meter was placed in each inflow supply line to measure the inflow rate. Each flow meter was calibrated in the Coastal and Hydraulics Laboratory Volumetric Calibration Flume before it was installed.

Calibration is accomplished by introducing a desired flow into the calibration flume and recording the amount of time needed to fill a known volume. The flow rate is calculated by dividing the flume volume by the time required to fill the flume. This procedure is repeated, and the two values are averaged. The resulting value becomes the established flow rate. During the above procedure, the flow is measured by a Data Industrial flow meter, and this value is recorded. This procedure is repeated for several different inflows. The established flow rates are then plotted against the corresponding Data Industrial-measured values, and a correction factor is applied to the Data Industrial flow meter to give the correct discharge value. Flow calibration curves for the two flow meters are provided in Plates $1-3$.

The final calibration curves allow for setting the desired model discharge with an accuracy of $1.0 \%$. The R-squared values for each calibration curve varied between 0.9998 and 0.9989 , which proves a very good fit for the calibration data. Calibrations are checked yearly or before a new testing program begins.

\section{Wicket gate calibration}

A regulating ring with graduated marks controls the wicket gate opening. The regulating ring setting-to-wicket gate opening is calibrated by setting the regulating ring to a specified mark and then measuring the channel opening between each pair of wicket gates. The wicket gate channel openings for all channels are averaged and plotted against the regulating ring mark number. This process is repeated incrementally until the full operating range is covered. This information is used to develop a calibration curve for wicket openings vs. regulating mark numbers. This calibration curve is provided in Plate 4. 
The final calibration allows for setting the wicket gate opening within $1.1 \%$ of the desired opening. The R-squared value for the calibration curve was 0.999, which proves a very good correlation for the calibration data. The sensitivity of the model regulating ring allows for setting the wicket gate opening to within 0.33 inch (in.) prototype or 0.013 in. model scale. The wicket gate angle range for the $\mathrm{B} 2$ model is $\mathrm{O}^{\circ}$ to $57.0^{\circ}$. The accuracy permitted by the regulating ring is $+/-0.5^{\circ}$, which is a maximum error of $1.5 \%$ over the expected operating range.

\section{Runner speed calibration}

The rotational speed of the turbine runner is controlled by a direct current motor/generator. The speed of the model runner was $346 \mathrm{rpm}$. The speed of the runner is verified by a strobe light to ensure the motor speed output is correct. The strobe light emits a pulse of light at a wide range of frequencies, which encompasses the runner speed, with a precision of $0.1 \%$.

\section{Blade angle calibration}

Voith Siemens supplied the model runner. The B2 model runner can vary between BAs of $16.5^{\circ}$ and $30^{\circ}$. Changing the displacement rod connected to lever arms within the model hub of each runner sets the blade angle. The method Voith Siemens uses for setting the blade angle in its performance model is based on measurements made on the pressure side of the blade in a calibration cradle. Since the runner would have to be removed to perform this calibration, it is not a usable method for the runners in the ERDC model.

Voith Siemens scribed two marks on the runner hub and runner blade trunnions. The marks corresponded to two known BAs. The rod displacement was measured for each of the BAs. To check calibration of the blades in the ERDC model, the marks on the trunnion and the runner hub are matched, and the rod displacement is measured and compared to the Voith Siemens-calibrated measurements. If the marks match, then the runner blades are still calibrated. They have matched each time they have been checked. Voith Siemens calibrated each runner and supplied ERDC with the curves.

ERDC added additional scribe marks to the hub to allow for calibration points between marks provided by Voith Siemens. The final calibration allows for setting the blade angle to within $0.3 \%$ of the desired angle. The 
R-squared value for the calibration curve was 0.999, which is a very good fit for the calibration data. The calibration curve used during ERDC model experiments is provided in Plate 5.

\section{Model similitude}

Equations of hydraulic similitude, based on the Froudian relations, are used to express mathematical relations between the dimensions and hydraulic quantities of the model and the prototype. General relations for the transfer of model data to prototype equivalents, or vice versa, are presented in Table 1.

Table 1. Equations of hydraulic similitude.

\begin{tabular}{|c|c|c|}
\hline Dimension & Ratio & $\begin{array}{c}\text { Model:Prototype Scale } \\
\text { Relations }\end{array}$ \\
\hline Head & $\mathrm{Lr}=\mathrm{L}$ & $1: 25$ \\
\hline Length & $\mathrm{Lr}=\mathrm{L}$ & $1: 25$ \\
\hline Area & $\mathrm{Ar}=\mathrm{Lr}^{2}$ & $1: 625$ \\
\hline Velocity & $\mathrm{Vr}=\mathrm{Lr}^{1 / 2}$ & $1: 5$ \\
\hline Time & $\mathrm{Tr}=\mathrm{Lr}^{1 / 2}$ & $1: 5$ \\
\hline Discharge & $\mathrm{Qr}=\mathrm{Lr}^{21 / 2}$ & $1: 3125$ \\
\hline Runner speed & $\mathrm{Nr}=1 / \mathrm{Lr}^{1 / 2}$ & $1: 0.2$ \\
\hline
\end{tabular}

Even through the ERDC model is operated according to Froude similitude, Reynolds number similitude is also maintained in the ERDC model within the intake structure, turbine environment, and draft tube. The difference between performance models (Reynolds similitude) and ERDC turbine models is that the Reynolds number is higher in the performance model to minimize frictional resistance. This allows for more accurate determination of model efficiency. Since friction resistance is a very small component for turbine passage hydraulics (with the exception of the power produced), operating the ERDC model at lower Reynolds numbers (still fully turbulent flow) has little effect on the accuracy of the modeling.

\section{Model operation procedure}

The ERDC B2 turbine model is set up by the following procedure. A desired blade angle and wicket gate angle are set, and the inflow discharge is controlled to a desired value. The water elevation in the flume downstream of the draft tube is controlled by a number of vertical wicket gates operated in parallel. When the desired tailrace water elevation is set, the discharge is 
adjusted until the upstream water surface reaches its desired elevation. The discharge, blade angle, headwater elevation, and tailwater elevation will match prototype values. The model discharge is the only variable that does not exactly match the prototype. Note that measurement of discharge through the prototype unit is very difficult. The discharge provided to ERDC for setting the model is a calculated value and thus is not a highly accurate value but is based on both performance model and field-test data. This value has the most uncertainty of any input variable. During the testing of the B2 model, all measured discharges were within $5 \%$, and most were within $3 \%$ of predicted prototype discharge. Also, it is not possible to match every variable because of differences in Reynolds number and roughness between the model and the prototype structures. The blade-to-wicket gate relationship is the same for a given head for the ERDC model and prototype turbines. Therefore, the difference in discharge for an on-CAM point should not affect ERDC model results.

This should be true as long as the turbines are operated using a correct CAM.

Operational information such as the blade angle, discharge, and wicket opening for 55 and $60 \mathrm{ft}$ of head was supplied by HDC and is based on prototype index tests and high-head model tests (Figure 7). 
Figure 7. B2 operational CAM graph.

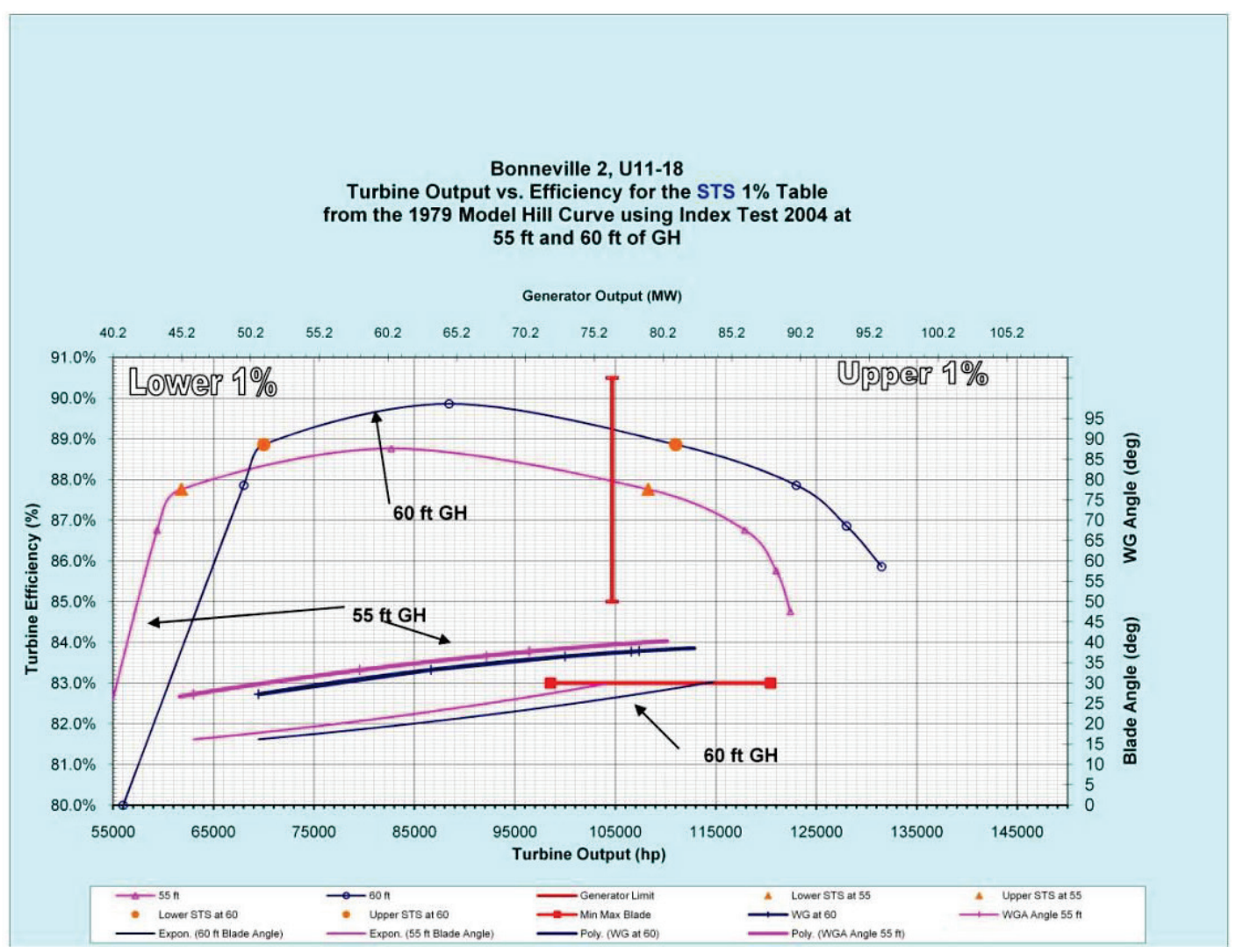




\section{Model Experiments Approach}

\section{Model test conditions and investigations}

The model investigations were performed for three operating points. These operating points corresponded to the lower $1 \%$, peak efficiency, and generator limit at $55 \mathrm{ft}$ of head. At $55 \mathrm{ft}$ of head, the upper $1 \%$ occurs above generator limit. Operating conditions at $55 \mathrm{ft}$ of head were chosen since it is approximately the average head during the bulk of the fish passage season in spring and early summer. At the time of this study, the units were required to operate within $1 \%$ efficiency (off ofpeak efficiency). STS (20 ft long) were installed for all experiments. For $55 \mathrm{ft}$ of head, the forebay was at $72.5 \mathrm{ft}$ mean sea level fmsl, and tailwater was at $17.5 \mathrm{fmsl}$ (prototype). The operating parameters supplied by HDC for the model tests are provided in Table 2.

Table 2. Operational test points.

\begin{tabular}{|c|c|c|c|c|}
\hline Operating Point & $\begin{array}{c}\text { Blade Angle } \\
\text { (deg) }\end{array}$ & $\begin{array}{c}\text { Wicket Gate } \\
\text { Rotation } \\
\text { (deg) }\end{array}$ & $\begin{array}{c}\text { Head } \\
\text { (ft) }\end{array}$ & $\begin{array}{c}\text { Target } \\
\text { Discharge } \\
\left(\mathrm{ft}^{3} / \mathbf{s}\right)\end{array}$ \\
\hline $\begin{array}{c}\text { Lower 1\% } \\
\text { (L1\%) }\end{array}$ & 16.5 & 33.1 & 55 & 11,280 \\
\hline Peak & 20.3 & 39.1 & 55 & 14,925 \\
\hline $\begin{array}{c}\text { Generator } \\
\text { Limit (GenL) }\end{array}$ & 26.5 & 45.9 & 55 & 19,115 \\
\hline $\begin{array}{c}\text { Upper 1\% } \\
\text { (U1\%) }\end{array}$ & 27.9 & 47 & 55 & 19,758 \\
\hline
\end{tabular}

All physical hydraulic model investigations were conducted with the $20 \mathrm{ft}$ STS installed. At the time of this study, the STSs are installed during fish passage season. The investigations included bead analysis and draft tube velocity measurements. The model was also qualitatively examined with dye. The bead analysis consisted of analyzing high-speed digital imaging of small, neutrally buoyant plastic beads released into the flow path. The digital video was evaluated to determine the exposure of those beads to high shears zones, the potential for those beads to impact structure, and defining egress metrics downstream of the draft tube exit. LDV measurements were obtained to define the characteristics of flow within the turbine draft tube barrels. 


\section{Study areas}

The model experiments were divided into four parts or study areas identified by region in Plate 6. Part I was to release beads into each intake bay at the screen slot and to capture their passage path though the stay vane and wicket gate cascade with high-speed video and then document and analyze each bead for surface contact and sudden changes in direction. Part II was to release beads between stay vane pairs to pass beads through the three zones of the runner (near hub, mid-blade, and near blade tip) for each operating point. The beads paths were imaged with high-speed digital cameras to determine the rate at which beads impact structure and/or experience sudden changes in direction. Part III was to assess turbine operation effect on egress by releasing beads into the intake and imaging them as they exited the draft tube. Part IV was to obtain velocities in the draft tube (near its exit) to determine the quality of draft tube flow.

\section{Stay vane cascade evaluation}

Beads were released in each of the intake bays at various elevations and lateral locations (Plate 7). Their passage through the stay vane cascade was imaged with three high-speed digital cameras at a frame rate of 500 frames/s. A schematic of the stay vane cascade arrangement is shown in Plate 8. Numerous release locations within each intake bay were required to pass beads through the entire stay vane cascade. Each bead was graded for surface contact, sudden change in direction, and for stay vane-to-wicket gate gap passage (Figure 8). This analysis was performed for three operating points. Stay vane testing was completed before the scope of the ERDC evaluation was changed to include two additional operating points. 
Figure 8. Wicket gate to stay-vane gap definition.

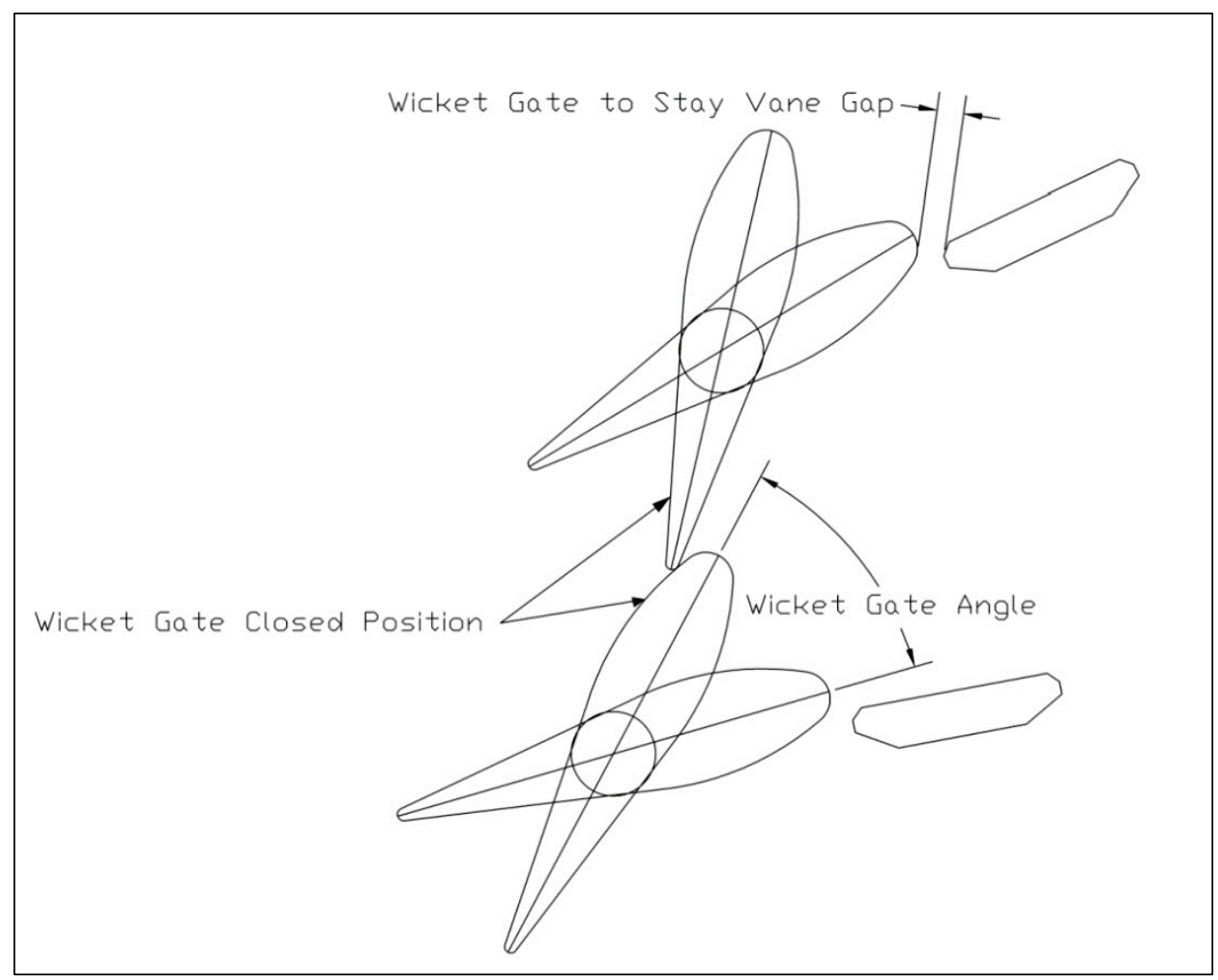

\section{Turbine runner evaluation}

Beads were released at the stay vanes to evaluate the impact of the runner. Specific release locations were chosen such that groups of beads would pass through three defined runner zones: near the runner hub, the midblade region, and near the blade tip. Release tubes were secured to the stay vanes (e.g., near top of the stay vane for hub passage) to ensure consistent release point during bead analysis. Between 450 and 650 beads were released for each of the three runner zones. Beads passing through the runner were imaged using three high-speed cameras at frame rate of 1,000 frames/s. One camera was set to image the leading edge of the blade, a second camera to image the pressure and suction side of the blade profile, and the third camera to image the bottom of the blades. All three cameras were time sequenced to each other to ensure that during analysis each bead could be identified and evaluated from each camera.

The distribution of fish passing through the prototype runner is unknown and most likely varies with differences in seasonal and diel patterns.

Therefore, each passage zone is analyzed independently so that the risk in each passage route can be defined. Then all passage routes are combined 
into one data set (at each operating point), and an analysis of all passage routes together is performed.

This treats all areas of the turbine equally as potential passage routes.

Assumptions could be made that for fish that pass under the screens, more fish would pass near mid-blade zones compared to the tip passage zone. This is because fish that pass through the top of the intake would be screened out, and the majority of the remaining fish would pass middle to bottom of the distributor (if they followed flow lines). However, since fish behavior within the intake and the distribution of fish entering the intake are unknown, no passage zones can be excluded from the potential fish passage route. In addition, turbulence that is caused by the STS results in a vertical redistribution of beads (fish) approaching the stay vane cascade.

\section{Egress bead evaluation}

Neutrally buoyant beads were released into each turbine intake bay at three lateral positions per intake bay (Plate 8); multiple release locations were used to give a broad distribution of beads and would be representative of fish having a wide vertical and lateral distribution as they pass through the intake structure. The beads were imaged with three cameras (120 frames/s rate) as they exited the draft tube barrels and traveled to a location downstream of the influence of the turbine boil (175 prototype $\mathrm{ft}$ ). The general flow path and time of passage was documented. Other parameters, such as entrainment within the backroll and exposure to near surface elevations, were also documented. 


\section{Model Evaluation Techniques}

\section{Data acquisition with laser Doppler velocity (LDV) meter}

A four-beam, two-color LDV was used to measure draft tube velocities. This system consisted of a 4-watt Argon laser, optics to split and color separate the laser beam according to precise frequencies of light, fiber optics to carry the light to the model, a fiber probe with a $23.6 \mathrm{in}$. focal length, and signal processors for analyzing the signal from the fiber probe. A computer-controlled traversing system precisely controlled the position of the fiber probe for each velocity measurement. This system measured two components of the flow field within a plane perpendicular to the light beam. The LDV system is a critical non-invasive tool for defining flow distributions, velocity magnitudes and direction, turbulence, and investigations of hydraulic shear.

Velocities were measured at two cross sections in each draft tube barrel. Only the most downstream section is reported. The upstream cross section is used as a quality control for the reported cross section. The calculated discharge between the upstream and downstream sections should agree within $2 \%$. The reported cross section is 12 prototype $\mathrm{ft}$ upstream of the draft tube exit. Plate 10 details the measurement locations. This cross section is in the draft tube as physically close to the draft tube exit where a complete cross section of velocities can be obtained. This is so that the effects of the draft tube exit flow characteristics on egress conditions can be determined.

The velocity data were used to document the flow split between the two draft tube barrels as well as provide a barrel turbulence intensity value for each barrel and the uniformity of flow within and exiting each draft tube barrel. They are defined as

Draft Tube Turbulence Intensity $=\frac{\text { Average Section Standard Deviation of Velocities }}{\text { Average Section Mean Velocity }}=* 100$

$$
\text { Draft Uniformity }=\frac{\text { Standard Deviation of SectionVelocities }}{\text { Average Section MeanVelocity }}=* 100
$$


This information is used to indicate where it would better to operate the turbine to provide better quality of flow within the draft tube. A higher level of turbulence and shear in the draft tube increases the potential for fish to become disoriented and is likely to increase stress levels in the fish. Both of these metrics potentially have a negative effect on indirect survival rates. In addition, the more uniform the flow exiting the draft tube, the more turbulence is reduced and the better the chance the fish will be released into the tailrace with an overall positive downstream movement. In addition, reverse flow (upstream direction) in the draft tube is undesirable and not optimal for the most benign passage experience.

\section{Data acquisition and analysis with neutrally buoyant beads}

A high-speed digital camera system was used to image neutrally buoyant beads as they passed through the stay vanes, wicket gate cascade, runner region, and draft tube elbow. This system consists of four monochrome cameras set up to capture images of bead passage at a frame rate of up to 1000 frames/s with a resolution of 1024 pixels. Because of file size, the maximum film duration is limited to $6 \mathrm{~s}$. Each $6 \mathrm{~s}$ segment will capture the passage of 25 to 50 beads depending on passage route, visible access, and the analysis to be conducted. The image segments are stored in an audiovideo interleaved (AVI) format.

Beads passing through the stay vane, wicket gates, runner, and draft tube elbow were individually evaluated to identify rate and severity of contacts with surfaces in the flow field. A surface contact grading system was established as follows:

1. Very Severe (direct, hard contact causing a severe change in direction)

2. Severe (direct contact with change in direction)

3. Moderate Strike (contact with moderate change indirection)

4. Glancing Strike (makes light contact with surface with little change in direction)

5. Touching (bead travels with slight bump of surface or sliding along surface)

6. No contact with any surface.

The beads were also individually evaluated for abrupt changes in direction, which might indicate areas of high shear. The grading system for bead change in direction was as follows: 
1. Severe sudden change in direction

2. Moderate sudden change in direction

3. Small change in direction

4. No significant change in direction.

After grading each bead, the contact scores and change-in-direction scores were averaged to obtain an overall score. The percentages of severe contacts (those with a score of 1 and 2) and severe direction changes (those with a score of 1 and 2) were also calculated. The grading of the beads was performed manually by the same technician.

In addition to the contact and change-in-direction score, a product score is also calculated for each bead. The product score is obtained by multiplying the contact score by the change-in-direction score. The product score gives an overall grade for comparing different passage routes as well as different turbine operation points. Once the product score has been obtained for each test bead, all the product scores are summed, and the average of the sum is the overall product score for a particular release.

Beads are not fish and do not behave or react to a stimulus in the flow field. However, fish passing through the stay vane cascade entrance would experience velocities that exceed sustained swim speeds of juvenile salmon (Bell 1986). They would have little control to no control when passing into the runner region where velocities are so high that fish would have no choice but to go with the flow. Beads are excellent tools to indicate and predict contact and/or shear impacts fish might experience passing through these areas. Also, beads are excellent tools to compare one turbine operation to another (relative comparison). The beads are approximately cylindrical in shape, which allows bead rotation to be observed. The length of the beads is $4 \mathrm{in}$. (prototype scale), which is close to the length of a juvenile salmon. Figure 9 show beads used in the analysis. 
Figure 9. Beads used for analysis.

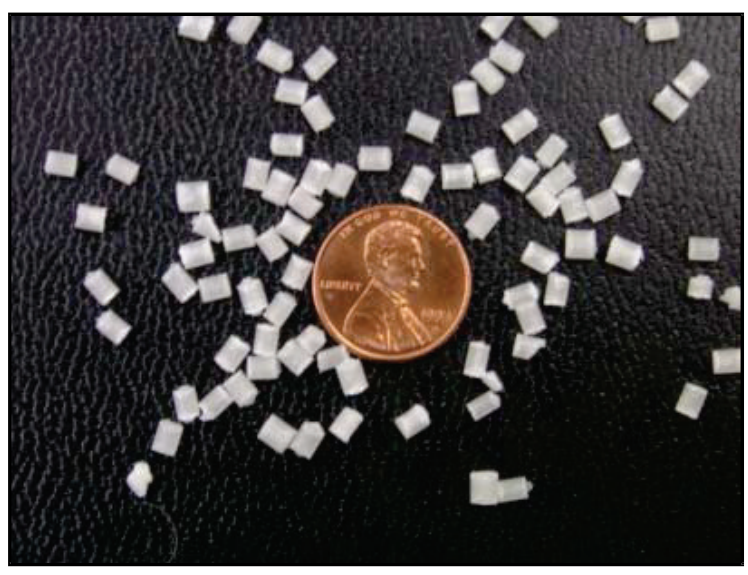

Fish mortality for turbine-passed fish is comprised of two parts: direct mortality and indirect mortality. Direct mortality is attributed to several mechanisms.

Direct morality is mainly the result of fish contact with the turbine runner, passing through gaps in the stay vane cascade, runner blade gap passage, high area of shear, and low-pressure areas within the turbine environment.

Indirect mortality results mainly from predation downstream of the powerhouse. It is directly influenced by passage through the stay vane cascade, runner passage, draft tube conditions, and where and how the fish are introduced into the tailrace area. It is also influenced by predator abundance, environmental conditions, and project operations.

Bead experiments that evaluate stay vane passage, runner passage, draft quality of flow, and egress investigations allow for the comparison of all passage areas across the entire turbine operational zone. It relatively compares severe contacts and severe changes in direction (high shear), which indicates where it should be better to operate the turbine to minimize risk of direct mortality. However, it also indicates where it is better to operate the turbine to reduce potential stress, disorientation of fish, non-lethal impacts, and changes in direction so that the fish are delivered into the tailrace with a better ability to avoid predation. This is not to say that this will eliminate downstream predation, but it should be possible to reduce the downstream predation by operating the turbines as described above. These physical model results should help identify the optimal operation range and hydraulic conditions to minimize the 
potential for strike, shear, and downstream predation applicable to both direct and indirect mortality.

\section{Test bead sample size}

The initial bead sample size determination was based upon the methods used by Normandeau Associates Inc. (2000) for its direct survival tests.

A report entitled Characterization of Sampling Precision and Sample Size Requirements for Bead Strike Trials was prepared for ERDC by Dr. John R. Skalski in 2006 (Skalski 2006). This report is documented in ERDC report "Bonneville First Powerhouse Operating Range Investigations" (Davidson 2017) and details the methods used by ERDC to determine sample sizes for all bead evaluations. This method is similar to the methods used in direct-survival balloon tag studies for determining sample size.

Control releases of beads are not required for ERDC experiments, as all beads released are accounted for. The target precision level is between precision level $(\varepsilon)$ of $\leq+0.03 \%$ and $\leq+0.02 \%, 95 \%$ of the time. For the runner evaluation, ERDC uses an expected probability of $12 \%$ of encountering a strike or shear event (based on previous bead studies). A precision level of $2.5 \%$ would require approximately 65 o beads.

For stay vane passage evaluation, an expected event (strike or shear) of $12 \%$ was used to determine a bead sample size of 317 beads to obtain $\varepsilon$ of $\leq+0.03 \%, 95 \%$ of the time. The stay vane evaluation requires beads to be released into each of the three intake bays. ERDC targeted releasing 450 beads into each of the intake bays for a total sample size of 1350 beads. 


\section{Model Experiment Results}

\section{Stay vane cascade results}

Approximately 450 beads were released into each intake bay at various elevations and lateral locations. They were filmed as they passed through the stay vane and wicket gate region. The high-speed video was then reviewed, and the individual beads analyzed as discussed above. Percentages of beads experiencing a severe contact or severe change direction and the standard error (SE) associated with the data was calculated. Results for beads released into all bays were combined into one data set for each of the three operating test points. These operating points corresponded to the L1\%, Peak, and GenL (all at $55 \mathrm{ft}$ head). Results for these experiments are provided in tabular format in Plate 11. These three operating points cover the entire operation range of the turbine at $55 \mathrm{ft}$ head during fish passage season.

Average bead contact score for the three operating points (Plate 12) was highest at GenL (5.78) and was lowest at L1\% (5.61) with a score of 5.68 at Peak. Higher scores indicate a better passage condition, with 6.0 being a perfect score. The percentage of beads experiencing a severe contact (1s and 2S) with a surface was 2.3\% (SE 0.52) at GenL compared to 2.8\% (SE 0.44) at Peak and 3.8 at L1\% (SE 0.52) (Plate 13). This indicates fewer severe contacts with the stay vane and wicket gate cascade occur with increasing wicket gate openings.

There was a higher trend in the change-in-direction scores for the three operating points for more open wicket gates (3.69 at L1\%, 3.76 at Peak, 3.83 at GenL). The percentage of beads observed to exhibit a severe change-in-direction score of 1 was nearly the same at Peak (1.3\%, SE 0.31) and GenL (1.2\%, SE 0.30), with a higher percentage at L1\% (1.8\%, SE o.36). The percentage of beads observed to have a sudden change-indirection scores of 1 and 2 was lowest at GenL operating point (6.2\%, SE o.65) compared to stay vane passage at Peak (9.0 \%, SE 0.76). The percentage of beads observed to have a change-in-direction of scores of 1 and 2 was significantly highest at L1\% (13.1\%, SE 0.91). Graphical representations of change-in-direction scores and beads exhibiting a severe change in direction, during stay vane cascade passage, are shown in Plates 14 and 15 . 
A slightly increasing (although not significant) product score trend occurs with increasing wicket gate opening for stay vane wicket gate passage. The product score is obtained by multiplying the contact score by the changein-direction score and is an indication of the overall impact of passage through the stay vane and wicket gate cascade (the higher the score the better the passage route). The product scores (Plate 16) varied very little across the evaluated operational range (21.01 to 21.14).

The rate of bead passage through the stay vane and wicket gate gap was also determined for each of the three test conditions identified above. Results are reported as a percentage of the overall number of beads in the data set. The highest gap passage rate occurred at the operating point corresponding to the L1\% (6.6\%) compared to $2.9 \%$ at Peak and was lowest GenL (1.9\%). All of the 6.6\% gap passage occurring at L1\% does not result in poor passage conditions but a significant number pass without significant contact or severe changes in directions. A graphical representation of stay vane-to-wicket gate passage is shown in Plate 17. For minimizing gap passage, it would be better to operate at operating points with larger wicket gate openings.

All results obtained for the stay vane passage investigations indicate that better conditions for fish passage occur at higher or more open wicket gates. The best condition investigated occurred at GenL, and the worst condition occurred at L1\%.

\section{Runner results}

Beads were released between the stay vanes, and their paths through the runner were imaged with high-speed cameras. Analysis and evaluation of the impacts of bead strike and change in direction were completed per the procedure described previously in this report for each of the three runner regions.

\section{Runner hub region}

A total of 650 beads were released at the stay vanes such that they passed near the hub area of the runner for each of the three operating points at $55 \mathrm{ft}$ of head. The distribution of beads exiting the runner for all hub releases is provided in Plates 18-20. Bead evaluation results for the hub region in tabular format are shown in Plate 21. 
The bead passage contact scores for passage through the runner hub region were lowest (5.38) for the operating point corresponding to the L1\% and nearly the same for Peak and GenL (5.62 and 5.65). The higher the number the better the operating point is for reducing surface contact. Based on ERDC experience, the difference between L1\% and the other two operating points is significant. The contact score includes all surface contacts through the runner including minor contacts as well as severe contacts. This shows a trend for fewer overall contacts at higher blade angles. To reduce overall contacts in the hub region, it would be better to operate the turbine at higher BAs. A plot of contact scores across the operating range is provided in Plate22.

The percentage of beads exhibiting a severe contact (1s and 2s) with a surface in the hub area was lowest at GenL (3.2\%, SE 0.69) and then Peak (3.7\%, SE 0.74\%) and significantly higher at L1\% efficiency (6.0\%, SE 0.93). To minimize severe contacts in the near hub region, it is best to operate with steeper blade angles and avoid the flattest BA (Plate 23).

The change-in-direction score was lower for operating points corresponding to the L1\% compared to the other evaluated operating points (Plate 24). The L1\% score was 3.24 compared to 3.40 at Peak and 3.37 at GenL. Higher change-in-direction scores are better than lower scores indicating smoother hydraulics with less potential for shear.

The percentage of beads observed to make a severe change in direction (1s) passing through the hub region was higher at operating point corresponding to the L1\% (4.8\%, SE 0.84) compared to the two other evaluated operating points at steeper BAs. The percentage of beads exhibiting a severe change-in-direction score was best at the operating point corresponding to the GenL\% operating point (2.0\%, SE 0.55\%) followed by Peak (2.5\%, SE 0.61). Plate 25 shows the differences across the evaluated operating points. Operating at steeper BAs would be best to minimize undesirable hydraulic shear zones for juvenile salmon passing through the hub region. Operating at L1\% should be avoided to minimize exposure to poor hydraulic conditions fish would encounter in the hub region. Although the distribution of fish entering the turbine is uncertain, a significant number of fish may pass through this region, even with screens in place. A larger percentage of fish would be expected to pass through the hub zone if screens are removed. 
The hub bead passage product score for the upper two evaluated operating points was significantly higher (19.52 and 19.68) compared to L1\% operating point (18.33). Higher scores are better and indicate better operating points to operate for fish. Plate 26 graphically shows the difference across the evaluated operational points. These product scores indicate that a much better operational zone for fish passing near the hub would be at and above the peak operating point (steeper BAs), and operating at flatter BAs should be avoided.

The number of beads passing through the runner hub to blade gap was recorded for each operating point. Significantly more beads passed through the gap at the operating point corresponding to L1\% (5.1\%) compared to Peak (2.0\%). The gap passage was (0.5\%) lowest at GenL. Fish passage through this gap would be subjected to high rates of shear and severe contacts. This indicates that operating at the flat BA of $16.5^{\circ}$ should be avoided. Operating at steeper blade angles reduces fish exposure to this gap area. A plot of percentage of beads passing through the gap vs. BA is provided in Plate 27. The TOR for improved hub passage would be from Peak to GenL. Additional tests points between Peak and L1\% would have to be conducted to further refine this operational zone.

With screens installed, passage through the hub should be reduced compared to a screened intake, as the fish that pass through the top of intake are screened out.

However, the screens impart a significant amount of turbulence to flow in the intake downstream of the screens resulting in the potential for fish to pass through the hub area.

\section{Runner mid-blade region}

Beads were released at the entrance to the stay vane cascade resulting in runner mid-blade region passage. The release was positioned at a mid-stay vane height between the stay vanes and positioned to ensure that there was no bead contact with any stay vanes or wicket gates. The distribution on beads exiting the runner for each operating point is shown in Plates 28-30. Fewer beads were released for the mid-blade evaluation than for the hub or tip regions of the runner. This is because the mid-blade region is expected to be a better passage route than the blade tip or hub region (based on ERDC experience on other runner evaluations) resulting in lower blade surface contact and lower incidences of severe changes in 
direction. This allows for releasing fewer beads to obtain the same precision as other passage routes with higher expected runner interactions. An amount of 450 beads was the targeted sample size. This sample size was used for all three operating points. Plate 31 shows the results for the mid-blade region including sample size and precision obtained at each operating point.

The bead passage contact scores for passage through the mid-hub region were lowest (5.79) for operating point corresponding to the L1\% nearly the same for Peak and GenL (5.87 and 5.88). The higher the number is, the better the operating point is for reducing surface contact. The contact score includes all surface contacts through the runner including minor contacts as well as severe contacts. These scores indicate a trend for fewer overall contacts at higher BAs. To reduce overall contacts of juvenile salmon in the mid-blade region, it would be better to operate the turbine at higher BAs. A plot of contact scores across the operating range is provided in Plate 32.

Percentage of severe bead contacts (1s and 2s) with the runner in the midblade region was highest at the operating points corresponding to the $\mathrm{L} 1 \%$ (3.1\%, SE 0.82) compared to peak efficiency and Gen (both $=1.1 \%$, SE 0.49). The difference in severe contacts between $\mathrm{L} 1 \%$ and the two steeper BAs is significant. These data indicate that it is better to operate at steeper BAs to reduce the potential for fish encountering a severe contact with the runner blade at the mid-blade region. Operation at flatter BAs increases the potential for severe contact with the runner blade in the mid-blade region. Although the distribution of fish passing through the runner is unknown, a significant percentage of fish passing through the runner would be expected to pass through the mid-blade region. This would be expected with or without screens in place. A plot of the percentage of severe contacts vs. blade angle is shown in Plate 33.

Change-in-direction scores for the mid-blade region (Plate 34) were highest at the operating point corresponding to the GenL (3.70) followed by Peak (3.65). The change-in-direction score was lowest at L1\% (3.39). These data indicate that operating at steeper blade angles decreases turbulence in the mid-blade region compared to flatter blade angles.

The percentage of beads experiencing a severe change in direction (1s) was significantly higher for L1\% operating point (3.1\%, SE 0.82\%) compared to both Peak (0.7\%, SE 3.8) and GenL (0.8\%, SE 0.41\%). These data indicate 
that it is better to operate at steeper BAs to reduce the percentage of beads (fish) experiencing a severe change in direction in the mid-blade region. Operating at flatter blades angles increases the potential for fish to experience a severe change in direction (higher shear) in the mid-blade region. A graphical representation of percentage of beads with severe changes in direction for beads passing through the mid-blade region is provided in Plate 35.

Product scores for the mid-blade region did not differ significantly between Peak and GenL (21.65 compared to 21.95). It was lower for L1\% (20.95). A graphical representation of the product scores for beads passing through the mid-blade regionis provided in Plate 36.

\section{Runner blade tip region}

A total of 650 beads were released at the stay vanes (bottom of stay vanes) such that they passed through the runner blade tip region of the MGR for each of the five operating points at $55 \mathrm{ft}$ of head. The release points were positioned between pairs of stay vanes to ensure that there was no contact with stay vanes or wicket gates and as close to the invert of the stay ring as possible. The distribution on beads exiting the runner for each operating point in the tip region is shown in Plates 37-39. Also, the bead evaluation results for the tip region are shown in Plate 40.

For beads passing through the blade tip region, contact scores were highest for BAs of $20.3^{\circ}$ (5.67 at Peak) and the steepest blade angle of $26.5^{\circ}(5.65 \mathrm{GenL})$. The lowest contact scores for the tip region occurred at the flattest blade angle of $16.5^{\circ}$ (5.53 at L1\%). These data indicate that when considering all contacts in the blade tip region, it is better to avoid operating the units at the flat BA of $16.5^{\circ}$ and would be better to operate at steeper BAs. A graphical representation of the contact scores for the blade tip passage region is provided in Plate 41.

The percentage of beads observed encountering a severe contact with the blade in the tip region was highest at the flatter BAs of $16.5^{\circ}(4.3 \%$, SE o.8\%). Passage through this region was better at the two steeper BAs with the percentage of severe contacts varying between 2.6\% (Peak - SE 0.63\%) and $2.8 \%$ (GenL - SE 0.64\%). A graphical presentation of the percentage of beads having a severe surface contact through the blade tip region is provided in Plate 42. The bead passage evaluation indicates that steeper BAs provide fewer opportunities for fish to make severe contacts with the 
runner blade in the blade tip region. It also indicates that flatter BAs should be avoided to reduce risk of fish injury due to direct contact with the runner blades in this region.

Change-in-direction scores for the tip region (Plate 43) were low but virtually the same for all evaluated blade angles varying between 3.06 and 3.07. Change-in-directions scores include all changes-in-direction scoring, severe, moderate to severe and small changes in directions.

Percentage of beads observed to make a sudden change in direction (1s) decreased when the blade angle was increased (Plate 44). This was true throughout the operational zone investigated. At the flattest BA $\left(16.5^{\circ}\right)$, the percentage of beads encountering a sudden change in direction was 9.2\% (SE 1.1), 7.1 \% (SE 1.0) at Peak and 6.5\% (SE 1.0) at the steepest blade angle $\left(26.5^{\circ}\right)$. This evaluation indicates that to improve fish passage conditions at the tip region, the turbine should be operated at steeper BAs, and the flat BA of $16.5^{\circ}$ should be avoided.

Product scores calculated for the tip passage region (Plate 45) were lowest for the $16.5^{\circ}(17.62)$ blade angle compared to 17.88 at $20.3^{\circ}$ blade angle and 17.75 for the steepest blade angle of $26.5^{\circ}$ (GenL). The product scores reflect all contacts and all changes in direction including all minor contacts and minor changes in direction. Based on ERDC experience with other Kaplan runners, product scores of 17 to 18 are not abnormally low for the tip passage region.

The lateral and depth distribution of fish approaching the B2 powerhouse is uncertain. Seasonal and diel changes affect fish distribution as well project operations. In addition, fish redistribution within the intake structure probably occurs as fish react to hydraulic conditions in the intake before entering the runner. Thus, the distribution of fish passing through the runner region is unknown. However, fewer fish would be expected to pass through the blade tip region compared to the hub and mid-blade region. Also, deep eddies along the front face of the powerhouse cause fish to sound or approach the intake at deeper depths. This adds to the uncertainty of fish distribution passing through the intake. 


\section{Runner all regions combined}

Bead data for hub, mid-blade, and blade tip passage routes were combined into one data set per operating point. Performing a data analysis on all the beads from all three passage routes together provides a good indication of passage conditions through the runner, assuming all passage zones are weighted equally. This allows for comparison of the operating points throughout the potential operation of the B2 runner and will indicate where the turbine should be operated as well as operating points to avoid, minimizing the impacts of the turbine on migrating juvenile salmon. Results for all releases combined are shown in tabular format in Plate 46.

The bead contact score was lowest for $16.5^{\circ}$ blade BA (5.57) compared to $20.3^{\circ} \mathrm{BA}(5.72)$ and 26.5 BA (5.73). This indicates that when considering all severities of bead contacts with the runner, it is better to operate at steeper BAs. A plot of contact score vs. blade angle for all releases combined is shown in Plate 47.

The percentage of severe bead contacts was significantly higher at $16.5^{\circ} \mathrm{BA}$ (4.5\%, SE 0.49) compared to $20.3^{\circ} \mathrm{BA}(2.5 \%, \mathrm{SE} 0.37)$ and $26.5^{\circ} \mathrm{BA}$ (2.4\%, SE 0.36) (Plate 48).

This indicates that the runner should be operated at steeper BAs to decrease the potential for fish to make a severe contact with the runner blade. An angle of $16.5^{\circ}$ BA should be avoided during fish season if possible.

The bead change-in-direction score was lowest at $16.5^{\circ} \mathrm{BA}$ (3.29). The score was the same for $20.3^{\circ}$ and $26.5^{\circ}$ BAs (3.38). This indicates a better overall passage condition for steeper BAs (reduced changing in direction) compared to flattest BA. A graphical representation of change-in-direction scores vs. blade for all regions combined is provided in Plate 49.

Percentage of beads experiencing a severe change in direction was highest for the flattest BA (Plate 50). At a $16.5^{\circ} \mathrm{BA}, 5.7 \%$ (SE 0.55) beads were observed to experience a higher rate of severe change-in-direction events in the runner region compared to $3.4 \%$ (SE 0.43 ) at $20.3^{\circ} \mathrm{BA}$ and $3.1 \%$ (SE $0.41)$ at $26.5^{\circ} \mathrm{BA}$. This comparison indicates that the runner should be operated at steeper BAs to reduce impacts of shear on fish passing through the runner region. Flatter BA of $16.5^{\circ}$ should be avoided. 
Product score was lowest at $16.5^{\circ}$ (18.97) blade angle product score compared to $20.3^{\circ}$ and $26.5^{\circ}$ BAs (both 19.74). This indicates a better overall passage conditions at steeper BAs. A plot of the product score for all releases combined is shown in Plate 51.

\section{Runner passage distribution}

The front face of $\mathrm{B} 2$ is angled at $8.1^{\circ}$ (off the vertical). In addition, a berm exists approximately $260 \mathrm{ft}$ upstream of the powerhouse at elevation 30. This causes deep lateral eddies along the upstream face of the powerhouse. Fish approaching the powerhouse become entrained into these lateral eddies and in most cases do not immediately enter the powerhouse units. The fish eventually enter the intakes at deeper depths. B2 powerhouse units also have $20 \mathrm{ft}$ long STSs installed in the intake bulkhead slots. A significant percentage of fish pass unguided into the powerhouse turbines. The screens intercept between $20 \%$ and $60 \%$ of fish entering the powerhouse units. The interception rate (fish guidance efficiency) varies between night and day, spring and summer, powerhouse loadings, between different units, and from year to year. The screens also impart a great deal of turbulence into the flow that redistributes fish downstream of the screens. Because of effects of the STSs and the upstream flow patterns, the distribution of fish entering the stay vane cascade (and runner) is unknown.

Runner bead distribution experiments were conducted to address or investigate potential distributions of fish entering the stay vane cascade and therefore the runner.

An amount of 100 beads were released at three lateral positions in each of the three bays at three elevations for three operating points. These beads where imaged as they exited the runner, using high-speed digital cameras with a frame rate of 1000 frames/s. The release elevations corresponded to tip of the STS, 5 vertical $\mathrm{ft}$ below the tip of the STS and $10 \mathrm{ft}$ lower than this elevation (Plate 52).

\section{Screen tip release}

Beads were released at the tip of the STS. From this release location, beads exiting the runner had a large radial as well as circular distribution for all three operating points (Plates 53-55). This highly scattered pattern was somewhat unexpected as the beads were released from nine distinct points but from one consistent elevation. A tabular formatted summary of the 
runner bead distribution data for this release elevation is provided in Plate 56 . For $26.5^{\circ}$ BA, $28.7 \%$ of the beads passed within 24 in. of the hub, but only $7.1 \%$ of the beads passed within 24 in. of the runner blade tip. Similar results were observed for the two other blade angles. An amount of $30.7 \%$ of the beads passed within 24 in. of the hub at $20.3^{\circ}$ BA compared to $31.1 \%$ at the flat BA of $16.5^{\circ}$. An amount of $6.6 \%$ of the beads passed within 24 in. of the tip of the blade for both $20.3^{\circ}$ and $16.5^{\circ}$ BAs.

The percentage of beads passing within 24 in. of the runner hub was higher than expected considering that the STSs screen approximately $22.4 \%$ of the total intake flow (all top of intake flow).

In addition to bead distribution, the number of beads passing through runner gaps was also determined. An amount of $1.6 \%$ of the beads passed through the runner hub gap for both the $16.5^{\circ}$ and $20.3^{\circ}$ BAs. The runner hub gap passage was reduced to $0.3 \%$ at the steepest BA $\left(26.5^{\circ}\right)$. No beads were observed to pass through the blade tipgaps.

Note that the distribution of beads passing through runner for each intake bay at this release elevation was different at each operating point. Bay A had a significantly lower percentage of beads passing through the hub region and more passing through the mid-blade region compared to Bays $\mathrm{B}$ and C. Plots of runner passage bead distributions from each bay at all three operating points are provided in Plates $57-59$.

\section{$5 \mathrm{ft}$ below screen tip release}

The release location was lowered $5 \mathrm{ft}$, and the beads exiting the runner (as documented for the screen tip release) had a large radial as well as circular distribution at all three operating points (Plates 60-62). A tabular formatted summary of the runner bead distribution data for this release elevation is provided in Plate 63. Slightly fewer beads passed within 24 in. of the runner hub when compared to the screen tip release (for all three operating points). The hub to blade gap passage varied from $0.3 \%$ at $26.5^{\circ}$ BA to $2.3 \%$ at $20.3^{\circ} \mathrm{BA}$. The passage rate was $1.8 \%$ at $16.5^{\circ}$. These gap passage results are very similar to what occurred for the screen tip releases. The percentage of beads passing the tip region for the $5 \mathrm{ft}$ lowered releases was low and was also nearly the same rate occurring for the screen tip release (at all three operating points). The highest percentages of beads passed through the mid-blade region. An amount of 
$63 \%$ of the beads passed the mid-blade region at $20.3^{\circ} \mathrm{BA}$ compared to $65.7 \%$ at $16.5^{\circ} \mathrm{BA}$ and $66.2 \%$ at $26.5^{\circ} \mathrm{BA}$.

The runner passage distribution varied between the three intake bays at this release elevation (Plates 64-66). A significantly lower percentage of beads passed within 24 in. of the runner hub for the Bay A releases compared to Bays $\mathrm{B}$ and $\mathrm{C}$ releases. Bay $\mathrm{C}$ releases had the greatest percentage of beads passing near thehub.

\section{$15 \mathrm{ft}$ below screen tip release}

A wide distribution of beads exiting the runner was documented (both radial and lateral) for the $15 \mathrm{ft}$ below screen tip release points. This can be seen in Plates 67-69. The percentage of beads passing within 24 in. of the hub was significantly reduced compared to the other two release elevations. The percentage of beads passing within $24 \mathrm{in}$. of the at hub at this release elevation was $8.8 \%$ at $26.5^{\circ}, 10.5 \%$ at $16.5^{\circ} \mathrm{BA}$, and was lowest at $20.3^{\circ} \mathrm{BA}(6.8 \%)$. But even with these low hub passage rates, between $0.8 \%$ and $1.0 \%$ of the total beads was observed to pass through the hub-torunner blade gap. The amount of tip passage significantly increased for this release elevation when compared to the other two higher release elevations. The largest percentage of beads passed through the midblade area. At this release elevation, between $54.7 \%\left(16.5^{\circ} \mathrm{BA}\right)$ and $59.6 \%$ $\left(20.3^{\circ} \mathrm{BA}\right)$ of the beads passed through the mid-blade region. A tabular formatted summary of the bead distribution data for this release elevation can be seen in Plate 70.

As documented for the two previous release elevations, there was a significant difference in runner passage distributions between the intake bays. More beads passed within 24 in. on the hub and fewer beads passed within 24 in. of the runner tip for Bay A releases compared to releases from Bays B and C (Plates 71-73).

\section{Combining screen tip and $\mathbf{5} \mathbf{f t}$ lowered releases}

Runner distribution results for the tip of STS and $5 \mathrm{ft}$ lowered release elevations were combined into one data set at each operating point (Plate 74). Discounting fish behavior, this would predict a runner passage distribution for the majority of unguided fish passing within $5 \mathrm{ft}$ of the screen tip. A high number of beads passed though the hub region. An amount of $30.8 \%$ of the beads passed within 24 in. of the runner hub at 
$20.3^{\circ}$ BA compared to $29.2 \%$ at $16.5^{\circ} \mathrm{BA}$ and $27.4 \%$ at $26.5 \mathrm{BA}^{\circ}$. The hub passage rates were higher than expected considering the STS intercepts the top 22.4\% of the intake flow. Runner-to-hub gap passage rates were lowest at $26.5^{\circ} \mathrm{BA}(0.3 \%)$ compared to $20.3^{\circ} \mathrm{BA}(1.9 \%)$ and $16.5^{\circ} \mathrm{BA}$ (1.7\%).

Low passage rates through the tip passage region occurred for these releases. The passage rates were lowest at $20.3^{\circ} \mathrm{BA}(6.3 \%)$ followed by $16.5^{\circ} \mathrm{BA}(6.8 \%)$ and then by $26.5 \mathrm{BA}(7.4 \%)$.

The highest percentage of beads passed though the mid-blade region for these releases and were similar for all three operating points. The midblade passage rate was highest at $26.5^{\circ} \mathrm{BA}(65.2 \%)$ and lowest at $20.3^{\circ} \mathrm{BA}$ $(62.5 \%)$. These rates are more than double the rates occurring through the hub passage region and therefore would be weighted higher for better fish passage zone.

For this intake passage distribution (within $5 \mathrm{ft}$ of screen tip), the most prominent passage route is the mid-blade region followed by a significant percentage through the hub region. While the tip passage region cannot be totally discounted, it would not contribute much to the mortality rates for turbine passage.

\section{Combining all release elevations}

All runner passage distribution data for all three release elevations were combined for each operating point (Plate 74). The percentage of beads passing the hub region was fairly uniform for the three operating points but lower than the previous evaluation with the top two release elevations combined. The hub region passage percentages ranged from $21.2 \%$ to $22.9 \%$. The percentage of beads passing through this region is significant.

The percentage of beads passing the tip region increased for each operating point compared to the previous evaluation and ranged from $15.4 \%\left(20.3^{\circ} \mathrm{BA}\right)$ to $16.4 \%\left(26.5^{\circ} \mathrm{BA}\right)$. Tip passage is still a lower percentage than the hub region and much lower than mid-blade region but is not insignificant.

The mid-blade region passage rates were much higher compared to hub and tip passage and varied little (62.4\% to 60.9\%) throughout the evaluated operation range. These passage percentages are a little lower 
compared to the previous evaluation with the top two release elevations combined.

Combining all three release elevations into one data set to represent fish distribution passing through the intake is not unreasonable to get a feel for percentages of fish passing different areas of the turbine. From this evaluation, the highest percentage of fish would pass though the mid-blade region, but both hub passage and tip passage will significantly contribute to overall mortality rates for turbine passage. This is because the passage conditions through the hub and tip regions are significantly worse than the mid-blade region. If fish are entering the intake significantly distributed deeper than the $15 \mathrm{ft}$ lowered model release, then the percentage passing the tip area will increase and the percentage passing the hub region will decrease. The distribution would have to be very different to significantly affect the percentage passing the mid-blade region. For assessing different regions for the B2 turbines for fish passage, the mid-blade region should be weighted higher than the hub or tip regions.

If screens are removed, the distributions of beads passing through the turbine would be significantly different. Many more beads (fish) would pass through the hub region when compared to a screened condition. Also, how fish redistribute downstream of the screens due to their behavior may significantly affect turbine passage distributions.

\section{Draft tube exit region}

The horizontal velocity components (upstream to downstream) of flow through each draft tube barrel were measured with an LDV system for three operating points at $55 \mathrm{ft}$. Plots of the velocities obtained at the test cross section for all three operating points are provided in Plates 75-77. The velocity from these cross sections was used to determine the flow split between the two draft tube barrels, determine the uniformity of flow, and determine the draft tube barrel turbulence intensity. Results from the evaluation are provided in tabular form in Plate 78.

The flow split determined from the measured velocities was non-balanced for all the operational points tested but was the most non-balanced at the flattest blade angle. At a $16.5^{\circ} \mathrm{BA}$, Barrel C (right barrel looking downstream) carried approximately $18.9 \%$ of the flow compared to $81.1 \%$ for Barrel A. The percentage of flow in Barrel C increased to $38.4 \%$ at $20.3^{\circ} \mathrm{BA}$ and to $34.5 \%$ at a $26.5^{\circ}$ BA. Based on other studies conducted by 
ERDC on other Kaplan turbines, Barrel A normally carries more flow than Barrel $\mathrm{C}$ throughout the operation zone. Normally, the lower the turbine loading is, the more unbalanced the flow will be between the draft tube barrel. But the disparity in flow between the barrels for B2 at $16.5^{\circ} \mathrm{BA}$ is unusual when compared to other Kaplan turbines that ERDC has investigated. This an indication that the draft tube does not perform well with the $\mathrm{B} 2$ runner design. The $16.5^{\circ} \mathrm{BA}$ should be avoided, and the turbine should be operated at steeper BAs to improve flow in the draft tube. A graphical presentation of the data is provided in Plate79.

Barrel A turbulence intensity was highest at L1\% (27.6\%) and was lowest for GenL (17.2\%). These intensity levels values are low, indicating low turbulence levels exiting Barrel A. For Barrel C, the turbulence intensity was significantly higher compared to Barrel A. The turbulence intensity improved with increasing turbine discharge. The turbulence intensity at L1\% for Barrel C was $72.4 \%$ and $48.7 \%$ at GenL. This indicates the unit should be operated at higher turbine loadings to minimize the effects of turbulence near the draft tube exit on fish disorientation and stress. A graphical presentation of the results is provided in Plate 80.

Barrel A draft uniformity varied from $47.5 \%$ at $\mathrm{L} 1 \%, 21.1 \%$ at Peak, to $19.2 \%$ at GenL. While a value of $47.5 \%$ is an indicator of fairly nonuniform exit flow, $19.2 \%$ is an indicator of good exit flow uniformity. Barrel $\mathrm{C}$ flow was less uniform than Barrel A for all three operating points evaluated. The L1\% Barrel C had the worst uniformity of flow (63.9\%) compared to GenL (53.5\%) and Peak (46.0\%). Even though the uniformity of flow was poor near the draft tube exit, very little reverse flow was documented at the downstream measurement section. A graphical presentation of the results is provided in Plate 81. This evaluation shows that to provide the most uniform flow exiting the draft tube, it is best to operate between peak and generator limit. It also indicates that at the L1\% operating point, uniformity of flow is very poor, and operating at this BA should be avoided during fish passage season.

\section{Egress evaluation}

The draft tube exiting flow is turbulent, unsteady, and changes throughout the operational points of the turbine. All of this is reproduced and can be evaluated with a physical turbine model. This model is the best tool available for evaluating local effects of turbine operations on downstream egress. In the model, the flow downstream of the draft tube is in a confined 
flume. This is not representative of conditions at the prototype. However, since $\mathrm{B} 2$ has a tailrace that is isolated from the spillway, it is a reasonable approximation for a unit that has the adjacent units running. Additionally, the model bathymetry is representative of the prototype, therefore minor changes in individual unit bathmetry would have minor affects on egress conditions. This model egress evaluation does give a relative comparison of the affect that varying turbine operating points will locally have on fish exiting the draft tube (e.g., potential for backroll entrainment, average depth of tailrace passage, average time it takes to pass the turbine boil). Project operations will affect predator horizontal and vertical distributions as well as overall tailrace conditions. An amount of 810 beads were released into the intake for two operating points at $55 \mathrm{ft}$ head (Plate 9). These operating points were Peak and GenL. The beads were imaged as they exited the draft tube to a point 200 prototype $\mathrm{ft}$ downstream of the draft tube exit. Results from the egress evaluation are provided in tabular format in Plate 82.

The percentage of beads entrained into the backroll was very low at GenL (3.7\%). The rate of entrainment at L1\% was higher (19.4\%). Lower backroll entrainment rates are considered to be better. The backroll area has the potential to have higher rates of avian and fish predation. A graphical representation of the backroll entrainment rates is provided in Plate 83 .

As beads passed through the tailrace area, the number of beads that were observed to come into contact with the water surface or within $5 \mathrm{ft}$ of the water surface was documented. The percentage of beads coming into contact with the water surface was lowest for GenL (17.8\%) and increased to $24.6 \%$ at $\mathrm{L} 1 \%$. The trend was the same for the beads passing within $5 \mathrm{ft}$ of the water surface. It was lowest at GenL\% (19.5\%) and highest at L1\% (34.0\%). The lower in the water column, the more likely the fish would pass downstream with reduced exposure to avian predation. A graphical representation of the results is provided in Plates $84-85$.

The time it took the bead to exit the draft tube and pass $200 \mathrm{ft}$ downstream was recorded for each bead. The average time was the shortest for GenL\% (59.7 s) and much longer for L1\% (119.3 s). Shorter time would indicate a shorter exposure time to predation in the turbine boil area. A graphical representation of the results is provided in Plate 86 . 
Overall the egress evaluation provided consistent results. Lower turbine loadings caused a larger percentage of beads to become entrained into the backroll and had more beads coming into contact with water surface (to a distance of $200 \mathrm{ft}$ downstream). Higher turbine loadings had fewer percentages of beads exposed to the top $5 \mathrm{ft}$ of the water surface, and the average bead took much less time to move beyond the turbine boil. Taking all the evaluated metrics into consideration, the steeper BA should provide better egress conditions. Noted, this evaluation is comparative for only a single unit operation and does not take into account effects of multiple unit operations. 


\section{Model Target Operating Range (TOR) Conclusions and Recommendations}

Experiments were conducted to compare entire turbine passage routes that affect direct and indirect fish survival throughout the operating range of the B2. The results will assist in determining the TOR to minimize impacts on juvenile salmon passing through the B2 powerhouse.

Operation within the TOR should reduce fish mortality, injury, stress, and fish disorientation, thereby increasing fish survival for fish passing through the B2 turbines. The modeling results are not direct predictors of survival but are a relative comparison of operating points throughout the complete operation zone at $55 \mathrm{ft}$ of head.

\section{Stay vane passage}

Experiments for stay vane and wicket passage indicate that when considering surface contact and shear, operating point GenL provided the best passage followed by Peak. Operating at L1\% provided the least favorable passage and is dramatically worse than the other two operating points. B2 stay vanes have beveled leading and trailing edges and are fairly well aligned with flow entering the stay vane cascade. This allows for little flow separation at the leading edge, but this beveled leading edge also provides a more pointed edge that may not be the best design for fish. Stay vane-to-wicket gate gap passage decreased with increasing wicket gate angle. This gap passage is considered to be negative and is a potential injury point for juvenile salmon. Stay vane passage optimization is important for minimizing fish injury, disorientation, and stress.

\section{Runner hub region passage}

Observed severe blade contact was significantly higher at the flatter BA of $16.5^{\circ}$ compared to what was observed at $20.3^{\circ}$ and $26.5^{\circ}$ BAs. Also, the same trend was observed for the percentage of beads exhibiting a severe change in direction while passing through this region. The flatter blade angle of $16.5^{\circ}$ had a significantly higher percentage of beads with sudden changes in direction compared to the other two steeper blade angles. In addition, hub-to-blade gap passage was very high at $16.5^{\circ}$ compared to the two steeper blade angles with the least occurring at $26.5^{\circ}$. With screens in place, it is unknown what percentage of the total fish population would be expected to pass through the hub region. This region cannot be discounted 
because of the redistribution of beads (or fish) occurring due to turbulence caused by the screens and without knowing how fish behavior would affect fish distribution downstream of the screen. Distribution bead tests indicate that a significant number of beads (fish) could still pass through this region.

\section{Runner mid-blade region passage}

Overall mid-blade passage was observed to be the best passage route through the turbine when compared to hub and near blade tip passage. The number of beads observed to have a severe contact event with the blade was low for both $20.3^{\circ}$ and $26.5^{\circ}$ BAs but was significantly higher at the $16.5^{\circ} \mathrm{BA}$.

Beads observed to exhibit severe changes in direction had a similar rate of occurrence as severe contacts. This indicates that the majority of severe change-in-direction events occurred as the result of severe contact. When the moderate change-in-direction events are added to the severe events, the rate of event occurrence is highest at flattest BA.

A significant percentage of the total fish population would be expected to pass through the mid-blade region. This is especially true with screens in place. Based on this bead evaluation, the TOR for the mid-blade region would be from Peak to GenL. Flatter blade angles should be avoided during fish passage season.

\section{Runner tip region passage}

The percentage of beads making severe contact with the runner blade was highest at the flattest $\mathrm{BA}\left(16.5^{\circ}\right)$ when compared to the two steepest BAs, with the percentage at $20.3^{\circ} \mathrm{BA}$ and $26.5^{\circ} \mathrm{BA}$ being approximately the same. Also, the rate of beads observed to exhibit a severe change in direction had a trend of reduction as the blade angle was increased. Fewer fish would be expected to pass through the tip region when compared to the mid-blade passage region. However, some fish would be expected to pass though this region. In addition, the fish distribution approaching the turbine is unknown, so this region cannot be excluded. To provide for the best conditions for fish passage, the unit should be operated at steeper blade angles, and minimum blade angles should be avoided during fish passage season. 


\section{All turbine region combined passage}

Since the distribution of fish entering the intake and the runner is unknown, data from the three passage routes were combined into one data set. The data indicate a trend of decreasing severe contact with the turbine blade with increasing blade angles. The same trend can be seen in the data when looking at the rates of severe change-in-direction events during turbine passage. Steeper BAs should provide better fish passage conditions compared to flatter BAs. Flatter blade angles should be avoided if possible during fish passage season.

\section{Draft tube exit region}

The flow split between the two draft tube barrels was uneven throughout the operational range of the turbine. The largest disparity between the draft tube barrels occurred at $16.5^{\circ}$ BA where $81.1 \%$ of the flow passed through Barrel A. Even draft tube loading is thought to be desirable for improved egress conditions. Quality of flow (turbulence intensity and draft tube uniformity) within each draft tube barrel was worst at the $16.5^{\circ} \mathrm{BA}$ and improved at other BAs. This indicates that to achieve better draft exit flow, it is better to operate the turbine at steeper BAs.

\section{Egress region}

Egress results and outcomes were consistent for all egress evaluation metrics. Operating at a $26.5^{\circ} \mathrm{BA}$ resulted in improved egress conditions compared to $16.5^{\circ} \mathrm{BA}$. The number of beads entrained into the backroll area was significantly less for the $26.5^{\circ} \mathrm{BA}$ compared to the $16.5^{\circ} \mathrm{BA}$. The other metrics of passage time, distance downstream to achieve minimum depth, and beads within $5 \mathrm{ft}$ of water surface were also better for the steepest BA $\left(26.5^{\circ}\right)$ evaluated.

\section{Overall turbine passage conclusion}

While the model data are not a direct predictor of fish mortality, the model data are a good method for defining and comparing hydraulic and passage conditions between turbine operating points. It is clear from the model evaluation that steeper BAs (if operated at peak efficiency for each subject blade angle) provide for better passage conditions for fish. Fewer severe contacts with the turbine runner and less severe change in direction occur at steeper BAs. The quality of flow exiting the draft tube and egress conditions are better at steeper BAs. 
In fact, the flat BA of $16.5^{\circ}$ should be avoided during juvenile fish passage season, if possible. From this model evaluation, it is recommended to operate the turbine between $20.3^{\circ}$ to $26.5^{\circ}$ BAs to improve fish passage conditions related to turbulence, shear, and blade contact. This does not constrain the operation of the turbine to BA operating range but only recommends operation of the turbine within these BA when possible and avoidance of operating at the flattest BAs. Note that operating between $20.3^{\circ}$ to $26.5^{\circ}$ BAs falls within the current $1 \%$ operating range constraints.

From the bead distribution evaluation, the highest percentage of fish should pass though the mid-blade region, but both hub passage and tip passage will significantly contribute to overall mortality rates for turbine passage. This is because the passage conditions through the hub and tip regions are significantly worse than the mid-blade region. If fish are entering the intake distributed significantly deeper than the $15 \mathrm{ft}$ lowered modeled release, then the percentage passing the blade tip area will increase and the percentage passing the hub region will decrease. The distribution would have to be very different to significantly affect the percentage passing the mid-blade region. For assessing different regions for the $\mathrm{B} 2$ turbines for fish passage, the mid-blade region should be weighted higher than the hub or tip regions.

If screens are removed, the distributions of beads passing through the turbine would be significantly different. Many more beads (fish) would pass through the hub region when compared to a screened condition. Also, how fish redistribute downstream of the screens due to their behavior may significantly affect turbine passage distributions.

Turbine passage pressure effects and project operations are important factors for a full determination of TOR for fish passage but could not be directly addressed in this study. Pressures tend to be lower with increasing turbine discharges. To fully refine the TOR, these two factors should be explored and combined with the results of this model study. 


\section{Bonneville Second Powerhouse (B2) Comparison to other U.S. Army Corps of Engineers (USACE) Projects}

Survival rates of juvenile salmon passing through the B2 turbines appear to be higher compared to other USACE projects on the Snake and Lower Columbia Rivers. One of the goals of this B2 model study is to compare B2 model results to model results obtained for other ERDC USACE turbine models. This is to determine if some part of the B2 turbine design, configuration, or operation may provide for better fish passage conditions compared to other turbines or projects. If a superior B2 metric can be identified, then it may be possible to incorporate this metric or finding at other USACE projects or at least be incorporated during future rehabilitation of USACE turbines.

ERDC has previously conducted observational model turbine studies for five other USACE powerhouses. These powerhouses include McNary, Lower Granite (Units 4-6), John Day, Ice Harbor (Units 1-3) and Bonneville First Powerhouse (B1). The primary purposes of these studies were to assist in determining TOR and support turbine rehabilitation. However, these models have also been used for Kaplan blade studies, stay vane shaping, and support of performance models. All ERDC turbine models are constructed at a 1:25-scale and constructed in the similar manner as B2 described previously in this report.

\section{Prototype operational and geometric comparison}

The existing USACE turbines on the Lower Snake and Lower Columbia Rivers were designed primarily for their power output requirements. Fish survival was not a primary design goal or requirement of their design process. During their design process, stay vane and wicket gate arrangements, turbine blade design, draft tube design, and the effect of turbine design on fish egress conditions were not really considered. The partial exception to this is B1 rehab, where the runner was designed to include minimum gap features to the runner, but no considerations were given to other attributes or other important structures such as stay vanes, wicket gates, draft tube, and effects of turbine passage on egress. Also new B1 runner design did not consider turbine pressure effect on fish survival. 
At the time of B1 rehabilitation design, only considered pressure as it relates to caviation was addressed.

There are numerous geometric and operational parameters that can be used to compare the projects. Some are head, turbine discharge, runner configuration, draft tube configuration, tailrace configuration, and runner speed.

The turbine and intake geometry for B2 was overlaid with the five other USACE powerhouses. The centerline of the runner was chosen as the control point for the overlay. These overlays are provided in Plates 87-91. In addition, project metrics for $\mathrm{B} 2$ and the other five USACE projects, such as runner speed, runner diameter, number of runner blades, project head tested, are provided in Plate 92. Operational and geometric information for each project was used to calculate tangential blade runner speeds and axial water velocity through the runner. This information can be seen in Plate 93. Detailed project descriptions and discussions of each of these projects can be found in Turbine Survival Program Phase 1 and 2 Reports (USACE 2004, 2013. Results from biological field studies, detailing survival rates through the turbines for each of these projects, is documented in TSP Phase II Main Report (USACE 2013).

\section{Prototype sensors fish pressure tests}

The Pacific Northwest National Laboratory performed sensor fish tests at Ice Harbor in 2005, John Day in 2006, and B2 in 2007. A limited number of sensor fish were released through the McNary Turbines in 2002. In addition, sensor fish were used to compare the original B1 turbines with the newly installed turbines in 1999-2000. Sensor fish are released into the flow to document pressure profiles through the turbine at various passage routes. The mean, maximum, and minimum nadir pressures as well as a time history of the pressures experienced from just upstream of the turbine, through the turbine, and through draft tube are recorded.

Compared to other projects, the B2-recorded nadir pressures are fairly high resulting in fairly low pressure related mortality probability (USACE 2013). 


\section{$B 2$ and B1 comparisons}

$\mathrm{B} 1$ and $\mathrm{B} 2$ powerhouses are located at the Bonneville project, so they operate at the same heads. The B1 powerhouse has 10 units, and the B2 powerhouse has 8 units. B1 has recently had all its runners replaced with minimum gap runners. The tailwater for these two powerhouses varies significantly throughout the year and has the greatest tailwater variability compared to the other three USACE dams on the Lower Columbia and four USACE projects on the Lower Snake River. B2 discharge ring diameter (331.2 in.) is much larger than the discharge ring at $\mathrm{B} 1$ (28o in.) and operates at lower rotational speed (69.2 rpm vs. $75 \mathrm{rpm})$. However, the tangential speed of the runner at the tip is higher for B2 $(99.9 \mathrm{ft} / \mathrm{s})$ compared to $\mathrm{B} 1(91.5 \mathrm{ft} / \mathrm{s})$ while the tangential speed of the blade at the runner hub to blade interface is nearly the same. Higher tangential speeds will potentially result in more significant fish impacts with the blade leading and trailing edges. The tangential blade speed varies along the length of the blade for all turbines. Both B1 and B2 turbines have five blades.

The velocity through stay vane and wicket gate cascade and runner varies throughout each of the project powerhouse turbine operating ranges (Plate 94). B2 1\% discharge operating range varies from $11,280 \mathrm{ft} 3 / \mathrm{s}$ to $19,700 \mathrm{ft} 3 / \mathrm{s}$ at $55 \mathrm{ft}$ head. This is much higher compared to $\mathrm{B} 11 \%$ operating range of $7,266 \mathrm{ft} 3 / \mathrm{s}$ to $9,800 \mathrm{ft} 3 / \mathrm{s}$. This results in a significantly higher average axial turbine water velocity at the upper $1 \%$ operating point through B2 turbines (39.1 ft/s) compared to B1 $(28.3 \mathrm{ft} / \mathrm{s})$. Higher axial velocities do increase the potential for injuring fish with blade contact but do have a positive tradeoff of shortening the exposure time of fish to the blade leading and trailing edges.

B1 draft tubes are unique among the USACE projects in that they have horizontal and vertical splitter piers located in the draft tube. More structure and leading edges result in higher potentials for fish contact. However, the amount of structure within B1 draft tube results in better quality of flow within the draft tube. B2 draft tube elbow is very large compared to B1 (as well as all other projects in this report). The larger elbow allows for lower average velocities but also results in some flow separation in the draft tube elbow that does not occur at other projects. While the flow separations potentially do not injure fish, they may result in increased fish disorientation exiting the draft tube. 
The topography in the tailrace downstream of the powerhouse is deeper (at comparable tailrace elevations) for B2 and provides for a significantly larger flow depth. This may allow for better egress conditions when combined with higher turbine discharges. The tailrace channel for both B2 and $\mathrm{B} 1$ are isolated from each other and from the spillway and are not directly influenced by spillway flow.

The topography upstream of B2 differs greatly from B1 (as well as the other four subject powerhouses). A shelf left over from the dam construction exists at B2. This shelf results in a significantly shallower approach flow upstream of the powerhouse topography coupled with the blunt shape of the intake entrance causes a deep, two-directional lateral eddy along the front face of the powerhouse. This affects fish distribution and possibly fish depth acclimation entering the powerhouse differently compared to B1 (and the other four subject powerhouses).

Most of the powerhouses on the Lower Snake and Lower Columbia Rivers have diversion screens installed in the intake upstream of the turbines for diverting fish away from the turbines. B2 has $20 \mathrm{ft}$ long STSs installed while B1 had its diversion screens removed because of problems with its bypass system. The diversion screens intercept and bypass a significant percentage of fish passing into the intake structure. In addition, the screens impart a significant amount of turbulence into the flow approaching the turbine. This turbulence affects the distribution of fish downstream of the screens. In other words, the fish would be expected to be more widely distributed due to screen effects. The flow approaching the B1 turbine is unaffected by screens, and the distribution of fish approaching the turbine would be expected to be higher in the intake and therefore pass more near the hub to mid-blade region. Of course, fish distribution in the vicinity of the stay vane cascade is not known for any project, and the effects of behavior of the fish in this region are also unknown. Fish injury and mortality of fish passing through the turbine are passage distribution dependent.

Pressure effects on fish passing through the turbine is an important factor for fish mortality and injury. It would be expected that these two projects would have somewhat different pressure impacts through their operation ranges (compared to each other). This would have to be determined through prototype pressure tests, performance models, and CFD modeling along with fish distribution studies. Acclimation depth of 
fish approaching the powerhouse as well as distribution of fish passing through the turbine will influence the injury and mortality rates if turbine pressures are at undesirable levels where the fish are passing through the turbine. Actual fish acclimation depth, as it relates to turbine passage, is essentially an unknown.

\section{B2 and John Day comparison}

John Day intake structure is significantly taller than B2 (Plate 88) and is a higher head project. The discharge through the $1 \%$ operating range for the two turbines is somewhat similar with the L1\% nearly the same and the upper $1 \%$ being 1,000 ft $3 / \mathrm{s}$ greater for John Day (compared at B2 Head $55 \mathrm{ft}$ and John Day at $102 \mathrm{ft}$ ). However, since the B2 discharge ring is larger, the average axial velocity for $\mathrm{B} 2(39.1 \mathrm{ft} / \mathrm{s})$ is significantly lower compared to John Day (48.6 ft/s) at U1\%. Also, the rotational speed of John Day (90 rpm) is faster compared to B2 (69.2 rpm). This results in a much higher tangential runner blade tip velocity for the John Day runner $(122.4 \mathrm{ft} / \mathrm{s}$ vs $99.9 \mathrm{ft} / \mathrm{s})$. The same is true for the tangential speed of the blade at the runner blade to hub junction. The number of runner blades is another positive attribute of the B2 runner. The B2 runner has five blades compared to six for John Day.

Both B2 and John Day have $20 \mathrm{ft}$ submerged traveling screens installed in the intake. The screen affects fish distributions through the intake for unguided fish, but the B2 distributor is higher in the intake compared to the John Day distributor.

The diversion screen potentially affects distribution of unguided fish approaching the stay vane cascade at $\mathrm{B} 2$ to a greater extent when compared to John Day. A larger effect of turbulence on distribution of beads entering the stay vane cascade exists for B2 compared to John Day. This was observed during comparable or similar experiments performed for both models.

The invert and roof of the draft tube exit of B2 are significantly flatter compared to John Day. This allows for exiting flow to enter the tailrace in a manner that should reduce fish entrainment into the back roll. The depth of water at the draft tube exits are similar for these two projects. However, the topography downstream of B2 is significantly deeper and potentially allows for fish to have a larger distribution, which may help reduce predation rates in the tailrace. In addition, the tailrace channel for B2 is isolated from the 
spillway and therefore is not directly influenced by spillway flow. The powerhouse at John Day is not isolated from the spillway, and therefore flow exiting the powerhouse is affected by spillway flow.

\section{B2 and McNary comparison}

McNary is a higher head project with a large, smooth intake roof shape (Plate 89). Flow is straight into the McNary powerhouse compared to the deep lateral eddies at $\mathrm{B} 2$. The McNary fish diversions screens are $40 \mathrm{ft}$ long screens compared to the $20 \mathrm{ft}$ length for $\mathrm{B} 2$. The McNary screens impart a great deal of turbulence to the flow downstream of the screens and affect the distribution of unguided fish into the turbine. The effect of the $40 \mathrm{ft}$ screens causes much more turbulence in flow approaching the turbine compared to $20 \mathrm{ft}$ screens. However, the $40 \mathrm{ft}$ screens intercept more fish at McNary compared to $20 \mathrm{ft}$ screens at $\mathrm{B} 2$. The bottom line is that the different length screens affect distribution of unguided fish to different extents and thus influence the distribution of unguided fish through the turbine to different extents. Also, screens greatly affect flow distributions approaching the turbine and add more turbulent flow into the runner, which affects the way the turbine operates. Longer screens have a greater effect on turbine operations CAM.

The upper 1\% operating point discharge for McNary is significantly lower compared to B2. McNary has significantly more operational capacity beyond its upper $1 \%$ operational fish limit while B2 does not. The runner speed for McNary is greater (85.7 rpm) compared to $\mathrm{B} 2$, and the diameter of the runner for B2 is significantly larger. The tangential speed of the runner tip is lower for B2 $(99.9 \mathrm{ft} / \mathrm{s})$ compared to McNary $(104.6 \mathrm{ft} / \mathrm{s})$. Additionally, the tangential speed of the blade at the runner blade to hub junction is significantly higher for McNary compared to B2 $(50.4 \mathrm{ft} / \mathrm{s}$ vs. $39.7 \mathrm{ft} / \mathrm{s}$ ). The average axial turbine velocity at the upper $1 \%$ is a little higher for B2 (39.1 ft/s vs. $37.2 \mathrm{ft} / \mathrm{s})$, but at comparable discharges the axial velocity for the B2 runner would be significantly slower.

The exit draft tube invert exit slope is flatter for $\mathrm{B} 2$, and the depth of water at the draft tube exit is significantly deeper for B2. The depth of flow $150 \mathrm{ft}$ downstream of the draft tube exit is significantly deeper at B2. Also, the tailrace channel for B2 is isolated from the spillway flow. The McNary powerhouse tailrace flow is not isolated from the spillway, and tailrace conditions are greatly influenced by spillway flow. 


\section{B2 and Ice Harbor comparison}

Ice Harbor is the most downstream powerhouse on the Snake River and is a higher head project compared to B2 (Plate 90). The powerhouse is configured with two different diameter Kaplan units. ERDC investigations were performed for Units 1-3. The Ice Harbor runner is a six-blade runner. The Ice Harbor turbine unit intake structure is larger, but Units 13 runner diameters (280 in.) are smaller than B2. The speed of the B2 runner is much lower compared to Ice Harbor (69.2 rpm vs. $90 \mathrm{rpm}$ ). The result is a higher runner blade tip tangential velocity for Ice Harbor compared to B2 (109.8 ft/s vs. $99.9 \mathrm{ft} / \mathrm{s})$. In addition, the angular velocity of the blade at the hub to blade conjunction is significantly lower for B2 $(39.7 \mathrm{ft} / \mathrm{s}$ vs. $48.2 \mathrm{ft} / \mathrm{s})$.

The discharge range within the $1 \%$ operating zone is larger for $\mathrm{B} 2$ (compared at $96 \mathrm{ft}$ head for Ice Harbor and $55 \mathrm{ft}$ at B2). The upper and lower 1\% discharges for B2 are significantly higher than Ice Harbor. Even though the discharges are significantly higher at B2, the average water velocity through the runner is slightly lower. This is due to the much larger discharge ring at B2, which results in significantly larger flow area.

The draft tube elbow is much larger at B2 compared to Ice Harbor and the B2. The draft tube exit geometry is much flatter at B2, and the downstream topography is much deeper at B2. Also, depth of water at the draft tube exit is deeper at B2 (B2 tail water elevation $19.5 \mathrm{ft}$ ). All of these metrics may provide for better egress conditions for fish to recover and better avoid predators in the tailrace environment. In addition, the tailrace channel at B2 is confined and separated from direct effects of spillway flow. The tailrace channel at Ice Harbor is not physically separate from the spillway, and therefore the powerhouse tailrace flow can be directly affected by flow from the spillway.

The approach topography is different for the two projects and will affect fish distributions entering the intake structure differently. This effect is the same that has been discussed for previous project comparisons. Both projects have $20 \mathrm{ft}$ STSs installed in the intake. The STSs do affect the flow distribution into the stay vane cascade as well as the distribution of unguided fish. Because of the relative relationship of the stay vane cascade to the intake ceiling, this effect would be expected to be greater at B2. Fish distributions entering the stay vane cascade, and thus the runner, are 
unknown at these two projects. Survival and injury rates through turbines are dependent on the distribution of fish passing through the runner.

\section{B2 and Lower Granite comparison}

The Lower Granite powerhouse is a six-unit powerhouse with one runner design for Units 1-3 and another one for Units 4-6 (two different runner manufacturers). ERDC investigations were conducted for Units 4-6. The Lower Granite Units 4-6 have a narrower operation range compared to B2 (Plate 91) with the upper $1 \%$ discharge being greater at $\mathrm{B} 2(19,700 \mathrm{ft} 3 / \mathrm{s} \mathrm{vs}$. $18,000 \mathrm{ft} 3 / \mathrm{s}$ ). Since the discharge ring is significantly larger at $\mathrm{B} 2$, the average water velocity through the runner is lower at B2 at comparable discharges. The runner speed at Lower Granite is $90 \mathrm{rpm}$, which results in a tangential runner blade tip speed of $122.4 \mathrm{ft} / \mathrm{s}$ which is significantly greater compared to B2 (99.9ft/s).

Also, the tangential speed of the runner blade near the hub (at the blade to hub conjunction) is significantly lower for the $\mathrm{B} 2$ runner $(69.8 \mathrm{ft} / \mathrm{s} \mathrm{vs}$. $86.9 \mathrm{ft} / \mathrm{s})$.

The Lower Granite project is a higher head project, and the intake structure is much taller (Plate 91). The approach topography is much different between the two projects. As discussed during the other project comparisons, B2 has a relatively shallow depth of approach flow over an upstream berm. Both B2 and Lower Granite have fairly vertical front faces at the powerhouse entrance. Due do the approach topography and the front face configuration, deep eddies occur and run laterally along the B2 powerhouse face. This affects the acclimation depth and distribution of fish entering the intake. This compares to Lower Granite where flow enters the intake straight (no significant lateral flow). Because of the nearly vertical shape of the face of the intake structure, the Lower Granite intake draws water deep in the water column, which also affects the distribution of fish entering the intake.

The John Day draft tube exit and downstream topography are very similar to Lower Granite. The comparison between the John Day and B2 of the draft tube exit and tailrace configurations is the same as for comparing Lower Granite to B2.

Lower Granite has $40 \mathrm{ft}$ extended submerged bar screen in the intake compared to $20 \mathrm{ft}$ STSs for B2. The $40 \mathrm{ft}$ screens cause a significant 
amount of turbulence to be imparted into the flow downstream of the screens. This turbulence and skewed flow distribution would also cause a large distribution of unguided fish entering the stay vane cascade. This effect would be greater than what occurs with $20 \mathrm{ft}$ screens. Also, $40 \mathrm{ft}$ screens have a greater effect on the operational cam of the turbine and a decrease in turbine efficiency compared to $20 \mathrm{ft}$ screens. Screens at different projects and different times of the fish passage season have varying fish interception efficiencies and therefore would affect turbine passage fish distributions differently. It is unknown if screen directly affects fish survival rates through turbines, but bypass screens definitely affect the turbines operational cam as well as the performance of draft tubes. As discussed for each of the project comparisons, fish distributions entering the turbine are unknown.

\section{Overall unknowns}

As can be seen from the above comparisons, there are many geometric and operational metrics that can be compared between projects. Some are head, runner speed, runner diameter, number of runner blades, turbine discharge, turbine water velocity, draft tube exit configuration, tailrace geometry, tailrace water depth, intake screens, length of screens, etc. Some would logically seem to be better for fish, some would be trade-offs, and for some, it is just not known what would be better for fish. In addition, other metrics are unknown and are very important for comparing the projects. Some of these are condition of fish entering the turbine (could be different at different projects), turbine pressure characteristics throughout the operating ranges, fish depth acclimation as they enter the turbine, distribution of fish entering the turbine, effects of project operations on egress conditions, and tailrace predator loading throughout the fish passage season.

\section{U.S. Army Engineer Research and Development Center (ERDC) data project comparisons}

The first testing of an ERDC turbine model to evaluate turbines was for the McNary project in support of TSP and then in support of the McNary Modernization Program. The turbine model techniques and methods for evaluating turbines were developed in this model between 1997 and 2002. The type of information obtained for the McNary study was mainly to support stay vane and wicket gate passage bead evaluations, runner passage bead evaluations, and draft tube quality of flow experiments. This 
information was obtained with $40 \mathrm{ft}$ screens in place. In 2015, it was discovered that the CAM information provided to ERDC for these model evaluations was incorrect. In addition, the bead sample size for the runner evaluations is one-half the size that ERDC currently uses for evaluations. Stay vane, runner, and draft tube evaluations were obtained between 2000 and 2002 and will be used to compare to B2 ERDC model evaluations.

ERDC model evaluations for other projects were conducted between 1998 and 2010. Table 3 lists the available ERDC turbine model evaluations from McNary, Lower Granite Units 4-6, B1, John Day, and Ice Harbor Units 13 to be used to compare to evaluations conducted for B2.

Table 3. ERDC turbine models evaluations by project.

\begin{tabular}{|l|l|l|l|l|l|}
\hline Project & $\begin{array}{l}\text { Evaluation } \\
\text { Performed } \\
\text { Time frame }\end{array}$ & $\begin{array}{c}\text { Stay Vane } \\
\text { Evaluation }\end{array}$ & $\begin{array}{c}\text { Runner } \\
\text { Evaluation }\end{array}$ & $\begin{array}{c}\text { Draft Tube } \\
\text { Evaluation }\end{array}$ & $\begin{array}{c}\text { Egress } \\
\text { Evaluation }\end{array}$ \\
\hline B1 & $2009-2011$ & Yes & Yes & Yes & Yes \\
\hline B2 & $2015-2016$ & Yes & Yes & Yes & Yes \\
\hline McNary & $1998-2002$ & Yes & Yes & Yes & No \\
\hline John Day & $2006-2008$ & Yes & Yes & Yes & No \\
\hline Ice Harbor 1-3 & $2005-2009$ & Yes & Yes & Yes & Yes \\
\hline Lower Granite 4-6 & $1999-2005$ & Yes & Yes & Yes & No \\
\hline
\end{tabular}

\section{Stay vane evaluation comparisons}

Stay vane and wicket gate ERDC bead evaluations where conducted for the projects listed in Table 3 utilizing the same methods as described previously in this report for the B2 project. For the stay vane and wicket gate comparison of $\mathrm{B} 2$ to the other projects, the percentages of beads exhibiting a severe change in direction, experiencing a severe contact with the stay vanes or wicket gates, and gap passage will be used.

A plot of the percentage of beads observed to exhibit a sudden change in direction vs. turbine discharge for $\mathrm{B} 2$ and the other projects can be seen in Plate 95. Compared to all other projects and operating points, the $\mathrm{B} 2 \mathrm{GenL}$ has the lowest incidence of beads exhibiting a severe change in direction. At the B2 peak point, the incidence rate is equally low to any other projects operating points. At the $\mathrm{B} 2 \mathrm{~L} 1 \%$, the incidence rate is a little higher than B1 and John Day trend lines but lower than the other projects. Overall, B2 stay vanes cascade causes less shear and thus provides for smoother flow in this region compared to the other projects. 
B2 stay vane and wicket severe contacts rates are nearly the same compared to rates for McNary, Ice Harbor, and B1 when compared at similar discharges or the trend of the data. B2 does perform better for severe contacts compared to John Day and Lower Granite through most of their operating ranges. This can be seen by observing Plate 96 . However, there does not appear to be anything (when comparing these project stay vane evaluations) that indicates that B2 design is a significantly superior design for reducing severe contact with structure in this region.

The final comparable metric for comparisons in this region is the stay to wicket gap. This gap has previously been described in this report. A plot of the passage rate vs. turbine discharge for all projects (listed in Table 3) is provided in Plate 97. At the B2 L1\%, the gap passage rates are significantly higher compared to all other projects, but as mentioned earlier in this report that for B2, at the L1\%, all gap passage is not all bad because the gap is very large and does not result in overly poor passage conditions. The gap passage rate at the B2 peak operating point is equal to McNary but significantly greater than the other projects. Finally, at the B2 GenL operating point, the rate is nearly the same as what occurs for the Lower Granite but higher than John Day (when compared at comparable turbine discharges). Compared to the other projects, the B2 stay vane and wicket cascade do not provide for lower rates of gap passage throughout its operating range.

\section{Runner regions evaluation comparisons}

A comparison of ERDC B2 evaluated beads (passing through three different regions of the turbine) to ERDC bead evaluations of B1, John Day, McNary, Ice Harbor Units 1-3 and Lower Granite Units 4-6 follows (see Table 3). The three turbine regions are hub region, mid-blade region, and near blade tip region. In addition, all three regions are combined into one data set at each project operating point and then compared between projects. Runner evaluations for the five projects where performed in similar methods to $\mathrm{B} 2$ as discussed earlier in this report.

It is a complicated endeavor (not straight forward) to compare ERDC bead runner results from one project to another. As discussed earlier, B2 has the slowest runner rotational speed but largest runner diameter. This results in different average turbine water velocities for comparable discharges; in addition, the tangential velocity of the B2 runner is high compared to other projects. These two factors vary between most of the 
other projects as well. ERDC bead evaluations are not a one-to-one predictor of direct fish mortality but are more a relative comparison between operation points of a project or for comparing the design of an existing turbine to a newly designed turbine for that project. For this report, B2 runner evaluations are compared to the other projects at comparable turbine discharges.

The comparison between the projects in the turbine region will consist of comparing the percentage of beads exhibiting a severe direction change and the percentage of beads making a severe contact with some structure in the runner region during turbine passage. This comparison will be made throughout the turbine $1 \%$ operating range (and outside for available data).

\section{Runner hub region evaluation comparison}

Plot of turbine discharge vs. percentage of beads with a severe change in direction for B2 and the other five projects is provided in Plate 98. At L1\%, the B2 hub region has the highest rate of beads exhibiting a severe change in direction compared to the other five projects (at comparable discharge). At the $\mathrm{B} 2$ peak, its severe direction performance is in the middle compared to the other five projects while at B2 GenL, it performs somewhat better (at comparable discharges).

When comparing the B2 hub severe contact performance to the other five projects, it can be seen that $\mathrm{B} 2$ has the highest severe contact rate at $\mathrm{L} 1 \%$ and performs in the middle for its Peak and GenL operating points (Plate 99).

\section{Runner mid-blade region evaluation comparison}

When comparing the percentage of beads having a sudden change in direction while passing through the mid-blade region (Plate 100), B2 L1\% performs the same as McNary and John Day but worse than B1 and Ice Harbor (at similar turbine discharges). For the B2 Peak operating point, it performs better then McNary and Lower Granite but the same as Ice Harbor and John Day. B2 had significantly fewer beads exhibiting a sudden change in direction at its GenL compared to the other projects (at similar turbine discharges). 
A plot of percentage of beads of having made a severe contact with the runner blade (in the mid-blade region) vs. turbine discharge for all ERDC evaluated projects can be seen in Plate 101. B2 had the highest percentage of beads with a severe blade contact at L1\% compared to all the other projects. However, at the B2 Peak, it had the lowest rates but nearly the same percentage as John Day and McNary. At the B2 GenL, the rate was slightly lower than John Day and significantly lower than Lower Granite.

\section{Runner near tip region evaluation comparison}

A plot of percentage of beads making a severe direction vs. turbine discharge while passing through the runner tip region for $\mathrm{B} 2$ and the other projects for all evaluated operating points is provided in Plate 102. The B2 percentage rate was lower than McNary but significantly higher than Ice Harbor, B1, and John Day (at similar turbine discharges). The B2 severe direction change percentage was lowest at its peak operational point compared to the other projects. However, at the B2 GenL, the percentage rate was higher than Lower Granite but lower than John Day (at comparable turbine discharge).

The percentage of beads making a severe contact with some structure in the tip region was nearly the same for B2 GenL compared to John Day and Lower Granite at (at comparable discharge). A plot of percentage of beads making a severe contact with structure in the tip region at all operating points for B2 and the other projects vs. discharge is provided in Plate 103. At the B2 Peak operating point, B2 had the lowest rate of severe surface contact compared to the other projects at comparable discharges. B2 had the second highest severe contact rate at the L1\% operating points compared to the other projects at similar turbine discharges.

\section{Runner all region combined evaluation comparison}

All the beads (for the three turbine passage regions) at each operating point for each project were combined into data sets with each turbine passage region weighted equally. The percentage of beads making a severe contact with a surface in the runner region and the percentage of beads exhibiting a severe change in direction during their passage through the turbine was calculated as described previously in this report.

Plots of the percentage of beads exhibiting a severe change in direction vs. turbine discharge at each operating point for each project are provided in 
Plate 104. B2 had one of the highest percentages of beads with severe bead changes in directions at L1\% (at comparable turbine discharges), but at the peak, the percentage rate was lower compared to McNary and Lower Granite and nearly the same as Ice Harbor and John Day. At GenL, B2 had the lowest severe direction change percentage (at comparable turbine discharges).

The B2 L1\% operating point severe contact percentage rate was the highest of all projects at comparable discharge rates (Plate 105). However, the percentage of beads making severe contact through the runner region was lower at the B2 Peak and GenL operating points compared to all the other projects (at comparable turbine discharges).

If all runner passage routes are weighted equally and combined, the comparative project runner bead analysis indicates that B2 seems to perform as well or a little better for operating points above the L1\% compared to the other projects, but this would not be true of all regions of the turbine. The $\mathrm{B} 2$ hub region is probably a worse passage route compared to the other projects and with mid-blade and tip regions being slightly better than most of the other projects. Fish distribution through the turbine will affect the survival rates of turbine-passed fish. From this comparative analysis, B2 bead passage runner performance is not substantially better (or worse) than the other projects. There are not any attributes that could be identified that could be transferred to other projects to improve fish passage conditions. Some of the B2 runner metrics or attributes are negative, such as operating at flattest blade angle and hub gap passage.

\section{Draft tube comparisons}

Draft tube LDV measurements were obtained for the projects listed in Table 3. The LDV measurements for each project were taken within each draft tube barrel as close to the draft tube exit as physically possible. The analysis methods performed with the LDV measurements (for each project as listed in Table 3) were the same as defined for the $\mathrm{B} 2$ project earlier in this report. The only exception is that the draft uniformity was not calculated for the McNary and Lower Granite Projects.

Plate 106 shows the flow split between each draft tube barrel plotted against turbine discharge for all projects in Table 3. As described earlier in the report, the flow split between the two B2 draft tube barrels is uneven throughout the operating range. This also occurs for all projects except 
McNary where the draft tube flow split is nearly even above $12,400 \mathrm{ft} 3 / \mathrm{s}$. When compared to the other projects, the B2 draft tube barrels flow disparities are nearly the largest throughout its operating ranges (at comparable discharges). More balanced flow between the draft tube barrels is thought to be beneficial for introducing fish into the tailrace. There is no indication from these data that the B2 draft design tube would perform better for providing balanced loading between the draft tube barrels than most of the other projects. Therefore, there is nothing in the B2 runner and draft tube design that would provide for balanced loading between the draft tube barrels.

The method for calculating the uniformity of flow within each draft tube barrel is defined earlier in this report. In addition to B2, the uniformity of flow for each draft tube barrel through its operating range was calculated for the B1, Ice Harbor, and John Day projects. The uniformity of flow for each draft tube barrel was weighted by its barrel flow. The weighted uniformity of flow for the two barrels was then combined into one overall draft tube uniformity of flow metric. This was done at each operating point tested for each of the four projects. The overall draft tube uniformity of flow was plotted against the turbine loading at each operating for the four projects (Plate 107). B2 draft tube uniformity of flow through its operating range is very similar to the other three projects (at comparable discharges) with the exception at the B2 Peak operating where B2 is a little better, but the B2 draft tube uniformity of flow is not better than the other projects at all comparable points.

The method for calculating the draft tube barrel turbulence intensity has been defined previously in this report. The turbulence intensity was calculated for both draft tube barrels at several operating points for each of the projects listed in Table 3. The turbulence intensity calculated for each draft tube barrel for each operating point was weighted for its respective draft tube barrel flow. The two weighted draft tube barrel turbulence intensities were combined into one overall draft tube turbulence intensity value. This was done for each operating point for all projects. The overall draft tube turbulence intensity vs. turbine loading for all projects is provided in Plate 108. In examining this plot, it can be seen that B2 turbulence intensity values are in the middle of the other five projects throughout the B2 operating range (at comparable turbine loadings). B2 runner and draft tube designs do not provide draft tube exit turbulence intensity values that would be desirable to transfer to other projects. 


\section{Egress comparisons}

Egress evaluations were conducted for the B2, B1, and Ice Harbor Projects. Egress experiments for these three projects were conducted utilizing the methods and techniques outlined previously in this report. The only exception to this is the distance downstream of the draft tube exit used for egress evaluations. An amount of 175 prototype $\mathrm{ft}$ was used for B1 compared to $200 \mathrm{ft}$ for $\mathrm{B} 2$ and Ice Harbor.

A plot of percentage of beads entrained into the back roll vs. turbine loading evaluated for the three projects can be seen in Plate 109. At B2 L1\% discharge level, the number of beads entrained into the backroll was lowest for B1 and highest for Ice Harbor with B2 backroll performance between the two projects. The percentage of beads entrained into the backroll at GenL for B2 was very low (performed well). The egress upper discharge evaluated for $\mathrm{B} 1$ and Ice Harbor were substantially lower than B2 GenL, and therefore the B2 GenL performance cannot be directly compared to the B1 and Ice Harbor projects at this operating point.

Beads passage time from the draft tube exit to a point $200 \mathrm{ft}$ downstream of the draft tube exit obtained for the B2 egress evaluation was compared to egress evaluation results for Ice Harbor and B1 projects (Plate 110). Longer passage times indicate potentially more exposure to predation in the tailrace immediately downstream of the draft exit. B2 had significantly longer passage times compared to both B1 and Ice Projects at its L1\%. Bead passage time for $\mathrm{B} 2$ was low at the $\mathrm{B} 2 \mathrm{GenL}$.

The minimum depth was recorded for each test bead in the egress evaluation zone at the $\mathrm{B} 2 \mathrm{~L} 1 \%$ and GenL operating points. The minimum depths for all beads were averaged for each operating point. The same procedure was performed for operating points for the B1 and Ice Harbor projects. A graphical comparison of the three projects is shown in Plate 111. Deeper average tailrace depths for turbine-passed fish may allow for better avoidance of predators in the tailrace region. Average bead passage depths where slightly higher at the B2 L1\% compared to B1 and significantly higher compared to Ice Harbor (at comparable turbine loadings). The $\mathrm{B} 2$ GenL operating point turbine loading is significantly higher than the other two projects and therefore cannot be directly compared to other projects, but B2 average minimum bead passage depth was slightly higher (worse) at the B2 GenL compared to the B2 L1\% operating point. 
In addition to the average minimum depth of beads passing through the evaluation zone, the percentage of beads passing within $5 \mathrm{ft}$ of water surface is also a metric that may be important when comparing the three projects. The graphical comparison of the three projects for this metric is provided in Plate 112. At the Ice Harbor Project, a very significant percentage of beads came within 5 prototype $\mathrm{ft}$ of the water surface throughout its operating range. B2 performed much better than Ice Harbor at its L1\% operating point but had somewhat higher percentage than B1 (at similar turbine loadings). The B2 GenL operating point turbine loading is significantly higher than the other two projects and therefore cannot used to compare minimum depth passage metric. The percentage of beads passing within $5 \mathrm{ft}$ of the water surface in the evaluation zone was lower at the $\mathrm{B} 2$ GenL operating point compared to the $\mathrm{B} 2 \mathrm{~L} 1 \%$ percentage.

\section{Project comparisons conclusions}

There are many geometric and operational metrics that can be compared between projects. Some are head, runner speed, runner diameter, number of runner blades, turbine discharge, turbine water velocity, draft tube exit configuration, tailrace geometry, tailrace water depth, intake screens, length of screens, etc. Some would logically seem to be better for fish, some would be trade-offs, and for some it is just not known what would be better for fish. In addition, other metrics are very important for comparing the projects, but project data for these metrics are incomplete (pressure, depth acclimation, fish distribution through the runner, etc.).

In comparing the physical attributes of the projects, there are several desirable features of the B2 Project. Some of these features are large runner diameter, five-bladed runner, low runner speed, shaped stay vane leading edges, flat draft tube invert exit angle, flat draft tube roof exit angle, deep tailrace, and confined tailrace channel.

Overall, the stay vane bead data project evaluation comparisons do not show significant differences in performance between B2 and the other projects throughout its operating range. It did perform a little better for shear at higher turbine loadings, which does indicate a shaped stay vane design should provide for smoother flow through the stay vane cascade.

The runner performance of B2 (comparisons to the other five projects) indicates that B2 comparable performance depends on the region of passage and operating points being compared. The hub area is much 
worse for bead passage regarding blade contact for B2. However, overall from the project comparisons, there is not any aspect of the B2 turbine design that performs marginally better than all of the other projects turbine designs. As discussed earlier, the turbines have different rotational speeds, different diameter runners, different turbine water velocities for similar discharges, and varying tangential blade speeds. Thus, it is difficult to make direct comparisons between ERDC bead evaluations of different projects. Different projects have different screening devices, and B2 intake geometry and approach topography are significantly different compared to the other projects, which will affect distribution of fish entering the turbine. The distribution of fish entering the turbine will dictate the level of injury to fish passing through the turbine. For example, if all fish pass through the mid-blade region, then the blade-to-fish interaction should be at its minimum value compared to other turbine region passage.

Comparisons of metrics of draft tube evaluations for B2 such as draft tube barrel split, draft tube barrel flow intensities, and uniformity of flow were compared to the five other USACE projects. B2 draft tube and runner did not provide better draft tube flow attributes compared to the other projects. Therefore, there were not any B2 design features of the runner or draft tube that could be transferred to other USACE projects to improve flow within the draft tube.

Only limited data could be compared from B2 egress evaluations to the other USACE projects. Results for B2 indicate that the egress should be better as discharge is increased. Comparing B2 to two other USACE projects at $\mathrm{B} 2 \mathrm{~L} 1 \%$ indicated that $\mathrm{B} 2$ provides for average rates of bead entrainment into the backroll, but backroll rates were very low for B2 at GenL. Also, time passage of the beads from the draft tube exit to 200 or $150 \mathrm{ft}$ downstream was highest for B2 at L1\% compared to the other two USACE projects but was much lower at the $\mathrm{B} 2 \mathrm{GenL}$. Other metrics compared indicate the B2 egress performs nearly as well and in some cases better than the other two projects. Overall egress conditions for B2 appear to be somewhat better for B2 compared to the other two projects and performs well at GenL. The better overall performance can probably be attributed to the flat invert and roof of the B2 draft tube at its exit with high discharges and a relatively deep tailrace (at $55 \mathrm{ft}$ head). As pointed out earlier in this report, projects operations will affect tailrace conditions, and the ERDC evaluations cannot address this. 


\section{References}

Bell, M. C., A. C. DeLacy, and G. J. Paulik. 1967. A Compendium on the Success of Passage of Small Fish through Turbines. U.S. Army Corp of Engineers, North Pacific Division.

Bell, M. C. 1981. Recommendation for Turbine Generator Loadings and Blade Gate Relationships for the Best Survival of Juvenile Migrants at the Eight Columbia Basin Dams Operated by the Corps of Engineers. Prepared for the U.S. Army Corps of Engineers, Portland, OR, Portland District.

Bell, M. C. 1986. Fisheries Handbook of Engineering Requirements and Biological Criteria. Fish Passage Development and Evaluation Program. Portland, OR: U.S. Army Corps of Engineers, North Pacific Division.

Davidson, R. A. 2017. Bonneville First Powerhouse ERDC Turbine Operating Range Investigation. ERDC/CHL TR-17-9. Vicksburg, MS: U.S. Army Engineer Research and Development Center.

Fisheries, National Oceanic and Atmospheric Administration (NOAA). 2000. Endangered Species Act-Section 7, Consultation: Biological Opinion; Reinitiation of Consultation on Operation of the Federal Columbia River Power System, Including the Juvenile Fish Transportation Program, and 19 Bureau of Reclamation Projects in the Columbia Basin. December 21, 2001. Northwest Region, Seattle, WA. https://catalog.princeton.edu/catalog/5365333.

Fisheries, National Oceanic and Atmospheric Administration (NOAA). 2004. Endangered Species Act - Section 7 Consultation Biological Opinion. Consultation on Remand for Operation of the Columbia River Power System and 19 Bureau of Reclamation Projects in the Columbia Basin [revised and reissued pursuant to court order, NWF v. NMFS, Civ. No. CV 01-640-RE (D. Oregon)]. Northwest Region, Seattle, WA.

Fisheries, National Oceanic and Atmospheric Administration (NOAA). 2008. Biological Opinion - Consultation on Remand for Operation of the Federal Columbia River Power System, 11 Bureau of Reclamation Projects in the Columbia Basin and ESA Section 1O(a)(1)(A) Permit for Juvenile Transportation Program. National Marine Fisheries Service (NOAA Fisheries). Northwest region. Seattle, WA.

Normandeau Associates Inc. 200o. Direct Survival and Condition of Juvenile Chinook Salmon Passed through an Existing and New Minimum Gap Runner Turbines at Bonneville Dam First Powerhouse, Columbia River. Drumore, PA: Normandeau Associates.

Skalski, J. R. 2006. Characterization of Sampling Precision and Sample Size Requirements for Bead Strike Trials. Report prepared for Engineer Research and Development Center - documented in ERDC/CHL TR-17-9. Columbia Basin Research School of Aquatic and Fishery Sciences, University of Washington, Seattle, WA. 
U.S. Army Corps of Engineers (USACE). 2004. Turbine Survival Program (TSP): Phase 1 Report: 1997-2003. Portland, OR: U.S. Army Corps of Engineers, Northwest Division.

USACE. 2011. Fish Passage Plan, Corps of Engineers Projects. Portland, OR: U.S. Army Corps of Engineers, Northwest Division.

USACE. 2013. Turbine Optimization for Passage of Juvenile Salmon at Hydropower Projects on the Columbia and Lower Snake Rivers. Phase II Main Report. Washington, DC: U.S. Army Corp of Engineers. https://www.salmonrecovery.gov/Files/APR/Section\%202\%20Literature\%20Cited/ACOE\%2020 13a_TSP-Phase-II-Main-Report.pdf. 


\section{Bonneville 2nd Powerhouse ERDC Turbine Model}

Model Inflow Meter 1 Calibration

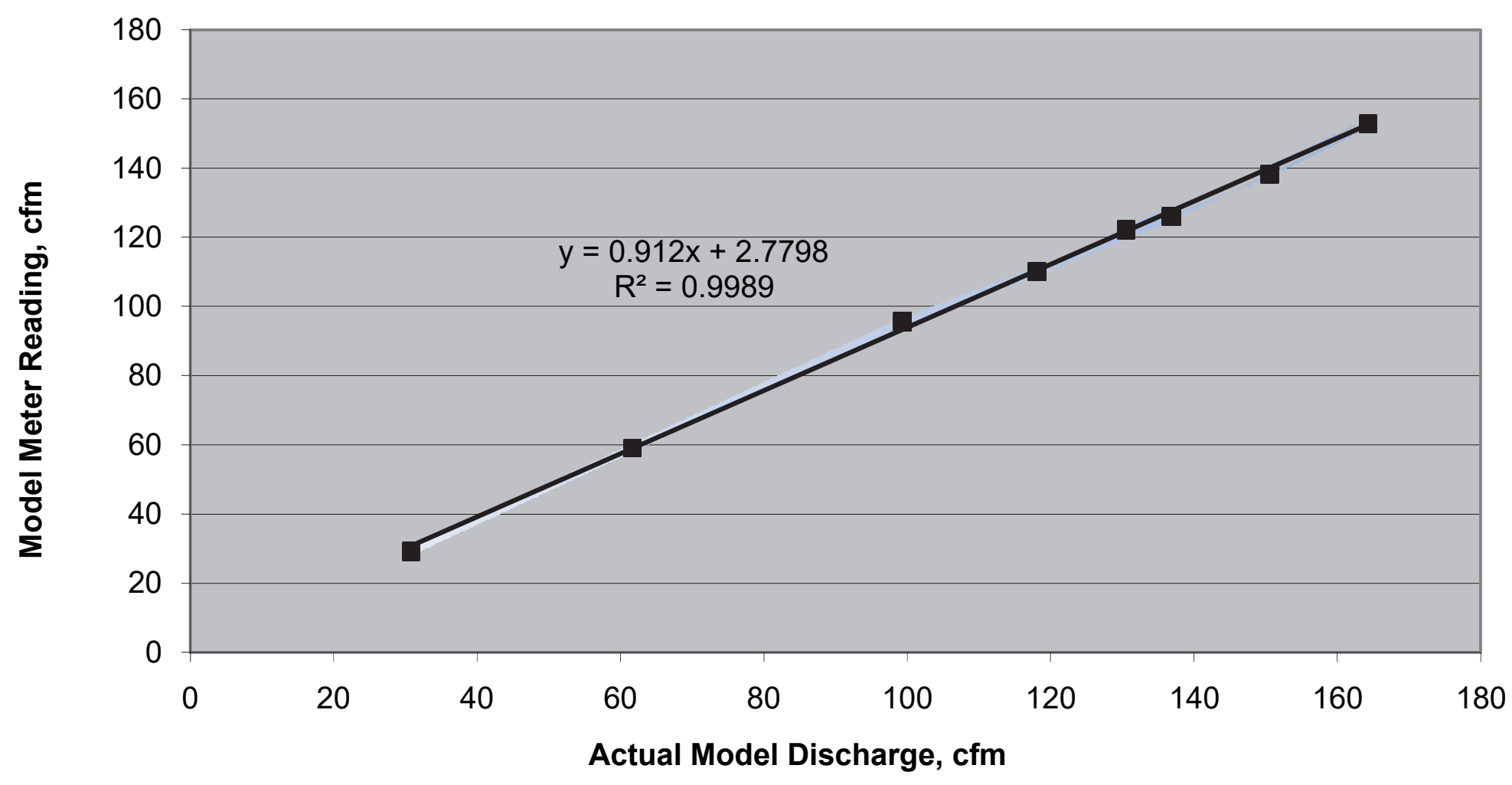




\section{Bonneville 2nd Powerhouse ERDC Turbine Model}

Model Inflow Meter 2 Calibration

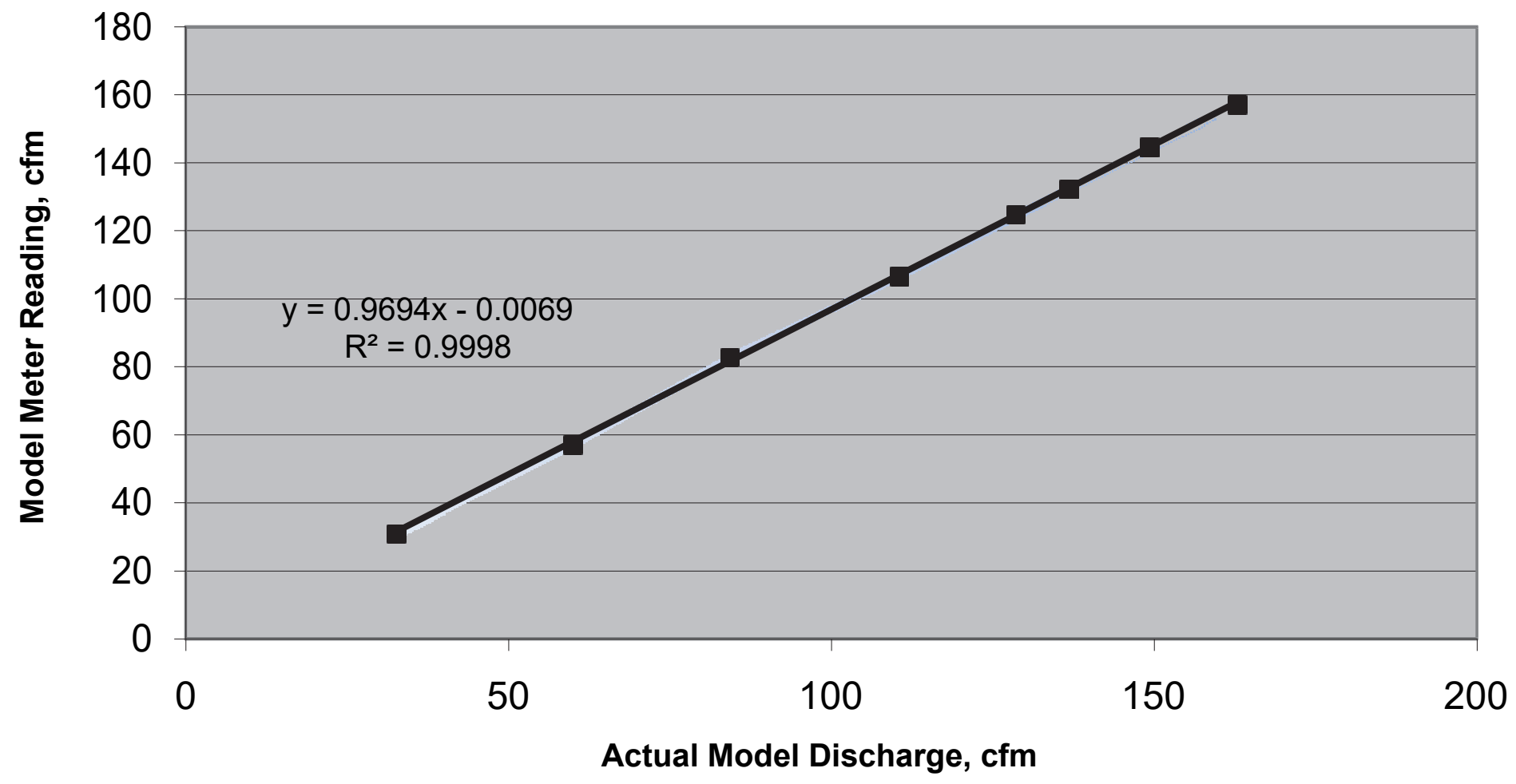




\section{Bonneville 2nd Powerhouse ERDC Turbine Model}

Model Inflow Meter 3 Calibration

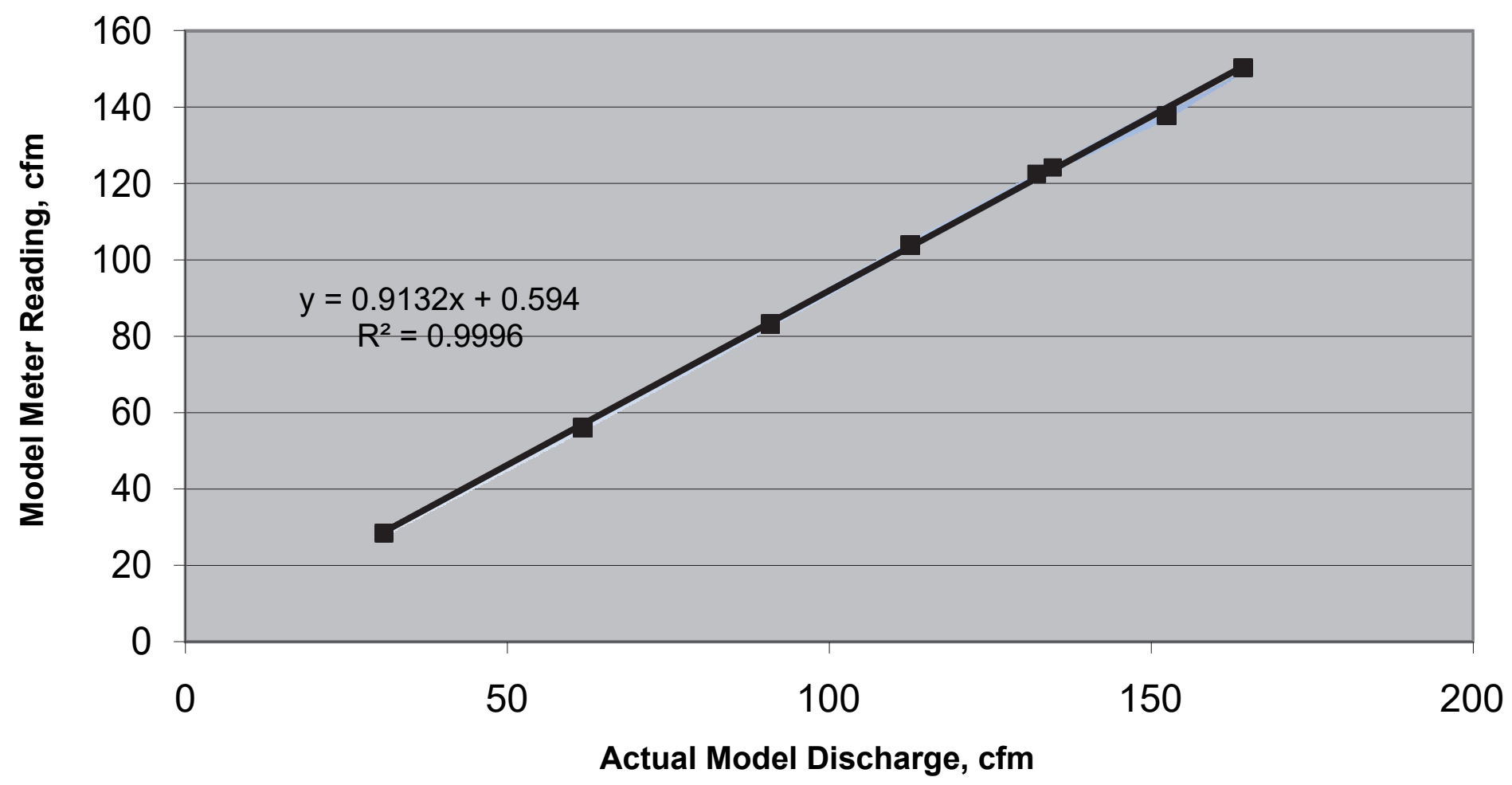




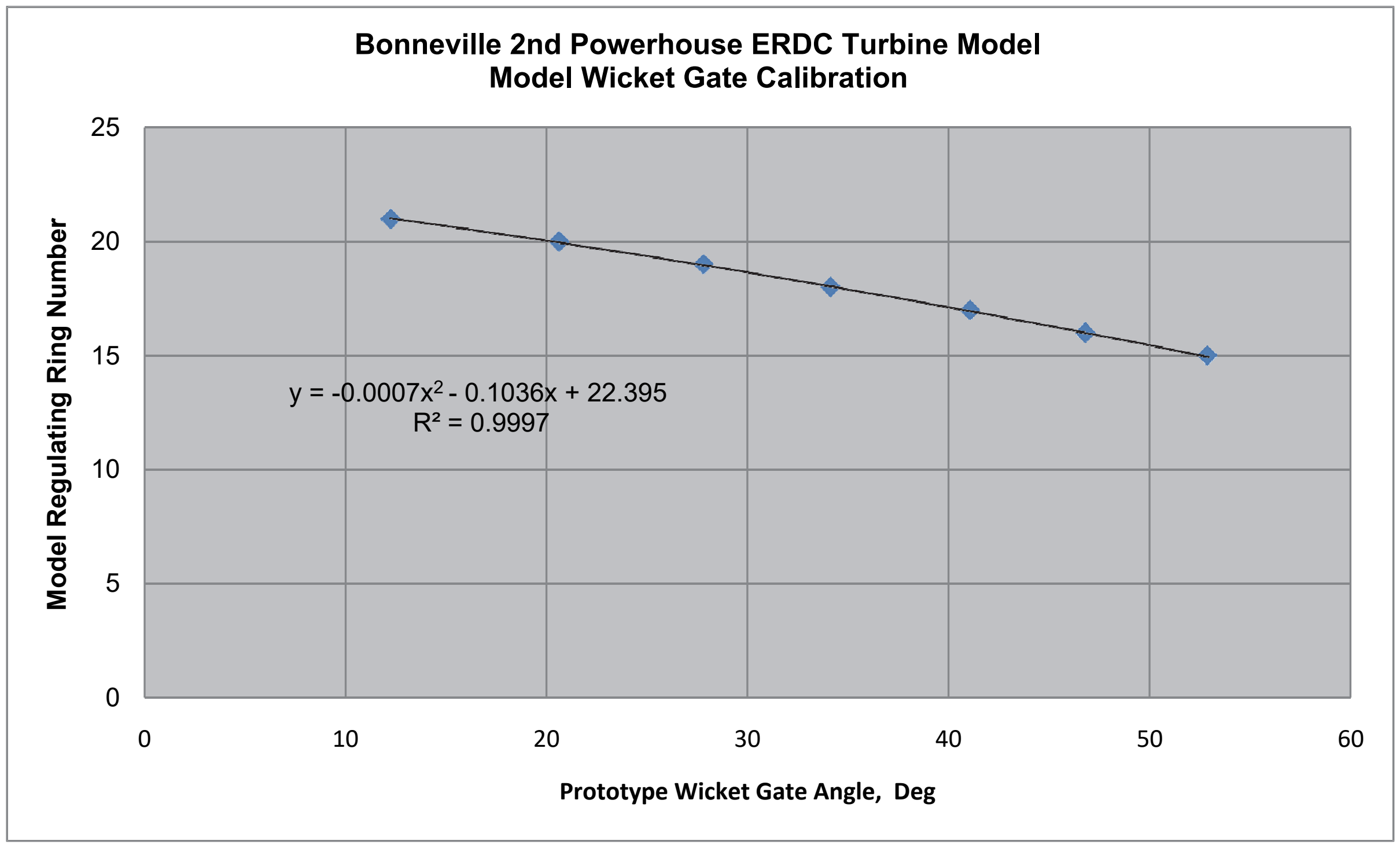




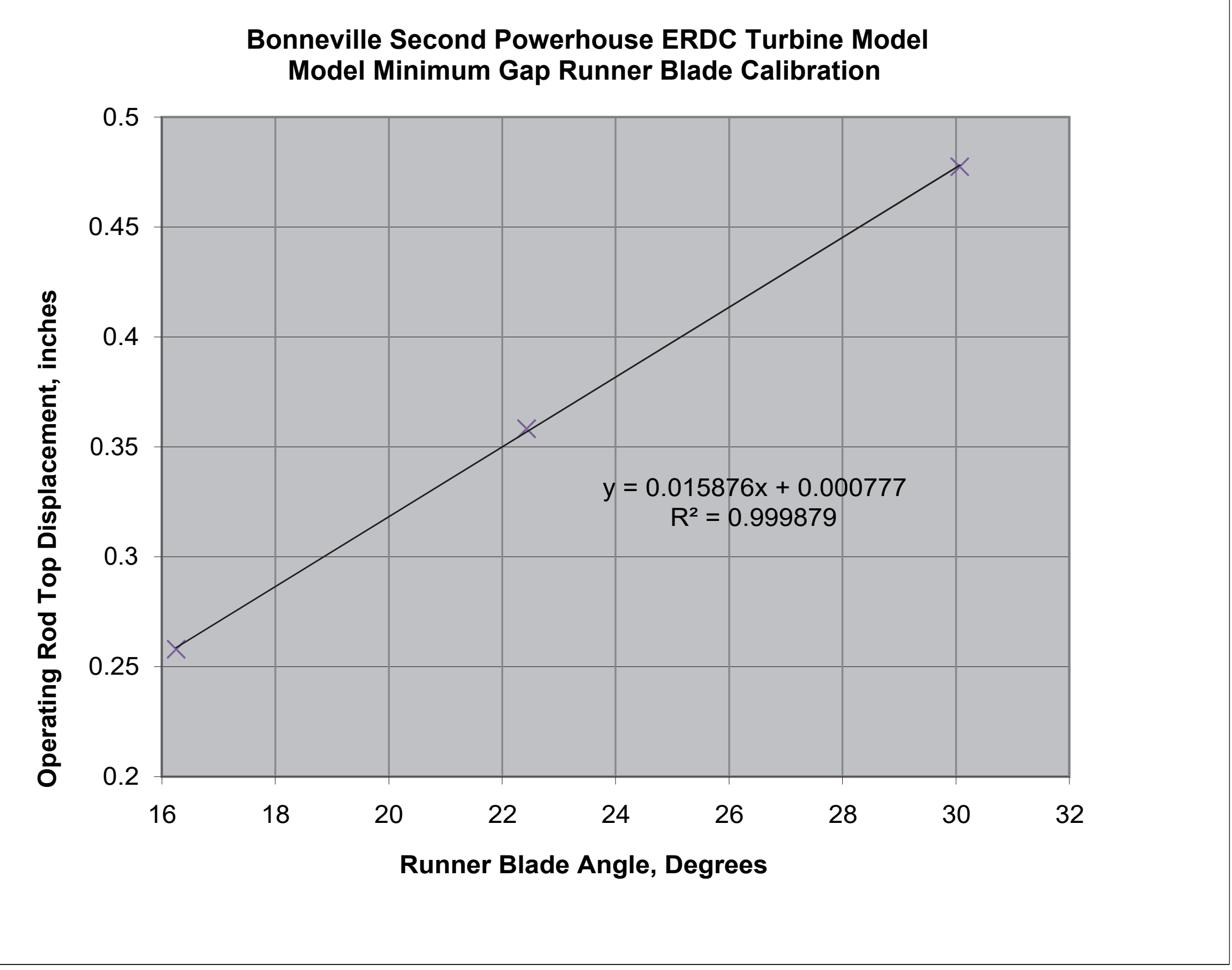




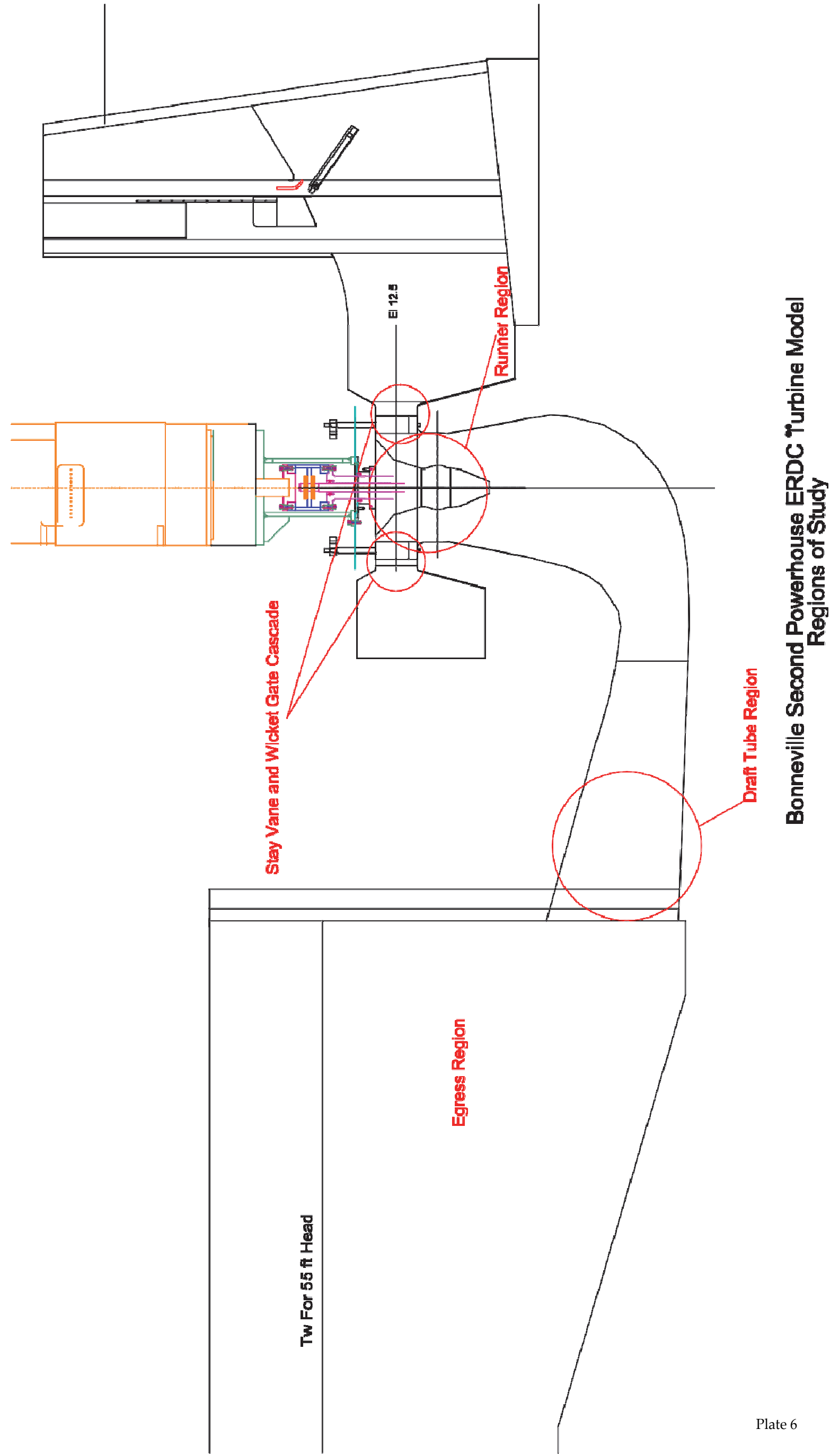



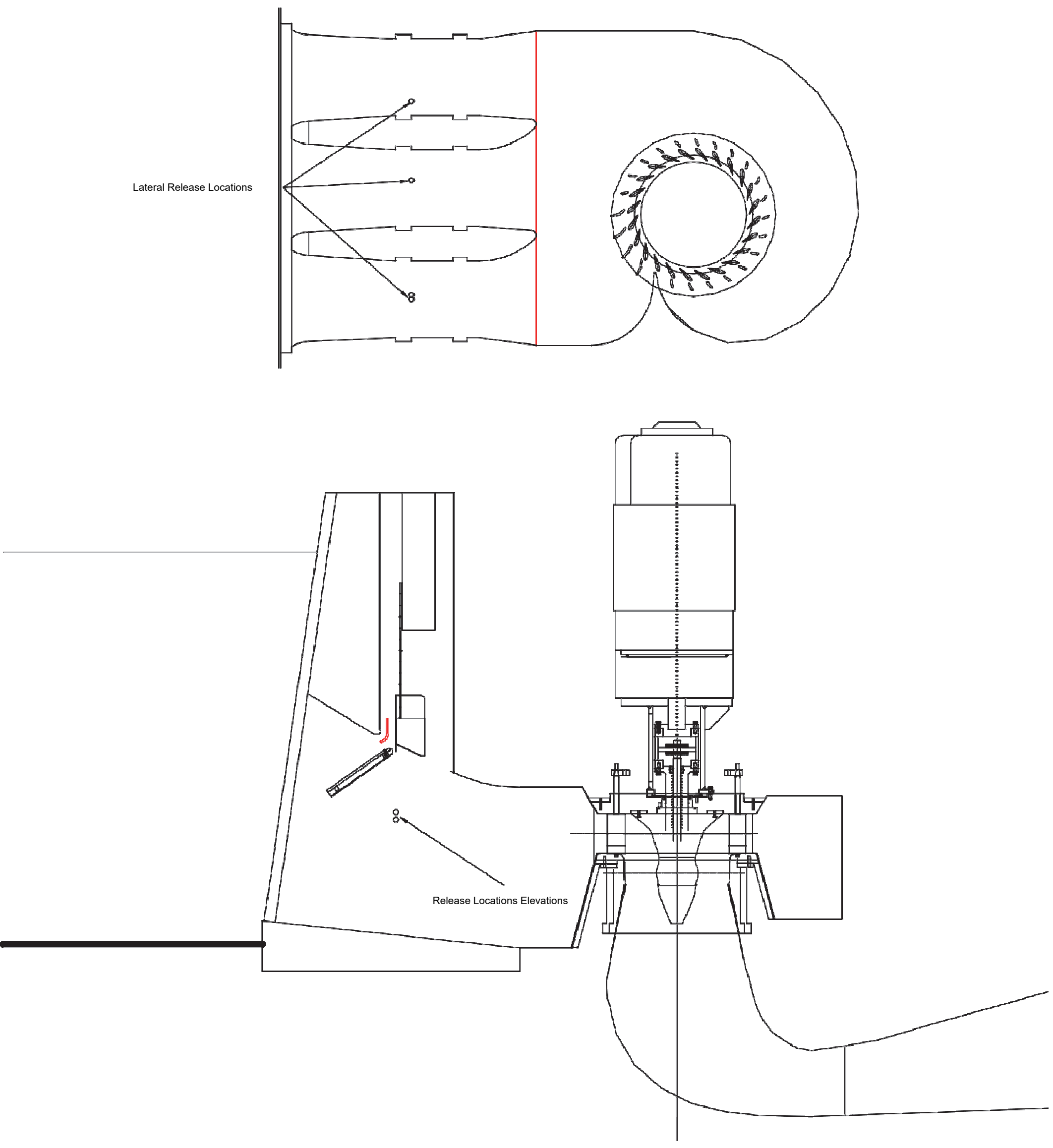


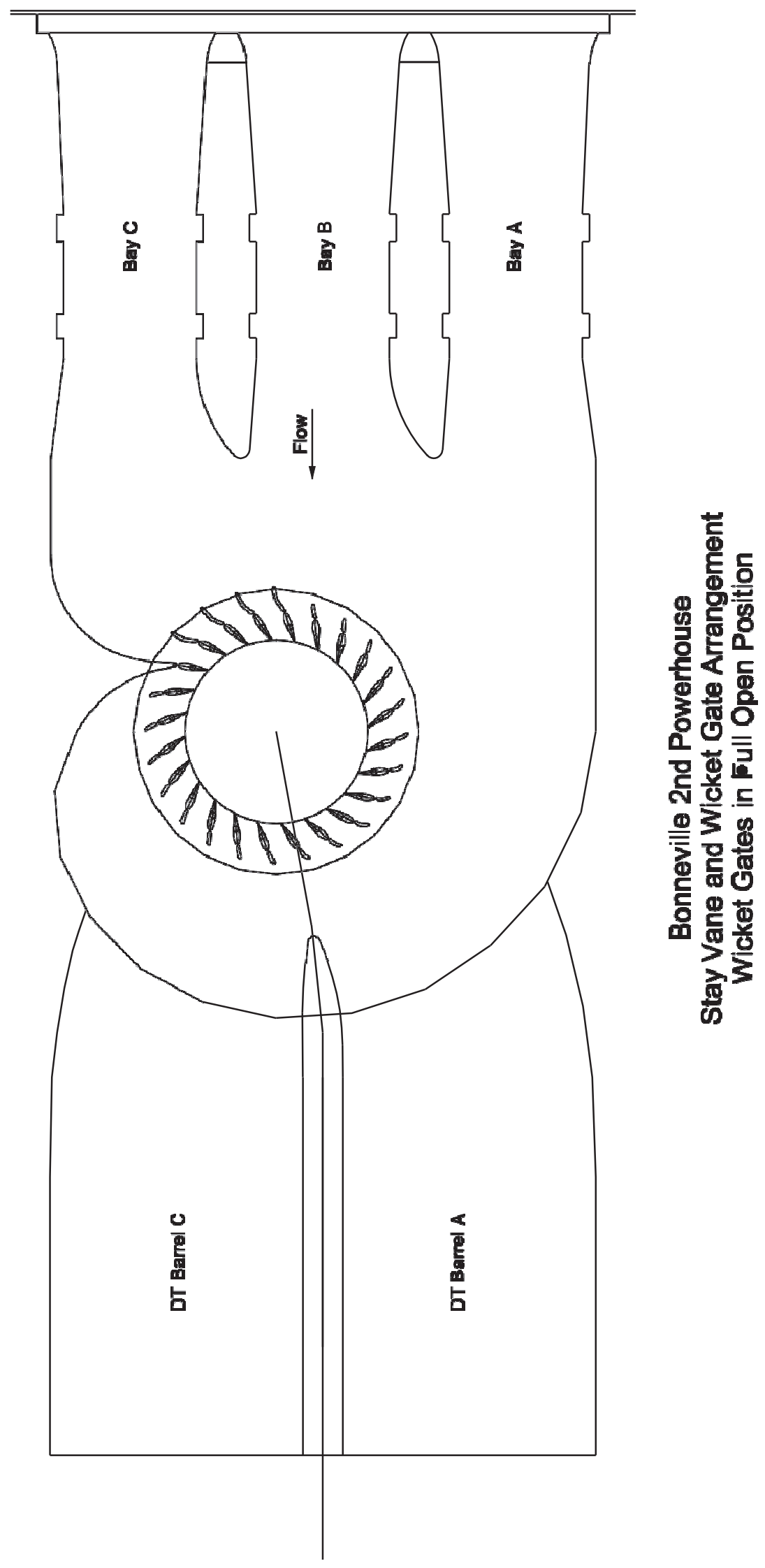

Plate 8 

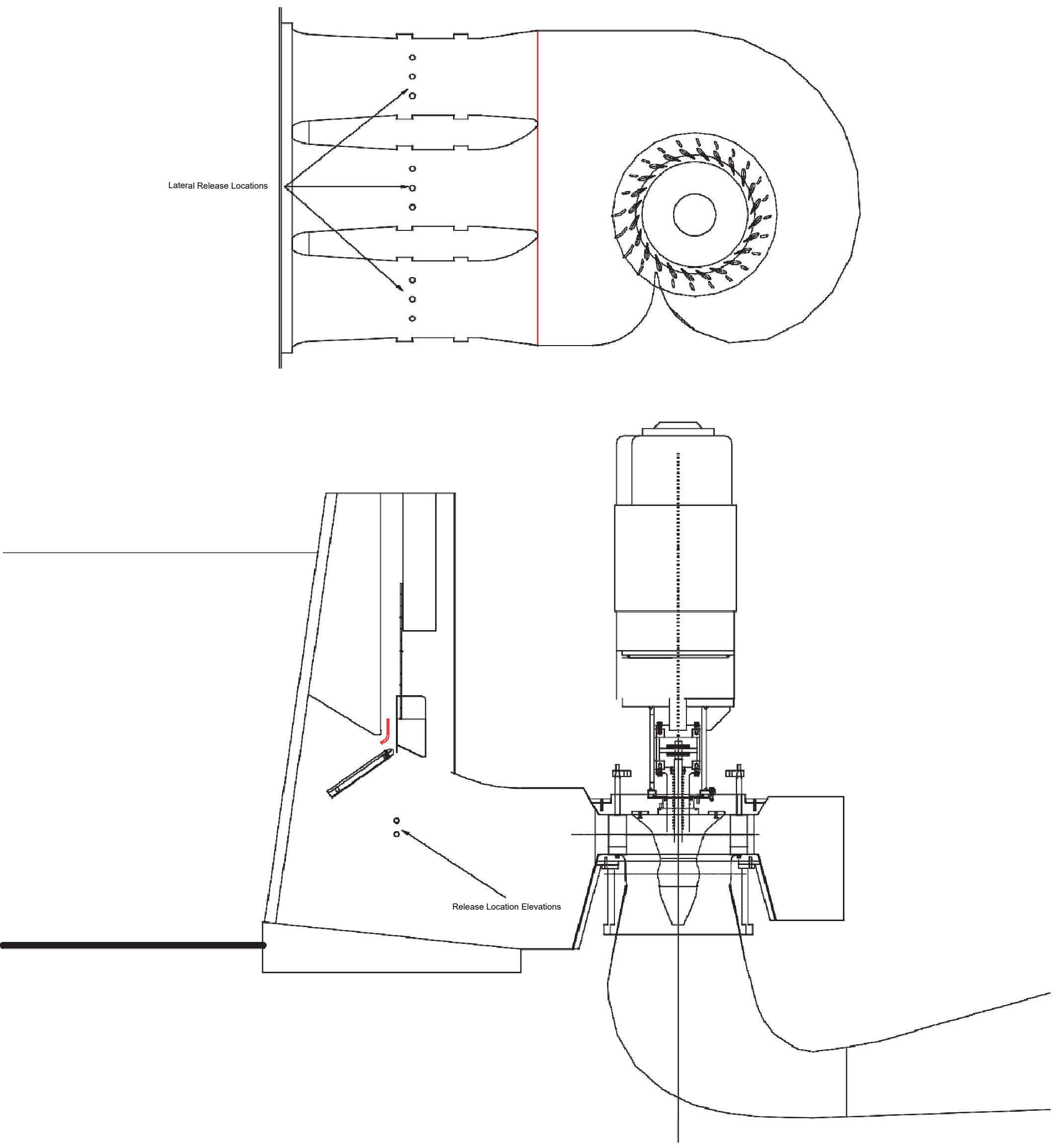

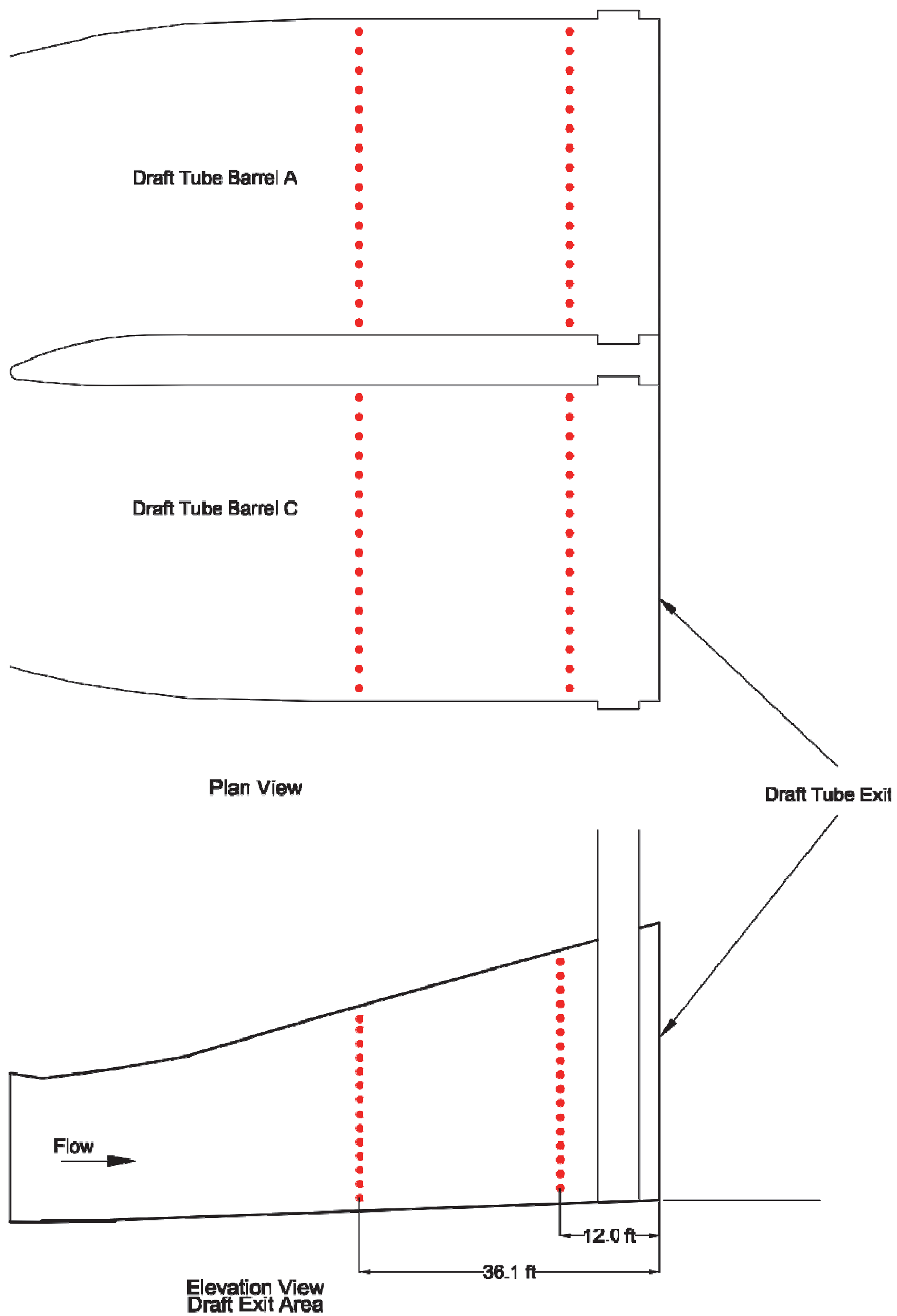

Bonneville 2nd Powerhouse ERDC Turbine Model 
Bonneville 2nd Powerhouse

ERDC Turbine Model

Stay Vane Contact Bead Passage Results 55 FT Head

\begin{tabular}{|l|c|c|c|c|c|c|c|c|c|}
\hline $\begin{array}{c}\text { Operation } \\
\text { Point }\end{array}$ & $\begin{array}{c}\text { Target } \\
\text { Discharge, } \\
\text { Cfs }\end{array}$ & $\begin{array}{c}\text { Blade } \\
\text { Angle, deg }\end{array}$ & $\begin{array}{c}\text { Wicket Gate } \\
\text { Angle, Deg }\end{array}$ & $\begin{array}{c}\text { Contact } \\
\text { Score }\end{array}$ & $\begin{array}{c}\text { Contact } \\
\text { Stdev }\end{array}$ & $\begin{array}{c}\text { contact } \\
\text { 1's and } \\
\text { 2's }\end{array}$ & $\begin{array}{c}\text { Standard } \\
\text { error }\end{array}$ & $\begin{array}{c}95 \% \\
\text { Confidence } \\
\text { interval }\end{array}$ & $\begin{array}{c}\# \text { of } \\
\text { Beads }\end{array}$ \\
\hline L1\% & 11,280 & 16.5 & 33.1 & 5.61 & 1.03 & 3.8 & 0.52 & 1.01 & 1371 \\
\hline Peak & 14,925 & 20.3 & 39.1 & 5.68 & 0.92 & 2.8 & 0.44 & 0.86 & 1409 \\
\hline GenL & 19,115 & 26.5 & 45.9 & 5.78 & 0.79 & 2.3 & 0.40 & 0.79 & 1372 \\
\hline
\end{tabular}

Bonneville 2nd Powerhouse

ERDC Turbine Model

Stay Vane Contact Bead Passage Results

55 FT Head

\begin{tabular}{|c|c|c|c|c|c|c|c|c|c|c|c|c|}
\hline $\begin{array}{c}\text { Operation } \\
\text { Point }\end{array}$ & $\begin{array}{c}\text { Target } \\
\text { Discharge, } \\
\text { Cfs }\end{array}$ & $\begin{array}{c}\text { Blade } \\
\text { Angle, deg }\end{array}$ & $\begin{array}{c}\text { Wicket } \\
\text { Gate } \\
\text { Angle, Deg }\end{array}$ & $\begin{array}{c}\text { Change } \\
\text { Direction } \\
\text { Score }\end{array}$ & $\begin{array}{c}\text { Change } \\
\text { Direction } \\
\text { Stdev }\end{array}$ & $\begin{array}{c}\text { \% Severe } \\
\text { Change } \\
\text { Direction } \\
1 \text { 's }\end{array}$ & $\begin{array}{c}\text { Standard } \\
\text { error }\end{array}$ & $\begin{array}{c}95 \% \\
\text { Confidence } \\
\text { interval }\end{array}$ & $\begin{array}{c}\% \text { Change } \\
\text { Direction 1's } \\
\text { and 2's }\end{array}$ & $\begin{array}{c}\text { Standard } \\
\text { error }\end{array}$ & $\begin{array}{c}95 \% \\
\text { Confidence } \\
\text { interval }\end{array}$ & $\begin{array}{c}\text { \# of } \\
\text { Beads }\end{array}$ \\
\hline L1\% & 11,280 & 16.5 & 33.1 & 3.69 & 0.74 & 1.8 & 0.36 & 0.71 & 13.1 & 0.91 & 1.78 & 1371 \\
\hline Peak & 14,925 & 20.3 & 39.1 & 3.76 & 0.65 & 1.3 & 0.31 & 0.60 & 9.0 & 0.76 & 1.50 & 1409 \\
\hline GenL & 19,115 & 26.5 & 45.9 & 3.83 & 0.56 & 1.2 & 0.30 & 0.59 & 6.2 & 0.65 & 1.28 & 1372 \\
\hline
\end{tabular}

Bonneville 2nd Powerhouse

ERDC Turbine Model

Stay Vane Passage Bead Product Score Results

55 FT Head

\begin{tabular}{|l|c|c|c|c|c|c|c|c|}
\hline $\begin{array}{c}\text { Operation } \\
\text { Point }\end{array}$ & $\begin{array}{c}\text { Target } \\
\text { Discharge, } \\
\text { Cfs }\end{array}$ & $\begin{array}{c}\text { Blade } \\
\text { Angle, deg }\end{array}$ & $\begin{array}{c}\text { Wicket Gate } \\
\text { Angle, Deg }\end{array}$ & $\begin{array}{c}\text { Product } \\
\text { Score }\end{array}$ & $\begin{array}{c}\text { Product } \\
\text { Std Dev }\end{array}$ & $\begin{array}{c}\text { Product } \\
\text { Variance }\end{array}$ & $\begin{array}{c}\text { Gap } \\
\text { Passage, \% }\end{array}$ & \# of Beads \\
\hline L1\% & 11,280 & 16.5 & 33.1 & 21.38 & 6.14 & 37.72 & 6.6 & 1371 \\
\hline Peak & 14,925 & 20.3 & 39.1 & 21.93 & 5.46 & 29.83 & 2.9 & 1409 \\
\hline GenL & 19,115 & 26.5 & 45.9 & 22.56 & 4.64 & 21.56 & 1.9 & 1372 \\
\hline
\end{tabular}




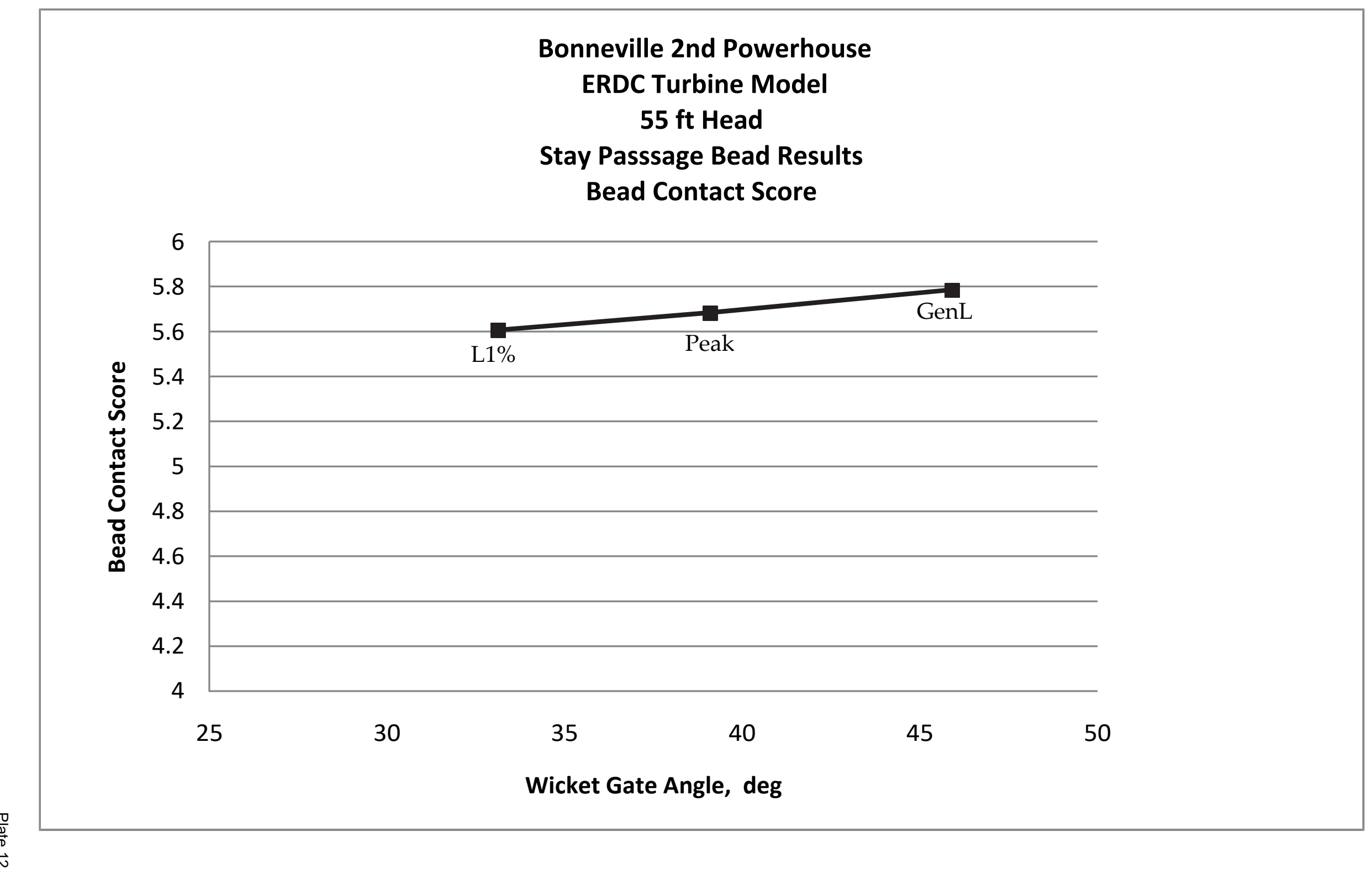




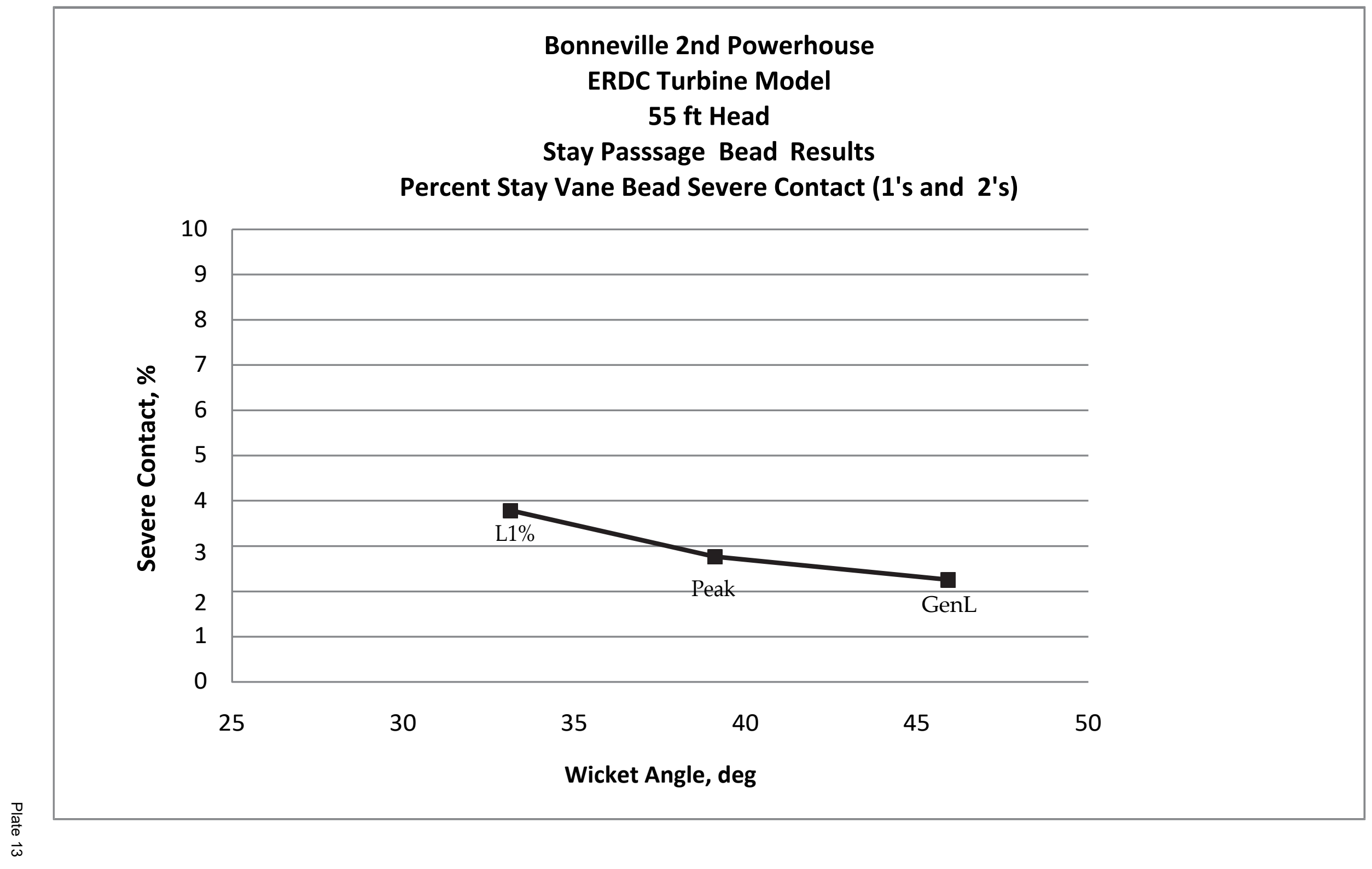




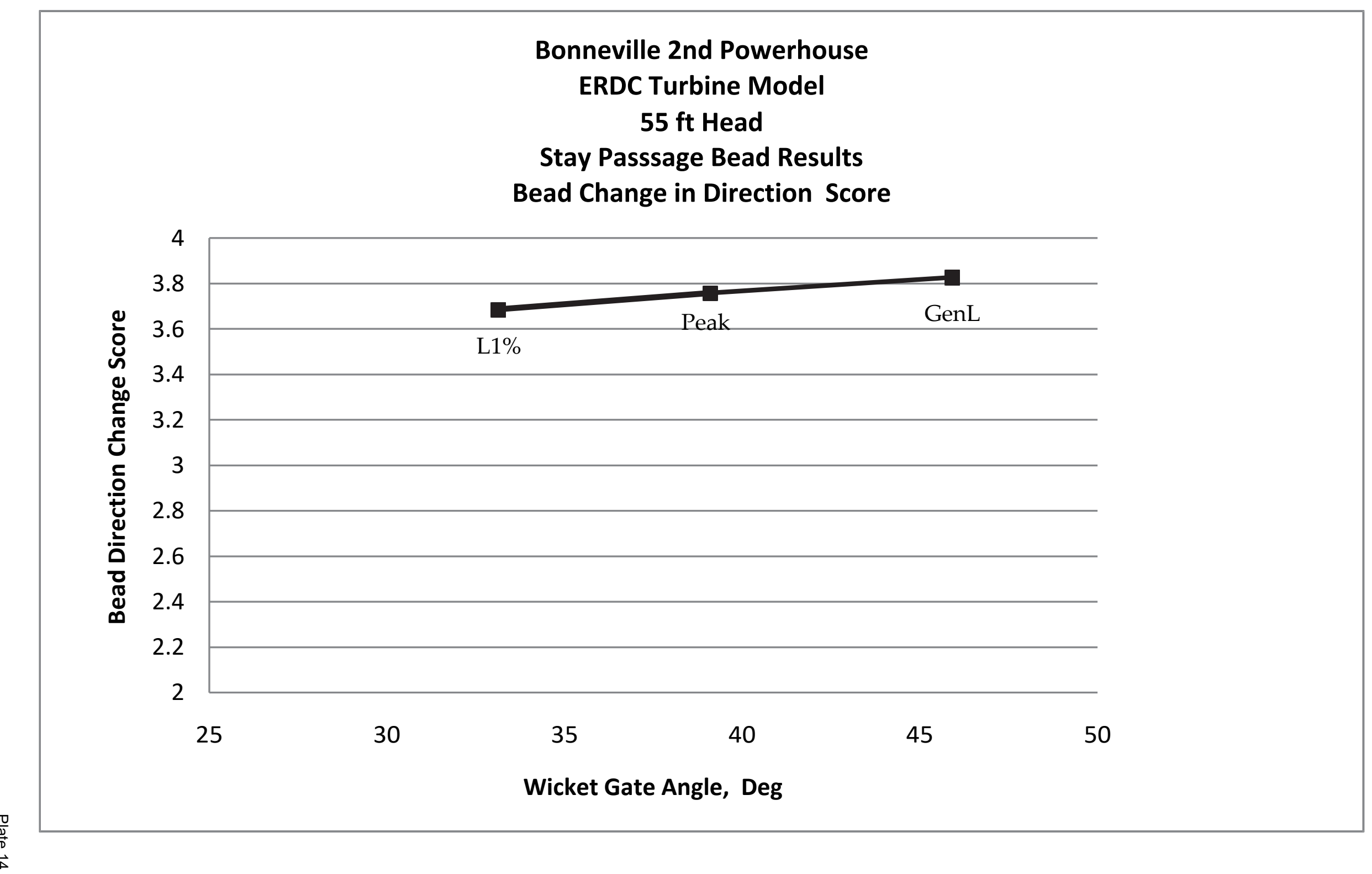




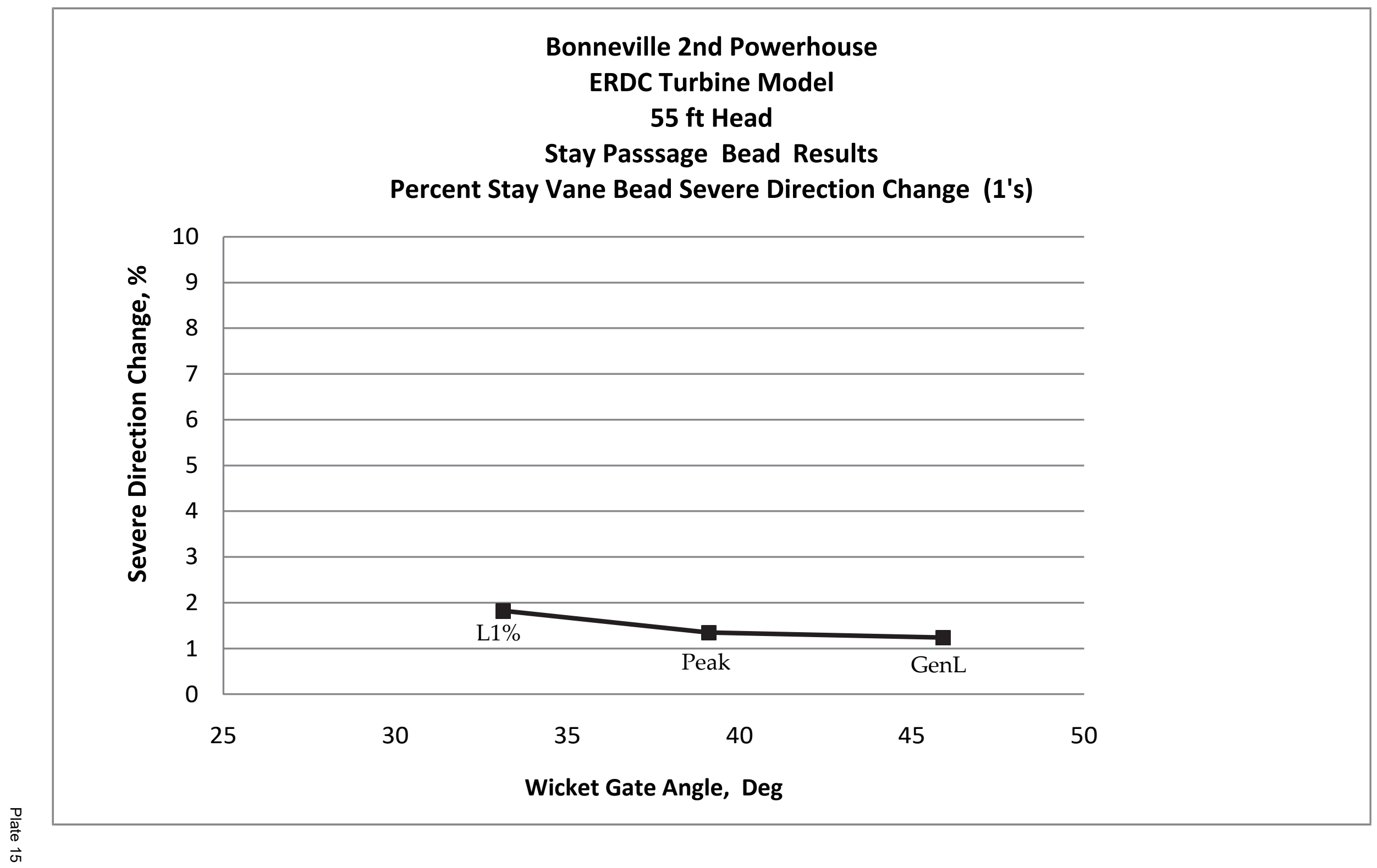




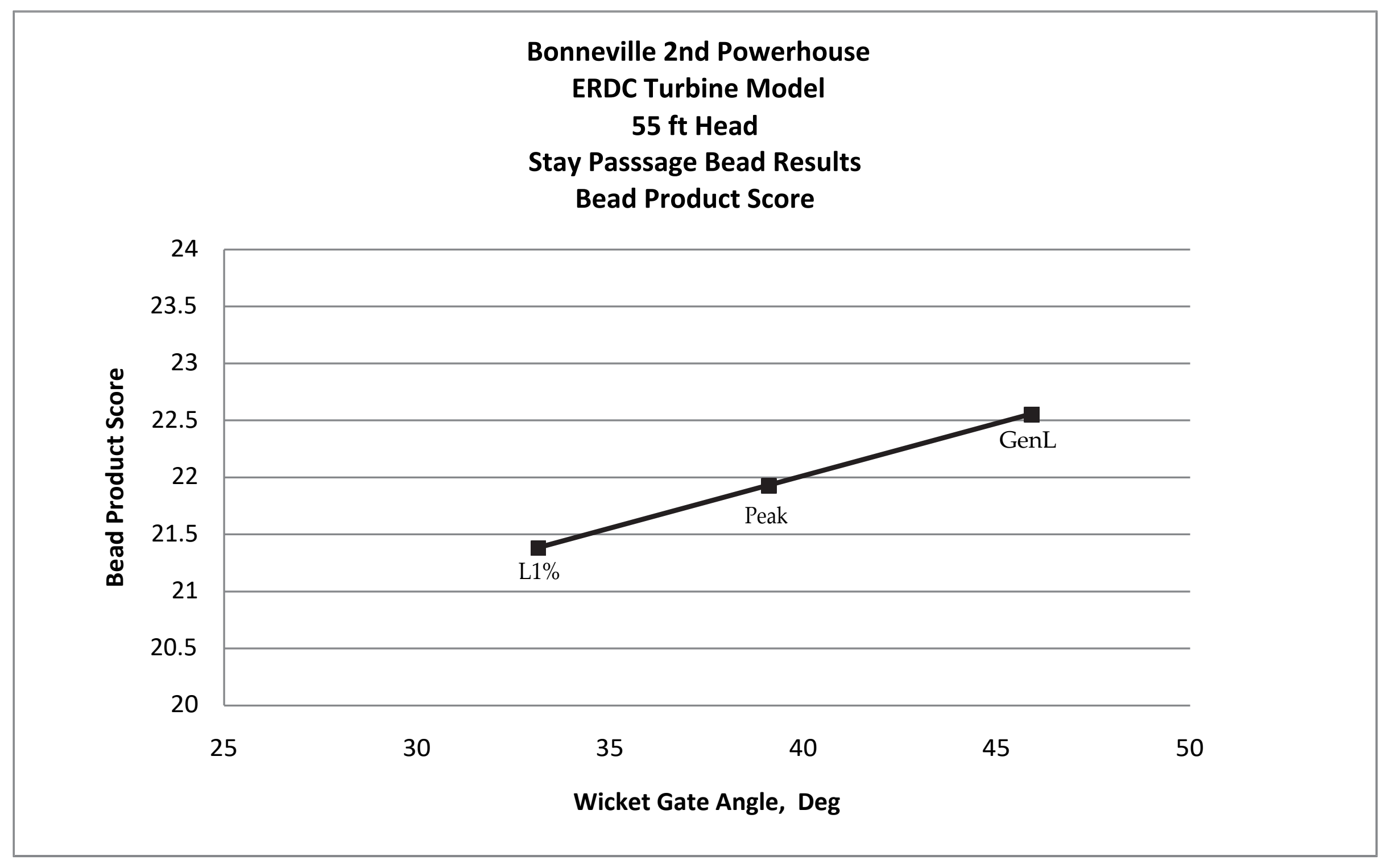




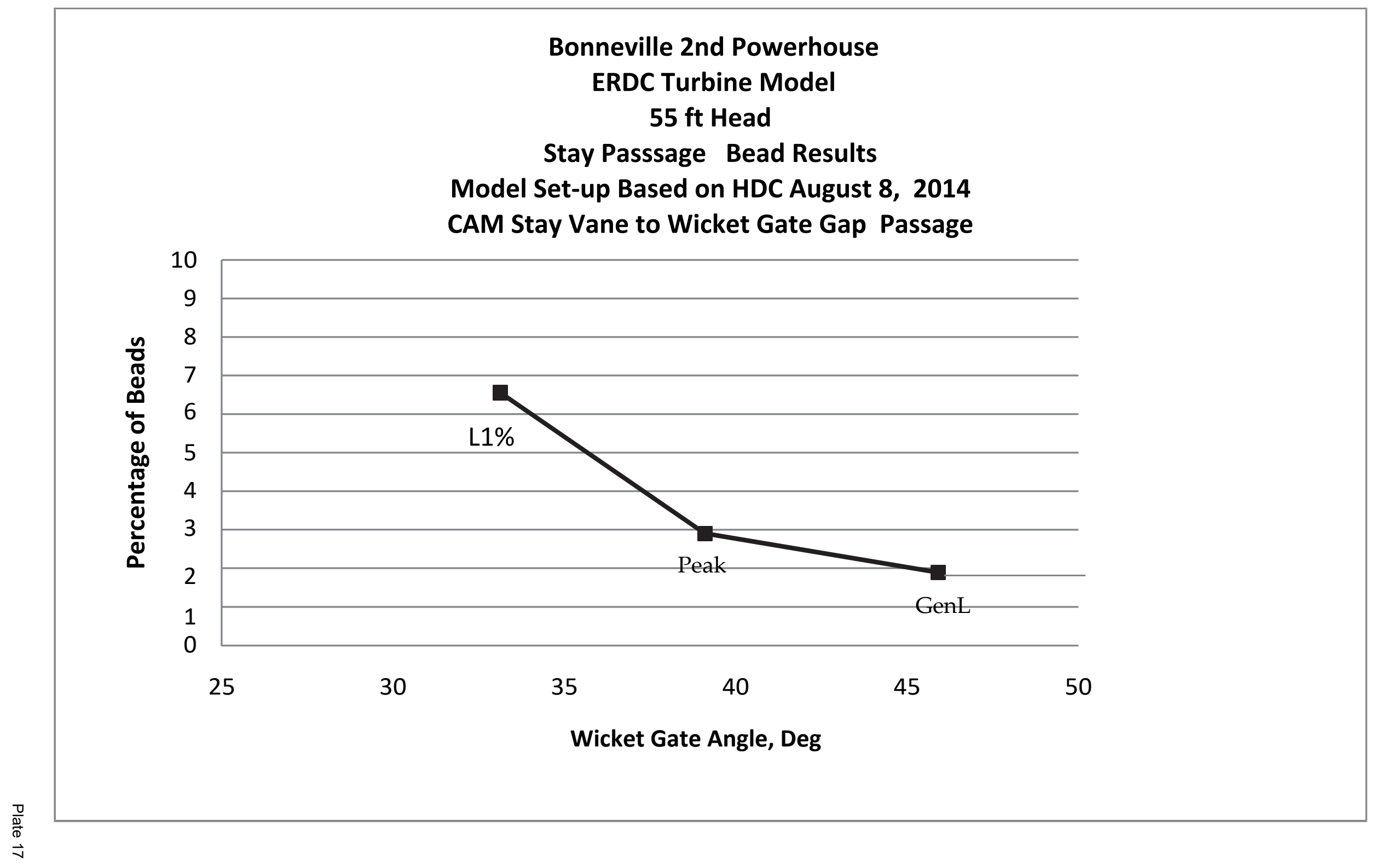




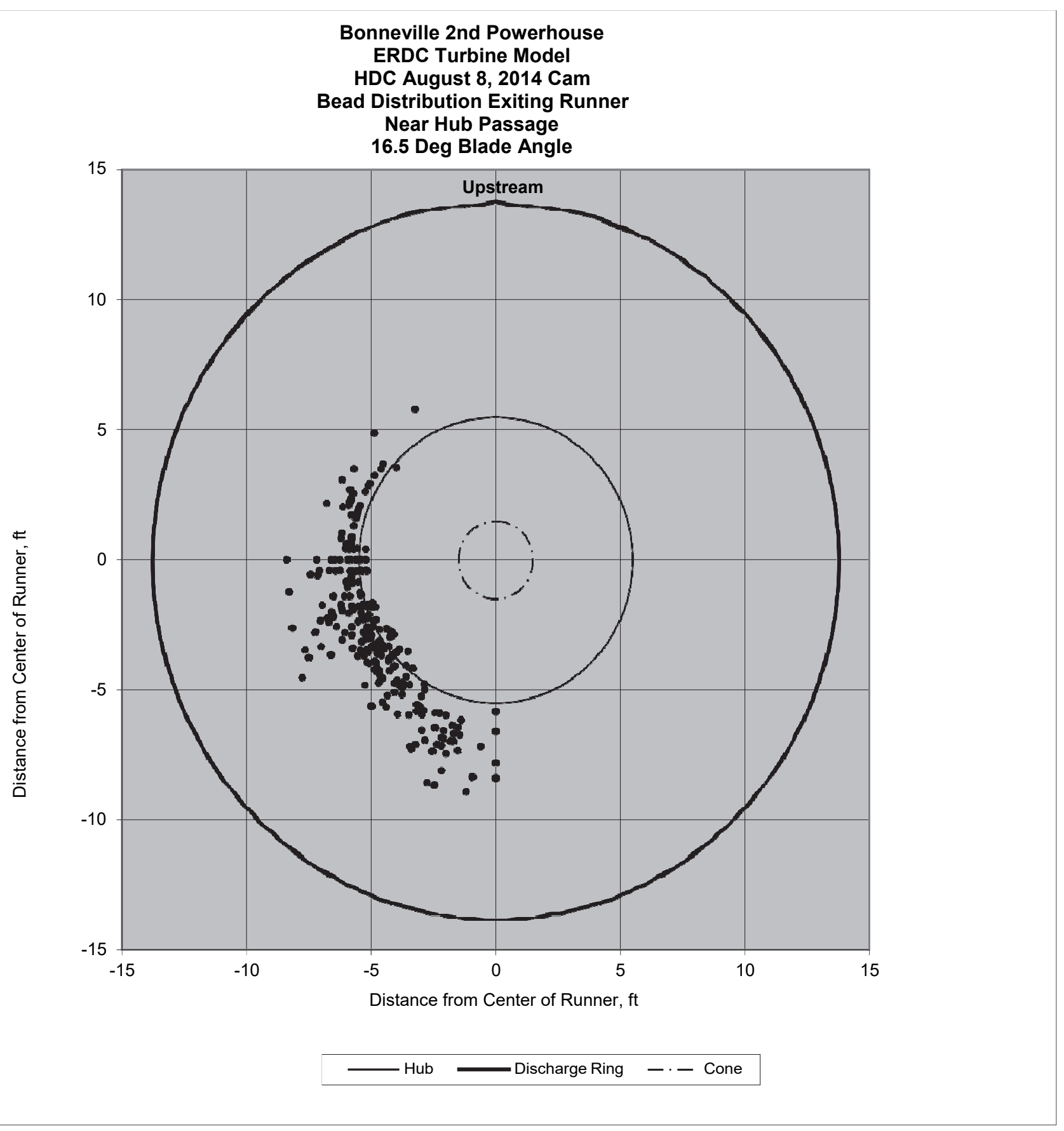




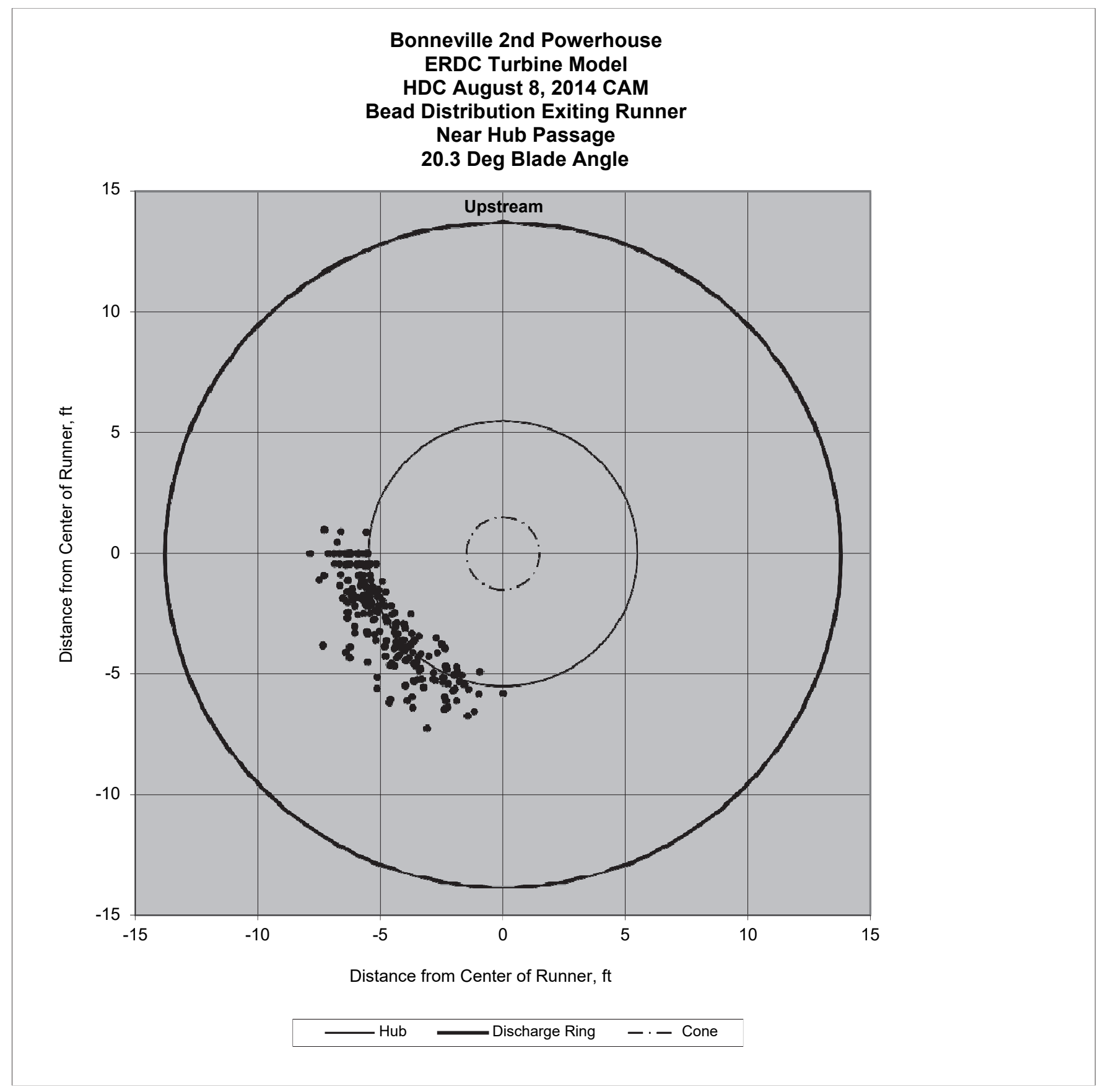




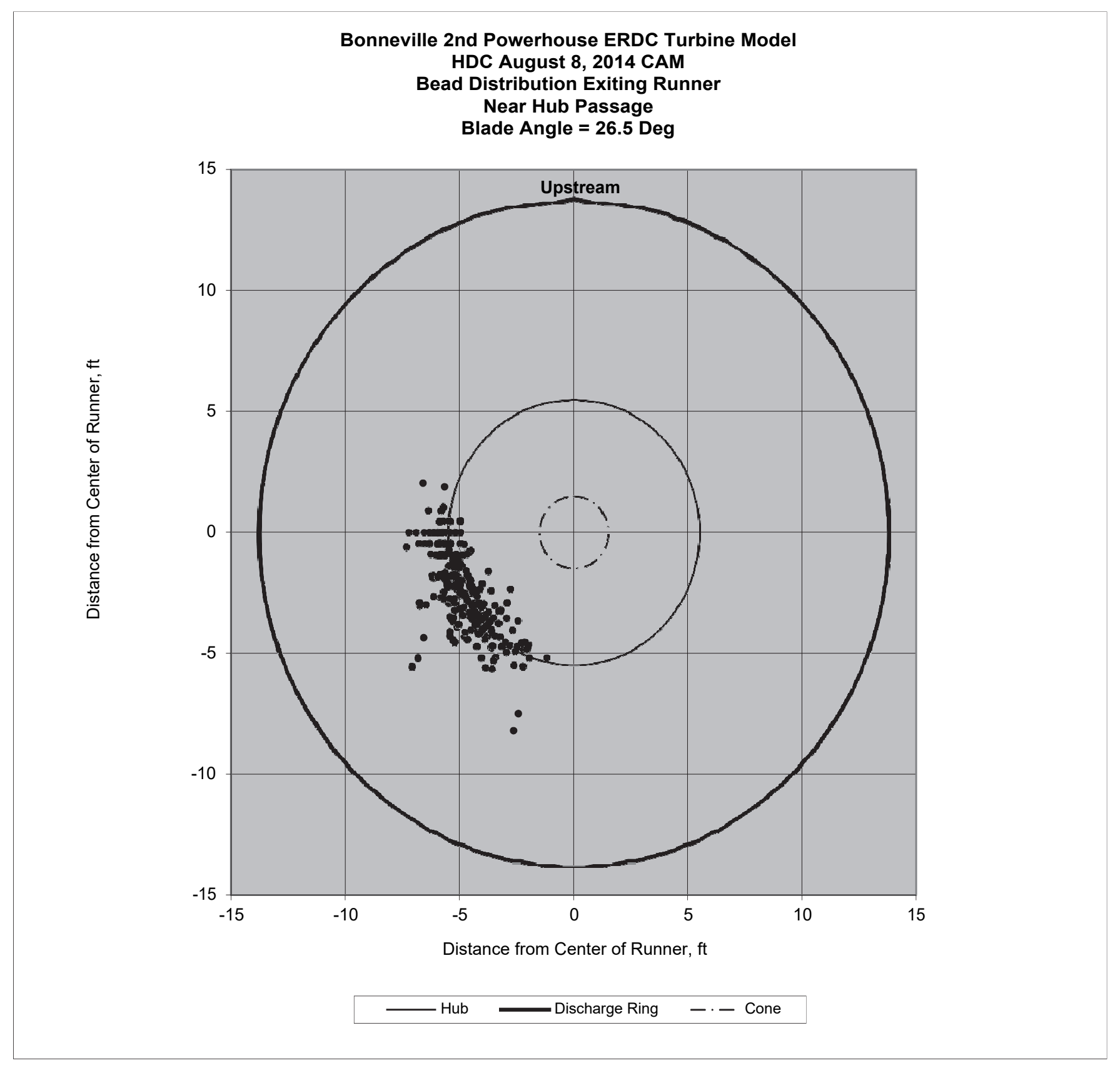


Bonneville 2nd Powherhouse

ERDC Turbine Model

Runner Contact Bead Passage Results

$55 \mathrm{ft} \mathrm{Head}$

Hub Region (Top Of Stay Vane Release)

\begin{tabular}{|c|c|c|c|c|c|c|c|c|c|c|}
\hline $\begin{array}{l}\text { Blade } \\
\text { Angle, } \\
\text { Deg }\end{array}$ & $\begin{array}{c}\text { Target } \\
\text { Discharge, } \\
\text { cfs }\end{array}$ & $\begin{array}{c}\text { Contact } \\
\text { score }\end{array}$ & $\begin{array}{c}\text { Contact } \\
\text { Stdev }\end{array}$ & $\begin{array}{c}\% \text { Severe } \\
\text { contact 1's } \\
\text { and 2's }\end{array}$ & $\begin{array}{c}\text { Standard } \\
\text { error }\end{array}$ & $\begin{array}{c}95 \% \\
\text { Confidence } \\
\text { interval }\end{array}$ & $\begin{array}{c}\% \text { Contact } \\
1 \text { 's , 2's } \\
\text { and 3's }\end{array}$ & $\begin{array}{c}\text { Standard } \\
\text { error } \%\end{array}$ & $\begin{array}{c}95 \% \\
\text { Confidence } \\
\text { interval }\end{array}$ & \# of beads \\
\hline 16.5 & 11280 & 5.38 & 1.25 & 6.0 & 0.93 & 1.83 & 9.8 & 1.17 & 2.29 & 650 \\
\hline 20.3 & 14925 & 5.62 & 0.98 & 3.7 & 0.74 & 1.45 & 5.5 & 0.90 & 1.76 & 650 \\
\hline 26.5 & 19115 & 5.65 & 0.92 & 3.2 & 0.69 & 1.36 & 4.6 & 0.82 & 1.61 & 650 \\
\hline
\end{tabular}

Bonneville 2nd Powherhouse ERDC Turbine Model

ERDC Turbine Model

Runner Change in Direction Bead Passage Results

$55 \mathrm{ft}$ Head

Hub Region (Top Of Stay Vane Release)

\begin{tabular}{|c|c|c|c|c|c|c|c|c|c|c|}
\hline $\begin{array}{l}\text { Blade } \\
\text { Angle, } \\
\text { Deg }\end{array}$ & $\begin{array}{c}\text { Target } \\
\text { Discharge, } \\
\text { cfs }\end{array}$ & $\begin{array}{c}\text { Direction } \\
\text { change } \\
\text { score }\end{array}$ & $\begin{array}{l}\text { Direction } \\
\text { Change } \\
\text { Stdev }\end{array}$ & $\begin{array}{c}\% \text { Severe } \\
\text { Direction } \\
\text { Change } \\
1 \text { 's }\end{array}$ & $\begin{array}{c}\text { Standard } \\
\text { error }\end{array}$ & $\begin{array}{c}95 \% \\
\text { Confidence } \\
\text { interval }\end{array}$ & $\begin{array}{c}\% \text { Severe } \\
\text { to } \\
\text { Moderate } \\
\text { Direction } \\
\text { Change } \\
1 \text { 's and 2's }\end{array}$ & $\begin{array}{l}\text { Standard } \\
\text { error } \%\end{array}$ & $\begin{array}{c}95 \% \\
\text { Confidence } \\
\text { interval }\end{array}$ & \# of beads \\
\hline 16.5 & 11280 & 3.24 & 0.86 & 4.8 & 0.84 & 1.64 & 18.5 & 1.52 & 2.98 & 650 \\
\hline 20.3 & 14925 & 3.40 & 0.76 & 2.5 & 0.61 & 1.19 & 12.0 & 1.27 & 2.50 & 650 \\
\hline 26.5 & 19115 & 3.37 & 0.74 & 2.0 & 0.55 & 1.08 & 11.4 & 1.25 & 2.44 & 650 \\
\hline
\end{tabular}

Bonneville 2nd Powherhouse ERDC Turbine Model

ERDC Turbine Model

Runner Bead Product Results

$55 \mathrm{ft} \mathrm{Head}$

Hub Region (Top Of Stay Vane Release)

\begin{tabular}{|c|c|c|c|c|c|}
\hline $\begin{array}{c}\text { Blade } \\
\text { Angle, } \\
\text { Deg }\end{array}$ & $\begin{array}{c}\text { Target } \\
\text { Discharge, } \\
\text { cfs }\end{array}$ & $\begin{array}{c}\text { Procduct } \\
\text { Score }\end{array}$ & $\begin{array}{c}\text { Procduct Std } \\
\text { Dev }\end{array}$ & $\begin{array}{c}\text { Hub Gap } \\
\text { Passage, } \\
\%\end{array}$ & \# beads \\
\hline 16.5 & 11280 & 18.33 & 6.77 & 5.1 & 650 \\
\hline 20.3 & 14925 & 19.68 & 4.56 & 2.0 & 650 \\
\hline 26.5 & 19115 & 19.52 & 5.60 & 0.5 & 650 \\
\hline
\end{tabular}




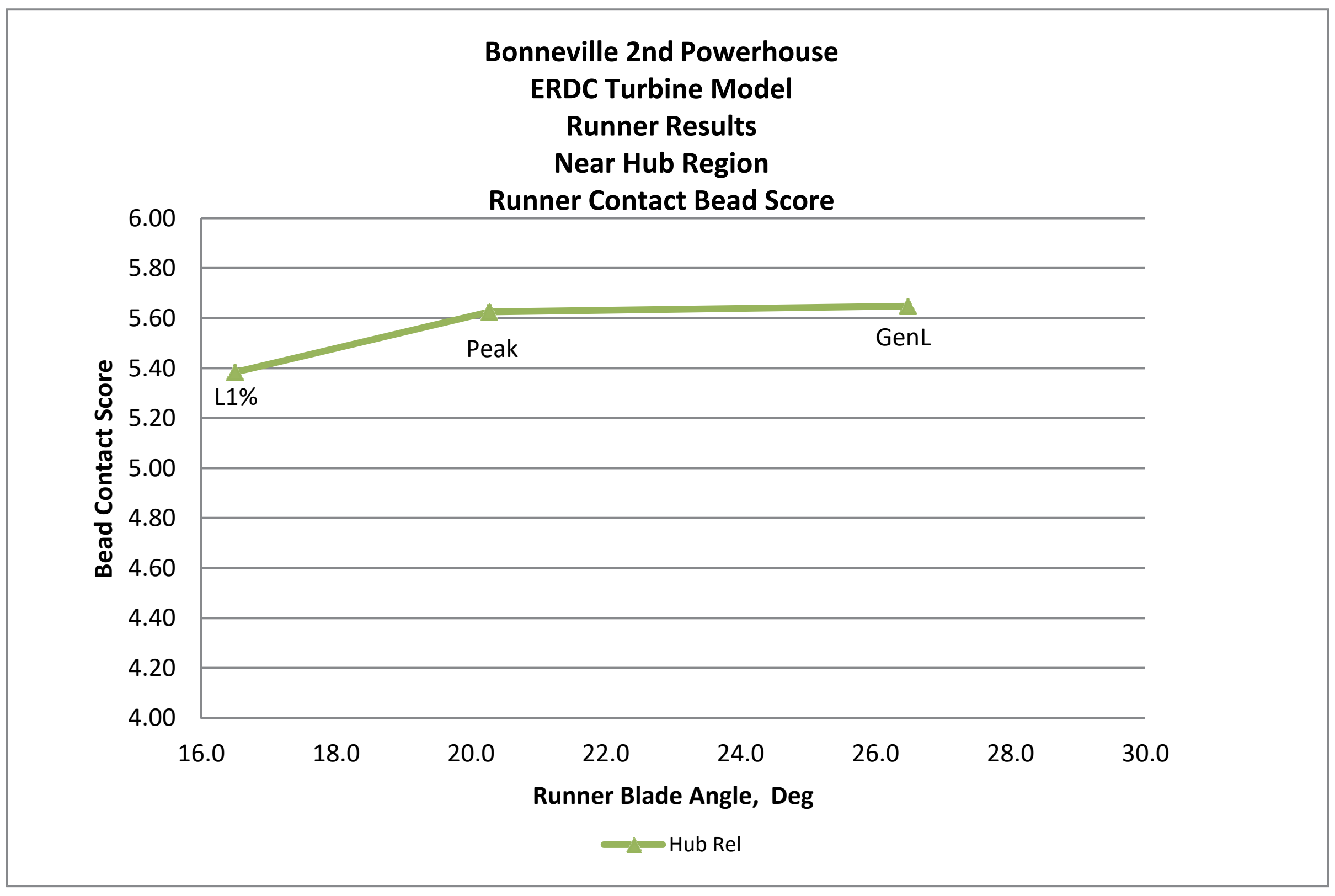




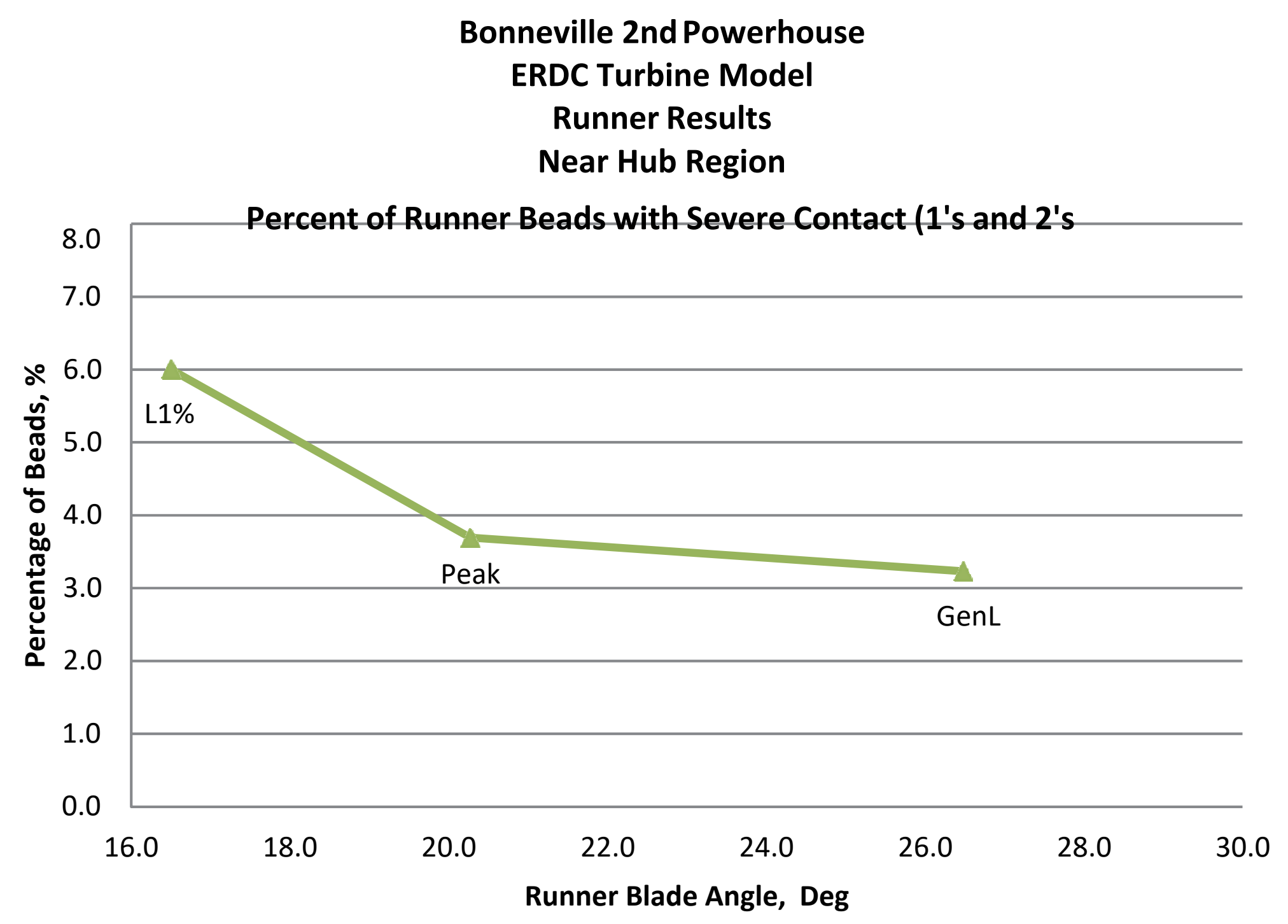




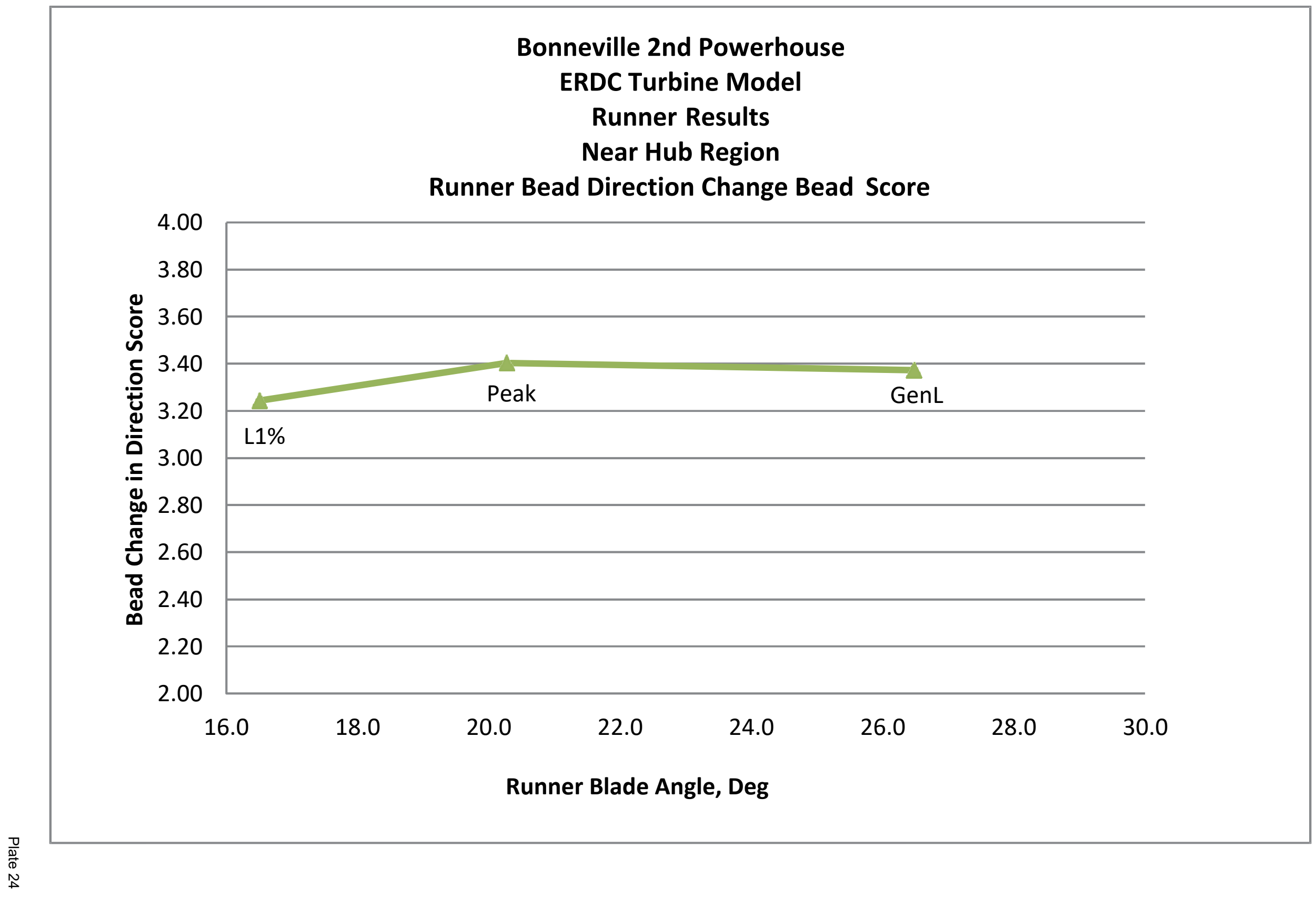




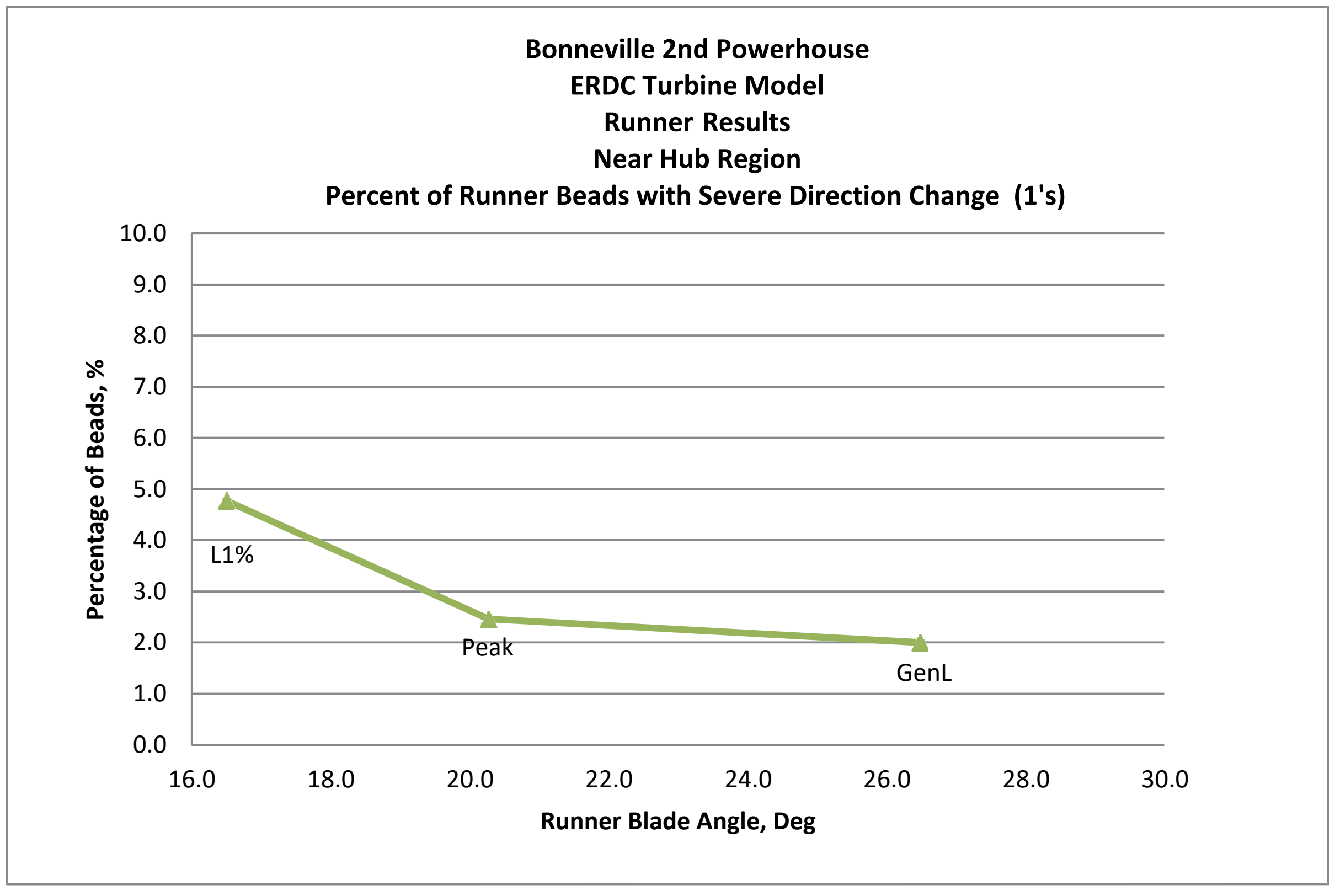




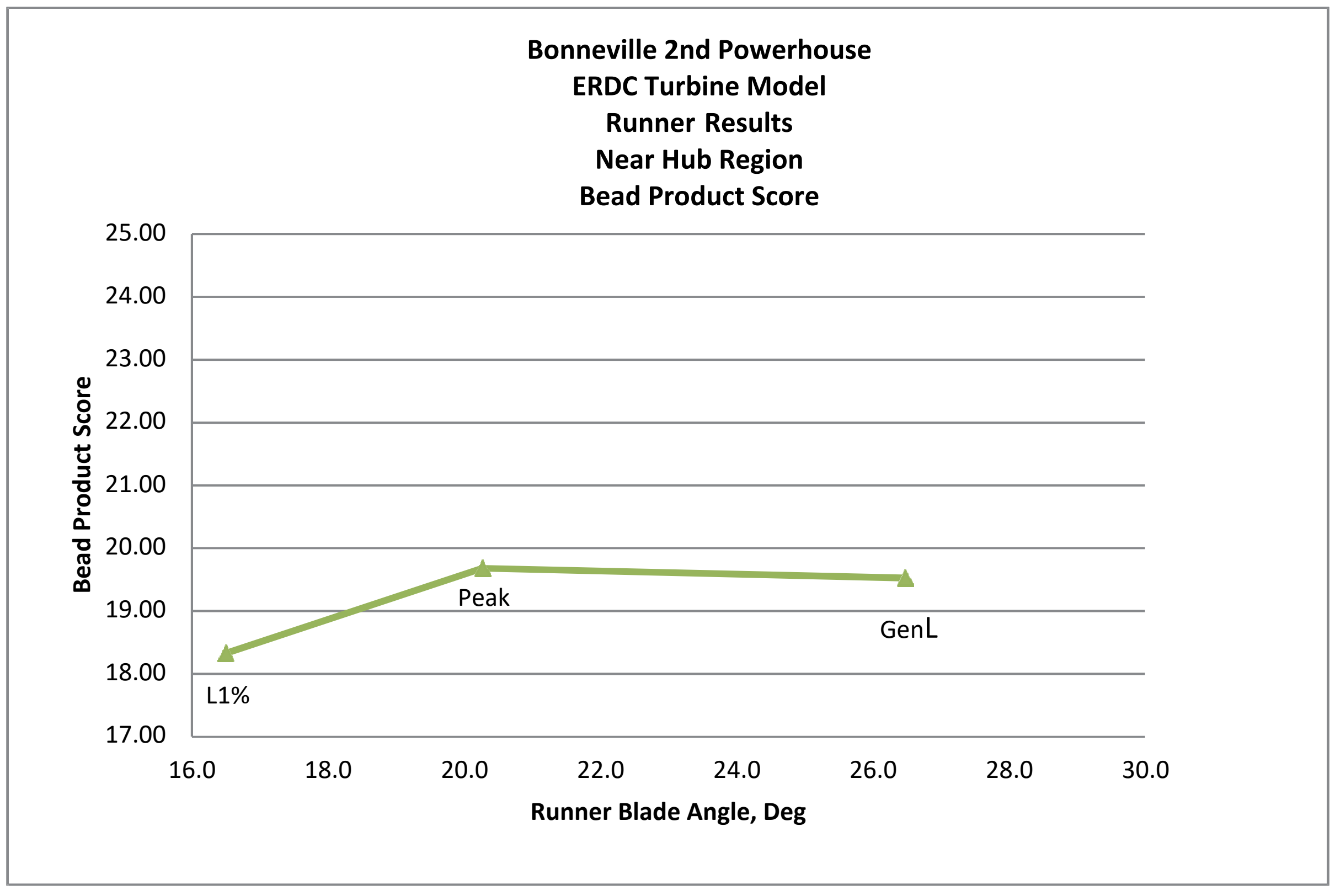




\section{Bonneville 2nd Powerhouse \\ ERDC Turbine Model \\ Runner Results \\ Percent Runner Hub Gap Passage}

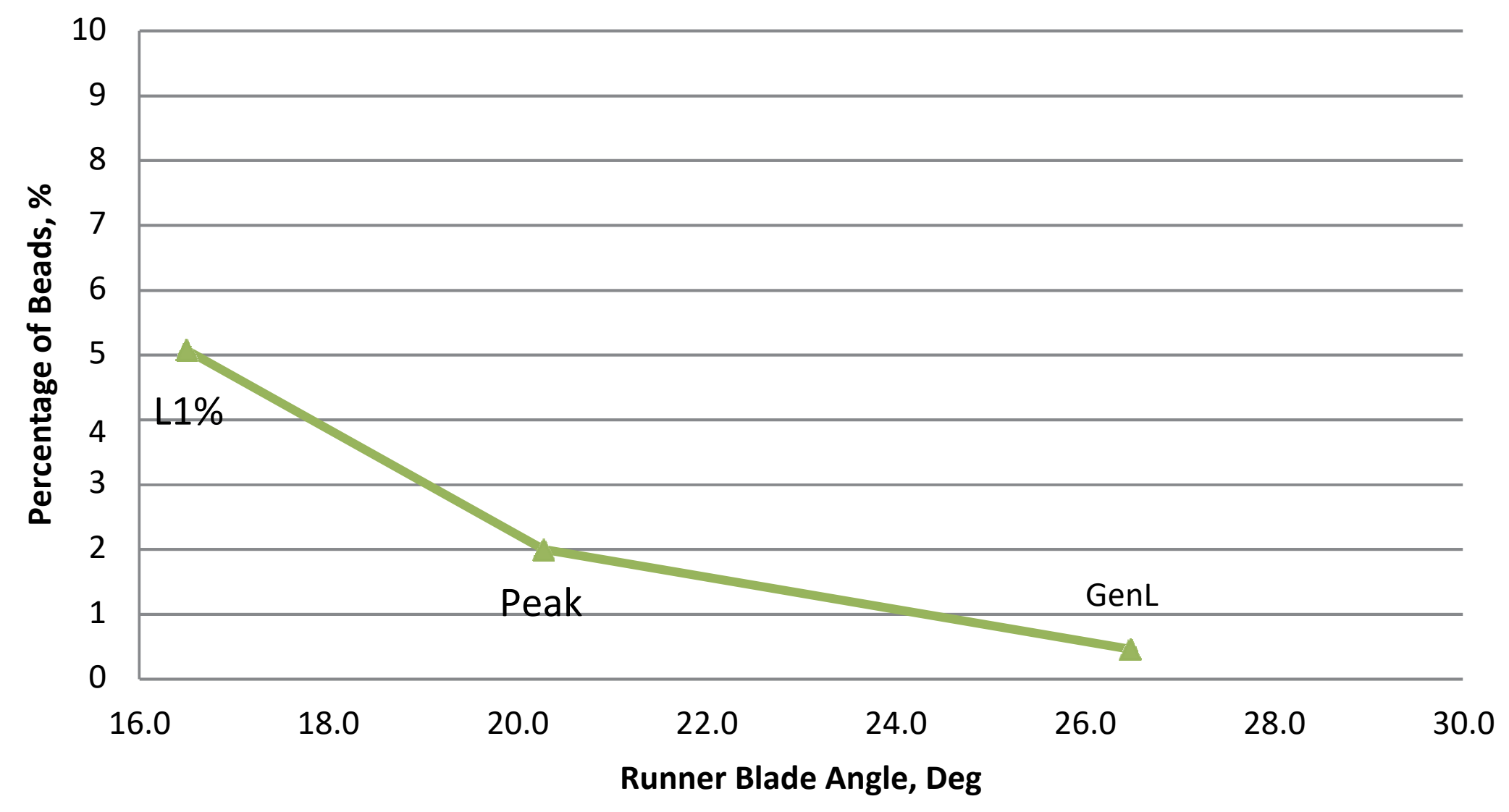




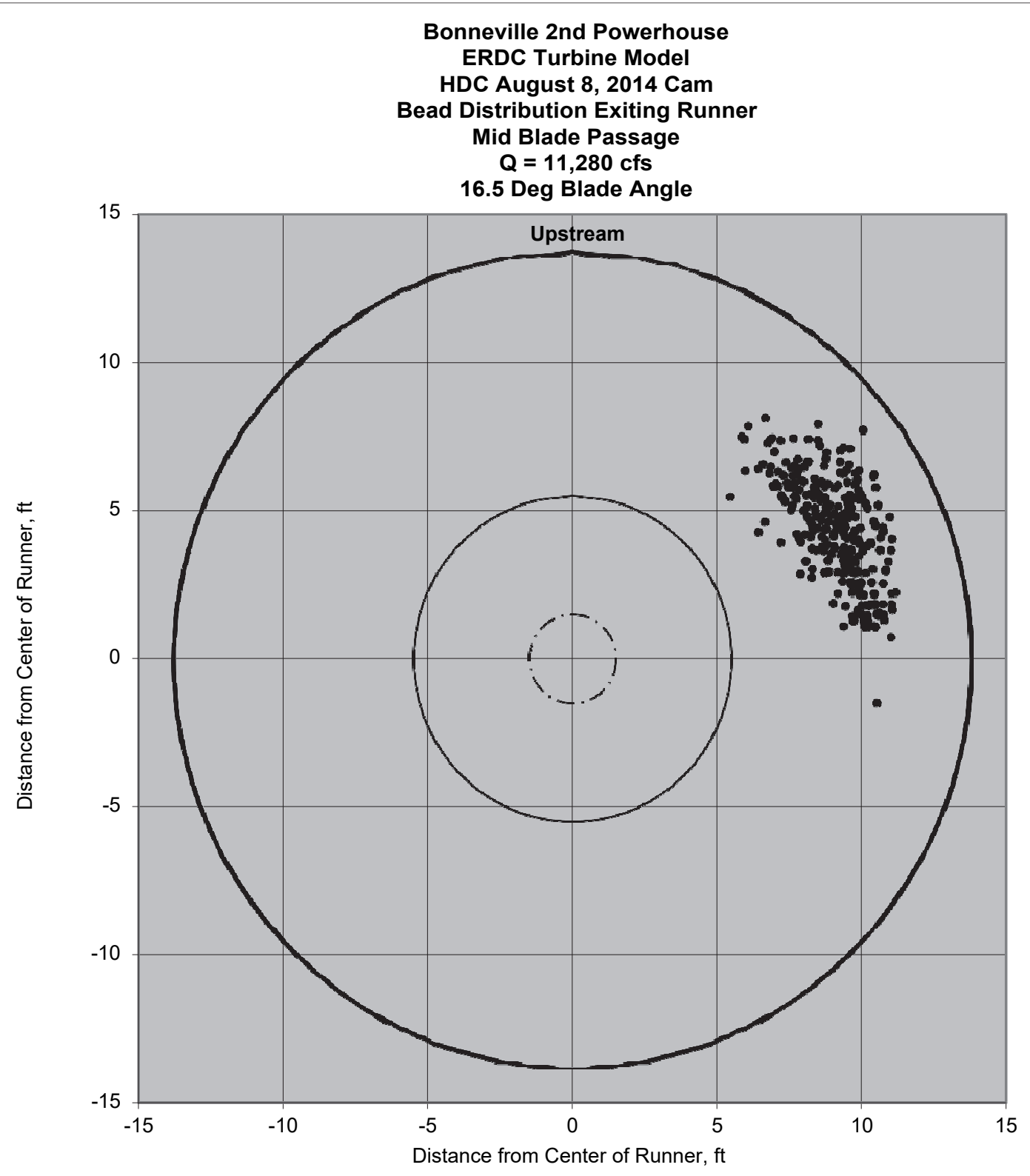

- Hub Discharge Ring $\quad-\cdot-$ Cone 


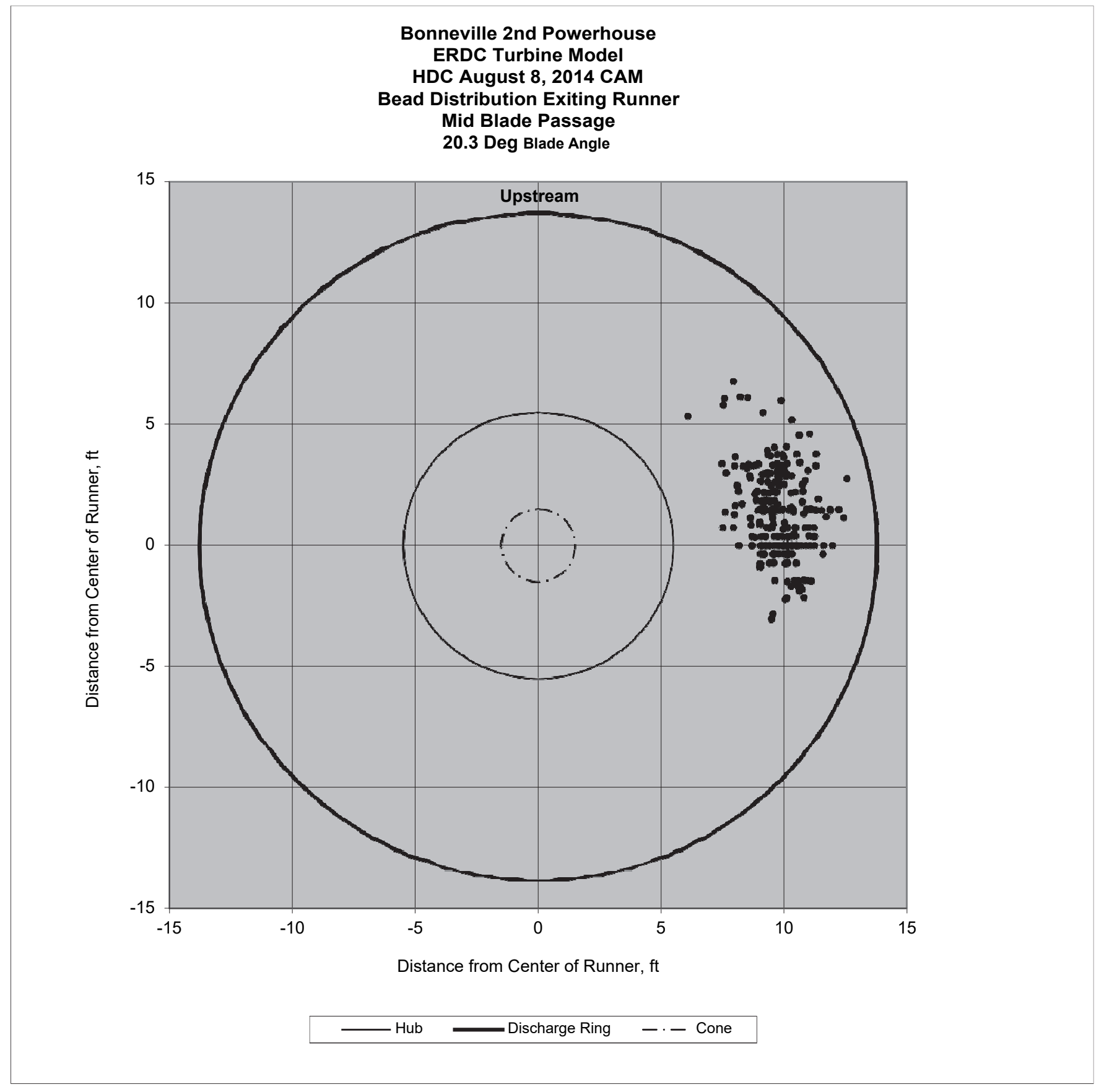




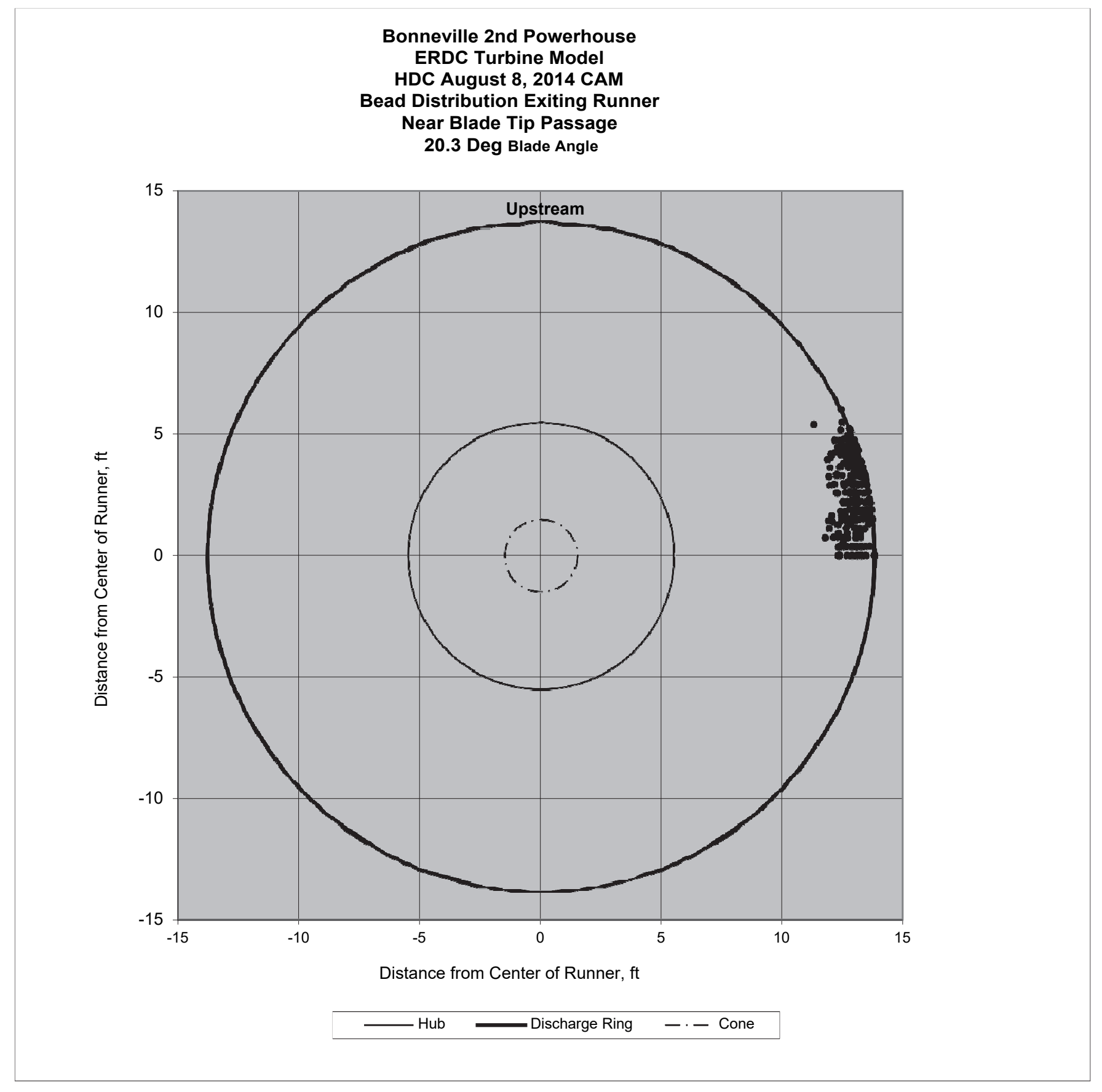


Bonneville 2nd Powherhouse

ERDC Turbine Model

Runner Contact Bead Passage Results

$55 \mathrm{ft} \mathrm{Head}$

Mid-blade Region (Middle Of Stay Vane Release)

\begin{tabular}{|c|c|c|c|c|c|c|c|c|c|c|}
\hline $\begin{array}{l}\text { Blade } \\
\text { Angle, } \\
\text { Deg }\end{array}$ & $\begin{array}{c}\text { Target } \\
\text { Discharge, } \\
\text { cfs }\end{array}$ & $\begin{array}{c}\text { Contact } \\
\text { score }\end{array}$ & $\begin{array}{c}\text { Contact } \\
\text { Stdev }\end{array}$ & $\begin{array}{c}\% \text { Severe } \\
\text { contact 1's } \\
\text { and 2's }\end{array}$ & $\begin{array}{c}\text { Standard } \\
\text { error }\end{array}$ & $\begin{array}{c}95 \% \\
\text { Confidence } \\
\text { interval }\end{array}$ & $\begin{array}{c}\% \text { Contact } \\
1 \text { 's , 2's } \\
\text { and 3's }\end{array}$ & $\begin{array}{l}\text { Standard } \\
\text { error } \%\end{array}$ & $\begin{array}{c}95 \% \\
\text { Confidence } \\
\text { interval }\end{array}$ & \# of beads \\
\hline 16.5 & 11280 & 5.79 & 0.82 & 3.1 & 0.82 & 1.60 & 3.6 & 0.87 & 1.71 & 450 \\
\hline 20.3 & 14925 & 5.87 & 0.54 & 1.1 & 0.49 & 0.97 & 1.3 & 0.54 & 1.06 & 450 \\
\hline 26.5 & 19115 & 5.88 & 0.57 & 1.1 & 0.49 & 0.97 & 1.6 & 0.58 & 1.14 & 450 \\
\hline
\end{tabular}

Bonneville 2nd Powherhouse ERDC Turbine Model

ERDC Turbine Model

Runner Change in Direction Bead Passage Results

$55 \mathrm{ft}$ Head

Mid-blade Region (Middle Of Stay Vane Release)

\begin{tabular}{|c|c|c|c|c|c|c|c|c|c|c|}
\hline $\begin{array}{l}\text { Blade } \\
\text { Angle, } \\
\text { Deg }\end{array}$ & $\begin{array}{c}\text { Target } \\
\text { Discharge, } \\
\text { cfs }\end{array}$ & $\begin{array}{l}\text { Direction } \\
\text { change } \\
\text { score }\end{array}$ & $\begin{array}{l}\text { Direction } \\
\text { Change } \\
\text { Stdev }\end{array}$ & $\begin{array}{l}\% \text { Severe } \\
\text { Direction } \\
\text { Change 1's }\end{array}$ & $\begin{array}{c}\text { Standard } \\
\text { error }\end{array}$ & $\begin{array}{c}95 \% \\
\text { Confidence } \\
\text { interval }\end{array}$ & $\begin{array}{c}\% \text { Severe } \\
\text { to } \\
\text { Moderate } \\
\text { Direction } \\
\text { Change } \\
1 \text { 's and 2's }\end{array}$ & $\begin{array}{c}\text { Standard } \\
\text { error } \%\end{array}$ & $\begin{array}{c}95 \% \\
\text { Confidence } \\
\text { interval }\end{array}$ & \# of beads \\
\hline 16.5 & 11280 & 3.55 & 0.69 & 3.1 & 0.82 & 1.60 & 5.3 & 1.06 & 2.08 & 450 \\
\hline 20.3 & 14925 & 3.65 & 0.57 & 0.7 & 0.38 & 0.75 & 3.6 & 0.87 & 1.71 & 450 \\
\hline 26.5 & 19115 & 3.70 & 0.56 & 0.8 & 0.41 & 0.81 & 1.7 & 0.61 & 1.19 & 450 \\
\hline
\end{tabular}

Bonneville 2nd Powherhouse ERDC Turbine Model

ERDC Turbine Model

Runner Bead Product Results

$55 \mathrm{ft} \mathrm{Head}$

Mid-blade Region (Middle Of Stay Vane Release)

\begin{tabular}{|c|c|c|c|c|}
\hline $\begin{array}{c}\text { Blade } \\
\text { Angle, } \\
\text { Deg }\end{array}$ & $\begin{array}{c}\text { Target } \\
\text { Discharge, } \\
\text { cfs }\end{array}$ & $\begin{array}{c}\text { Procduct } \\
\text { Score }\end{array}$ & $\begin{array}{c}\text { Procduct Std } \\
\text { Dev }\end{array}$ & \# beads \\
\hline 16.5 & 11280 & 20.95 & 4.99 & 450 \\
\hline 20.3 & 14925 & 21.65 & 4.00 & 450 \\
\hline 26.5 & 19115 & 21.95 & 3.98 & 450 \\
\hline
\end{tabular}




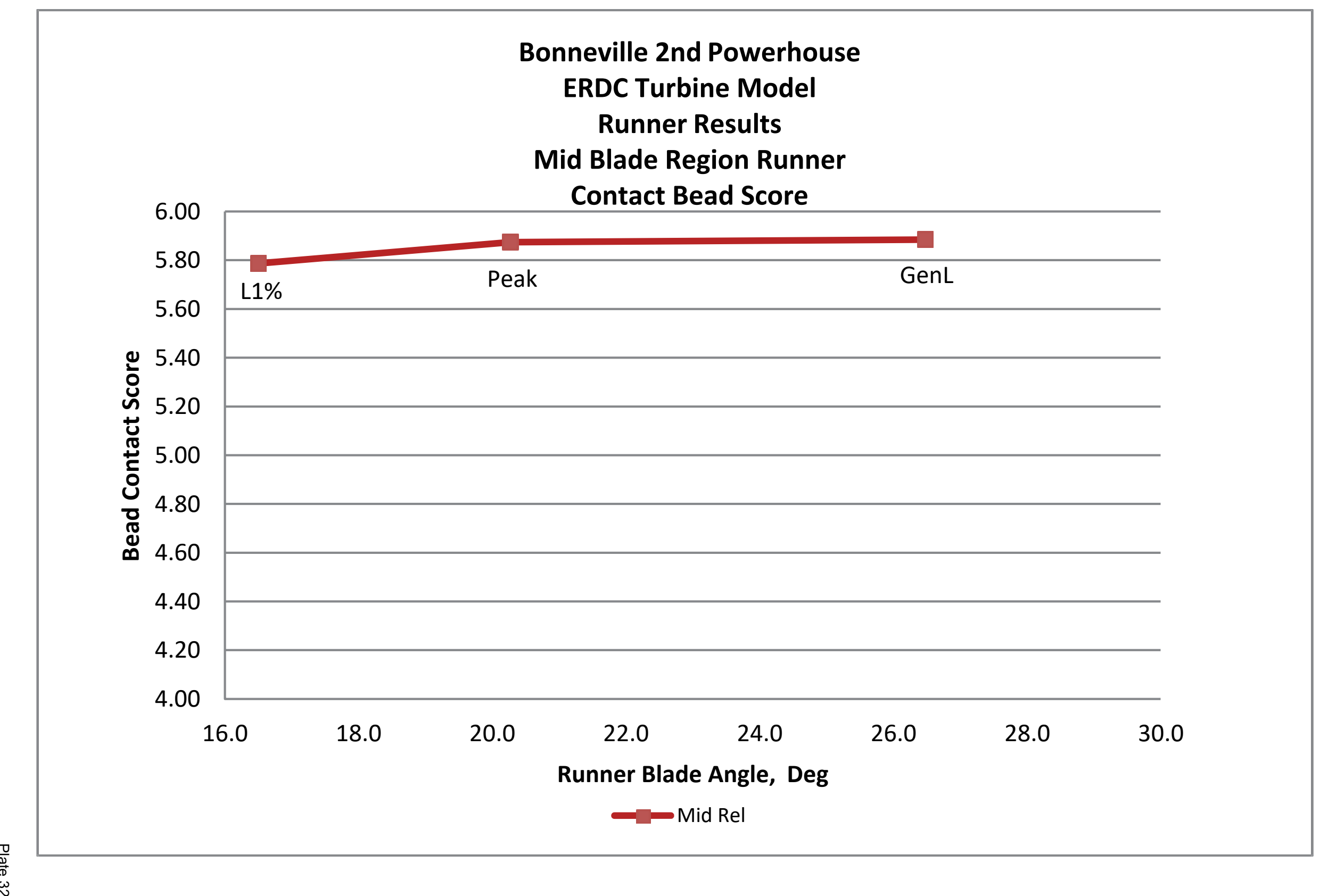




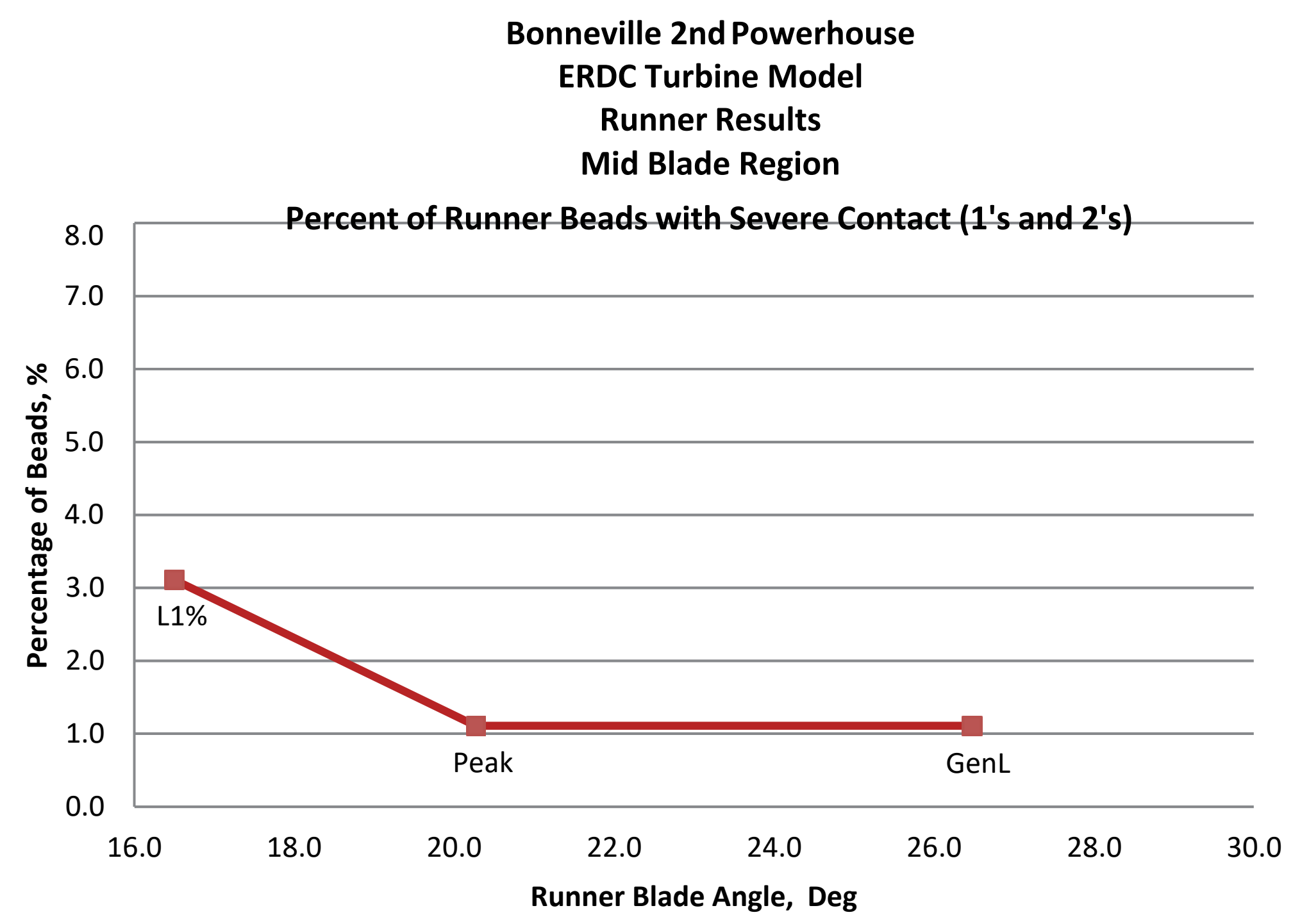




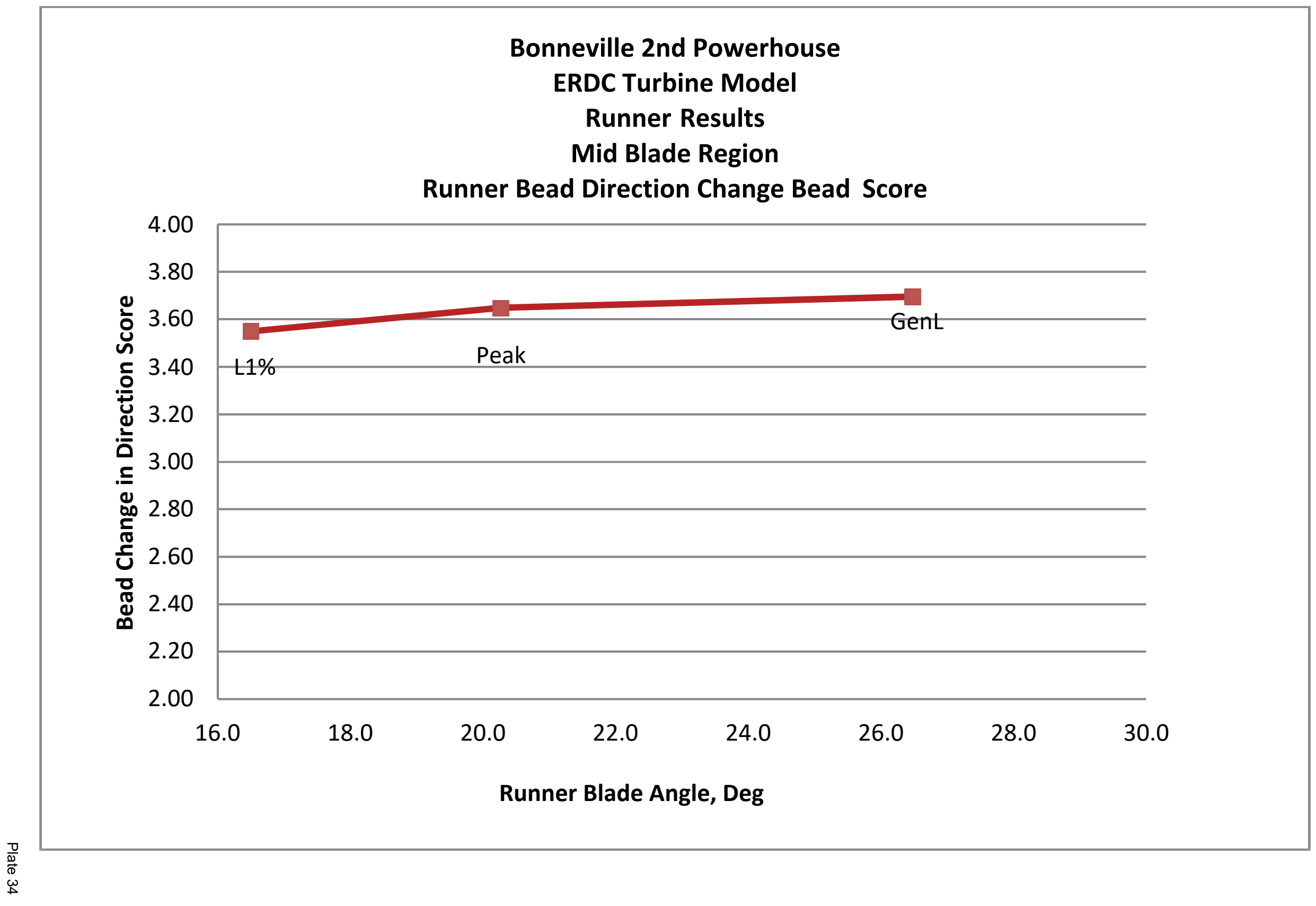




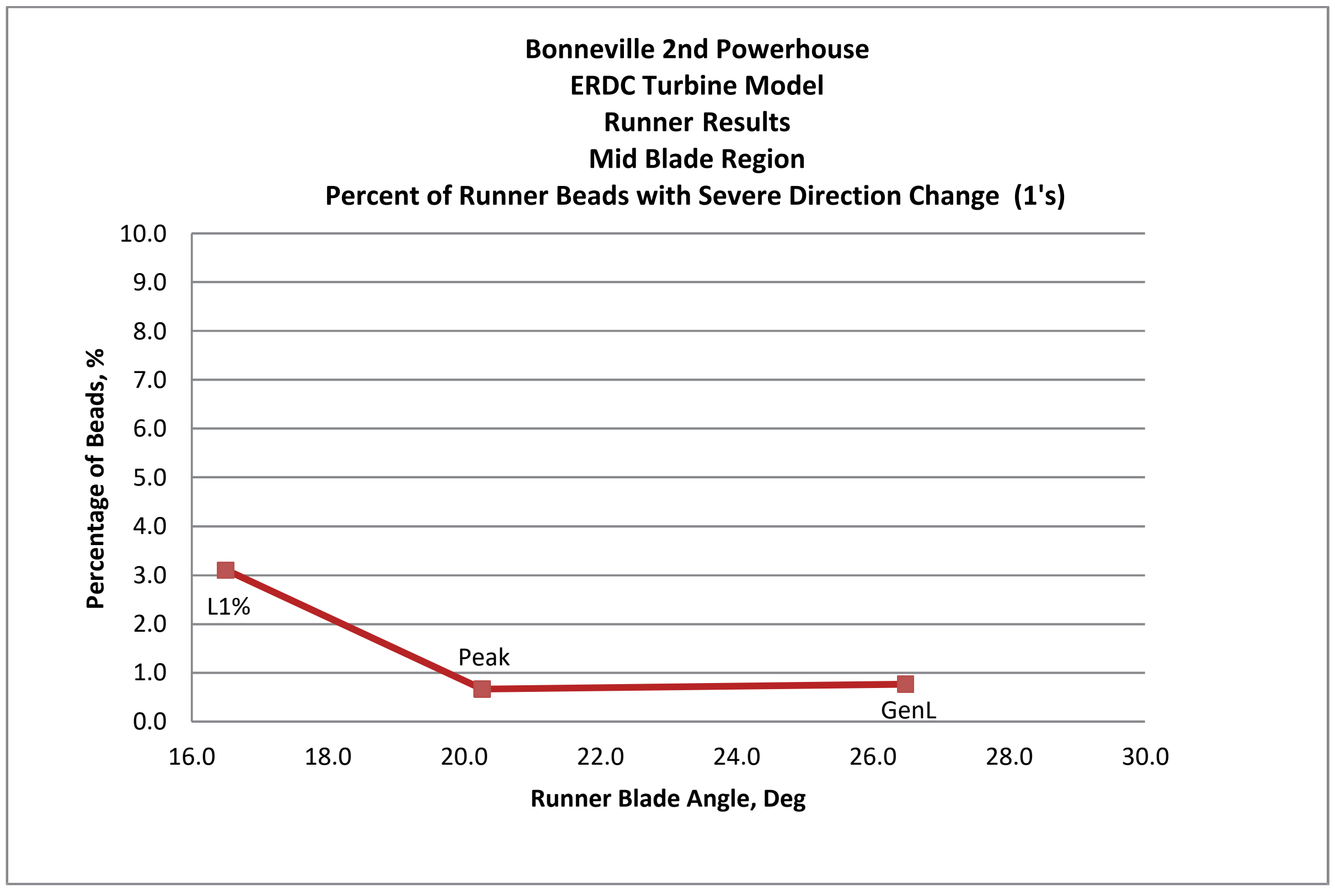




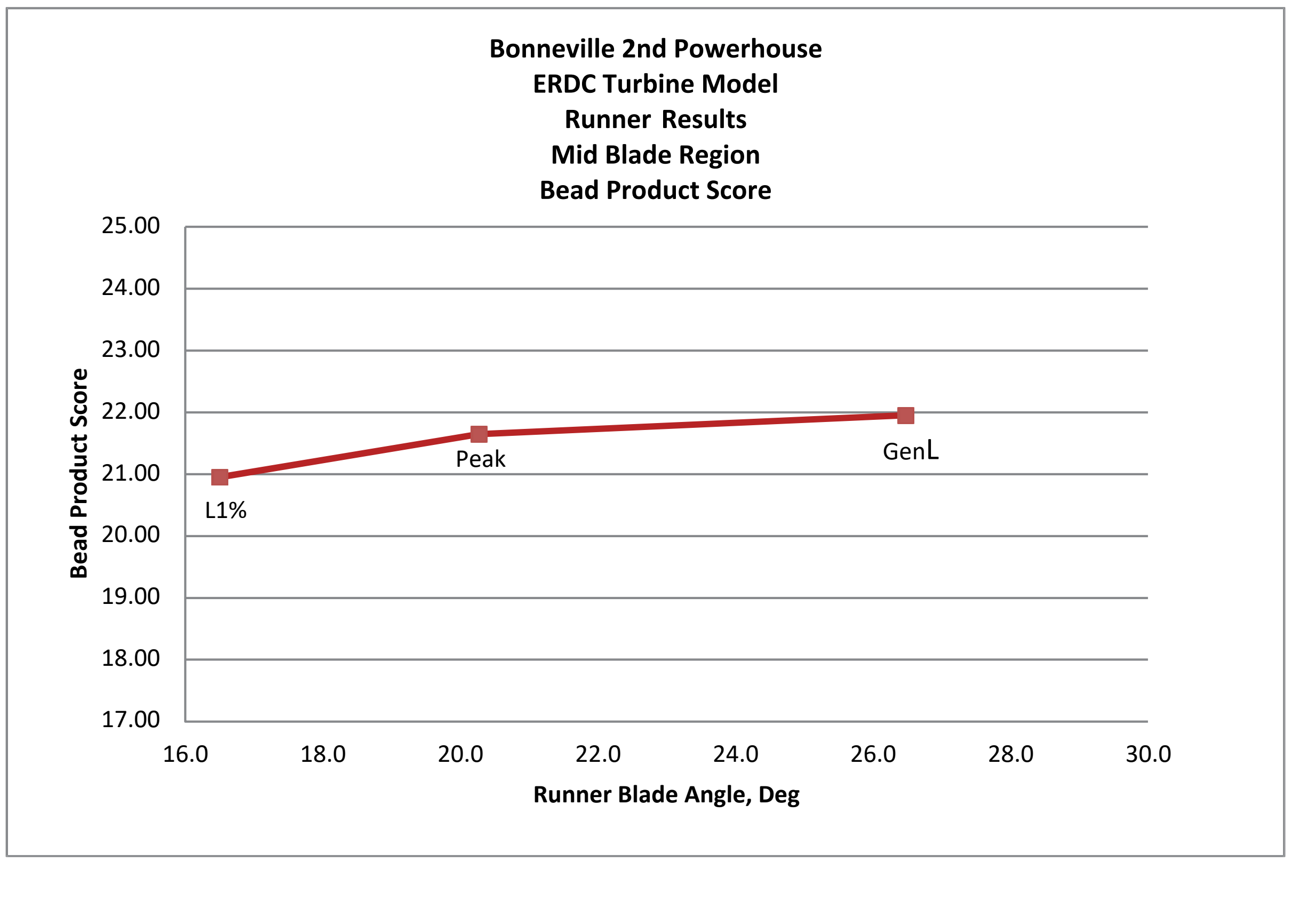




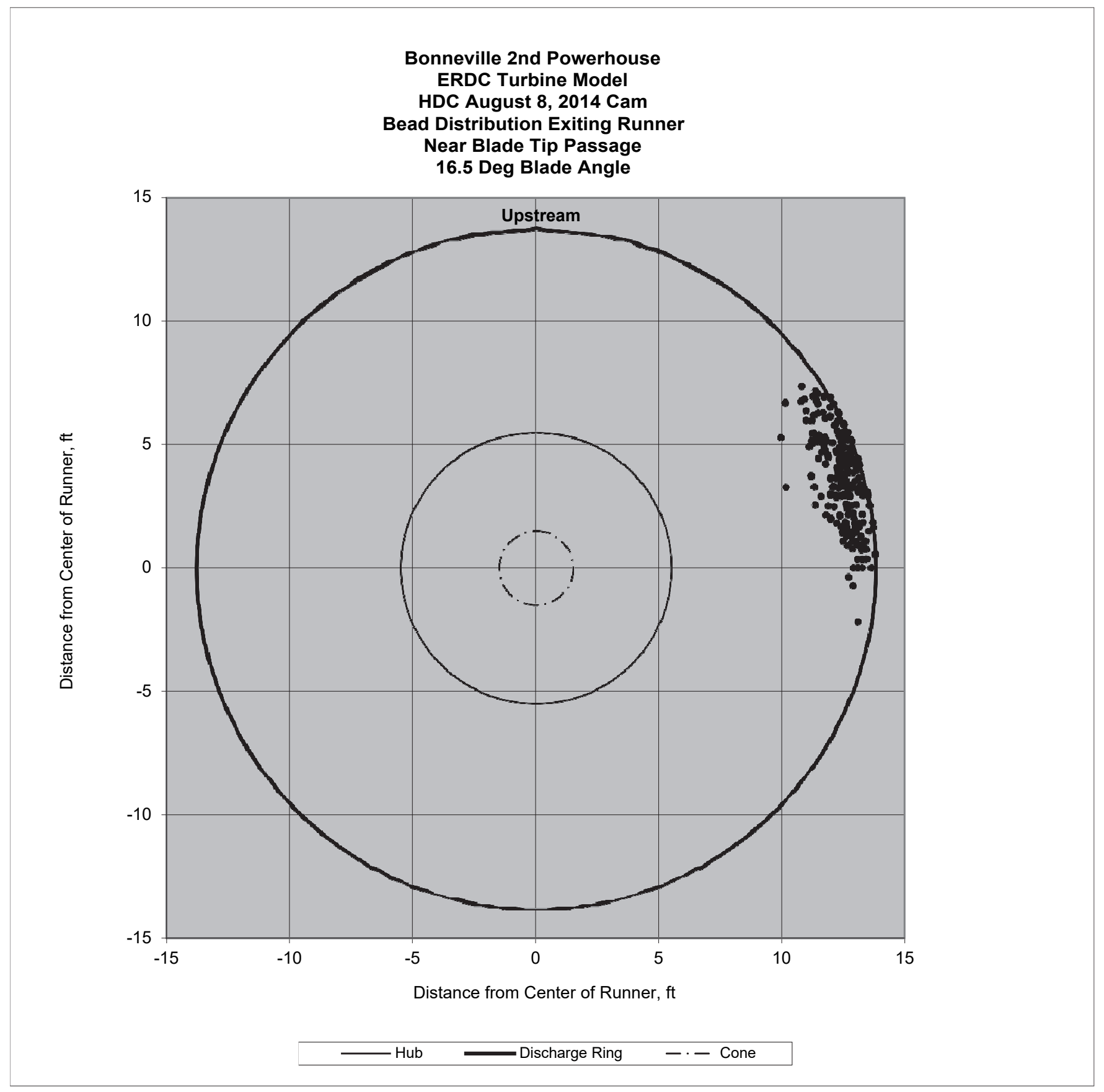




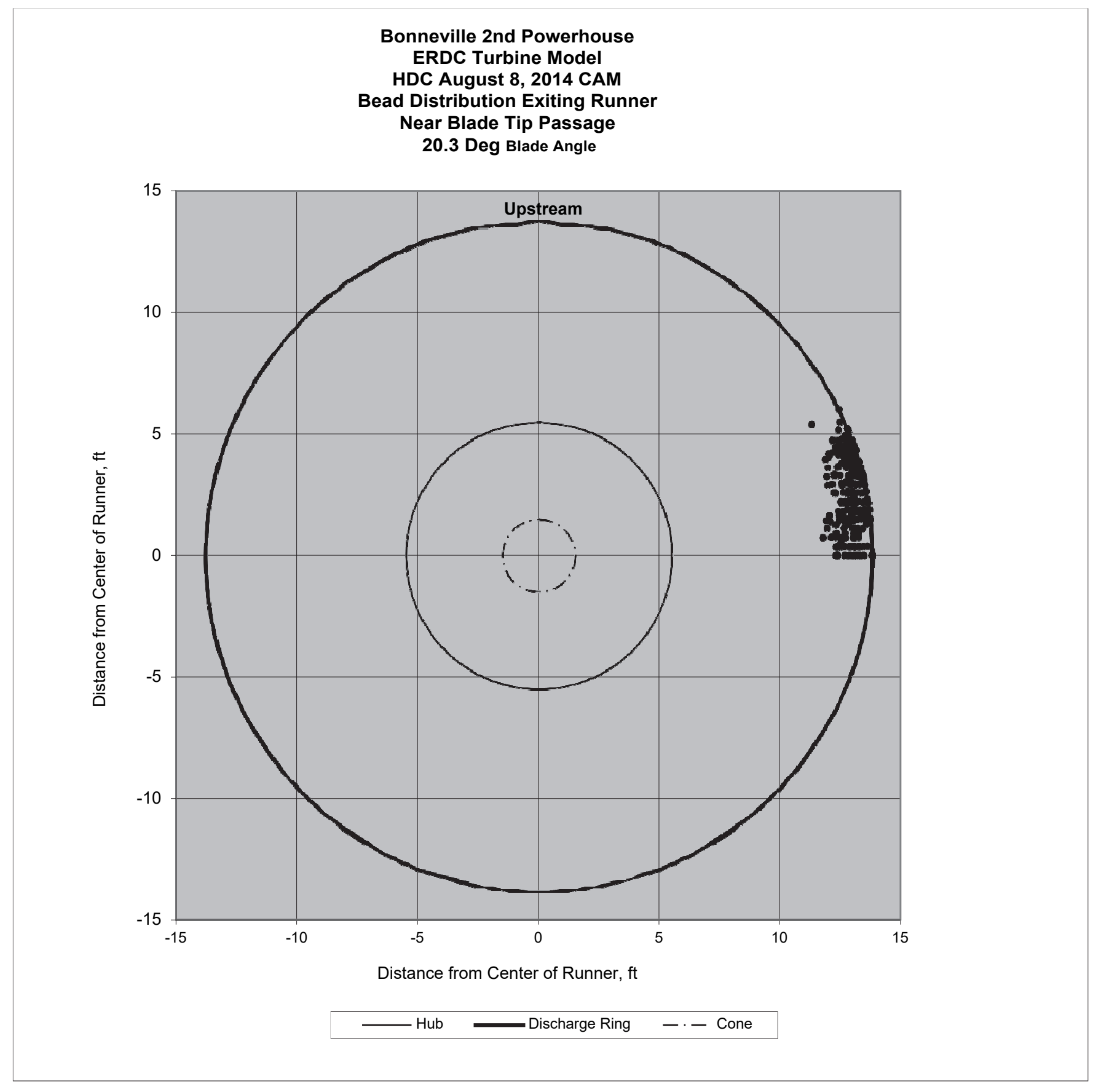




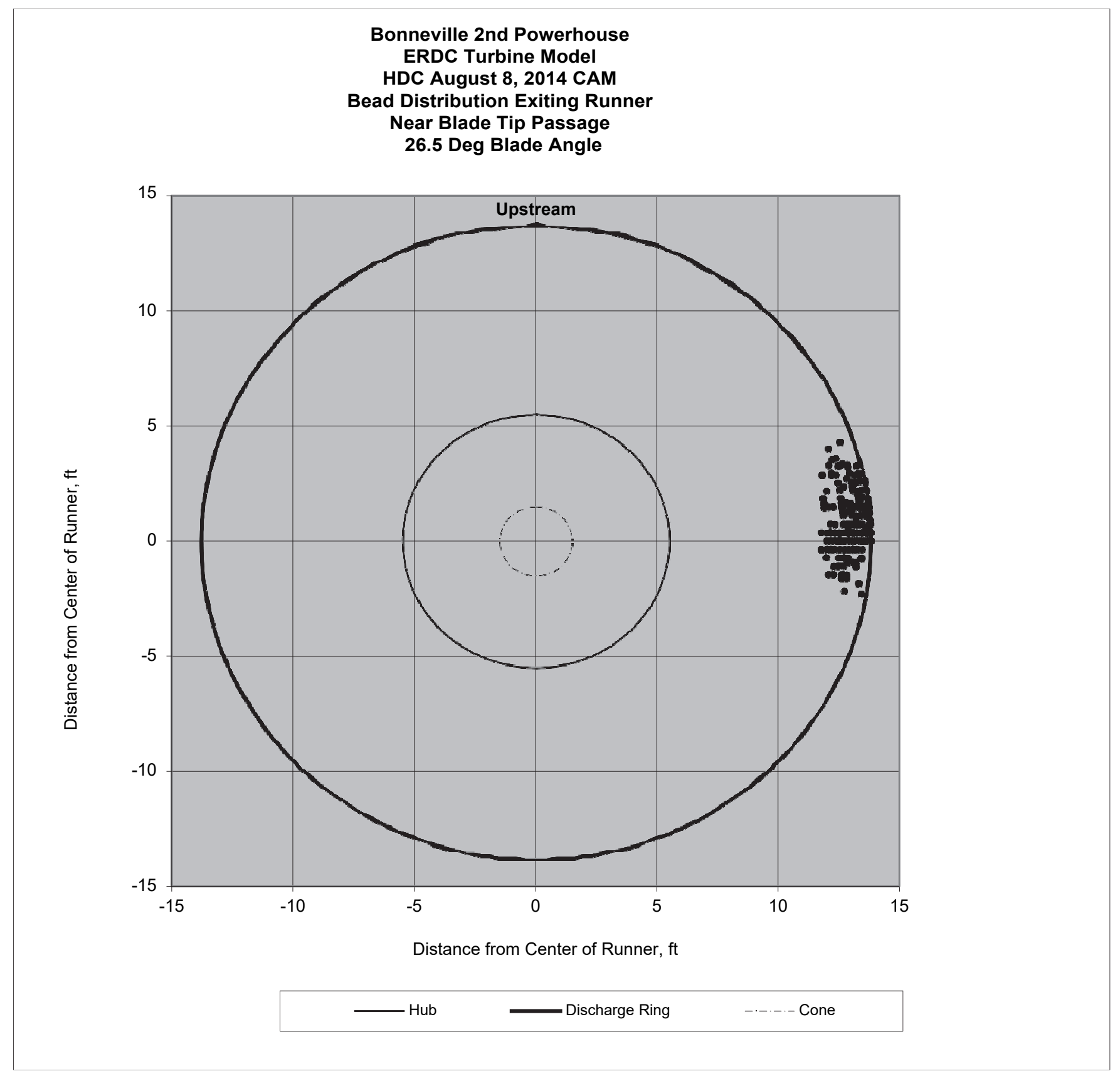


Bonneville 2nd Powherhouse

ERDC Turbine Model

Runner Contact Bead Passage Results 55

$55 \mathrm{ft} \mathrm{Head}$

Tip Region (Bottom Of Stay Vane Release)

\begin{tabular}{|c|c|c|c|c|c|c|c|c|c|c|}
\hline $\begin{array}{l}\text { Blade } \\
\text { Angle, } \\
\text { Deg }\end{array}$ & $\begin{array}{c}\text { Target } \\
\text { Discharge, cfs }\end{array}$ & $\begin{array}{c}\text { Contact } \\
\text { score }\end{array}$ & $\begin{array}{c}\text { Contact } \\
\text { Stdev }\end{array}$ & $\begin{array}{c}\% \text { Severe } \\
\text { contact 1's } \\
\text { and 2's }\end{array}$ & $\begin{array}{c}\text { Standard } \\
\text { error }\end{array}$ & $\begin{array}{c}95 \% \\
\text { Confidence } \\
\text { interval }\end{array}$ & $\begin{array}{c}\% \text { Contact } \\
\text { 1's , 2's } \\
\text { and 3's }\end{array}$ & $\begin{array}{c}\text { Standard } \\
\text { error } \%\end{array}$ & $\begin{array}{c}95 \% \\
\text { Confidence } \\
\text { interval }\end{array}$ & \# of beads \\
\hline 16.5 & 11280 & 5.53 & 1.05 & 4.3 & 0.80 & 1.56 & 6.5 & 0.96 & 1.89 & 650 \\
\hline 20.3 & 14925 & 5.67 & 0.91 & 2.6 & 0.63 & 1.23 & 4.3 & 0.80 & 1.56 & 650 \\
\hline 26.5 & 19115 & 5.65 & 0.89 & 2.8 & 0.64 & 1.26 & 4.2 & 0.78 & 1.53 & 650 \\
\hline
\end{tabular}

Bonneville 2nd Powherhouse ERDC Turbine Model

ERDC Turbine Model

Runner Change in Direction Bead Passage Results

$55 \mathrm{ft} \mathrm{Head}$

Tip Region (Bottom Of Stay Vane Release)

\begin{tabular}{|c|c|c|c|c|c|c|c|c|c|c|}
\hline $\begin{array}{l}\text { Blade } \\
\text { Angle, } \\
\text { Deg }\end{array}$ & $\begin{array}{c}\text { Target } \\
\text { Discharge, cfs }\end{array}$ & $\begin{array}{c}\text { Direction } \\
\text { change } \\
\text { score }\end{array}$ & $\begin{array}{l}\text { Direction } \\
\text { Change } \\
\text { Stdev }\end{array}$ & $\begin{array}{l}\text { \% Severe } \\
\text { Direction } \\
\text { Change 1's }\end{array}$ & $\begin{array}{c}\text { Standard } \\
\text { error }\end{array}$ & $\begin{array}{c}95 \% \\
\text { Confidence } \\
\text { interval }\end{array}$ & $\begin{array}{c}\% \text { Severe } \\
\text { to } \\
\text { Moderate } \\
\text { Direction } \\
\text { Change } \\
1 \text { 's and 2's }\end{array}$ & $\begin{array}{c}\text { Standard } \\
\text { error } \%\end{array}$ & $\begin{array}{c}95 \% \\
\text { Confidence } \\
\text { interval }\end{array}$ & \# of beads \\
\hline 16.5 & 11280 & 3.06 & 0.95 & 9.2 & 1.14 & 2.23 & 23.2 & 1.66 & 3.25 & 650 \\
\hline 20.3 & 14925 & 3.07 & 0.85 & 7.1 & 1.01 & 1.97 & 18.8 & 1.53 & 3.00 & 650 \\
\hline 26.5 & 19115 & 3.06 & 0.85 & 6.5 & 0.96 & 1.89 & 20.5 & 1.58 & 3.10 & 650 \\
\hline
\end{tabular}

Bonneville 2nd Powherhouse ERDC Turbine Model

ERDC Turbine Model

Runner Bead Product Results

$55 \mathrm{ft} \mathrm{Head}$

Tip Region (Bottom Of Stay Vane Release)

\begin{tabular}{|c|c|c|c|c|}
\hline $\begin{array}{c}\text { Blade } \\
\text { Angle, } \\
\text { Deg }\end{array}$ & $\begin{array}{c}\text { Target } \\
\text { Discharge, } \\
\text { cfs }\end{array}$ & $\begin{array}{c}\text { Procduct } \\
\text { Score }\end{array}$ & $\begin{array}{c}\text { Procduct Std } \\
\text { Dev }\end{array}$ & \# beads \\
\hline 16.5 & 11280 & 17.62 & 6.67 & 650 \\
\hline 20.3 & 14925 & 17.88 & 5.93 & 650 \\
\hline 26.5 & 19115 & 17.75 & 5.91 & 650 \\
\hline
\end{tabular}




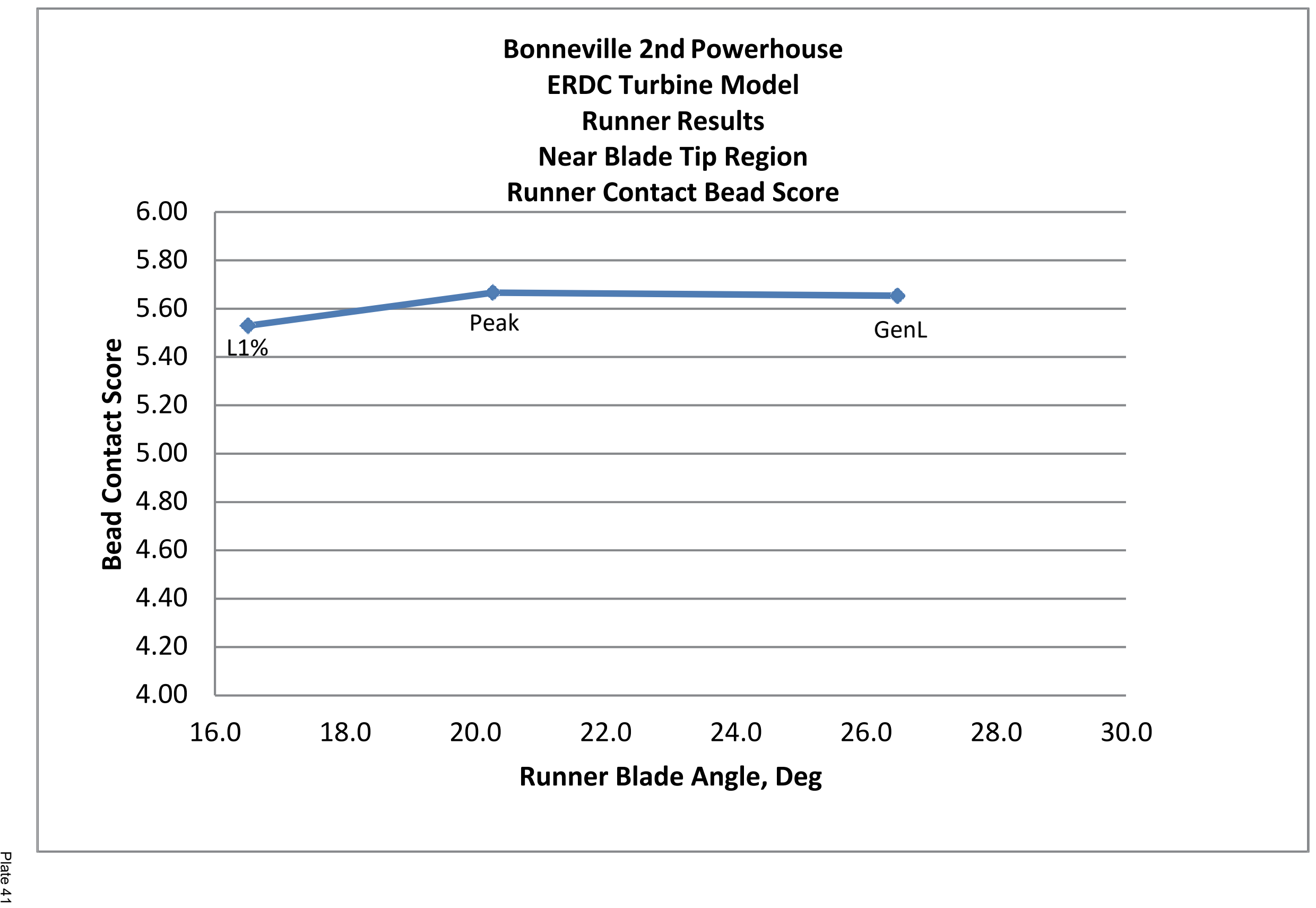




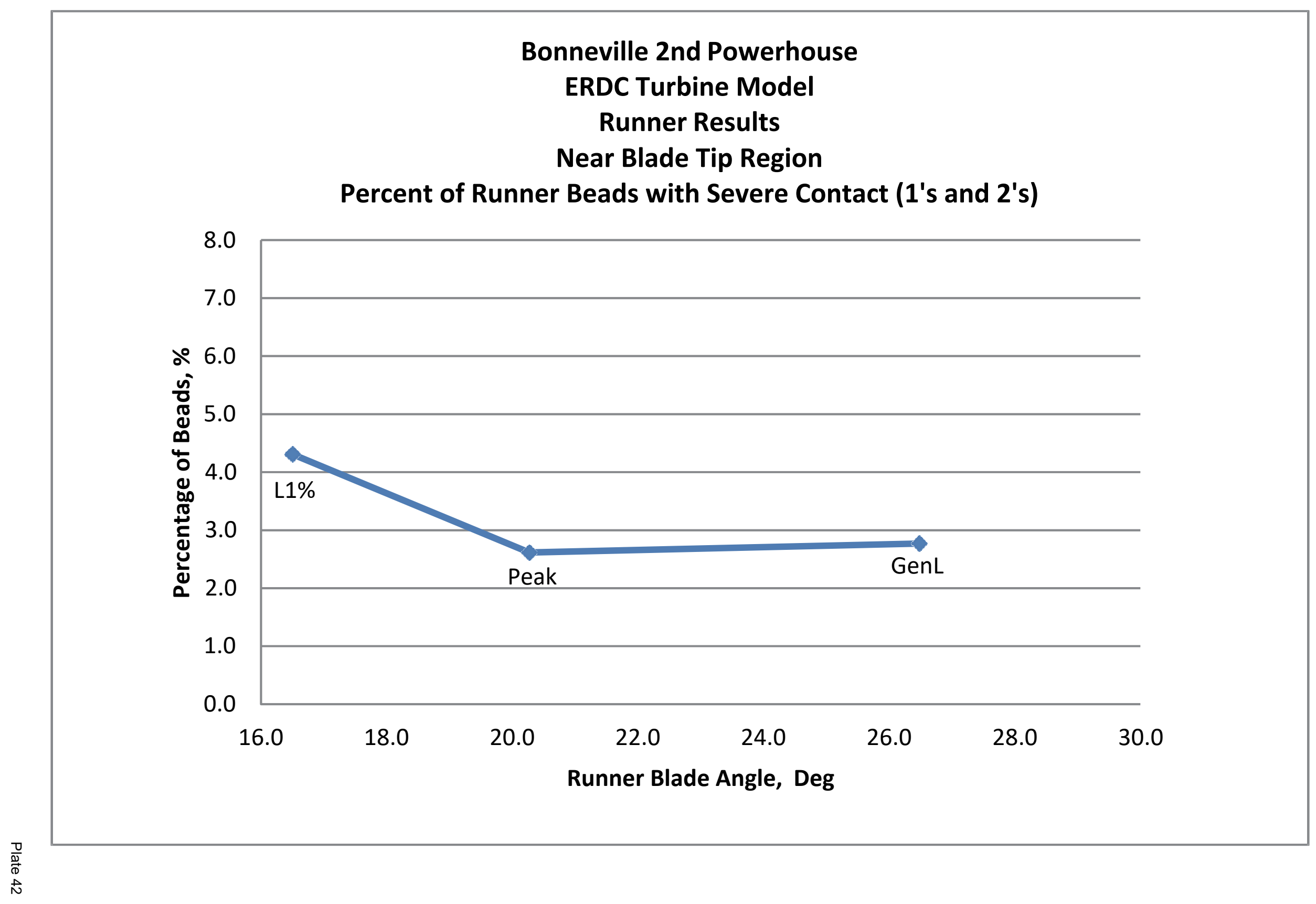




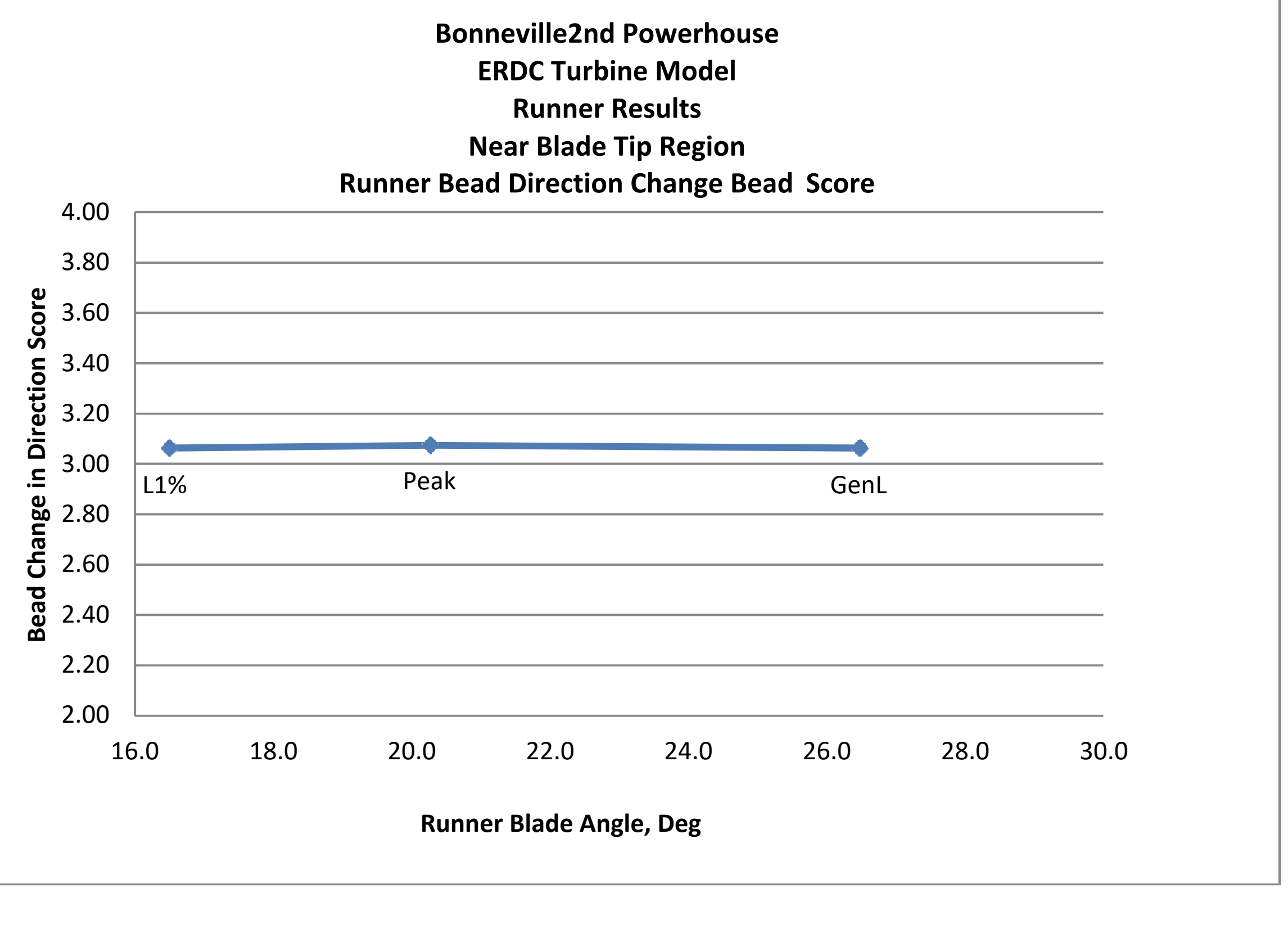




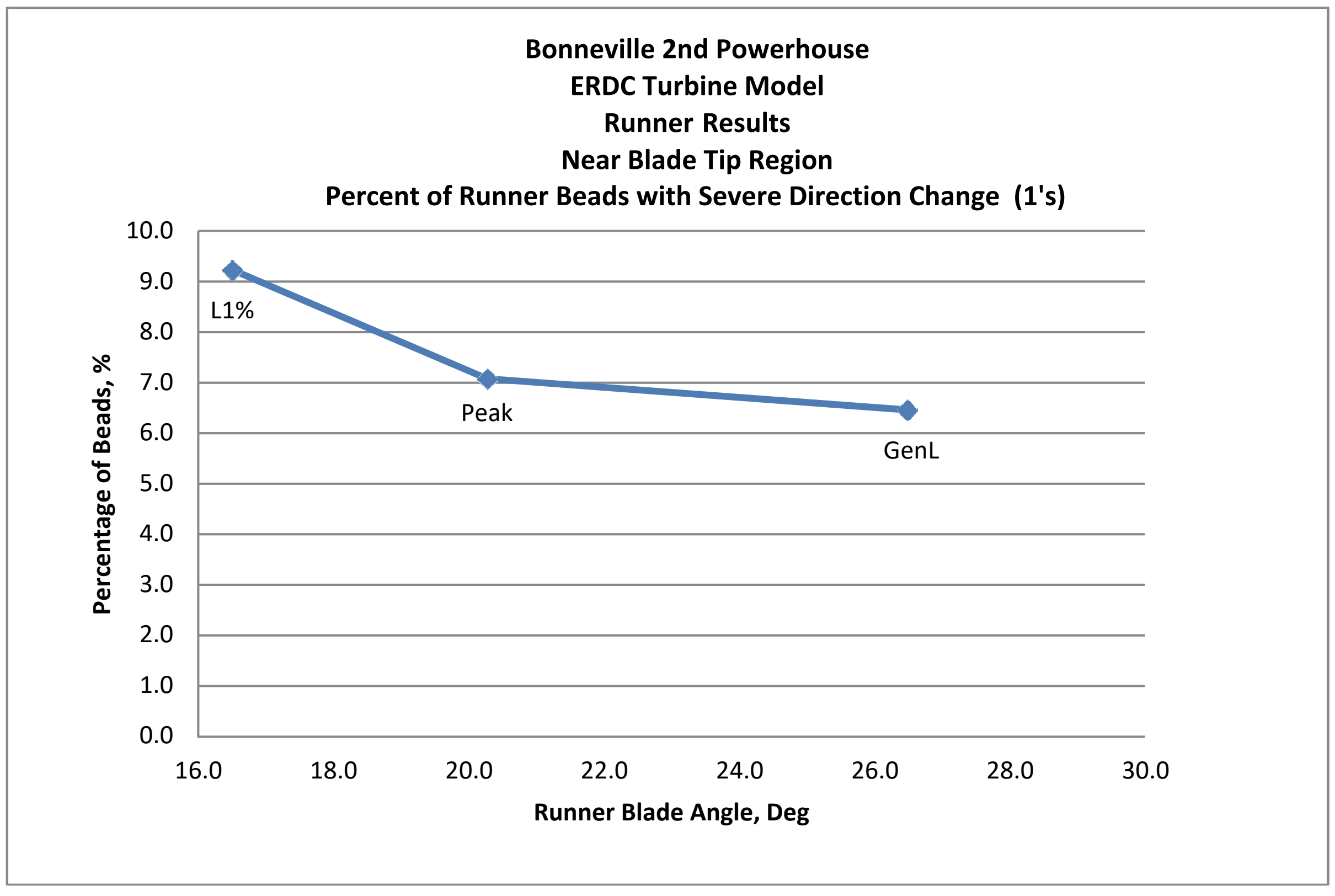




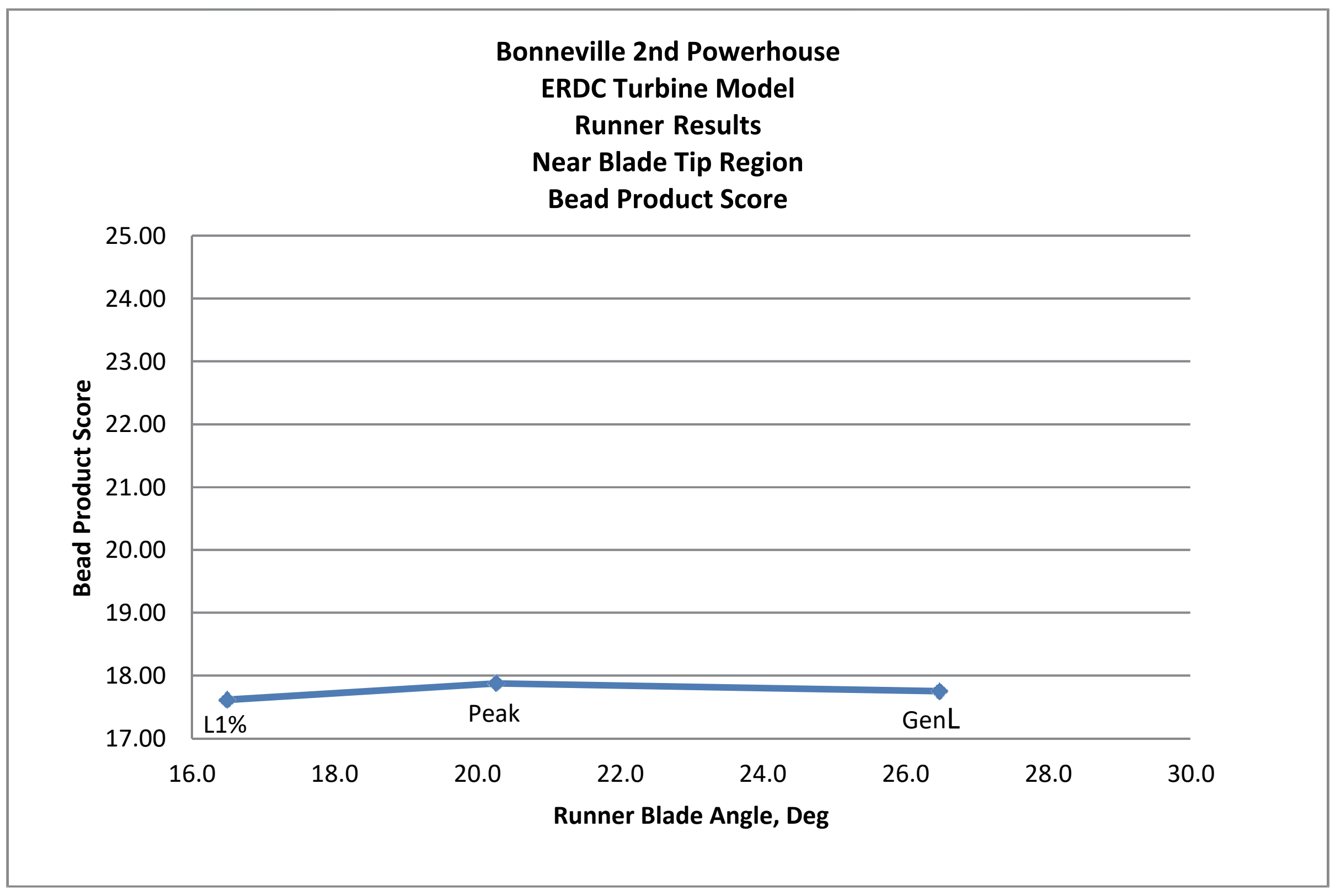


Bonneville 2nd Powherhouse

ERDC Turbine Model

Runner Contact Bead Passage Results

$55 \mathrm{ft} \mathrm{Head}$

All Regions Combined

\begin{tabular}{|c|c|c|c|c|c|c|c|c|c|c|}
\hline $\begin{array}{l}\text { Blade } \\
\text { Angle, } \\
\text { Deg }\end{array}$ & $\begin{array}{c}\text { Target } \\
\text { Discharge, cfs }\end{array}$ & $\begin{array}{c}\text { Contact } \\
\text { score }\end{array}$ & $\begin{array}{c}\text { Contact } \\
\text { Stdev }\end{array}$ & $\begin{array}{c}\% \text { Severe } \\
\text { contact 1's } \\
\text { and 2's }\end{array}$ & $\begin{array}{c}\text { Standard } \\
\text { error }\end{array}$ & $\begin{array}{c}95 \% \\
\text { Confidence } \\
\text { interval }\end{array}$ & $\begin{array}{c}\% \text { Contact } \\
\text { 1's , 2's } \\
\text { and 3's }\end{array}$ & $\begin{array}{c}\text { Standard } \\
\text { error } \%\end{array}$ & $\begin{array}{c}95 \% \\
\text { Confidence } \\
\text { interval }\end{array}$ & \# of beads \\
\hline 16.5 & 11280 & 5.57 & 1.04 & 4.5 & 0.49 & 0.97 & 6.6 & 0.59 & 1.17 & 1750 \\
\hline 20.3 & 14925 & 5.72 & 0.81 & 2.5 & 0.37 & 0.73 & 3.7 & 0.45 & 0.89 & 1750 \\
\hline 26.5 & 19115 & 5.73 & 0.79 & 2.4 & 0.36 & 0.71 & 3.4 & 0.44 & 0.85 & 1750 \\
\hline
\end{tabular}

Bonneville 2nd Powherhouse ERDC Turbine Model

ERDC Turbine Model

Runner Change in Direction Bead Passage Results

$55 \mathrm{ft}$ Head

All Regions Combined

\begin{tabular}{|c|c|c|c|c|c|c|c|c|c|c|}
\hline $\begin{array}{l}\text { Blade } \\
\text { Angle, } \\
\text { Deg }\end{array}$ & $\begin{array}{c}\text { Target } \\
\text { Discharge, cfs }\end{array}$ & $\begin{array}{c}\text { Direction } \\
\text { change } \\
\text { score }\end{array}$ & $\begin{array}{l}\text { Direction } \\
\text { Change } \\
\text { Stdev }\end{array}$ & $\begin{array}{l}\text { \% Severe } \\
\text { Direction } \\
\text { Change 1's }\end{array}$ & $\begin{array}{c}\text { Standard } \\
\text { error }\end{array}$ & $\begin{array}{c}95 \% \\
\text { Confidence } \\
\text { interval }\end{array}$ & $\begin{array}{c}\% \text { Severe } \\
\text { to } \\
\text { Moderate } \\
\text { Direction } \\
\text { Change } \\
1 \text { 's and 2's }\end{array}$ & $\begin{array}{c}\text { Standard } \\
\text { error } \%\end{array}$ & $\begin{array}{c}95 \% \\
\text { Confidence } \\
\text { interval }\end{array}$ & \# of beads \\
\hline 16.5 & 11280 & 3.29 & 0.83 & 5.7 & 0.55 & 1.09 & 15.7 & 0.87 & 1.70 & 1750 \\
\hline 20.3 & 14925 & 3.38 & 0.73 & 3.4 & 0.43 & 0.85 & 11.4 & 0.76 & 1.49 & 1750 \\
\hline 26.5 & 19115 & 3.38 & 0.72 & 3.1 & 0.41 & 0.81 & 11.2 & 0.75 & 1.48 & 1750 \\
\hline
\end{tabular}

Bonneville 2nd Powherhouse ERDC Turbine Model

ERDC Turbine Model

Runner Bead Product Results

$55 \mathrm{ft} \mathrm{Head}$

All Regions Combined

\begin{tabular}{|c|c|c|c|c|}
\hline $\begin{array}{c}\text { Blade } \\
\text { Angle, } \\
\text { Deg }\end{array}$ & $\begin{array}{c}\text { Target } \\
\text { Discharge, } \\
\text { cfs }\end{array}$ & $\begin{array}{c}\text { Procduct } \\
\text { Score }\end{array}$ & $\begin{array}{c}\text { Procduct Std } \\
\text { Dev }\end{array}$ & \# beads \\
\hline 16.5 & 11280 & 18.97 & 6.15 & 1750 \\
\hline 20.3 & 14925 & 19.74 & 4.83 & 1750 \\
\hline 26.5 & 19115 & 19.74 & 5.16 & 1750 \\
\hline
\end{tabular}




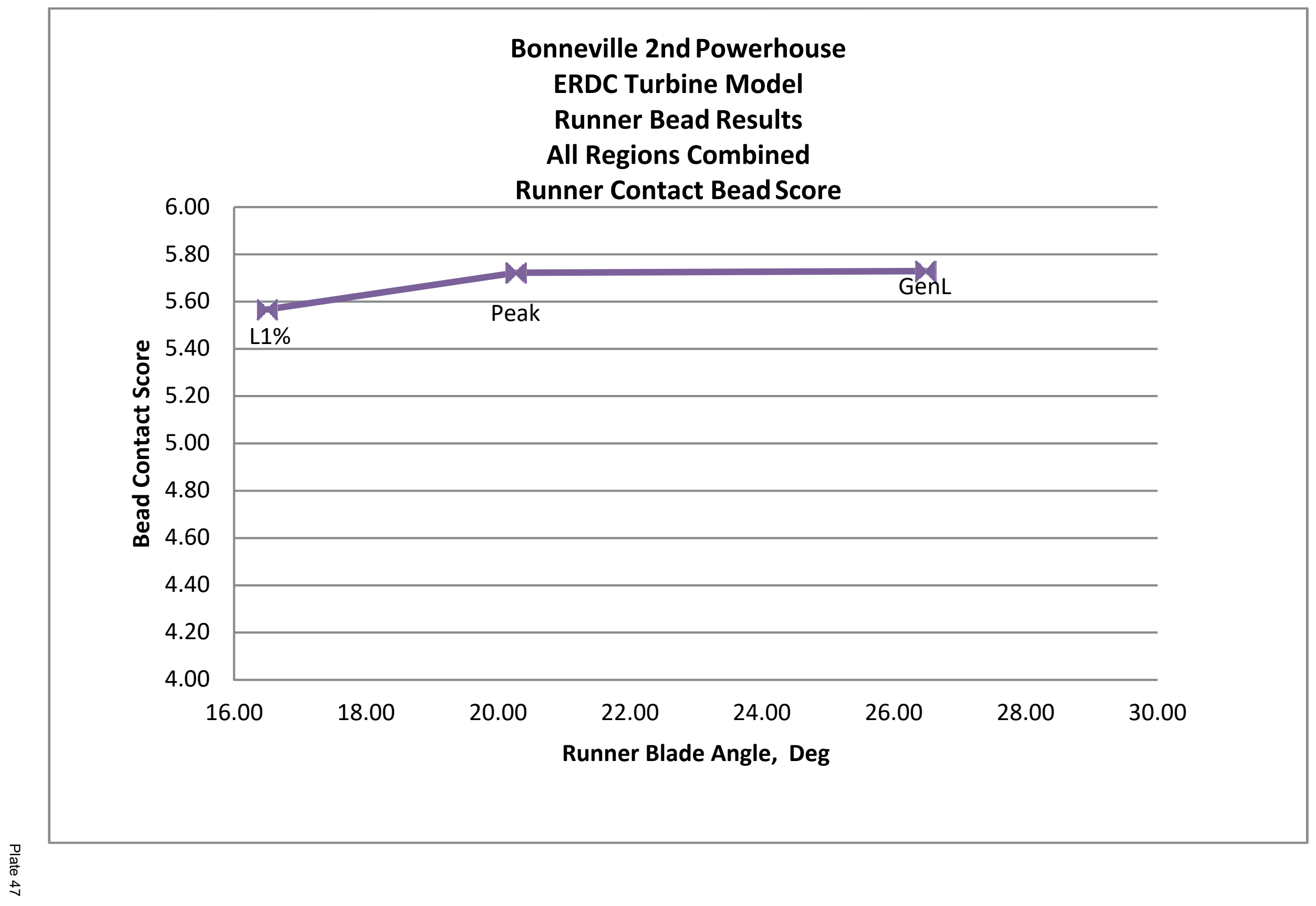




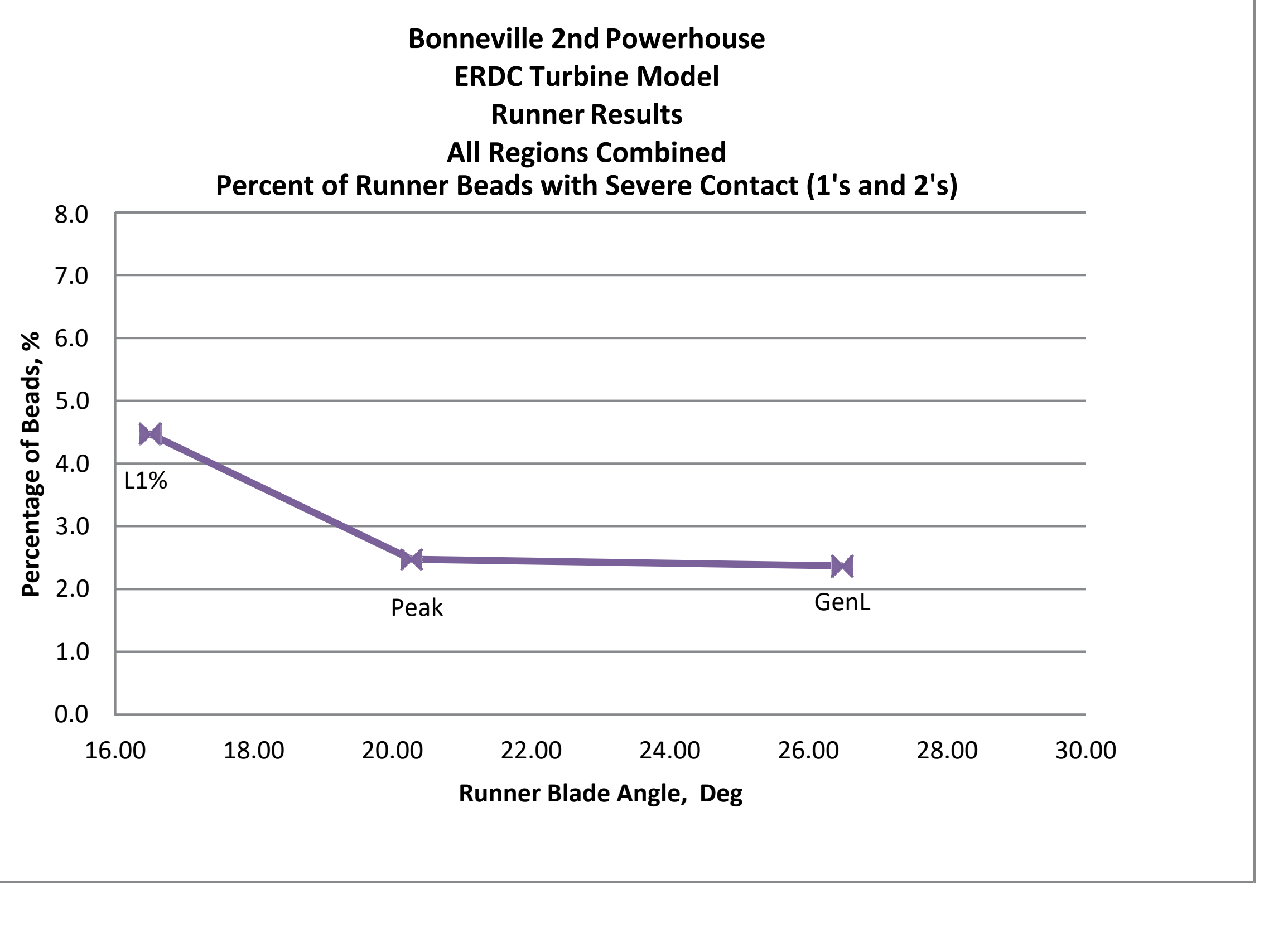




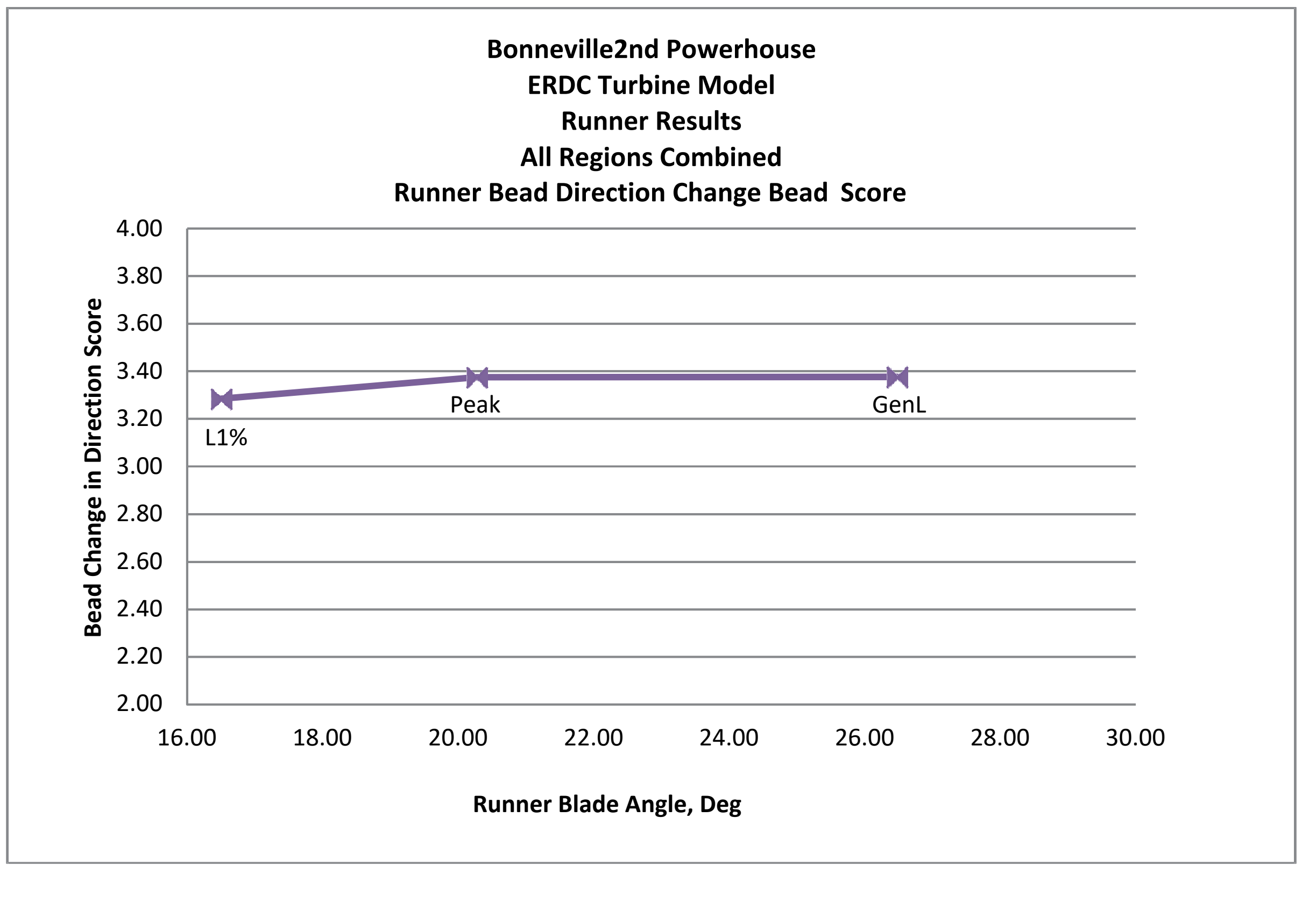




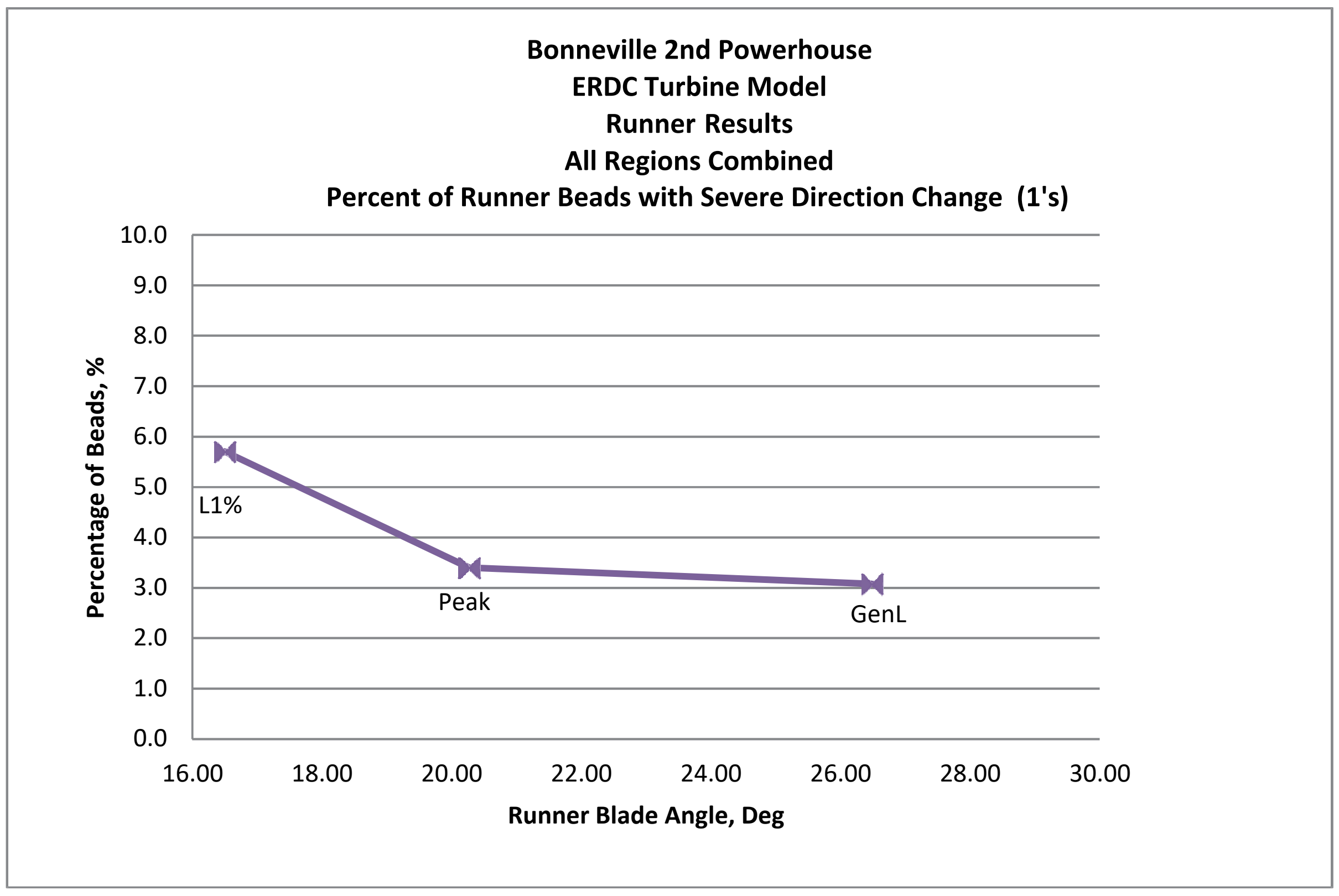




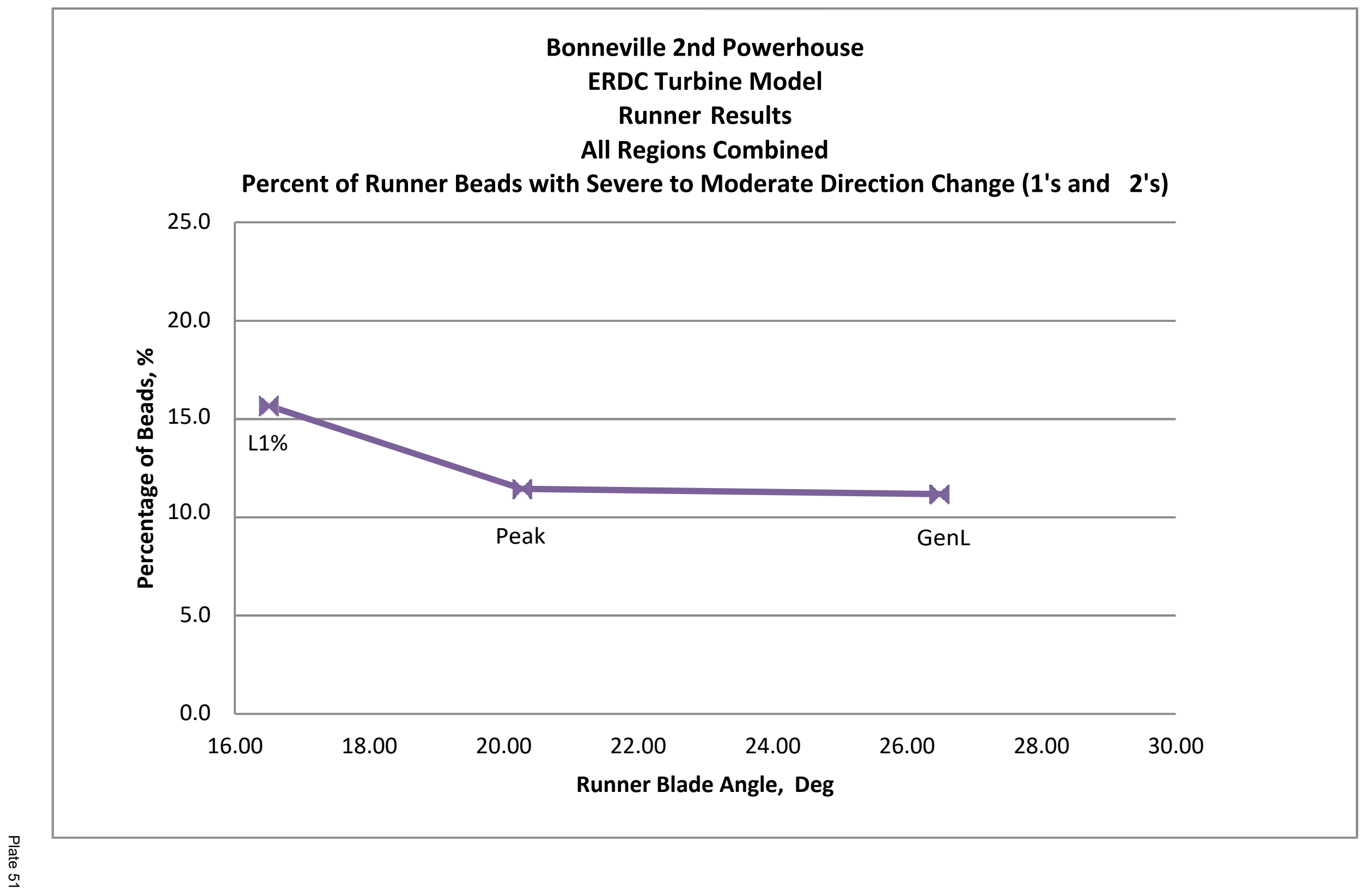



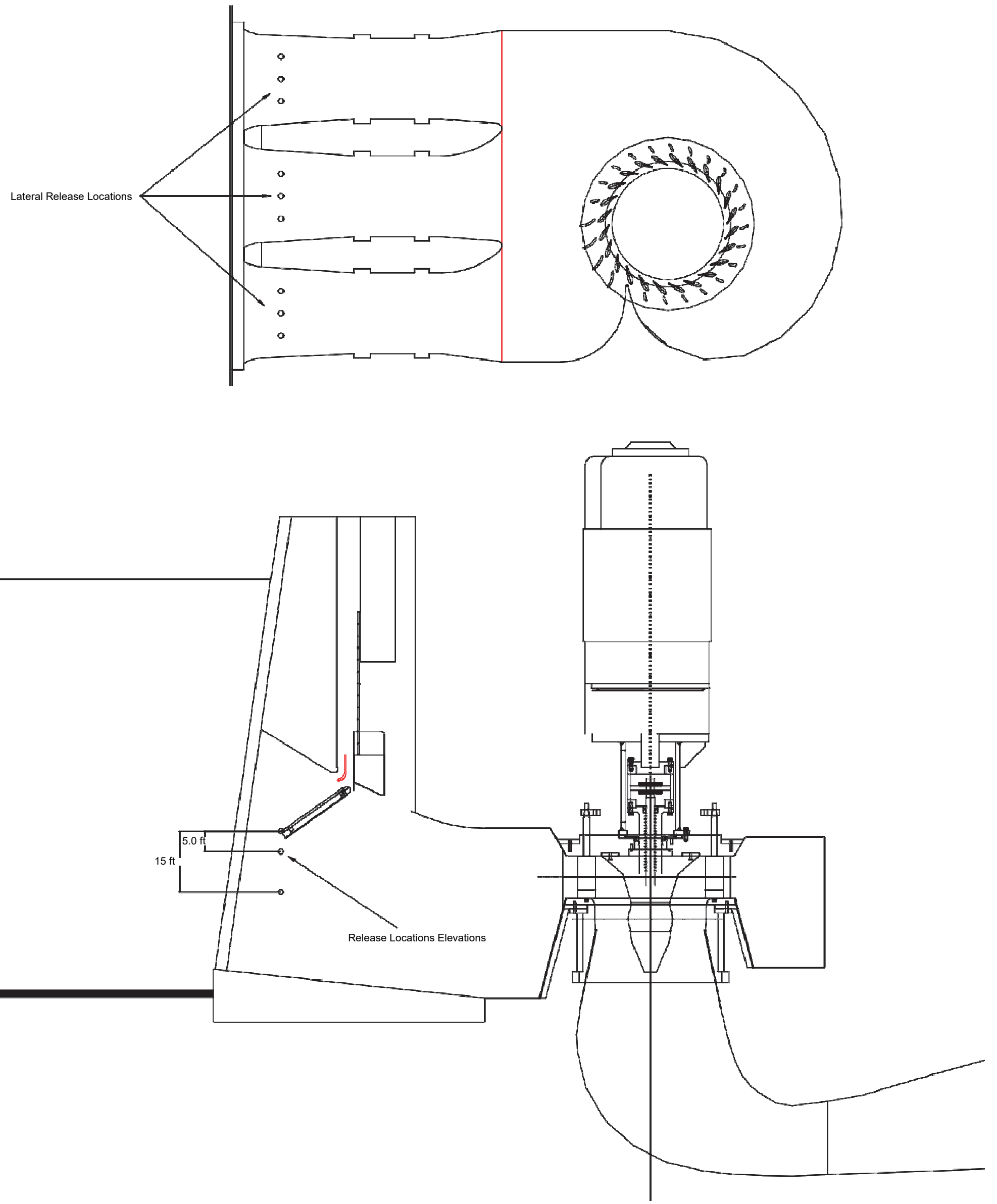


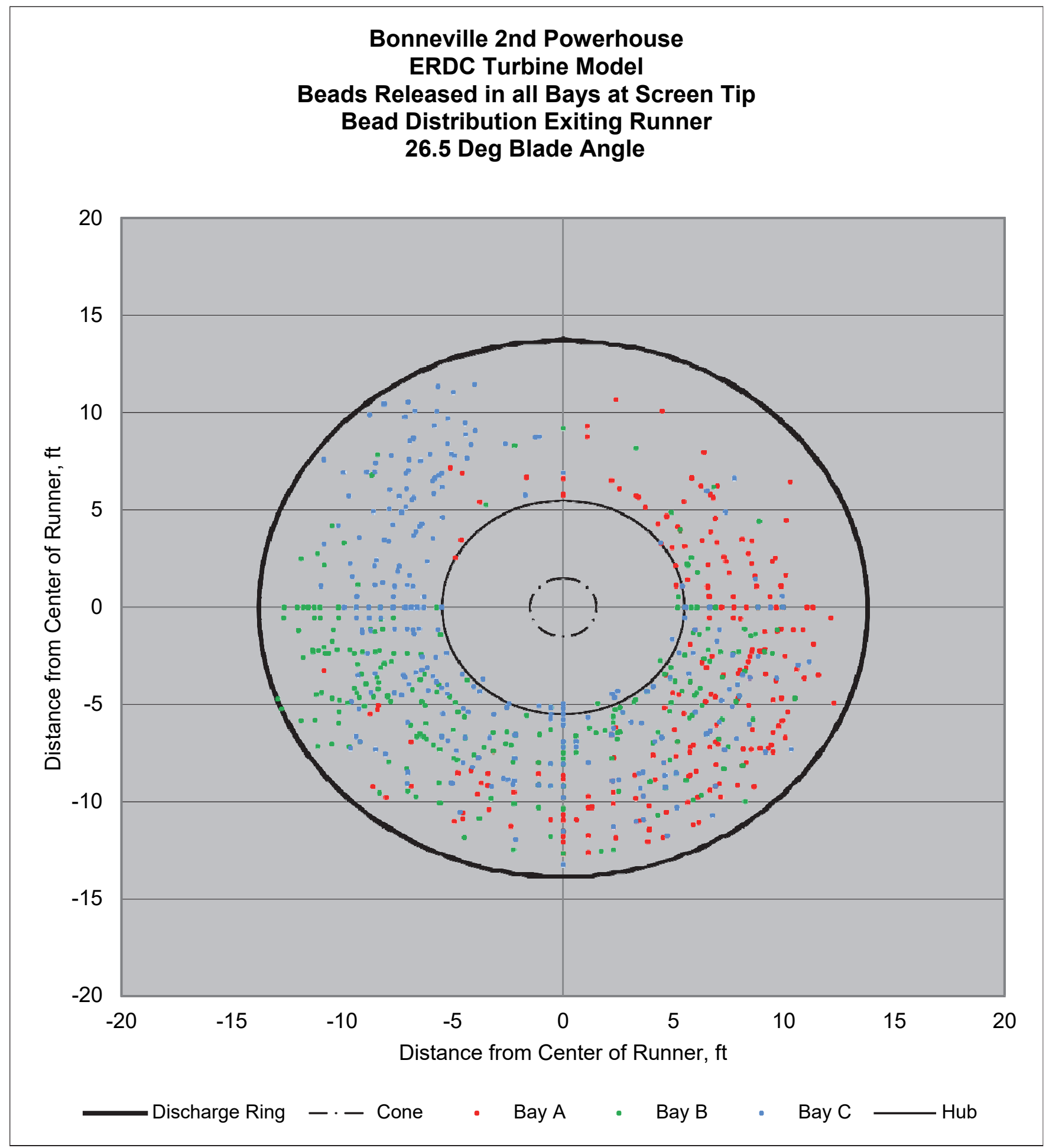




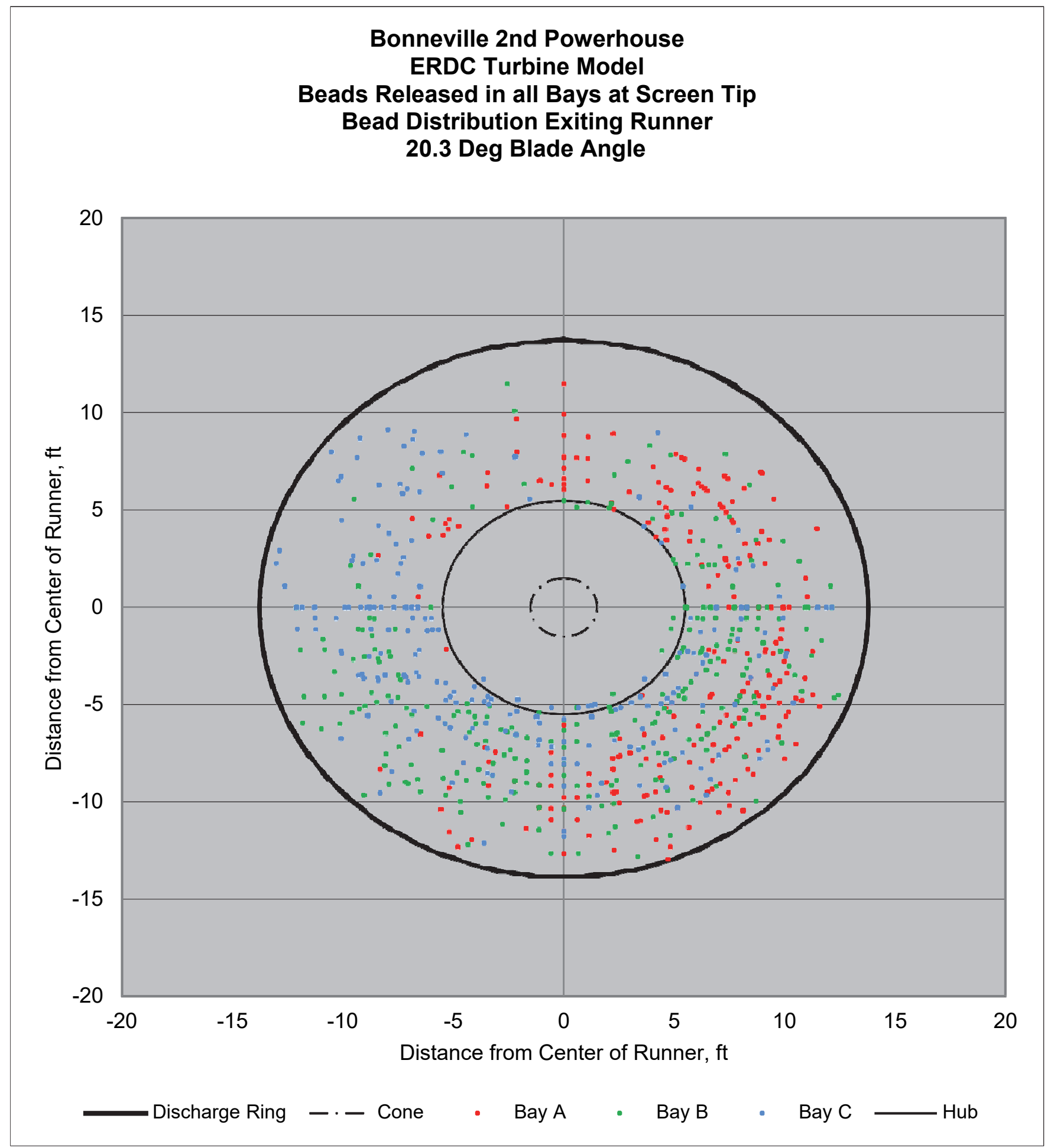




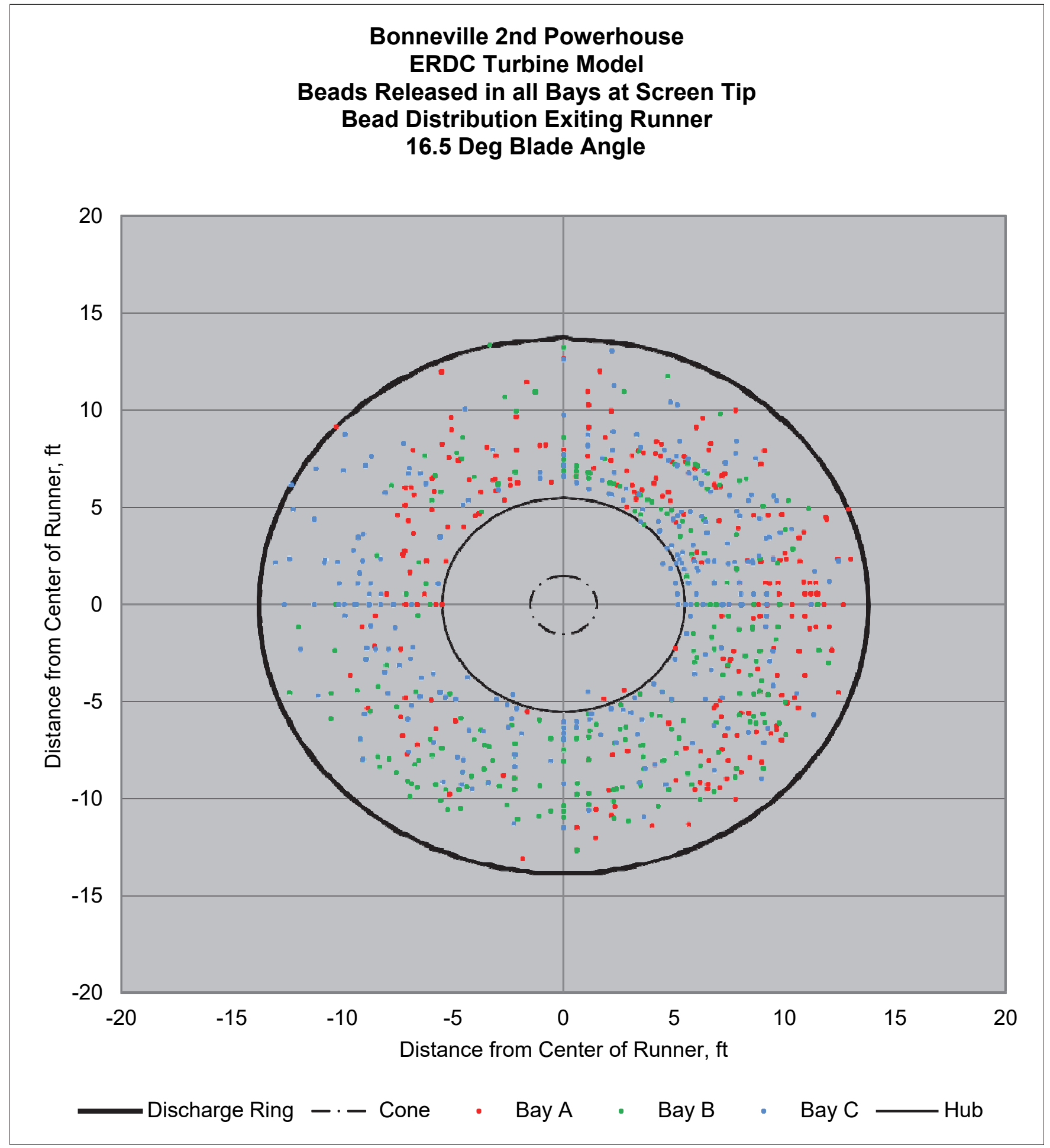


Bonneville 2nd Powherhouse ERDC Turbine Model

Runner Passage Location Results

$$
55 \mathrm{ft} \text { Head }
$$

Position 1 - Tip of STS

\begin{tabular}{|c|c|c|c|c|c|c|c|c|c|c|c|c|}
\hline & $\begin{array}{l}\text { Blade } \\
\text { Angle, } \\
\text { Deg }\end{array}$ & $\begin{array}{c}\text { Target } \\
\text { Discharge, } \\
\text { cfs }\end{array}$ & \begin{tabular}{|l} 
Average \\
Radial \\
Location
\end{tabular} & $\begin{array}{l}\text { Mean } \\
\text { Radial } \\
\text { Location }\end{array}$ & $\begin{array}{l}\text { Standard } \\
\text { Deviation }\end{array}$ & $\begin{array}{l}\text { Percentage of } \\
\text { Gap Passage }\end{array}$ & $\begin{array}{c}\text { Percentage of } \\
\text { beads within } 18 \\
\text { inches of hub }\end{array}$ & $\begin{array}{c}\begin{array}{c}\text { Percentage of } \\
\text { beads within } \\
24 \text { inches of } \\
\text { hub }\end{array} \\
\end{array}$ & $\begin{array}{c}\text { Percentage of } \\
\text { beads Passing } \\
\text { Mid Blade }(24 ")\end{array}$ & \begin{tabular}{|c|}
$\begin{array}{c}\text { Percentage of } \\
\text { beads within }\end{array}$ \\
$\begin{array}{c}18 \text { inches of } \\
\text { Tip }\end{array}$ \\
\end{tabular} & $\begin{array}{c}\text { Percentage of } \\
\text { beads within } \\
24 \text { inches of } \\
\text { Tip } \\
\end{array}$ & \# Beads \\
\hline Bay A & 26.5 & 19,115 & 9.44 & 9.52 & 1.99 & 0.3 & 18.0 & 19.3 & 72.0 & 4.7 & 8.7 & 300 \\
\hline Bay B & 26.5 & 19,115 & 8.85 & 8.83 & 2.04 & 0.3 & 25.0 & 32.3 & 60.3 & 5.0 & 7.3 & 300 \\
\hline Bay C & 26.5 & 19,115 & 8.52 & 8.83 & 1.99 & 0.3 & 29.7 & 34.3 & 60.3 & 3.0 & 5.3 & 300 \\
\hline Combined & 26.5 & 19,115 & 8.94 & 9.19 & 2.03 & 0.3 & 24.2 & 28.7 & 64.2 & 4.2 & 7.1 & 900 \\
\hline Bay A & 20.3 & 14,925 & 9.16 & 9.19 & 1.85 & 1.0 & 17.3 & 20.7 & 72.7 & 5.3 & 6.7 & 300 \\
\hline Bay B & 20.3 & 14,925 & 8.67 & 8.83 & 2.01 & 1.7 & 27.7 & 33.3 & 60.7 & 4.0 & 6.0 & 300 \\
\hline Bay C & 20.3 & 14,925 & 8.37 & 8.04 & 2.07 & 2.0 & 33.0 & 38.0 & 55.0 & 3.0 & 7.0 & 300 \\
\hline Combined & 20.3 & 14,925 & 8.73 & 8.83 & 2.00 & 1.6 & 26.0 & 30.7 & 62.8 & 4.1 & 6.6 & 900 \\
\hline Bay A & 16.5 & 11,280 & 9.31 & 9.19 & 1.89 & 1.0 & 14.3 & 19.3 & 71.7 & 5.7 & 9.0 & 300 \\
\hline Bay B & 16.5 & 11,280 & 8.79 & 8.83 & 1.88 & 0.7 & 27.7 & 35.0 & 60.3 & 2.3 & 4.7 & 300 \\
\hline Bay C & 16.5 & 11,280 & 8.47 & 8.62 & 2.03 & 3.0 & 30.7 & 39.0 & 55.0 & 4.0 & 6.0 & 300 \\
\hline Combined & 16.5 & 11,280 & 8.86 & 8.83 & 1.96 & 1.6 & 24.2 & 31.1 & 62.3 & 4.0 & 6.6 & 900 \\
\hline
\end{tabular}




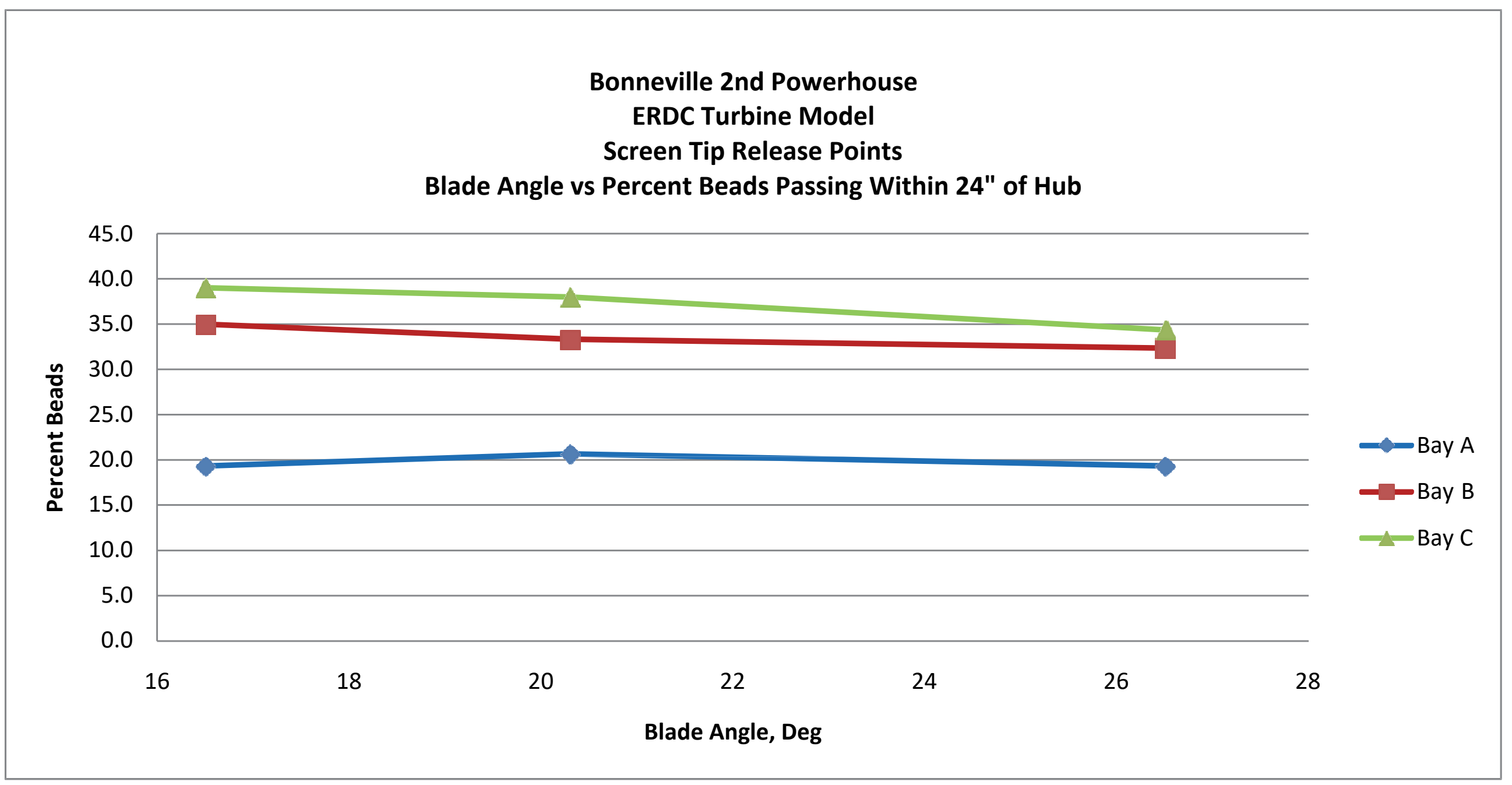




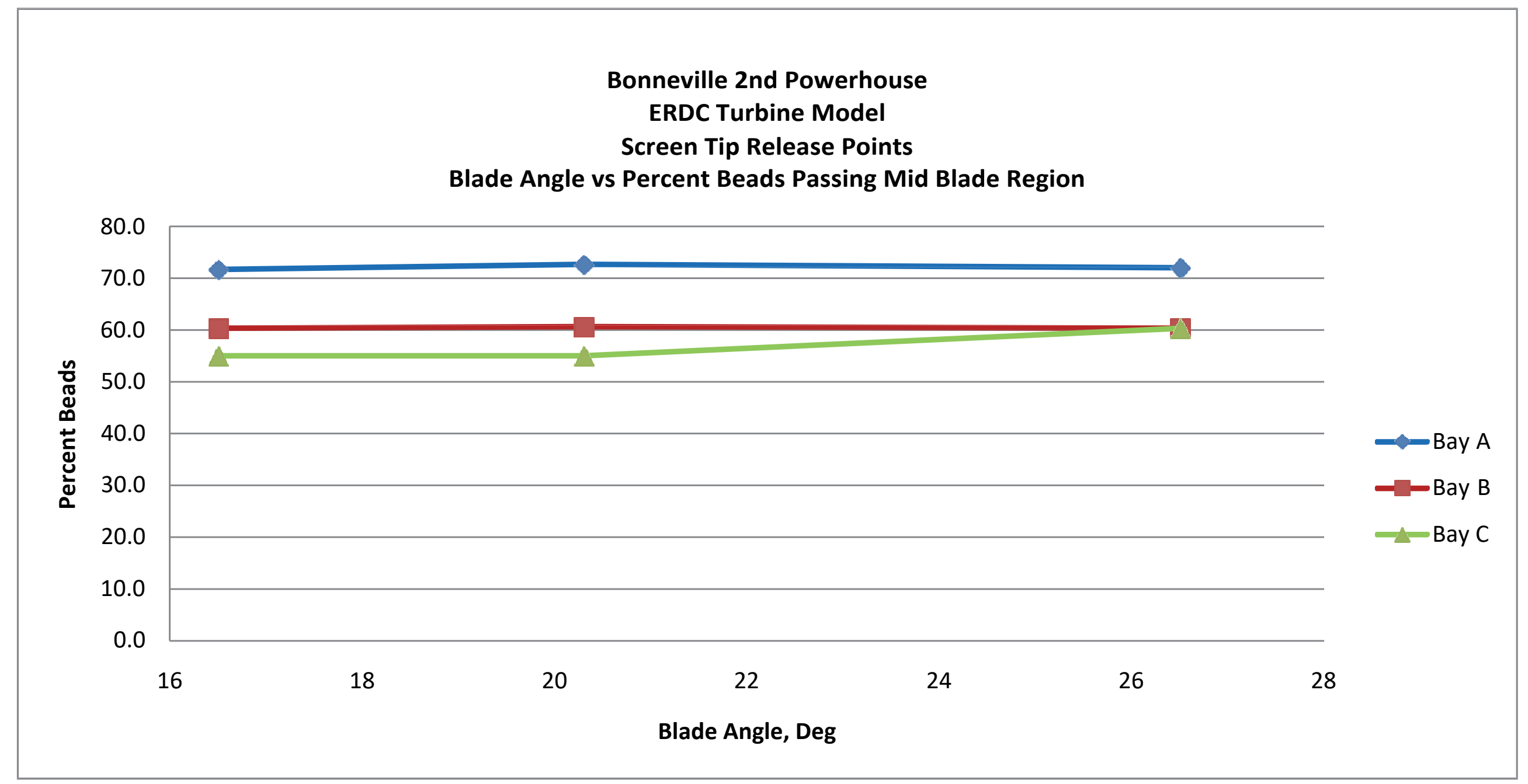




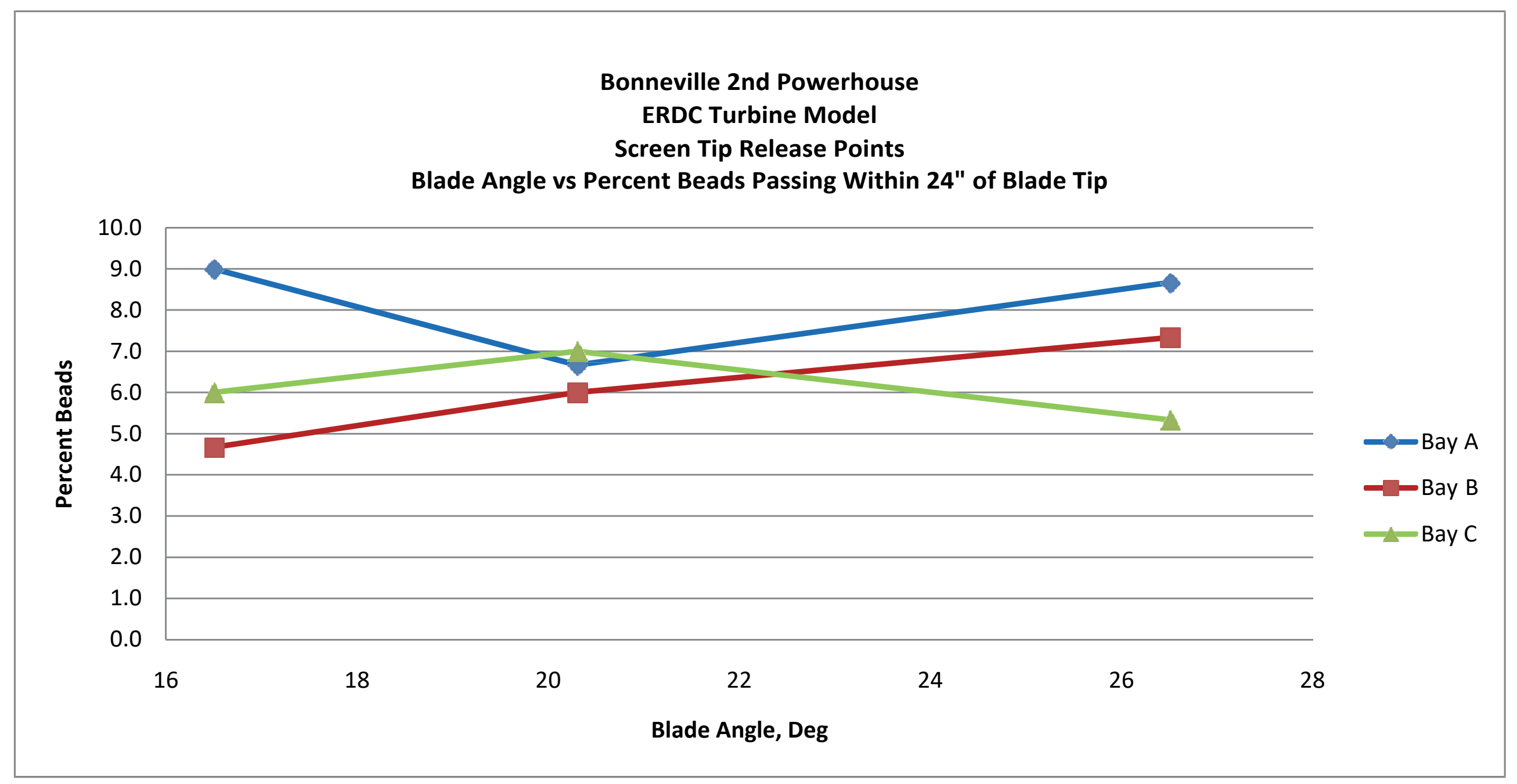




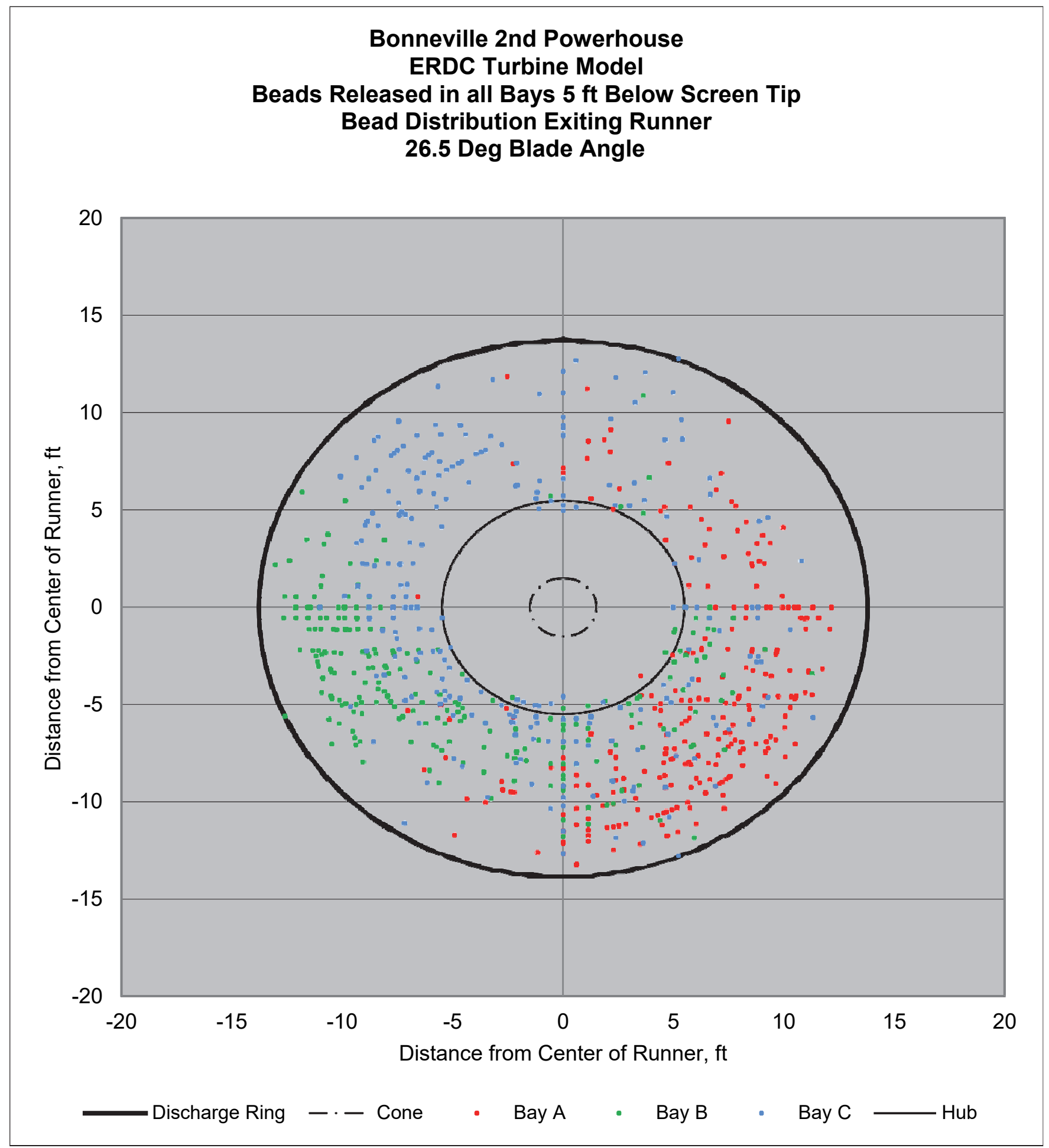




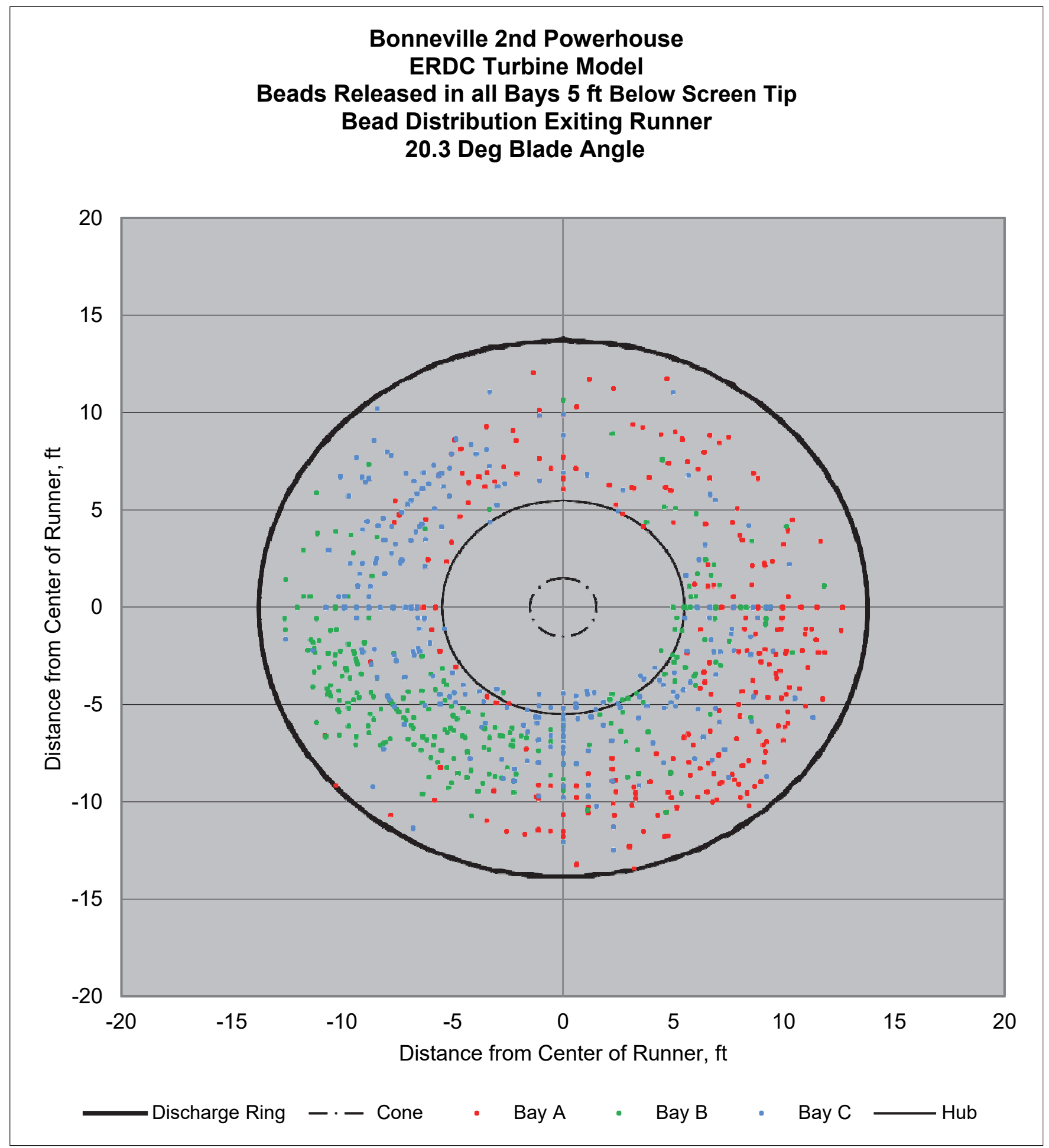




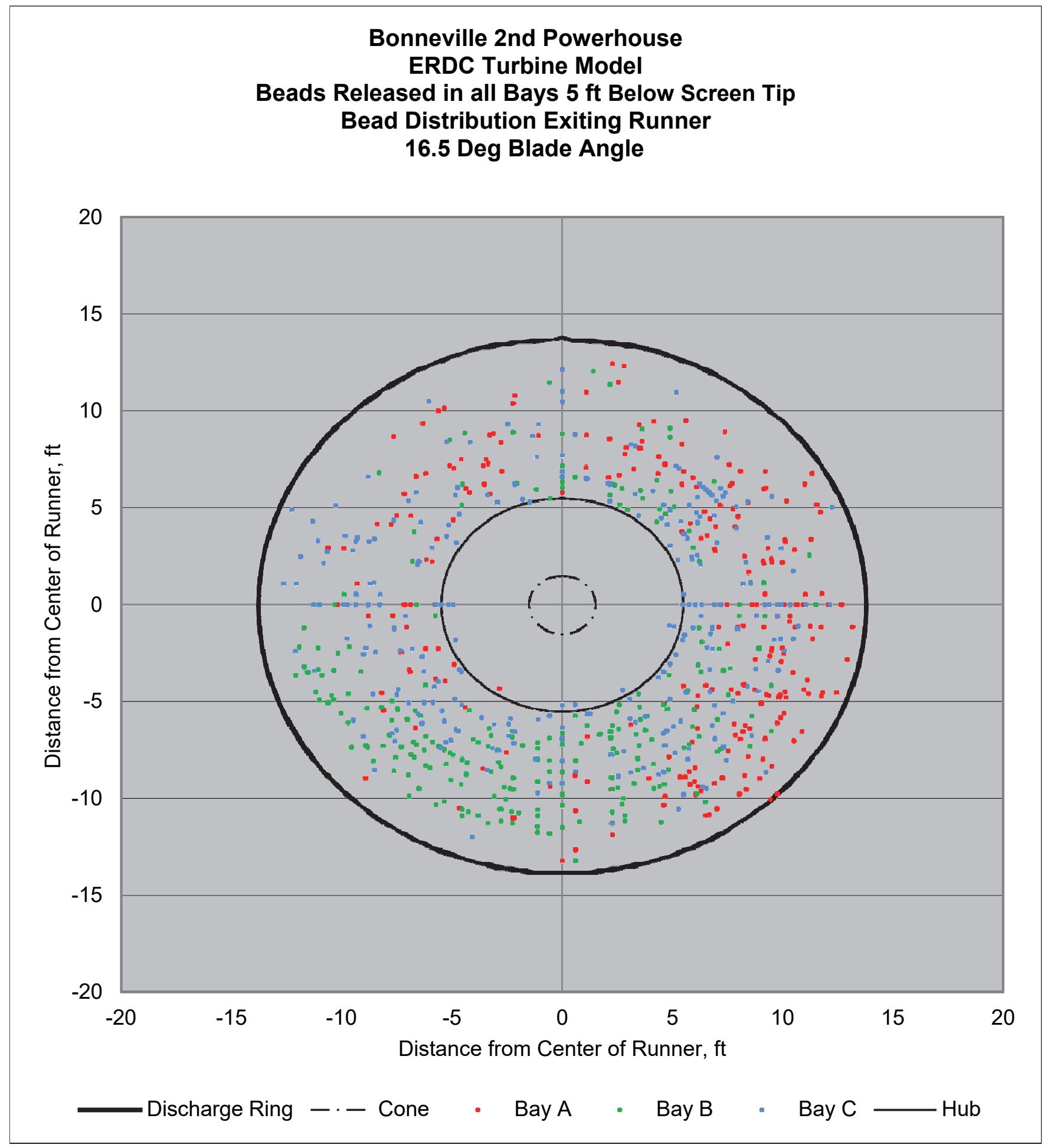


Bonneville 2nd Powerhouse ERDC Turbine Model

Runner Passage Location Results

55 FT Head

Position 2 - $5 \mathrm{ft}$ Below Tip of STS

\begin{tabular}{|c|c|c|c|c|c|c|c|c|c|c|c|c|}
\hline Release Bay & $\begin{array}{l}\text { Blade } \\
\text { Angle, } \\
\text { Deg }\end{array}$ & $\begin{array}{c}\text { Target } \\
\text { Discharge, } \\
\text { cfs }\end{array}$ & $\begin{array}{l}\text { Average } \\
\text { Radial } \\
\text { Location }\end{array}$ & $\begin{array}{l}\text { Mean } \\
\text { Radial } \\
\text { Location }\end{array}$ & Std dev & $\begin{array}{l}\text { Percentage of } \\
\text { Gap Passage }\end{array}$ & $\begin{array}{c}\text { Percentage of } \\
\text { beads within } 18 \\
\text { inches of hub }\end{array}$ & $\begin{array}{c}\begin{array}{c}\text { Percentage of } \\
\text { beads within } \\
24 \text { inches of } \\
\text { hub }\end{array} \\
\end{array}$ & $\begin{array}{c}\text { Percentage of } \\
\text { beads Passing } \\
\text { Mid Blade (24") }\end{array}$ & $\begin{array}{c}\text { Percentage of } \\
\text { beads within } \\
18 \text { inches of } \\
\text { Tip }\end{array}$ & $\begin{array}{c}\text { Percentage of } \\
\text { beads within } \\
24 \text { inches of } \\
\text { Tip } \\
\end{array}$ & \# Beads \\
\hline Bay A & 26.5 & 19,115 & 9.64 & 9.77 & 1.89 & 0.7 & 12.0 & 15.0 & 76.0 & 5.3 & 9.0 & 300 \\
\hline Bay B & 26.5 & 19,115 & 9.01 & 9.19 & 1.91 & 0.0 & 23.0 & 26.7 & 67.3 & 2.7 & 6.0 & 300 \\
\hline Bay C & 26.5 & 19,115 & 8.53 & 8.83 & 2.05 & 0.3 & 30.3 & 36.7 & 55.3 & 3.3 & 8.0 & 300 \\
\hline Combined & 26.5 & 19,115 & 9.06 & 9.19 & 2.04 & 0.3 & 21.8 & 26.1 & 66.2 & 3.8 & 7.7 & 900 \\
\hline Bay A & 20.3 & 14,925 & 9.53 & 9.77 & 1.94 & 2.3 & 13.3 & 17.3 & 73.0 & 6.3 & 9.7 & 300 \\
\hline Bay B & 20.3 & 14,925 & 8.80 & 9.19 & 1.93 & 2.0 & 24.0 & 32.7 & 63.3 & 2.0 & 4.0 & 300 \\
\hline Bay C & 20.3 & 14,925 & 8.09 & 8.04 & 1.93 & 2.7 & 36.7 & 42.7 & 52.7 & 2.7 & 4.7 & 300 \\
\hline Combined & 20.3 & 14,925 & 8.81 & 9.19 & 2.02 & 2.3 & 24.7 & 30.9 & 63.0 & 3.7 & 6.1 & 900 \\
\hline Bay A & 16.5 & 11,280 & 9.70 & 9.77 & 1.87 & 1.0 & 9.3 & 16.0 & 71.7 & 10.3 & 12.3 & 300 \\
\hline Bay B & 16.5 & 11,280 & 9.06 & 9.19 & 1.83 & 1.0 & 20.3 & 28.7 & 67.0 & 0.7 & 4.3 & 300 \\
\hline Bay C & 16.5 & 11,280 & 8.34 & 8.27 & 1.89 & 3.3 & 32.7 & 37.0 & 58.3 & 1.7 & 4.7 & 300 \\
\hline Combined & 16.5 & 11,280 & 9.03 & 9.19 & 1.94 & 1.8 & 20.8 & 27.2 & 65.7 & 4.2 & 7.1 & 900 \\
\hline
\end{tabular}




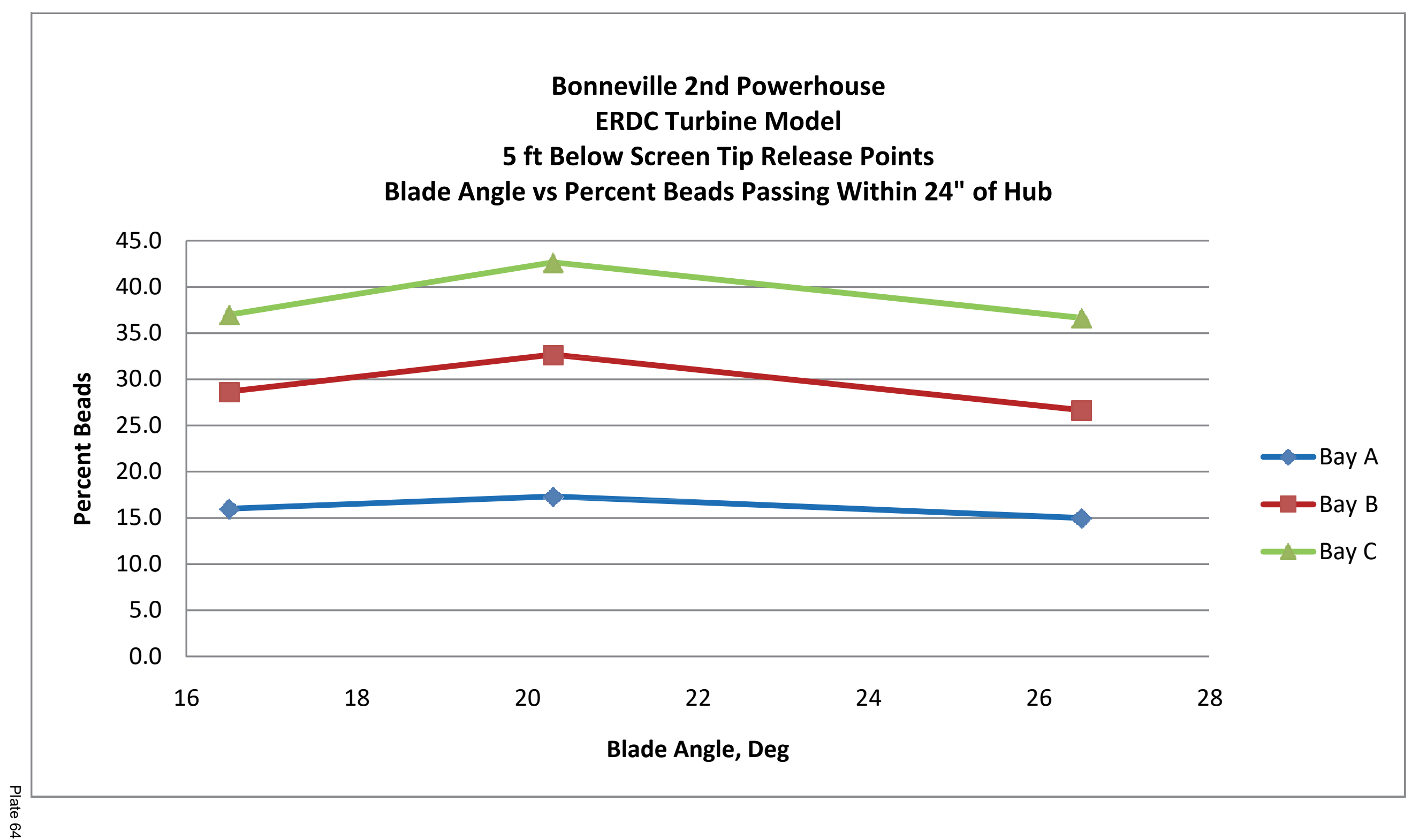




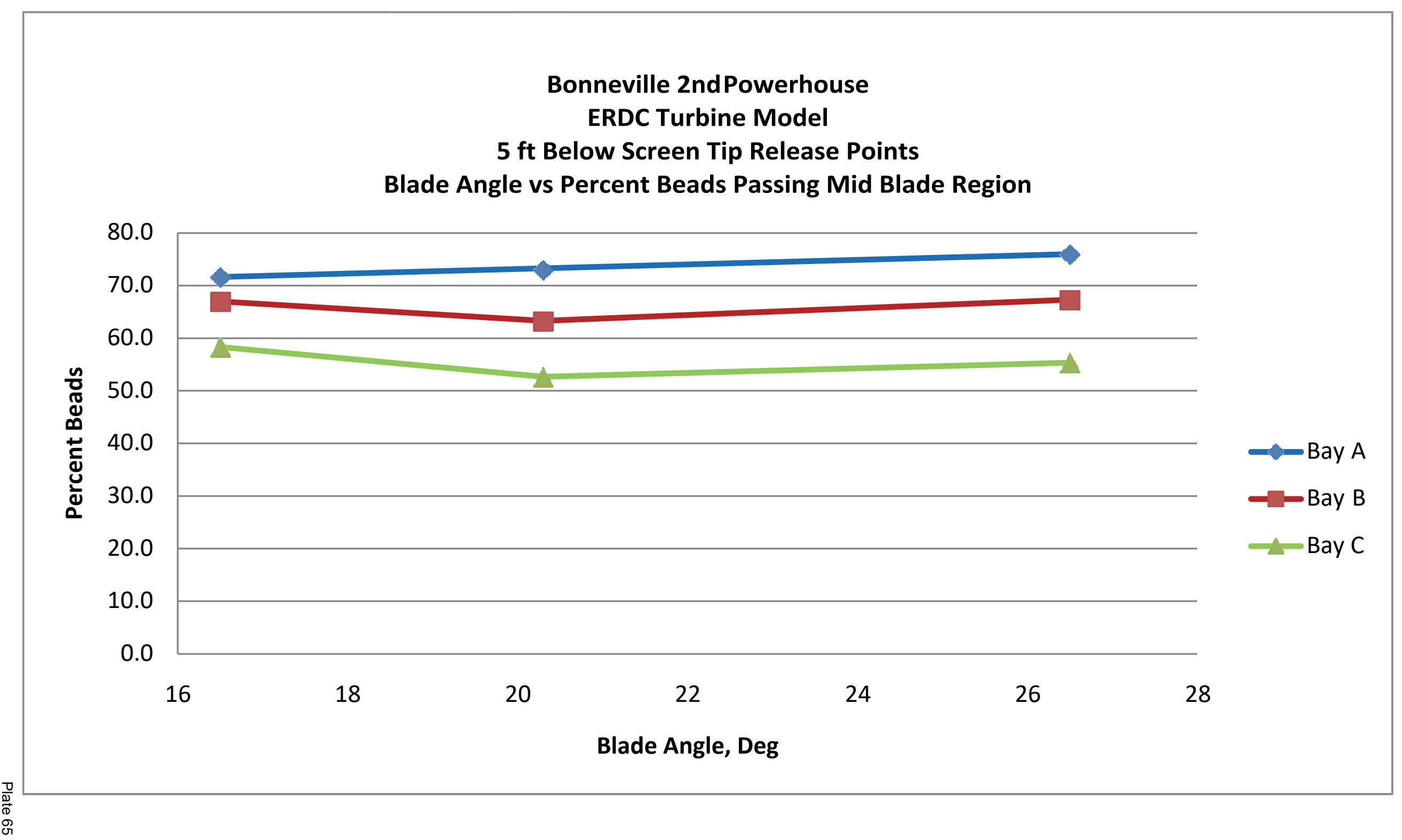




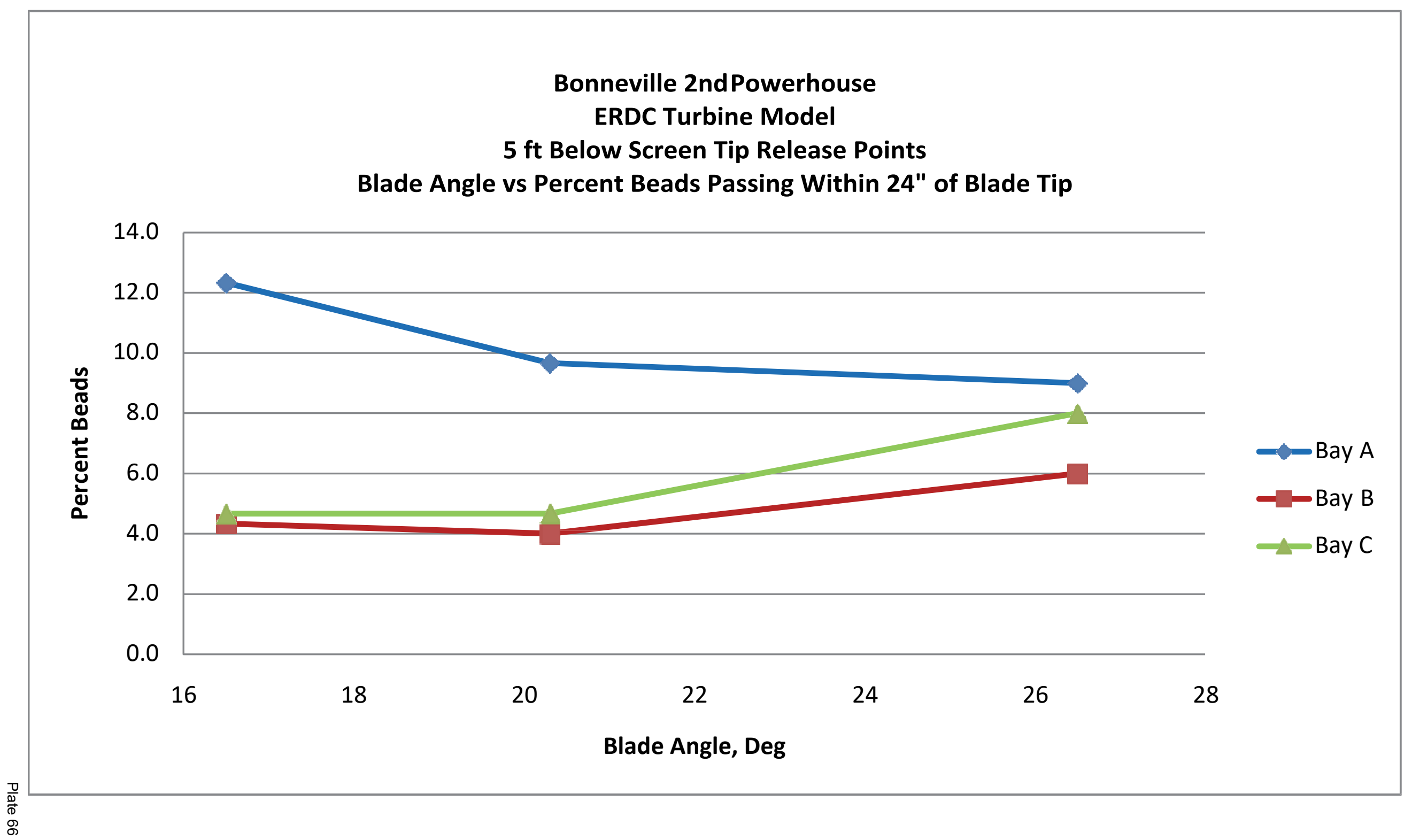




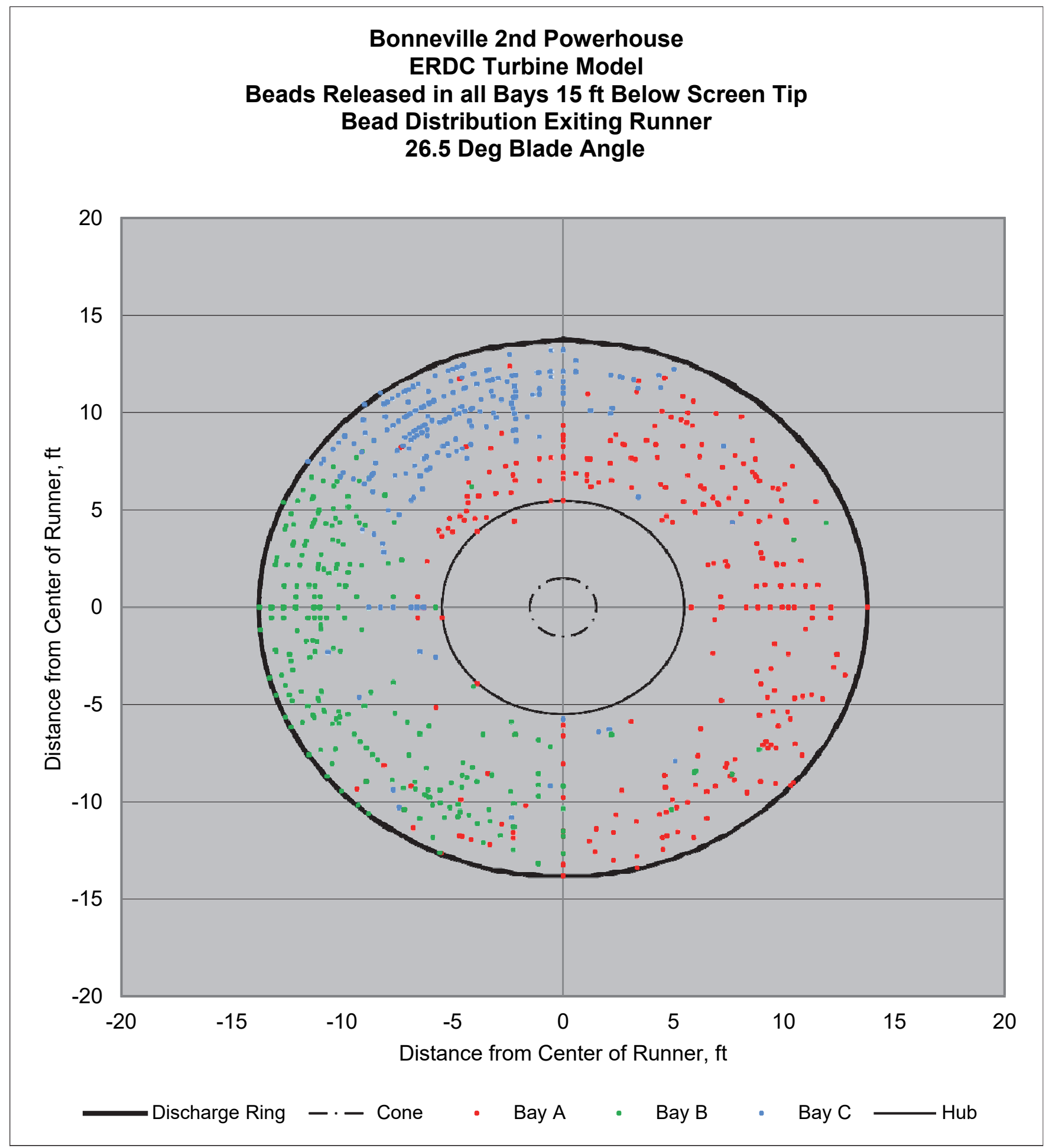




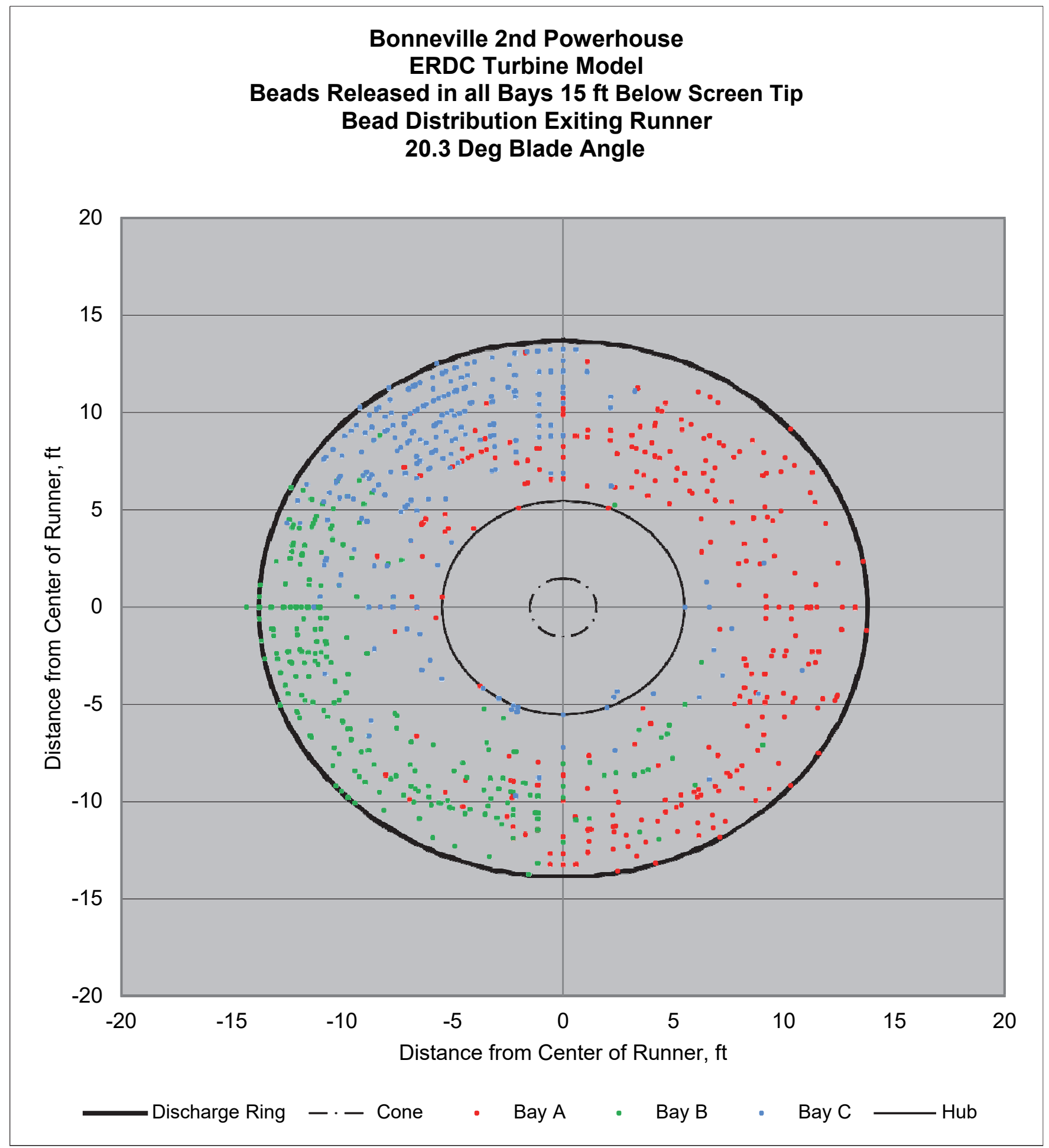




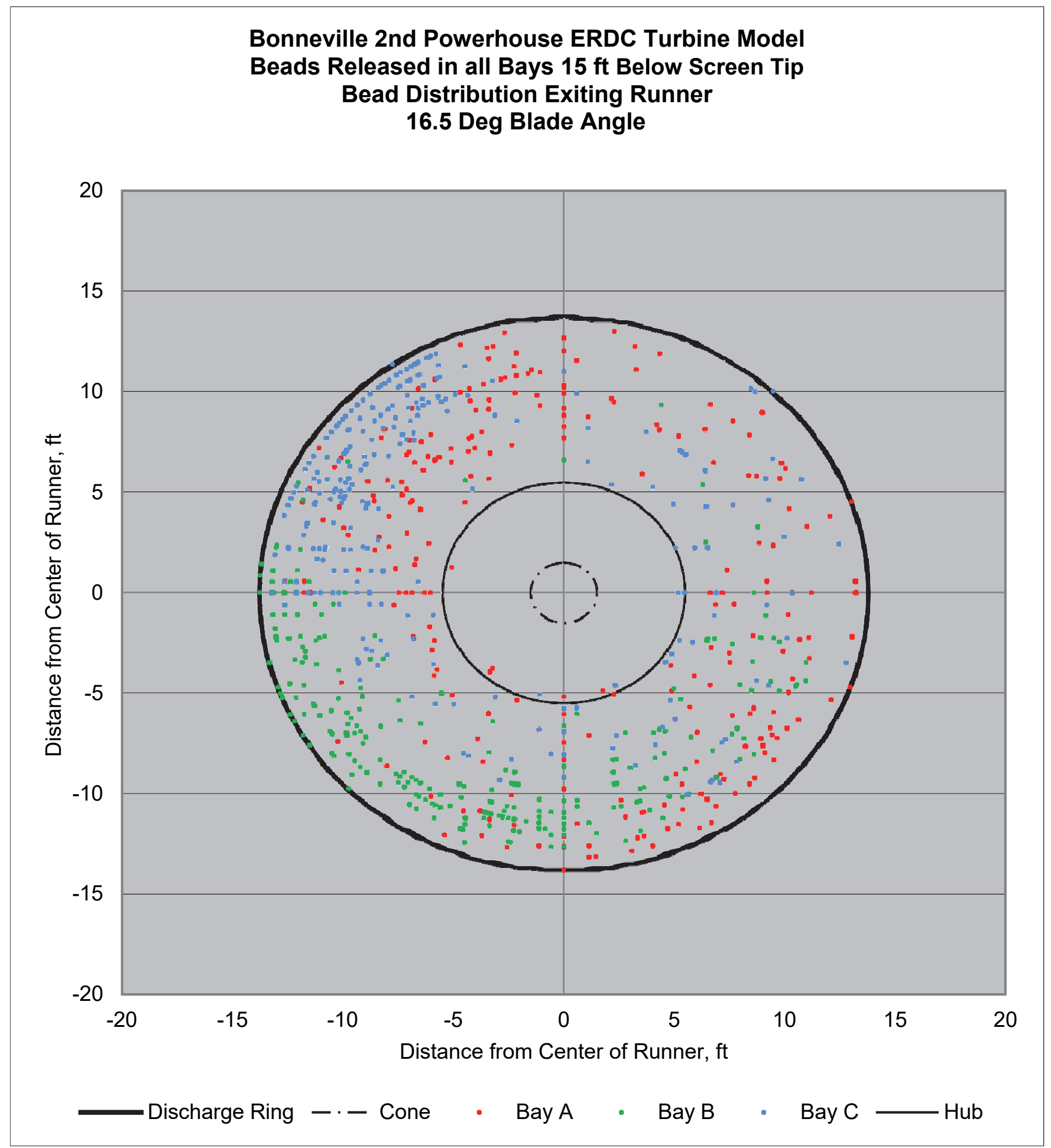


Bonneville 2nd Powerhouse ERDC Turbine Model

Runner Passage Location Results

$55 \mathrm{ft} \mathrm{Head}$

Position 3 - Tip of screen minus $15 \mathrm{ft}$

\begin{tabular}{|c|c|c|c|c|c|c|c|c|c|c|c|c|}
\hline Release Bay & $\begin{array}{l}\text { Blade } \\
\text { Angle, } \\
\text { Deg }\end{array}$ & $\begin{array}{c}\text { Target } \\
\text { Discharge, } \\
\text { cfs }\end{array}$ & $\begin{array}{c}\text { Average } \\
\text { Radial } \\
\text { Location }\end{array}$ & $\begin{array}{l}\text { Mean } \\
\text { Radial } \\
\text { Location }\end{array}$ & $\begin{array}{l}\text { Standard } \\
\text { Deviation }\end{array}$ & $\begin{array}{l}\text { Percentage of } \\
\text { Gap Passage }\end{array}$ & $\begin{array}{c}\text { Percentage } \\
\text { of beads } \\
\text { within } 18 \\
\text { inches of hub }\end{array}$ & $\begin{array}{c}\text { Percentage of } \\
\text { beads within } \\
24 \text { inches of } \\
\text { hub }\end{array}$ & $\begin{array}{c}\text { Percentage of } \\
\text { beads passing } \\
\text { mid Blade }\end{array}$ & $\begin{array}{c}\text { Percentage of } \\
\text { beads within } \\
18 \text { inches of } \\
\text { Tip }\end{array}$ & $\begin{array}{c}\text { Percentage } \\
\text { of beads } \\
\text { within } 24 \\
\text { inches of Tip }\end{array}$ & \# Beads \\
\hline Bay A & 26.5 & 19,115 & 9.87 & 10.07 & 1.86 & 1.7 & 16.3 & 18.7 & 62.0 & 15.0 & 19.3 & 300 \\
\hline Bay B & 26.5 & 19,115 & 11.47 & 11.49 & 1.54 & 0.3 & 2.0 & 3.0 & 53.3 & 29.0 & 43.7 & 300 \\
\hline Bay C & 26.5 & 19,115 & 11.16 & 11.31 & 1.62 & 0.3 & 4.7 & 4.7 & 54.7 & 19.7 & 40.7 & 300 \\
\hline Combined & 26.5 & 19,115 & 10.83 & 11.31 & 1.94 & 0.8 & 7.7 & 8.8 & 56.7 & 21.2 & 34.6 & 900 \\
\hline Bay A & 20.3 & 14,925 & 10.19 & 10.27 & 1.99 & 0.0 & 7.3 & 9.3 & 70.0 & 17.7 & 20.7 & 300 \\
\hline Bay B & 20.3 & 14,925 & 11.43 & 11.58 & 1.60 & 0.7 & 1.0 & 2.0 & 54.3 & 30.0 & 43.7 & 300 \\
\hline Bay C & 20.3 & 14,925 & 10.71 & 11.03 & 2.10 & 1.7 & 7.7 & 9.0 & 54.3 & 21.0 & 36.7 & 300 \\
\hline Combined & 20.3 & 14,925 & 10.78 & 11.03 & 1.97 & 0.8 & 5.3 & 6.8 & 59.6 & 22.9 & 33.7 & 900 \\
\hline Bay A & 16.5 & 11,280 & 10.26 & 10.48 & 2.13 & 1.7 & 9.7 & 14.0 & 61.3 & 19.3 & 24.7 & 300 \\
\hline Bay B & 16.5 & 11,280 & 11.26 & 11.49 & 1.69 & 0.3 & 3.0 & 5.3 & 53.3 & 26.7 & 41.3 & 300 \\
\hline Bay C & 16.5 & 11,280 & 10.72 & 11.31 & 2.22 & 1.0 & 12.0 & 12.3 & 49.4 & 27.3 & 38.3 & 300 \\
\hline Combined & 16.5 & 11,280 & 10.75 & 11.31 & 2.07 & 1.0 & 8.2 & 10.5 & 54.7 & 24.4 & 34.8 & 900 \\
\hline
\end{tabular}




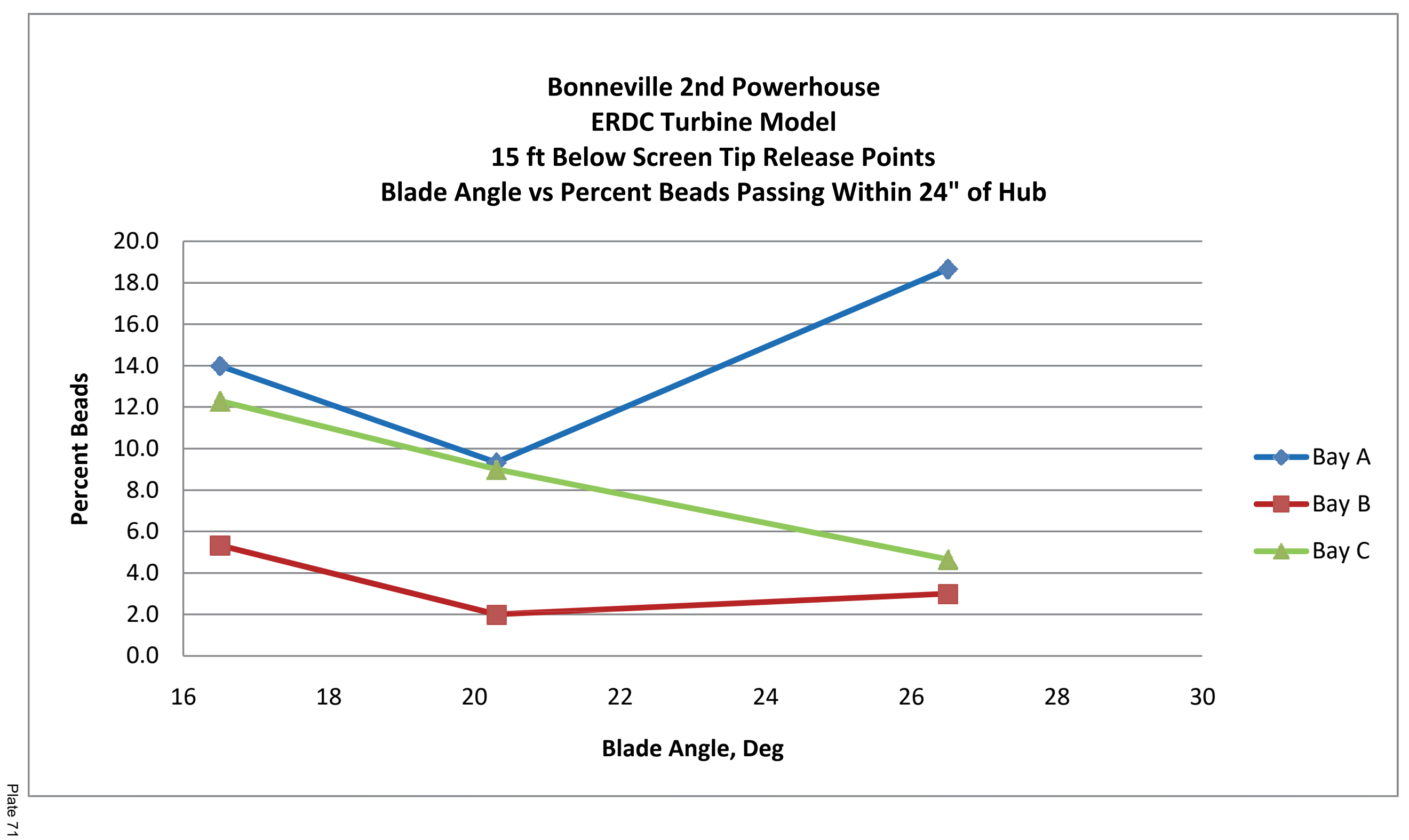




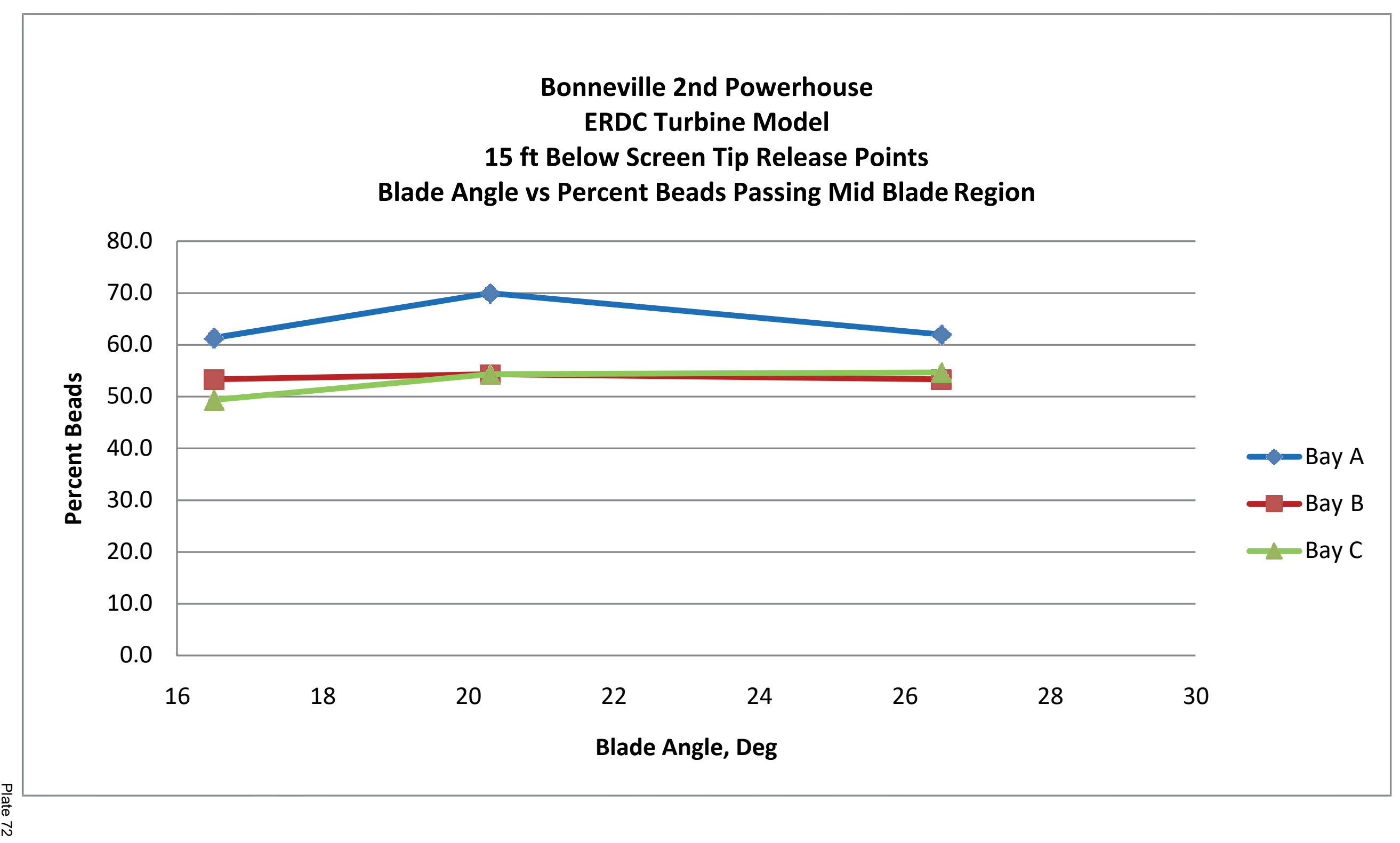




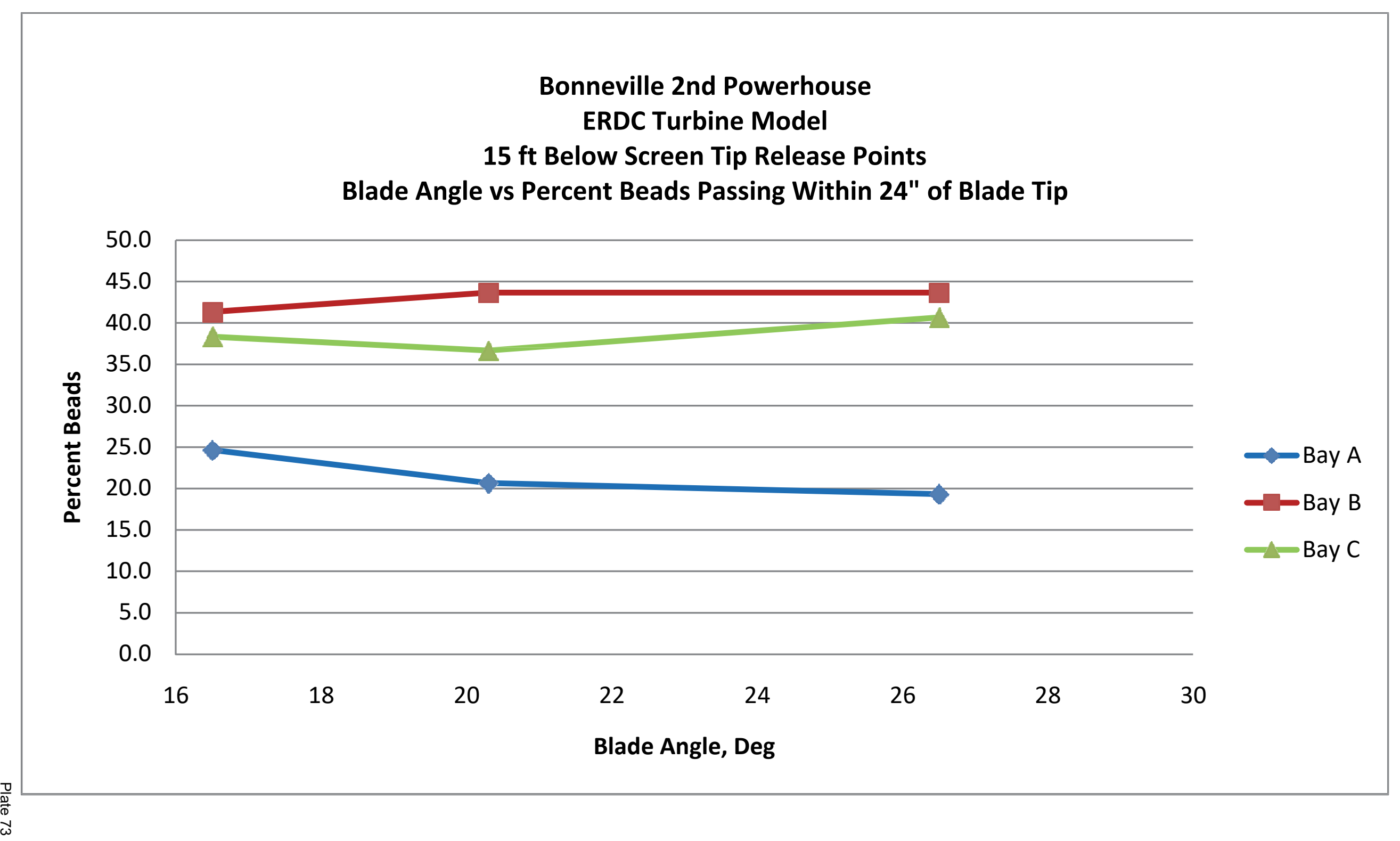


Bonneville 2nd Powerhouse ERDC Turbine Model

Runner Passage Location Results

$55 \mathrm{ft} \mathrm{Head}$

Average of Top 2 Release Elevations

\begin{tabular}{|c|c|c|c|c|c|c|c|c|c|c|c|c|}
\hline $\begin{array}{l}\text { Release } \\
\text { Bay }\end{array}$ & $\begin{array}{l}\text { Blade } \\
\text { Angle, } \\
\text { Deg }\end{array}$ & $\begin{array}{c}\text { Target } \\
\text { Discharge, cfs }\end{array}$ & $\begin{array}{l}\text { Average } \\
\text { Radial } \\
\text { Location }\end{array}$ & $\begin{array}{l}\text { Mean } \\
\text { Radial } \\
\text { Location }\end{array}$ & $\begin{array}{l}\text { Standard } \\
\text { Deviation }\end{array}$ & $\begin{array}{l}\text { Percentage of } \\
\text { Gap Passage }\end{array}$ & $\begin{array}{c}\text { Percentage of } \\
\text { beads within } \\
\begin{array}{c}18 \text { inches of } \\
\text { hub }\end{array} \\
\end{array}$ & $\begin{array}{c}\text { Percentage of } \\
\text { beads within } \\
24 \text { inches of } \\
\text { hub }\end{array}$ & $\begin{array}{c}\text { Percentage of } \\
\text { beads passing } \\
\text { mid Blade }\end{array}$ & $\begin{array}{c}\text { Percentage of } \\
\text { beads within } 18 \\
\text { inches of Tip }\end{array}$ & $\begin{array}{c}\text { Percentage of } \\
\text { beads within } 24 \\
\text { inches of Tip }\end{array}$ & \# Beads \\
\hline All & 26.5 & 19,115 & 9.0 & 9.2 & 2.04 & 0.3 & 23.0 & 27.4 & 65.2 & 4.0 & 7.4 & 1800 \\
\hline All & 20.3 & 14,925 & 8.8 & 9.0 & 2.01 & 1.9 & 25.3 & 30.8 & 62.9 & 3.9 & 6.3 & 1800 \\
\hline All & 16.5 & 11,280 & 8.9 & 9.0 & 1.95 & 1.7 & 22.5 & 29.2 & 64.0 & 4.1 & 6.8 & 1800 \\
\hline
\end{tabular}

Bonneville 2nd Powerhouse ERDC Turbine Model

Runner Passage Location Results

$$
55 \mathrm{ft} \mathrm{Head}
$$

Average of Top 3 Release Elevations

\begin{tabular}{|c|c|c|c|c|c|c|c|c|c|c|c|c|}
\hline $\begin{array}{l}\text { Release } \\
\text { Bay }\end{array}$ & $\begin{array}{l}\text { Blade } \\
\text { Angle, } \\
\text { Deg }\end{array}$ & $\begin{array}{c}\text { Target } \\
\text { Discharge, cfs }\end{array}$ & $\begin{array}{l}\text { Average } \\
\text { Radial } \\
\text { Location }\end{array}$ & $\begin{array}{l}\text { Mean } \\
\text { Radial } \\
\text { Location }\end{array}$ & $\begin{array}{l}\text { Standard } \\
\text { Deviation }\end{array}$ & $\begin{array}{l}\text { Percentage of } \\
\text { Gap Passage }\end{array}$ & $\begin{array}{c}\text { Percentage of } \\
\text { beads within } \\
18 \text { inches of } \\
\text { hub }\end{array}$ & $\begin{array}{c}\text { Percentage of } \\
\text { beads within } \\
24 \text { inches of } \\
\text { hub }\end{array}$ & $\begin{array}{l}\text { Percentage of } \\
\text { beads passing } \\
\text { mid Blade }\end{array}$ & $\begin{array}{c}\text { Percentage of } \\
\text { beads within } 18 \\
\text { inches of Tip }\end{array}$ & $\begin{array}{c}\text { Percentage of } \\
\text { beads within } 24 \\
\text { inches of Tip }\end{array}$ & \# Beads \\
\hline All & 26.5 & 19,115 & 9.6 & 9.9 & 2.01 & 0.5 & 17.9 & 21.2 & 62.4 & 9.7 & 16.4 & 2700 \\
\hline All & 20.3 & 14,925 & 9.4 & 9.7 & 2.00 & 1.6 & 18.7 & 22.8 & 61.8 & 10.2 & 15.4 & 2700 \\
\hline All & 16.5 & 11,280 & 9.5 & 9.8 & 1.99 & 1.4 & 17.7 & 22.9 & 60.9 & 10.9 & 16.1 & 2700 \\
\hline
\end{tabular}




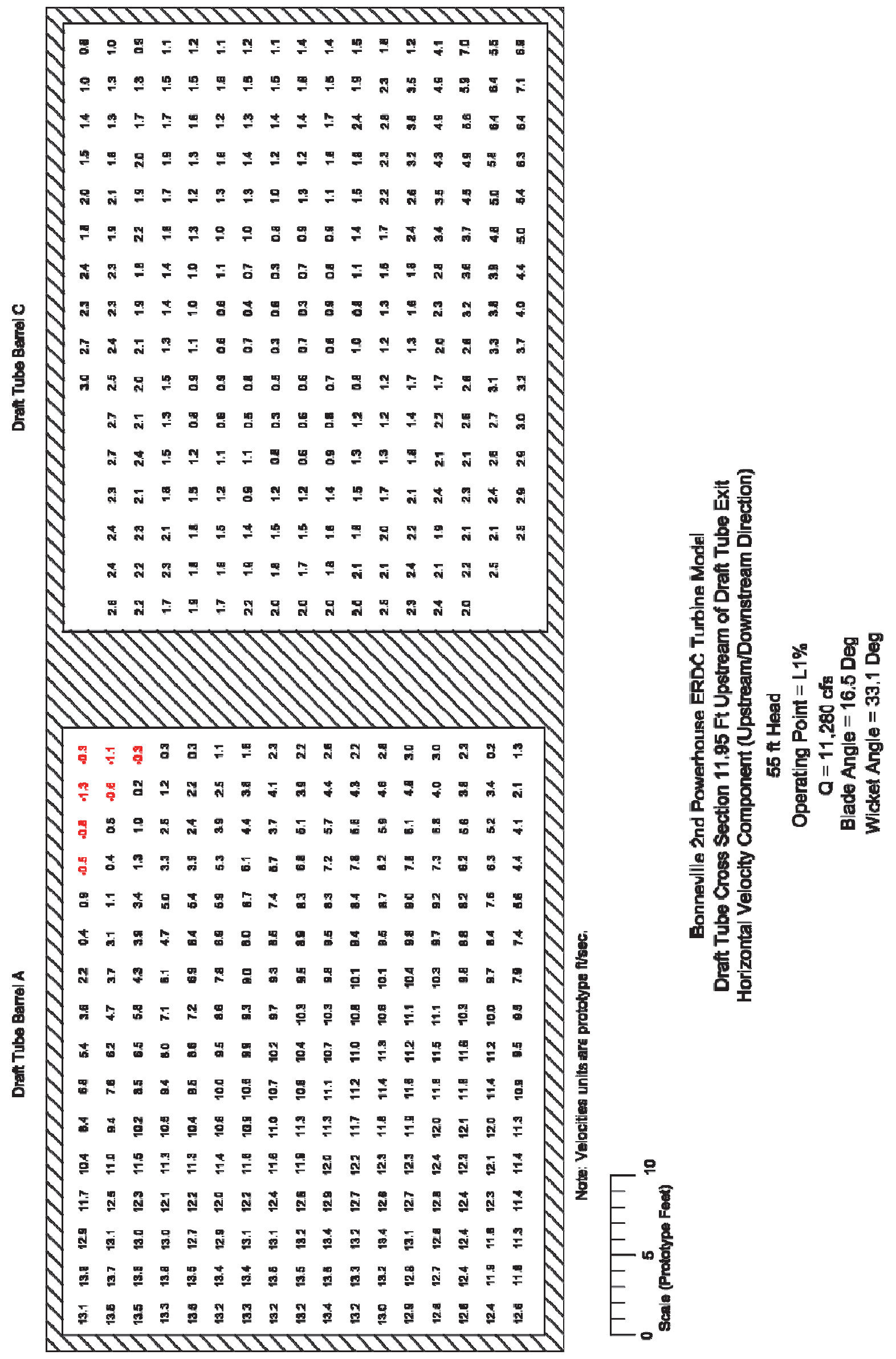




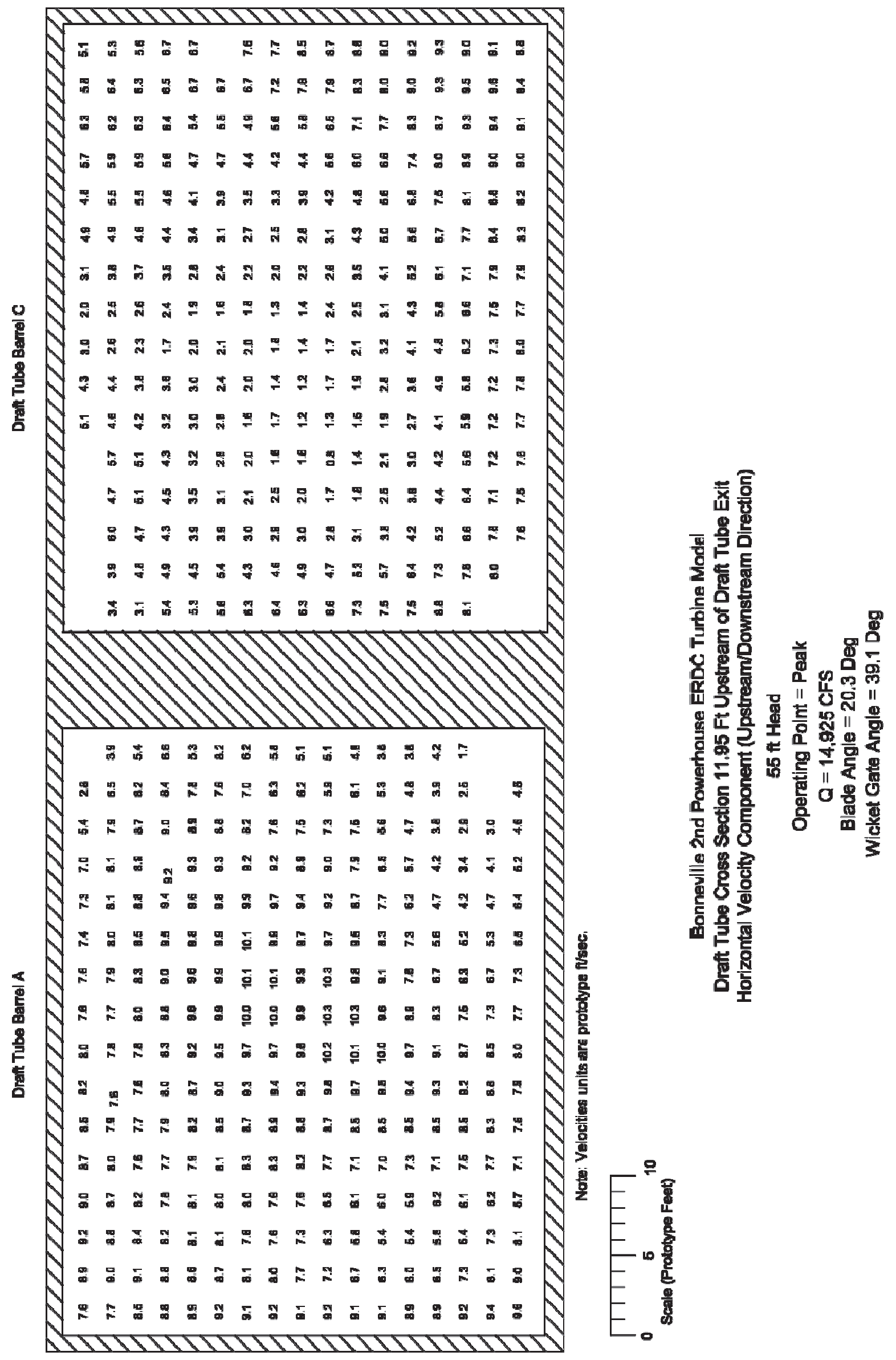




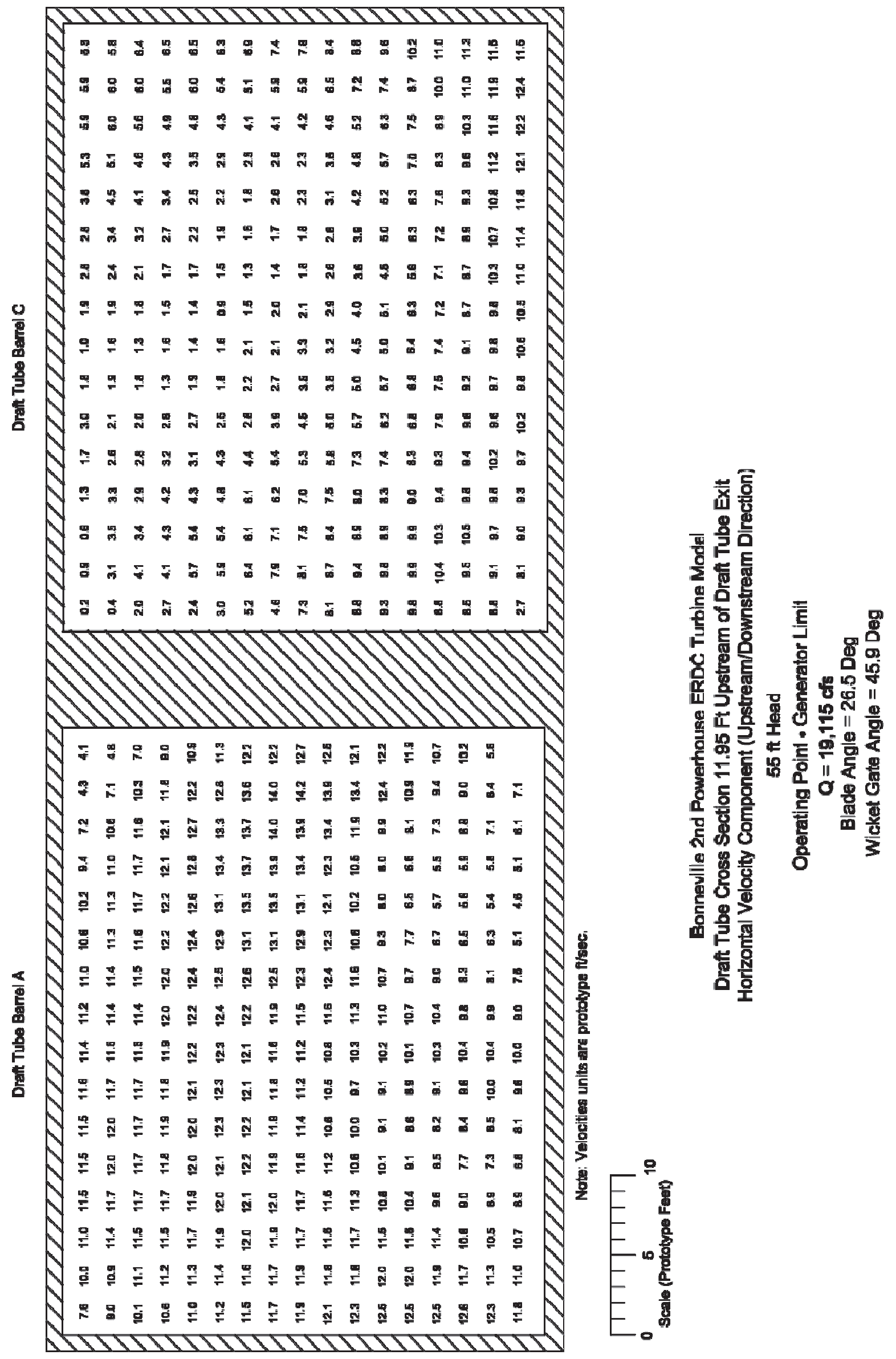


Bonneville 2nd Powerhouse

ERDC Turbine Model

Draft Tube Investigation

Based on LDV Measurements

$55 \mathrm{ft} \mathrm{Head}$

Downstream Section Barrel A

\begin{tabular}{|c|c|c|c|c|c|c|c|c|c|c|}
\hline Screens & $\begin{array}{c}\text { Blade } \\
\text { Angle, deg }\end{array}$ & Discharge, cfs & $\begin{array}{l}\text { Average Hor Vel } \\
\text { Comp, } \mathrm{ft} / \mathrm{sec}\end{array}$ & $\begin{array}{l}\text { STD Dev of all Hor } \\
\text { Vel Comp, ft/sec }\end{array}$ & $\begin{array}{c}\text { Average of STD of } \\
\text { Hor Vel } \\
\text { Measurements, } \\
\mathrm{ft} / \mathrm{sec}\end{array}$ & $\begin{array}{c}\text { STD dev of all Hor vel } \\
\text { Measurements/Ave vel, \% }\end{array}$ & $\begin{array}{l}\text { Ave STD dev of Hor Vel } \\
\text { Measurement/Ave Vel \% }\end{array}$ & $\begin{array}{l}\text { Max Hor Measured } \\
\text { Velocity, } \mathrm{ft} / \mathrm{sec}\end{array}$ & $\begin{array}{l}\text { Min Hor Measured } \\
\text { Velocity, } \mathrm{ft} / \mathrm{sec}\end{array}$ & $\begin{array}{l}\text { \% Barre } \\
\text { Flow }\end{array}$ \\
\hline installed & 16.5 & 11,280 & 8.6 & 4.1 & 2.4 & 47.5 & 27.6 & 13.8 & -1.3 & 81.1 \\
\hline installed & 20.3 & 14,295 & 7.8 & 1.6 & 1.6 & 21.1 & 21.1 & 10.3 & 2.8 & 61.6 \\
\hline installed & 26.5 & 19,120 & 10.8 & 2.1 & 1.9 & 19.2 & 17.2 & 14.2 & 4.1 & 65.5 \\
\hline
\end{tabular}

Bonneville 2nd Powerhouse

ERDC Turbine Model

Draft Tube Investigation

Based on LDV Measurements

$55 \mathrm{ft} \mathrm{Head}$

Downstream Section Barrel C

\begin{tabular}{|c|c|c|c|c|c|c|c|c|c|c|}
\hline Screens & $\begin{array}{c}\text { Blade } \\
\text { Angle, deg }\end{array}$ & Discharge, cfs & $\begin{array}{c}\text { Average Hor Vel } \\
\text { Comp, } \mathrm{ft} / \mathrm{sec}\end{array}$ & $\begin{array}{c}\text { STD Dev of all Hor } \\
\text { Vel Comp, } \mathrm{ft} / \mathrm{sec}\end{array}$ & $\begin{array}{c}\text { Average of STD of } \\
\text { Hor vel } \\
\text { Measurements, } \\
\mathrm{ft} / \mathrm{sec}\end{array}$ & $\begin{array}{c}\text { STD dev of all Hor vel } \\
\text { Measurements/Ave vel,\% }\end{array}$ & $\begin{array}{l}\text { Ave STD dev of Hor Vel } \\
\text { Measurement/Ave Vel\% }\end{array}$ & $\begin{array}{c}\text { Max Hor Measured } \\
\text { Velocity, } \mathrm{ft} / \mathrm{sec}\end{array}$ & $\begin{array}{l}\text { Min Hor Measured } \\
\text { Velocity, } \mathrm{ft} / \mathrm{sec}\end{array}$ & $\begin{array}{c}\text { \% Barrel } \\
\text { Flow }\end{array}$ \\
\hline installed & 16.5 & 11,280 & 2.0 & 1.3 & 1.5 & 63.9 & 72.4 & 7.1 & 0.3 & 18.9 \\
\hline installed & 20.3 & 14,295 & 5.0 & 2.3 & 2.3 & 46.0 & 46.3 & 9.6 & 0.8 & 38.4 \\
\hline installed & 26.5 & 19,120 & 5.8 & 3.1 & 2.8 & 53.5 & 48.7 & 12.4 & 0.2 & 34.5 \\
\hline
\end{tabular}




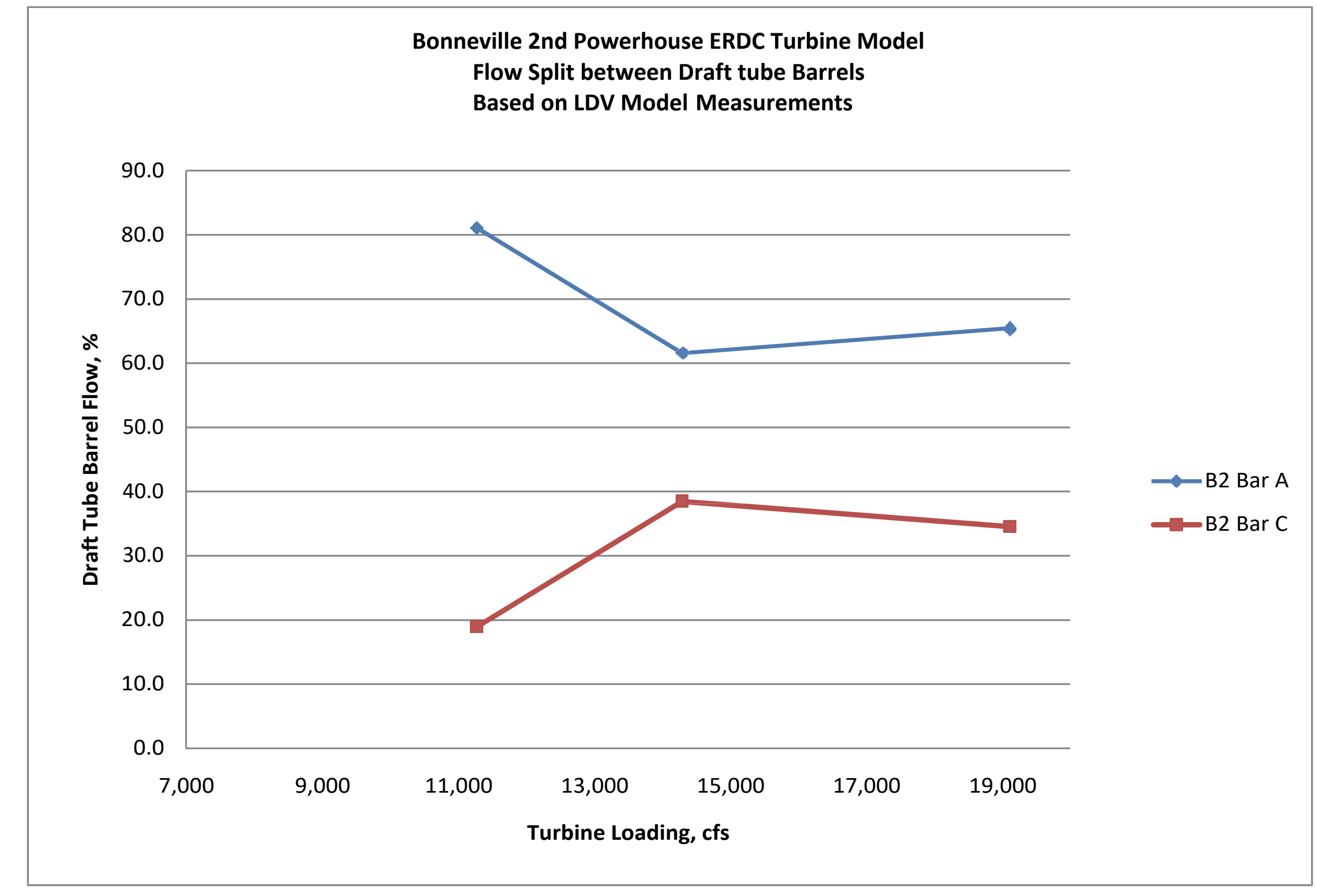




\section{Bonneville 2nd Powerhouse ERDC Turbine Model Measure of Draft tube Uniformity \\ STD of Hor Vels/Ave Vel \\ Based on LDV Model Measurements}

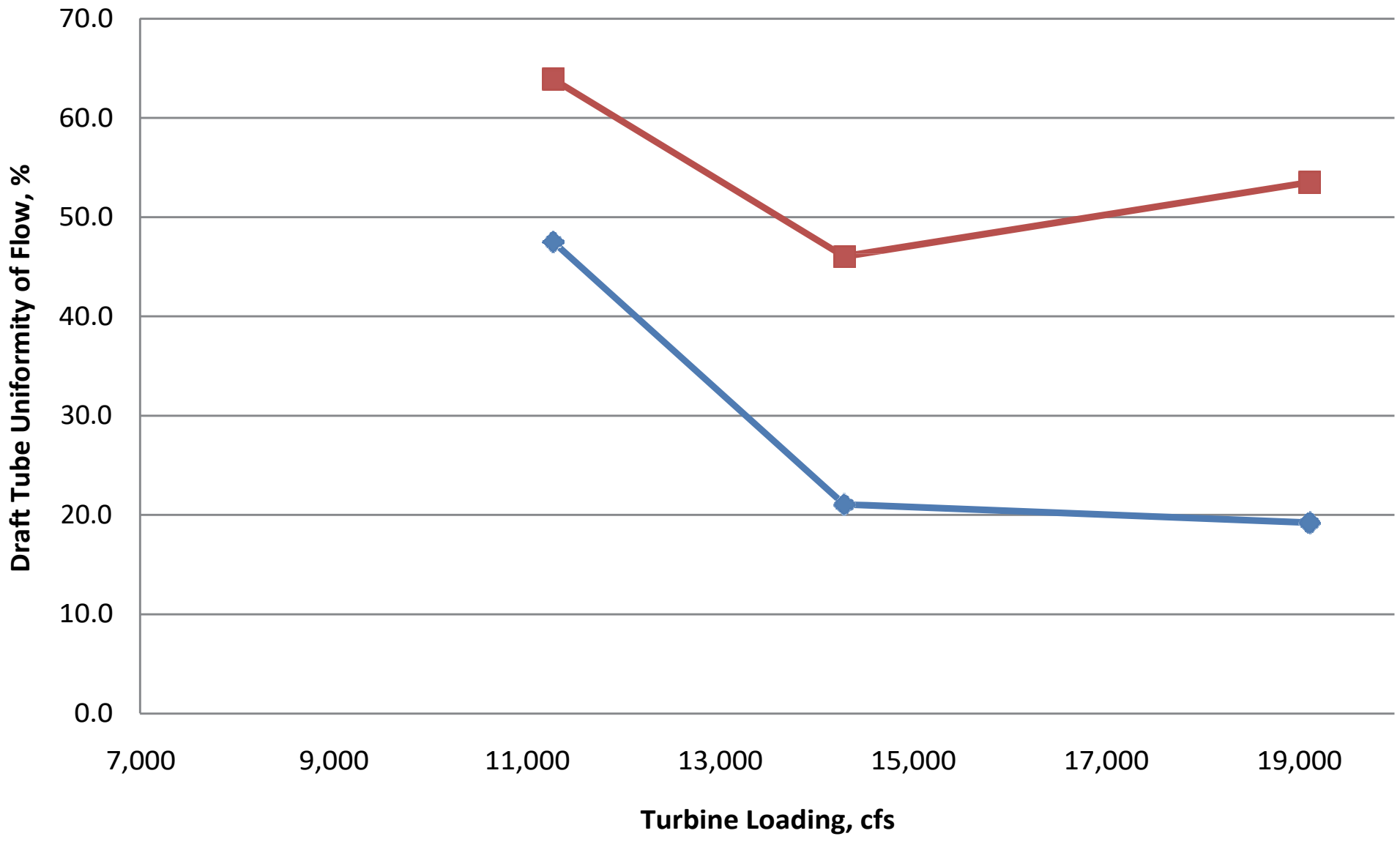

- B2 Bar A

-B2 Bar C 


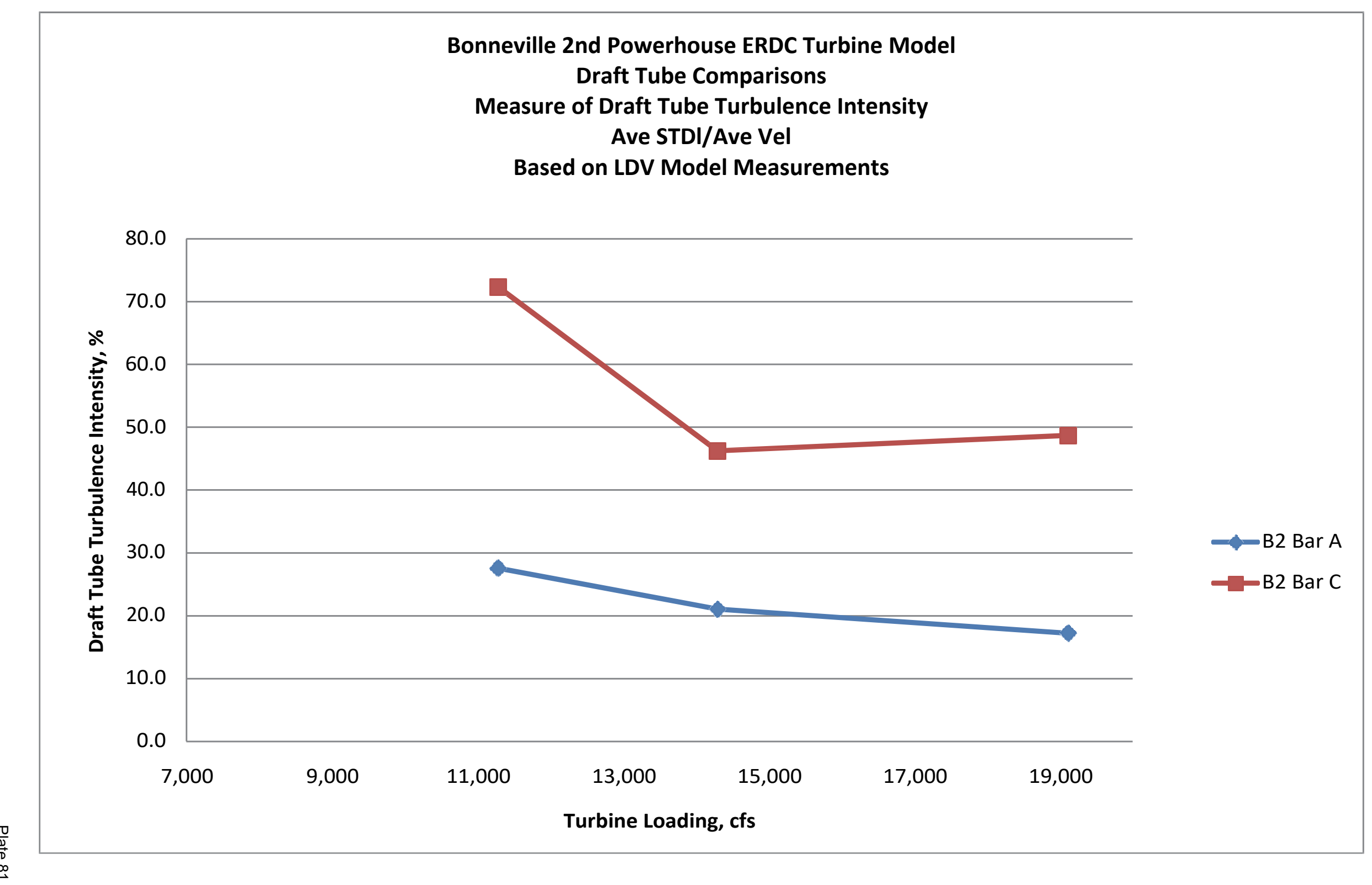


Bonneville 2nd Powerhouse ERDC Turbine Model

Bead Egress Data

$55 \mathrm{ft}$ Head

Screens installed

\begin{tabular}{|c|c|c|c|c|c|c|c|c|}
\hline Discharge, cfs & $\begin{array}{l}\text { Intake Bay } \\
\text { Release }\end{array}$ & $\begin{array}{c}\text { Average Travel } \\
\text { Time, sec }\end{array}$ & $\begin{array}{l}\text { Average Minimum } \\
\text { Depth, } \mathrm{ft}\end{array}$ & $\begin{array}{c}\text { Average Distance } \\
\text { to Minumum } \\
\text { Depth, } \mathrm{ft}\end{array}$ & $\begin{array}{c}\text { Percent Beads } \\
\text { Passing Near } \\
\text { Surface }\end{array}$ & $\begin{array}{l}\text { Percent Beads } \\
\text { Passing Between } \\
\text { Surface and } 5 \mathrm{ft}\end{array}$ & $\begin{array}{c}\text { Percent } \\
\text { beads } \\
\text { Entrained } \\
\text { into Backroll }\end{array}$ & $\begin{array}{l}\text { Number } \\
\text { of Beads }\end{array}$ \\
\hline 11278 & All Combined & 119.3 & 19.3 & 140.1 & 24.6 & 34.0 & 19.4 & 810 \\
\hline 14924 & All Combined & N/A & N/A & N/A & N/A & N/A & N/A & N/A \\
\hline 19115 & All Combined & 59.7 & 24.3 & 179.5 & 17.8 & 19.5 & 3.7 & 810 \\
\hline
\end{tabular}




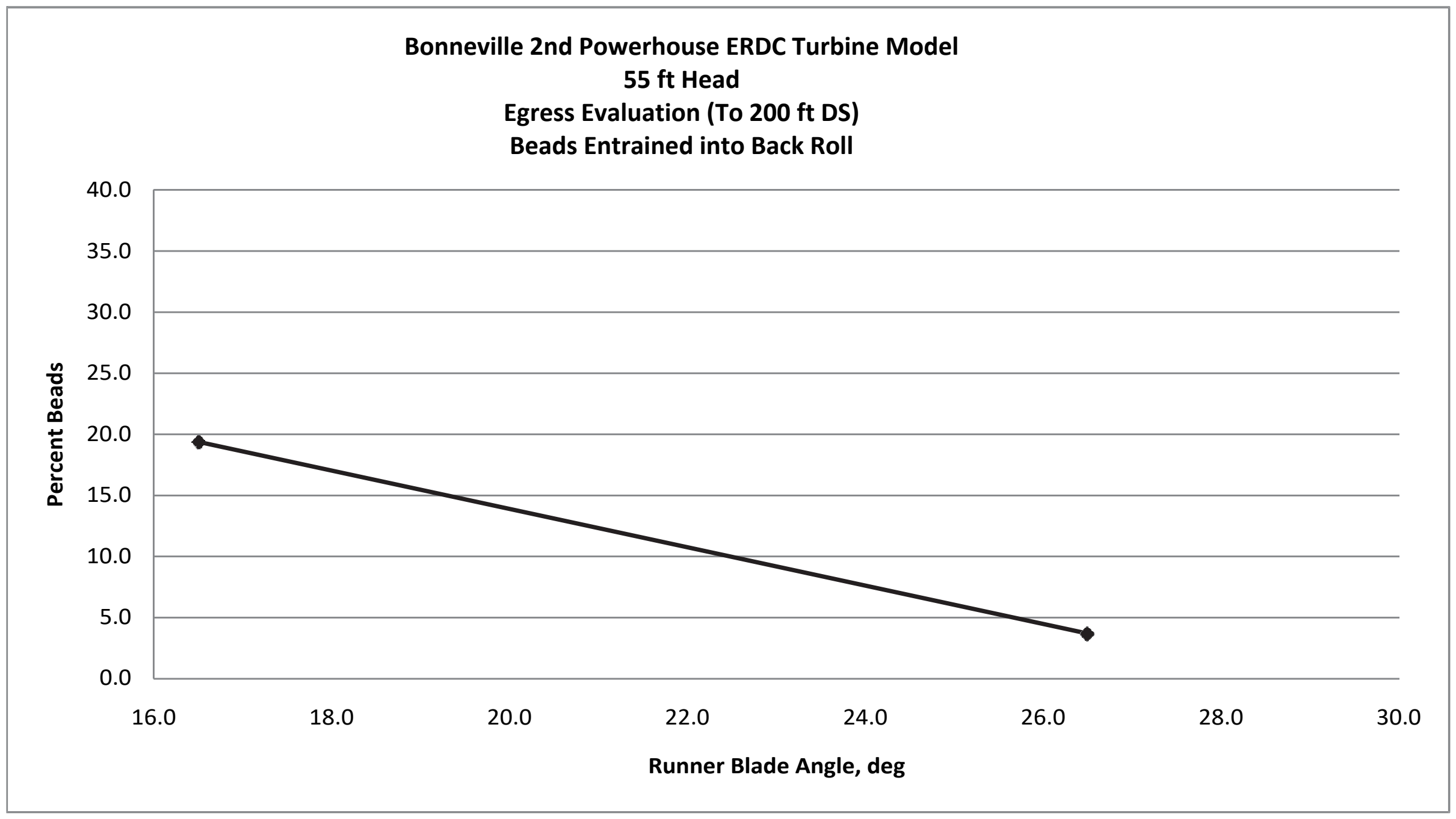




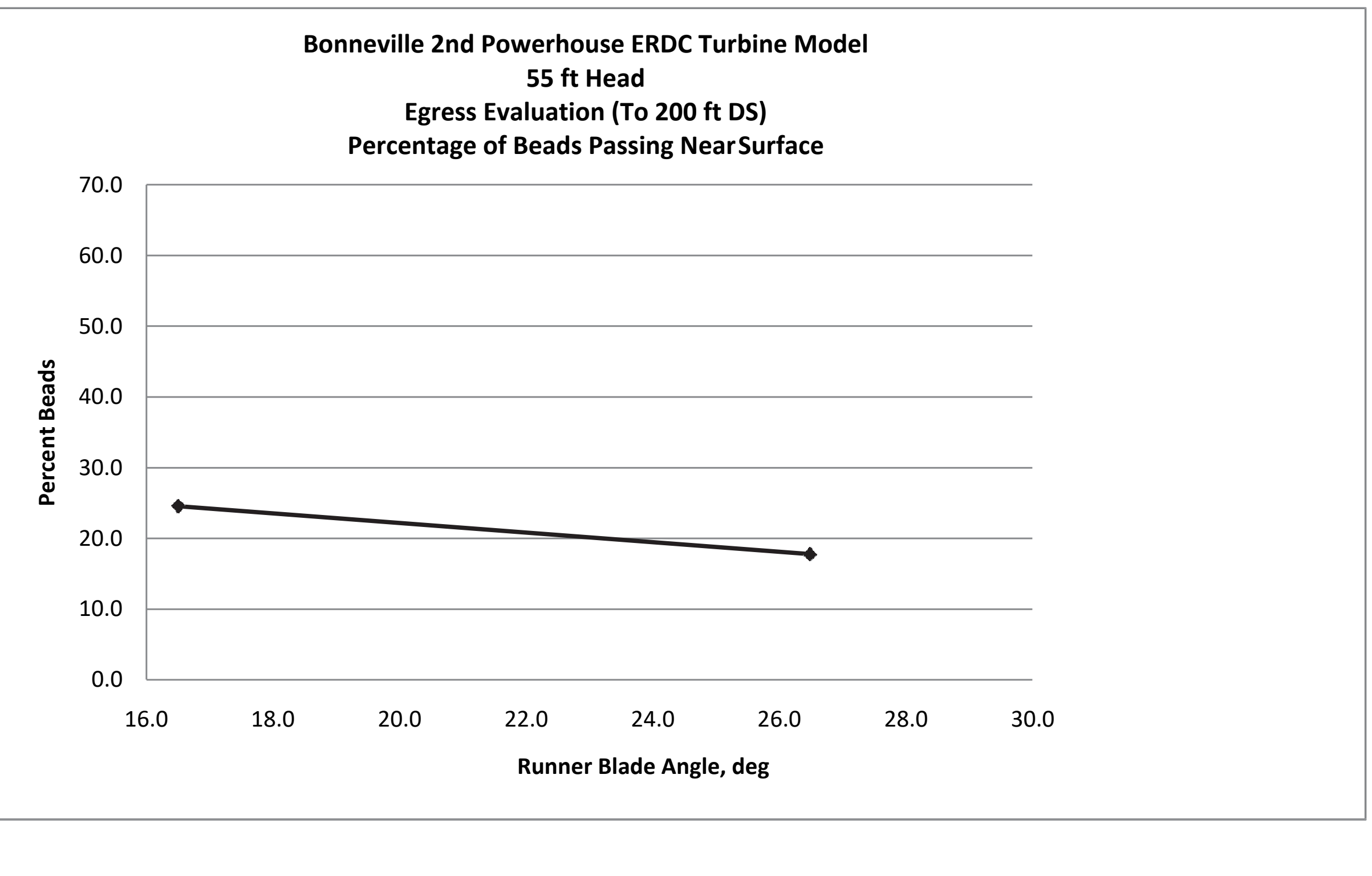




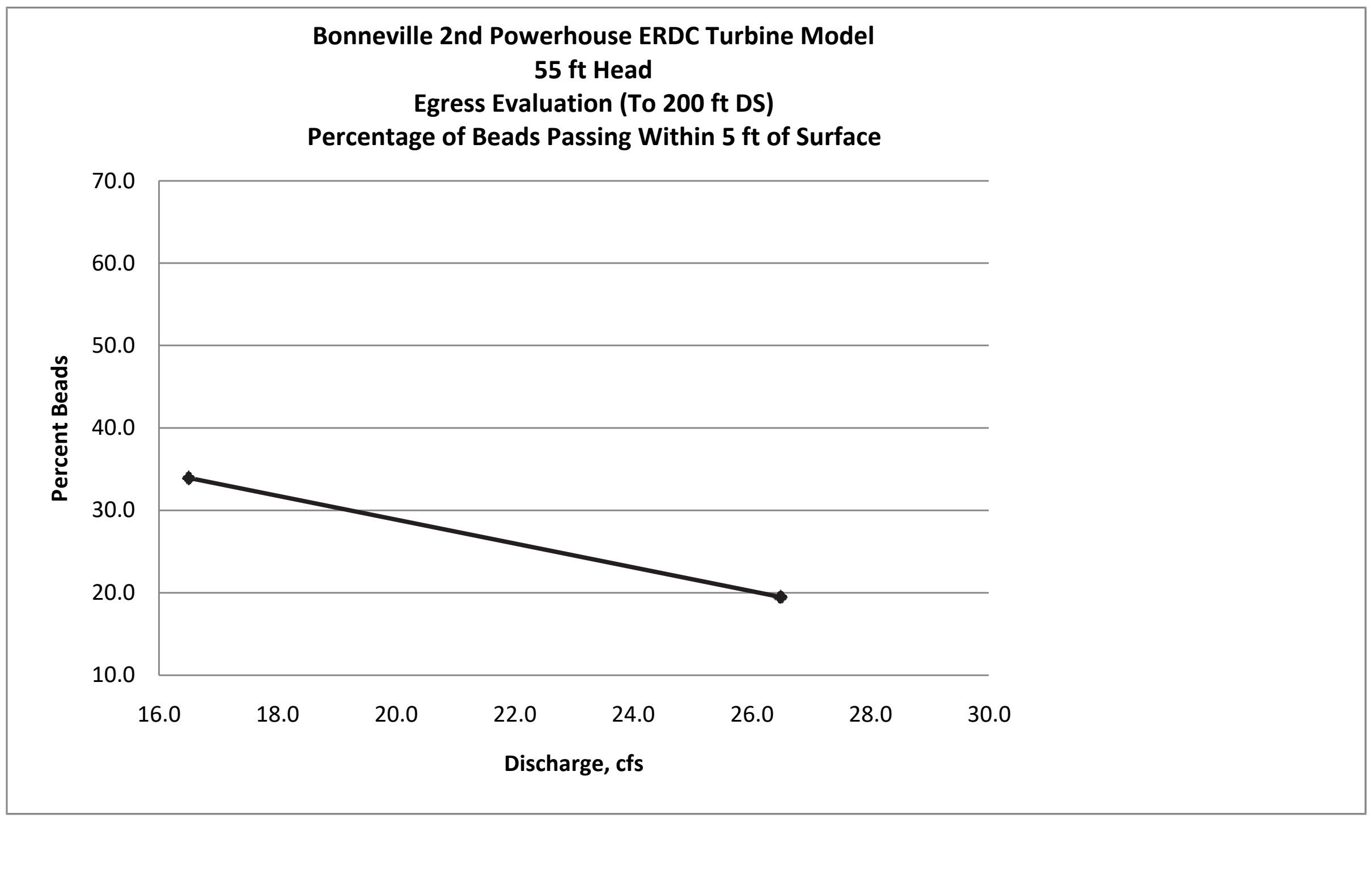




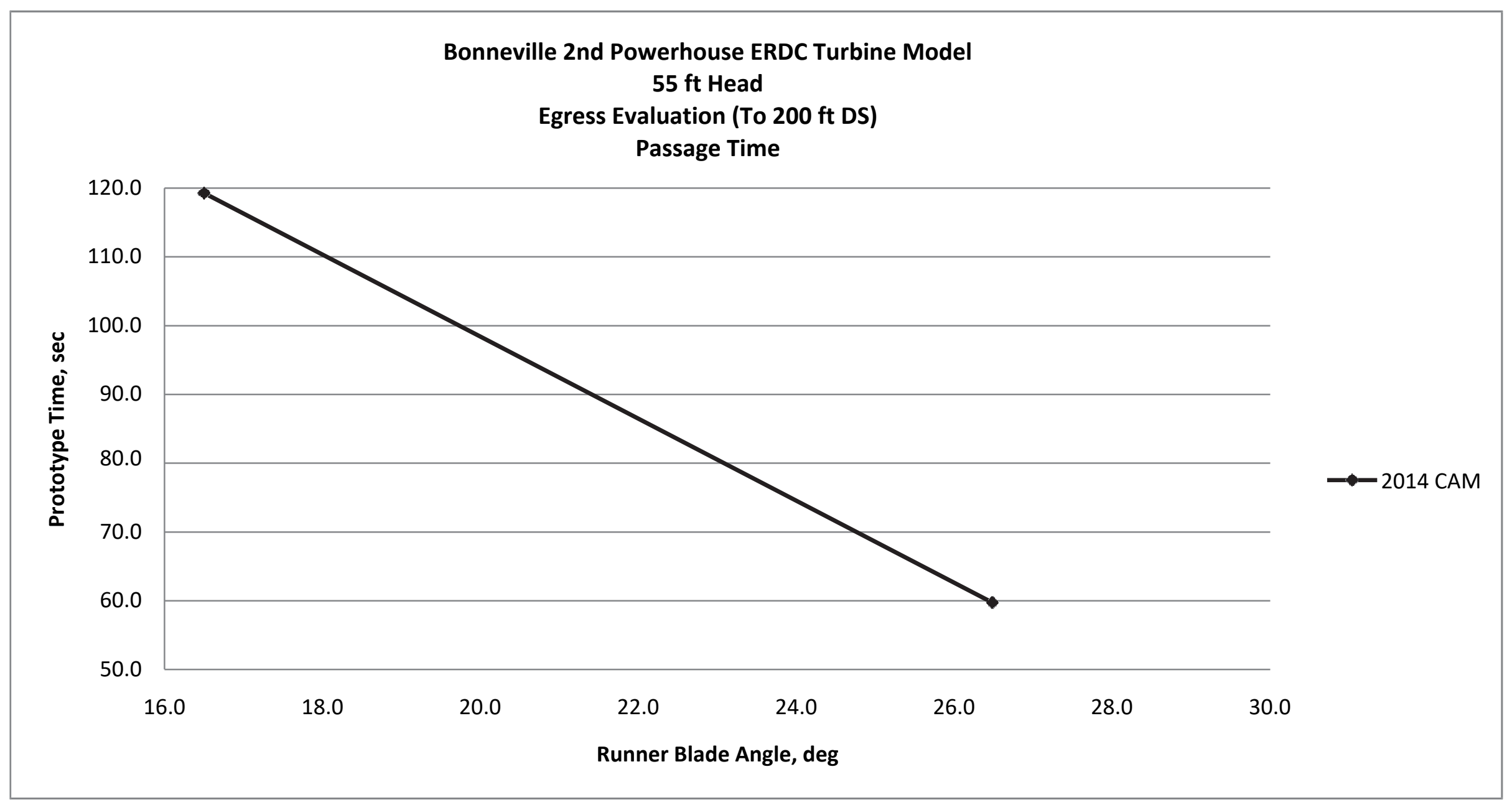




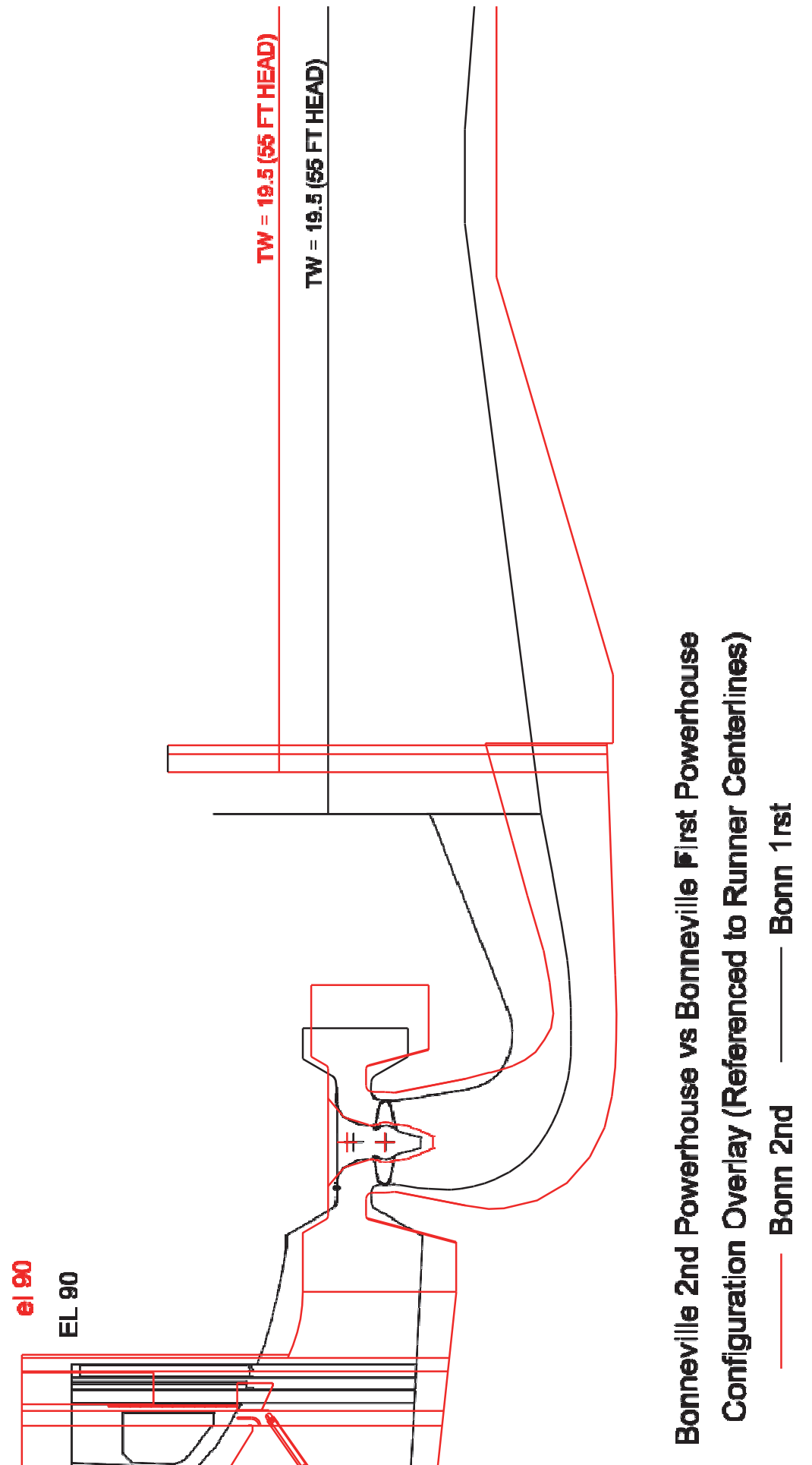

ำ 


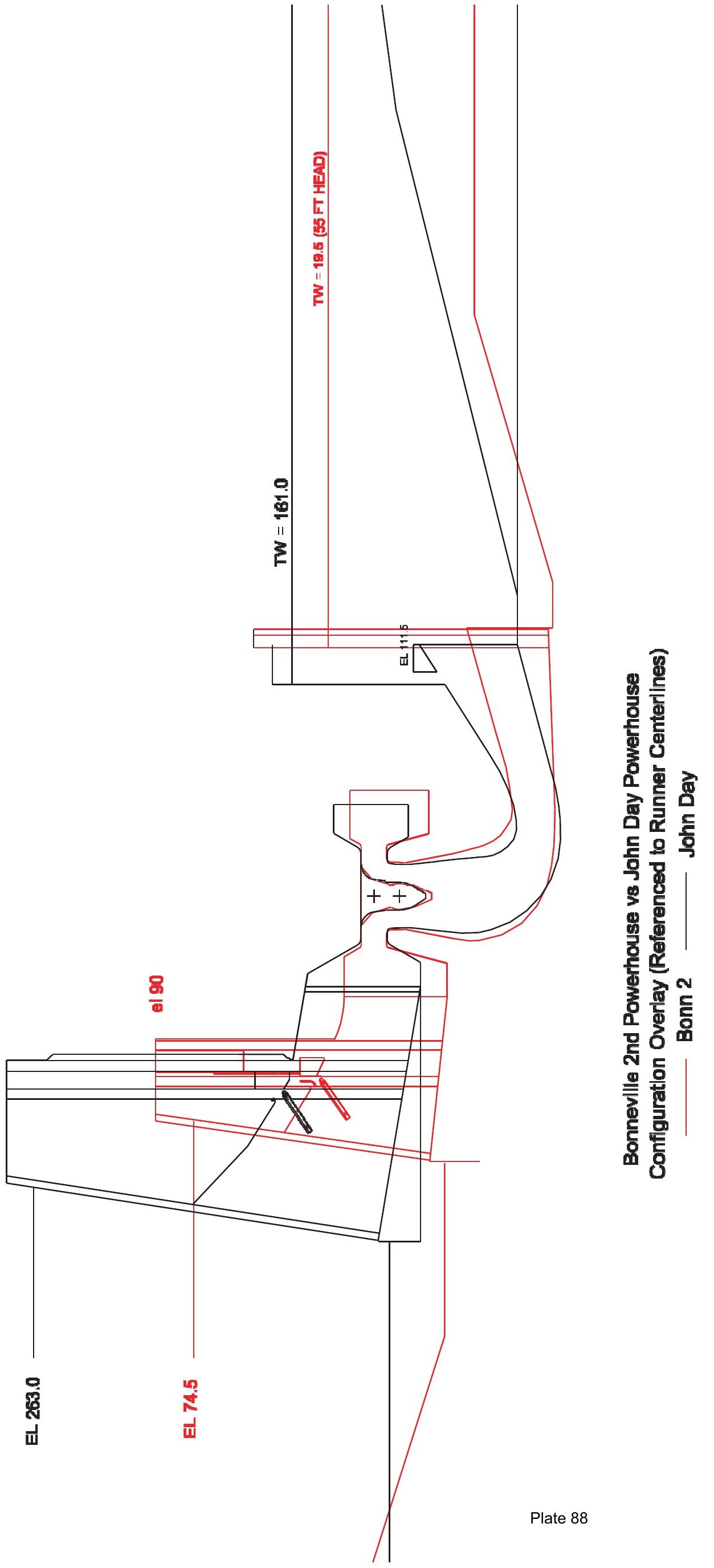




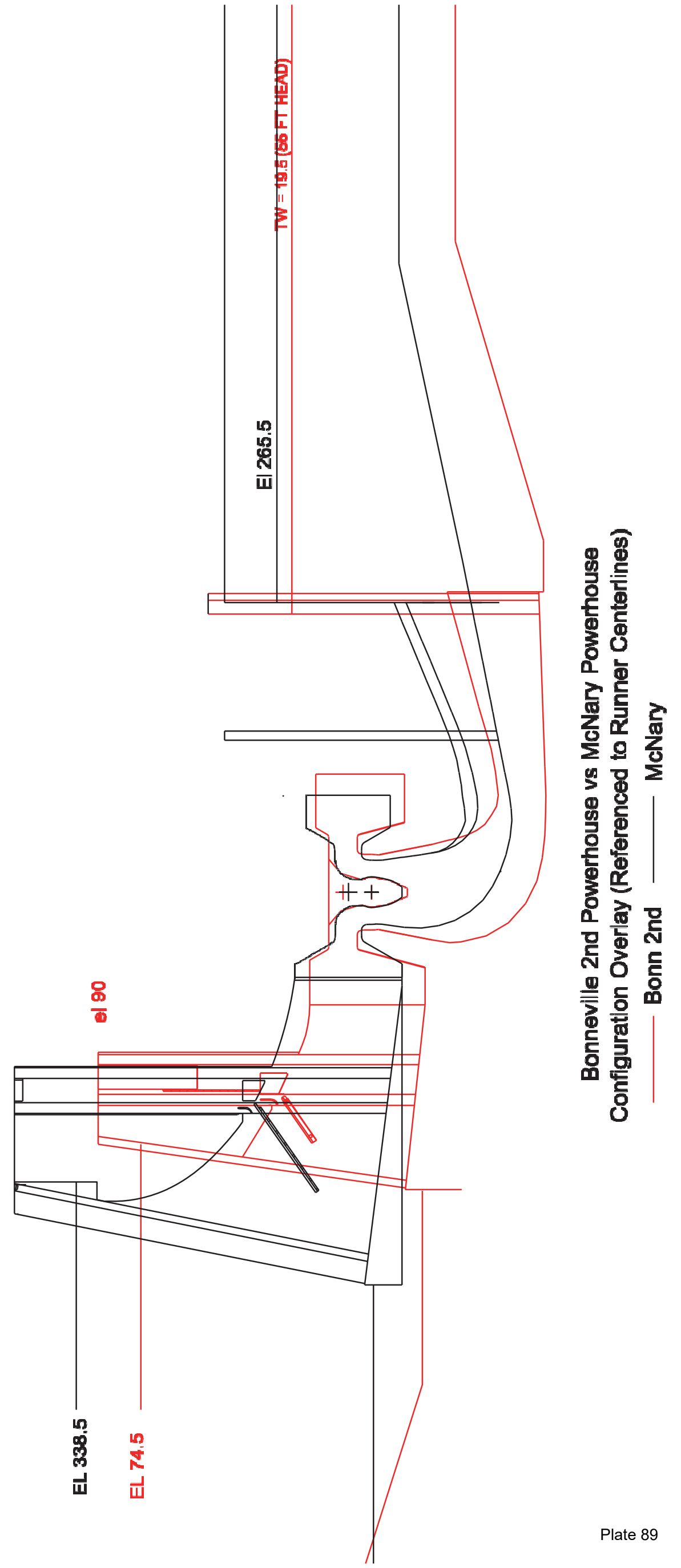




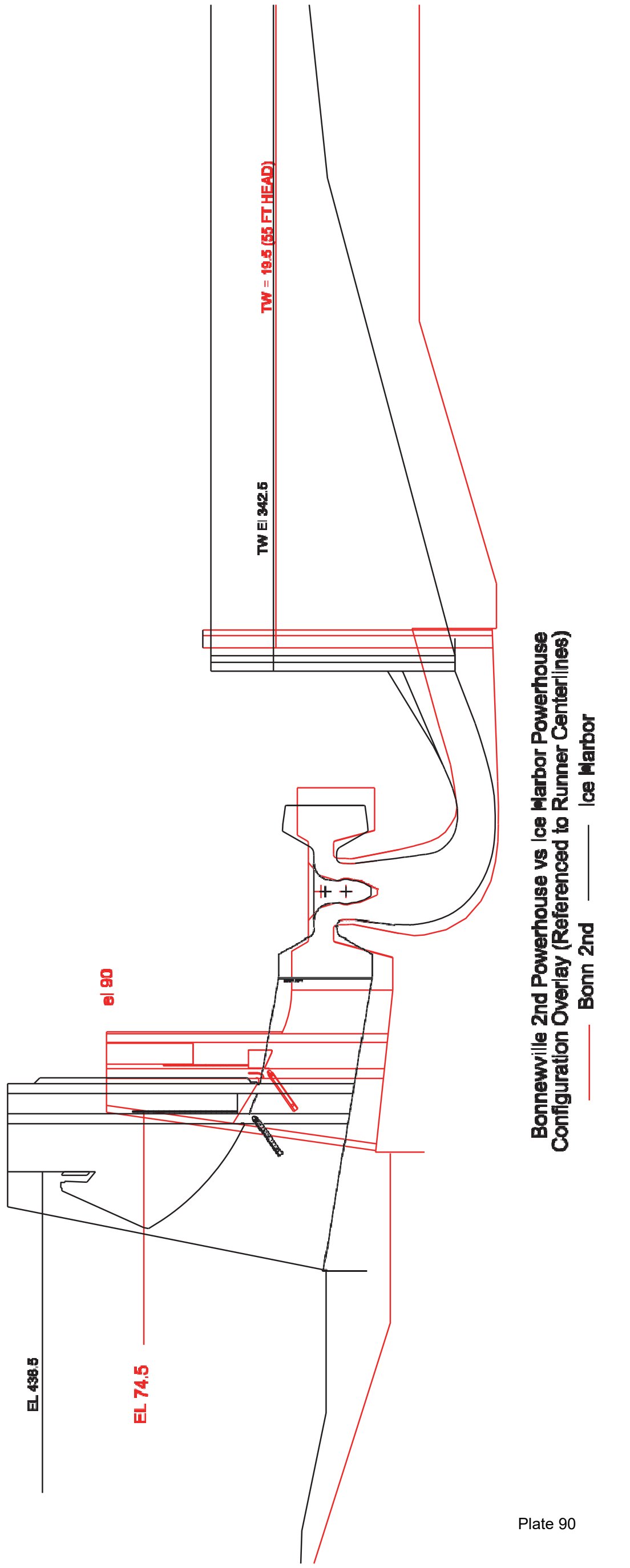




\begin{tabular}{|c|c|c|c|c|c|c|c|c|c|}
\hline Project & In Service & $\begin{array}{c}\text { Runner } \\
\text { Diameter, inches }\end{array}$ & $\begin{array}{l}\text { Prototype } \\
\text { Runner } \\
\text { Speed, rpm }\end{array}$ & $\begin{array}{c}\text { Number of } \\
\text { Runner Blades }\end{array}$ & $\begin{array}{c}\text { Number of } \\
\text { Wicket Gates }\end{array}$ & $\begin{array}{l}\text { Number of } \\
\text { Stay Vanes }\end{array}$ & Head Tested & Screen Type & $\begin{array}{c}\text { ERDC Model } \\
\text { Runner Speed, } \\
\text { RPM }\end{array}$ \\
\hline B1 & 1938 (MGR 2010) & 280 & 75 & 5 & 20 & 17 & 55 and 60 & None & 375 \\
\hline B2 & 1982 & 331.2 & 69.2 & 5 & 24 & 23 & 55 & $20 \mathrm{Ft} \mathrm{STS}$ & 346 \\
\hline McNary & 1957 & 280 & 85.7 & 6 & 20 & 19 & 73 & $40 \mathrm{Ft}$ ESBS & 428.5 \\
\hline John Day & 191 & 312 & 90 & 6 & 23 & 22 & 102 & $20 \mathrm{Ft} \mathrm{STS}$ & 450 \\
\hline Ice Harbor 1-3 & 1962 & 280 & 90 & 6 & 20 & 19 & 96 & $20 \mathrm{Ft} \mathrm{STS}$ & 450 \\
\hline Lower Granite 4-6 & 1978 & 312 & 90 & 6 & 20 & 19 & 100 to 105 & $40 \mathrm{Ft}$ ESBS & 450 \\
\hline
\end{tabular}

Positive attributes for B2:

Largest Runner Diameter - more flow area

Least number of blades - 5

Lowest Runner speed

Only runner with cavitations fins

Leading edge of Stay Vane Shaped

Draft Tube Elbow Very Large (Oversized) 


\begin{tabular}{|c|c|c|c|c|c|c|c|c|c|c|c|}
\hline Project & Head Tested & Lower $1 \%$ Percent & $\begin{array}{c}\text { Axial Average Water } \\
\text { Velocity, } \mathrm{ft} / \mathrm{sec}\end{array}$ & $\begin{array}{c}\text { Upper } 1 \% \text { or } \\
\text { Gen Limit } \\
\text { Discharge, } \\
\text { cfs }\end{array}$ & $\begin{array}{c}\text { Axial Average } \\
\text { Water Velocity, } \\
\mathrm{ft} / \mathrm{sec}\end{array}$ & $\begin{array}{c}\text { Tangential } \\
\text { Blade Speed at } \\
\text { Blade Tip,ft } / \mathrm{sec}\end{array}$ & $\begin{array}{c}\text { Tangential } \\
\text { Blade Speed at } \\
\text { Blade Tip, } \\
\text { miles/hour }\end{array}$ & $\begin{array}{c}\text { Tangential } \\
\text { Blade Speed } \\
\text { at Mid Blade, } \\
\mathrm{ft} / \mathrm{sec} \\
\end{array}$ & $\begin{array}{c}\text { Tangential } \\
\text { Blade Speed } \\
\text { at Mid Blade, } \\
\text { miles } / \mathrm{hr}\end{array}$ & $\begin{array}{c}\text { Tangential } \\
\text { Blade Speed } \\
\text { at Hub, } \mathrm{ft} / \mathrm{sec}\end{array}$ & $\begin{array}{c}\text { Tangential } \\
\text { Blade Speed at } \\
\text { Hub, miles } / \mathrm{hr}\end{array}$ \\
\hline B1 & 55 and 60 & 7,266 & 21.0 & 9,800 & 28.3 & 91.5 & 62.4 & 65.7 & 44.8 & 39.9 & 27.2 \\
\hline B2 & 55 & 11,280 & 22.4 & 19,700 & 39.1 & 99.9 & 68.1 & 69.8 & 47.6 & 39.7 & 27.1 \\
\hline McNary & 73 & 7,699 & 23.5 & 12,190 & 37.2 & 104.6 & 71.3 & 77.5 & 52.8 & 50.4 & 34.4 \\
\hline John Day & 102 & 11,800 & 27.7 & 20,700 & 48.6 & 122.4 & 83.4 & 88.3 & 60.2 & 54.2 & 37.0 \\
\hline Ice Harbor 1-3 & 96 & 8,800 & 25.5 & 13,352 & 42.6 & 109.8 & 74.9 & 79.0 & 53.9 & 48.2 & 32.8 \\
\hline Lower Granite 4-6 & 100 and 105 & 13,500 & 31.4 & 18,000 & 41.9 & 122.4 & 83.4 & 87.9 & 59.9 & 53.3 & 36.4 \\
\hline
\end{tabular}

Positive attributes for B2:

Second lowest blade tangential speed at mid blade and tip

Lowest blade tangential speed at hub

Low Project head

Broad operating range 
USACE Project Average Stay Vane entrance Velocities

\begin{tabular}{|c|c|c|c|c|c|}
\hline Project & Head Tested & Lower 1\% Percent & $\begin{array}{c}\text { Average Water } \\
\text { Velocity at Stay } \\
\text { Vane Leading Edge, } \\
\mathrm{ft} / \mathrm{sec}\end{array}$ & $\begin{array}{c}\text { Upper } 1 \% \text { or } \\
\text { Gen Limit } \\
\text { Discharge, } \\
\text { cfs }\end{array}$ & $\begin{array}{c}\text { Average Water } \\
\text { Velocity at Stay } \\
\text { Vane Leading Edge, } \\
\mathrm{ft} / \mathrm{sec}\end{array}$ \\
\hline B1 & 55 and 60 & 7,266 & 5.3 & 9,800 & 7.1 \\
\hline B2 & 55 & 11,280 & 8.7 & 19,700 & 15.2 \\
\hline McNary & 73 & 7,699 & 5.6 & 12,190 & 8.9 \\
\hline John Day & 102 & 11,800 & 7.3 & 20,700 & 12.8 \\
\hline Ice Harbor 1-3 & 96 & 8,800 & 6.4 & 13,352 & 9.8 \\
\hline Lower Granite 4-6 & 100 and 105 & 13,500 & 8.4 & 18,000 & 11.2 \\
\hline
\end{tabular}




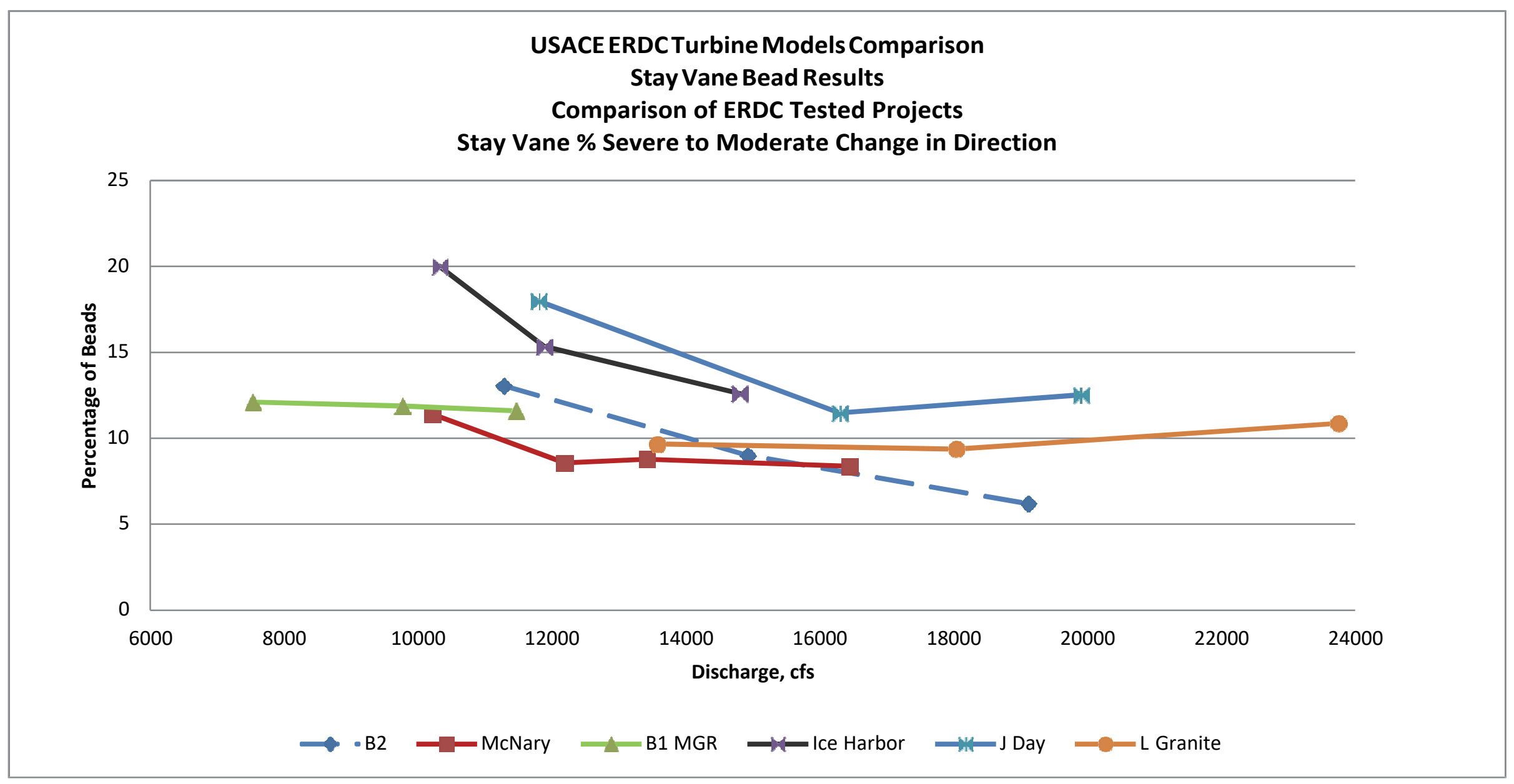




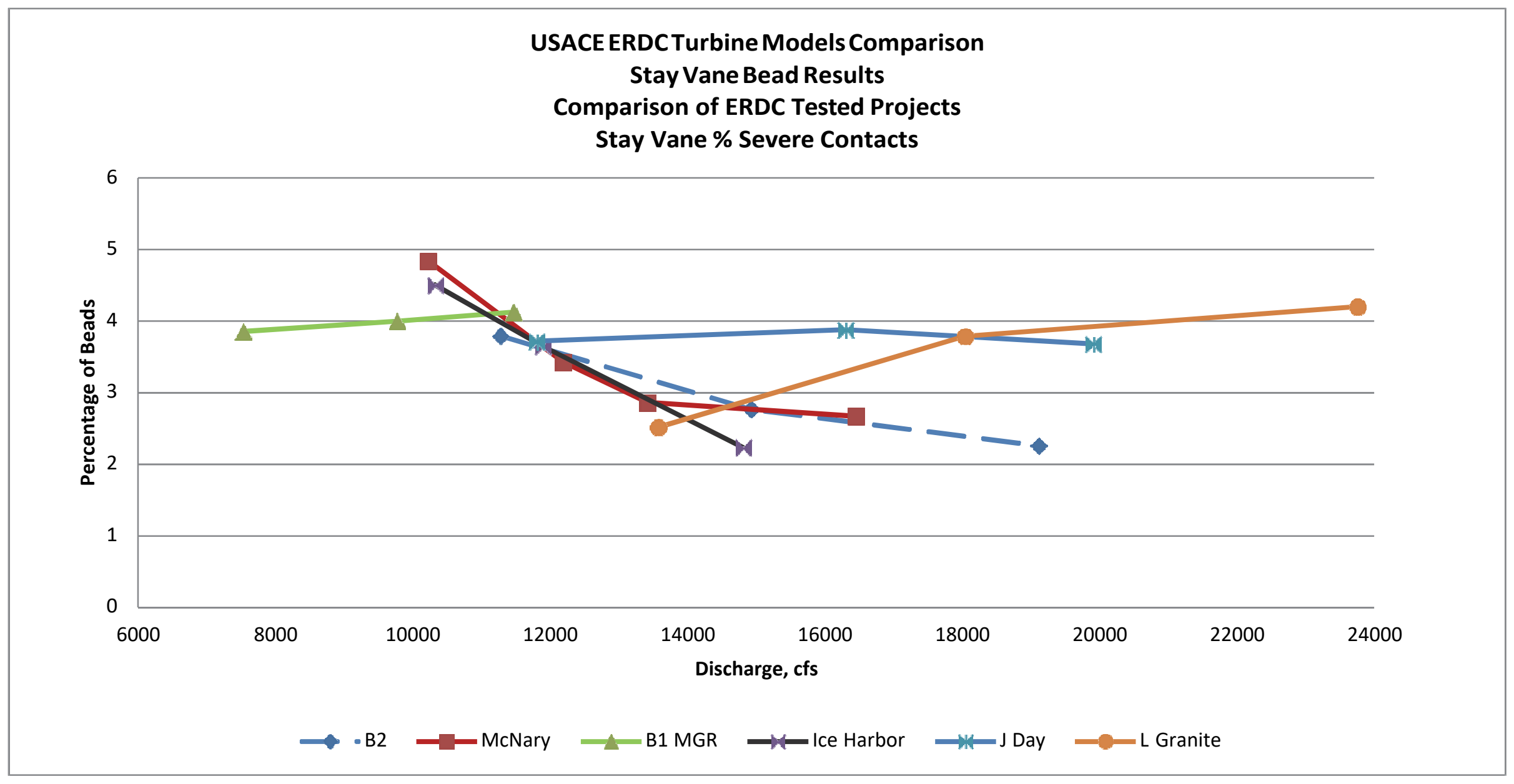




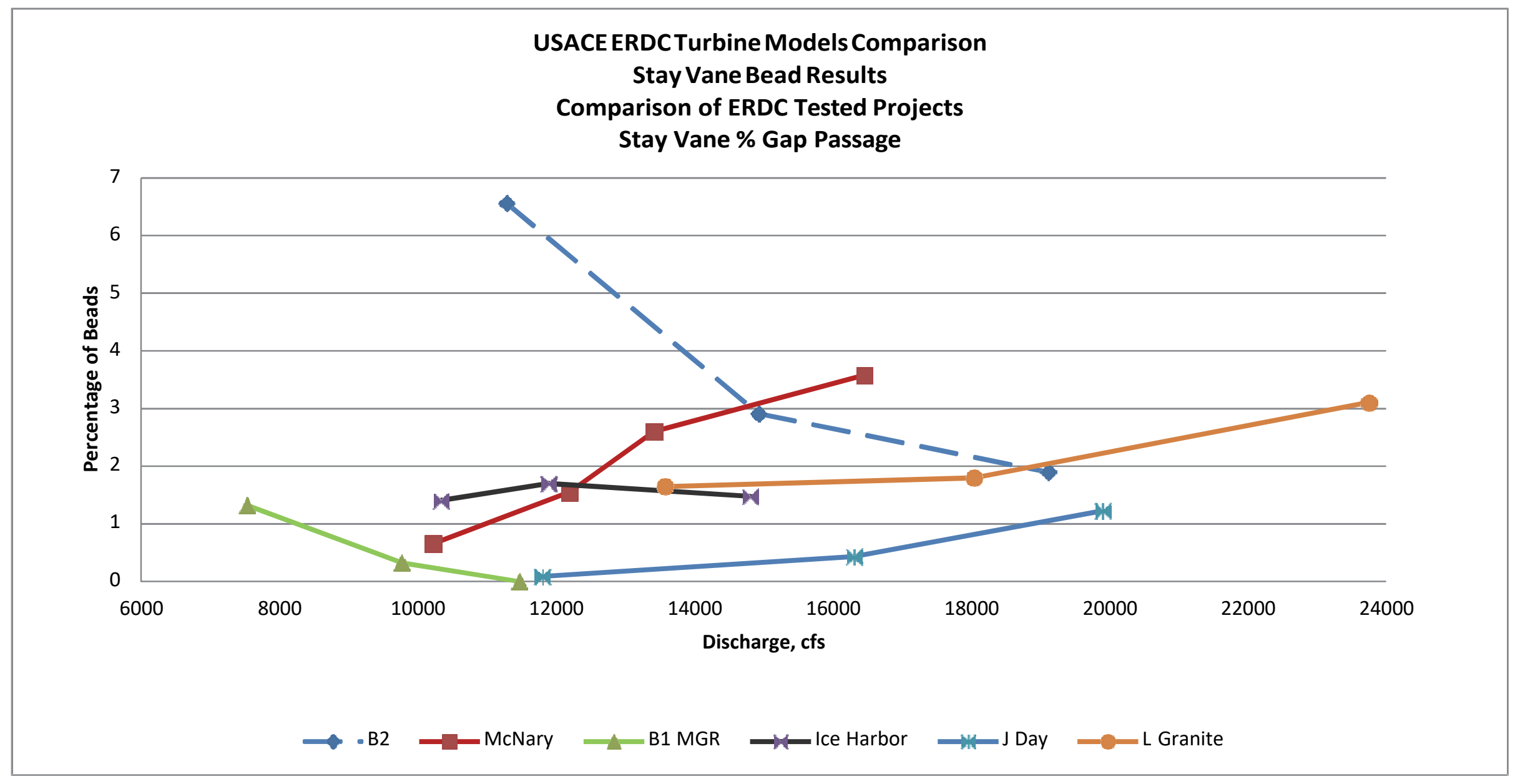




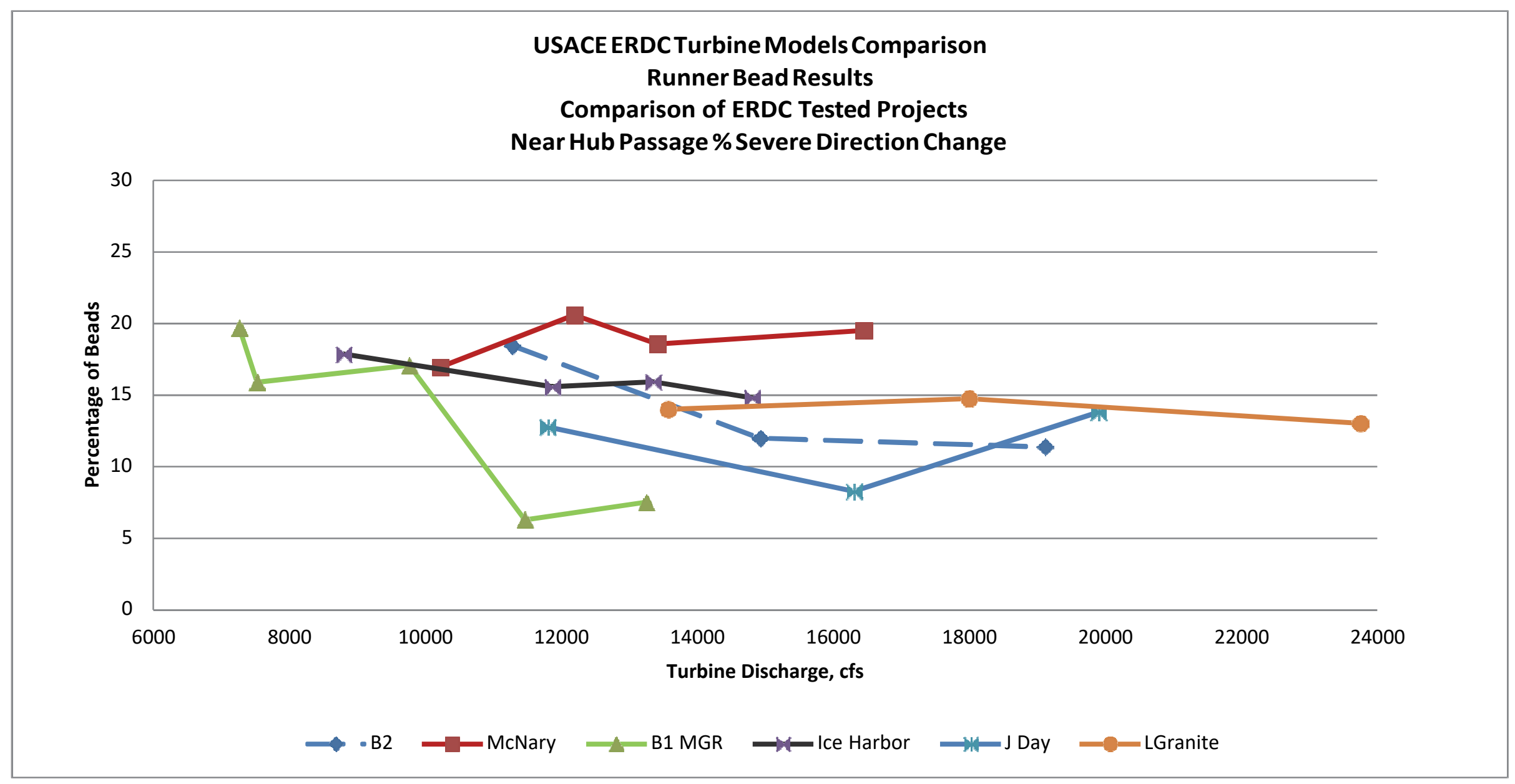




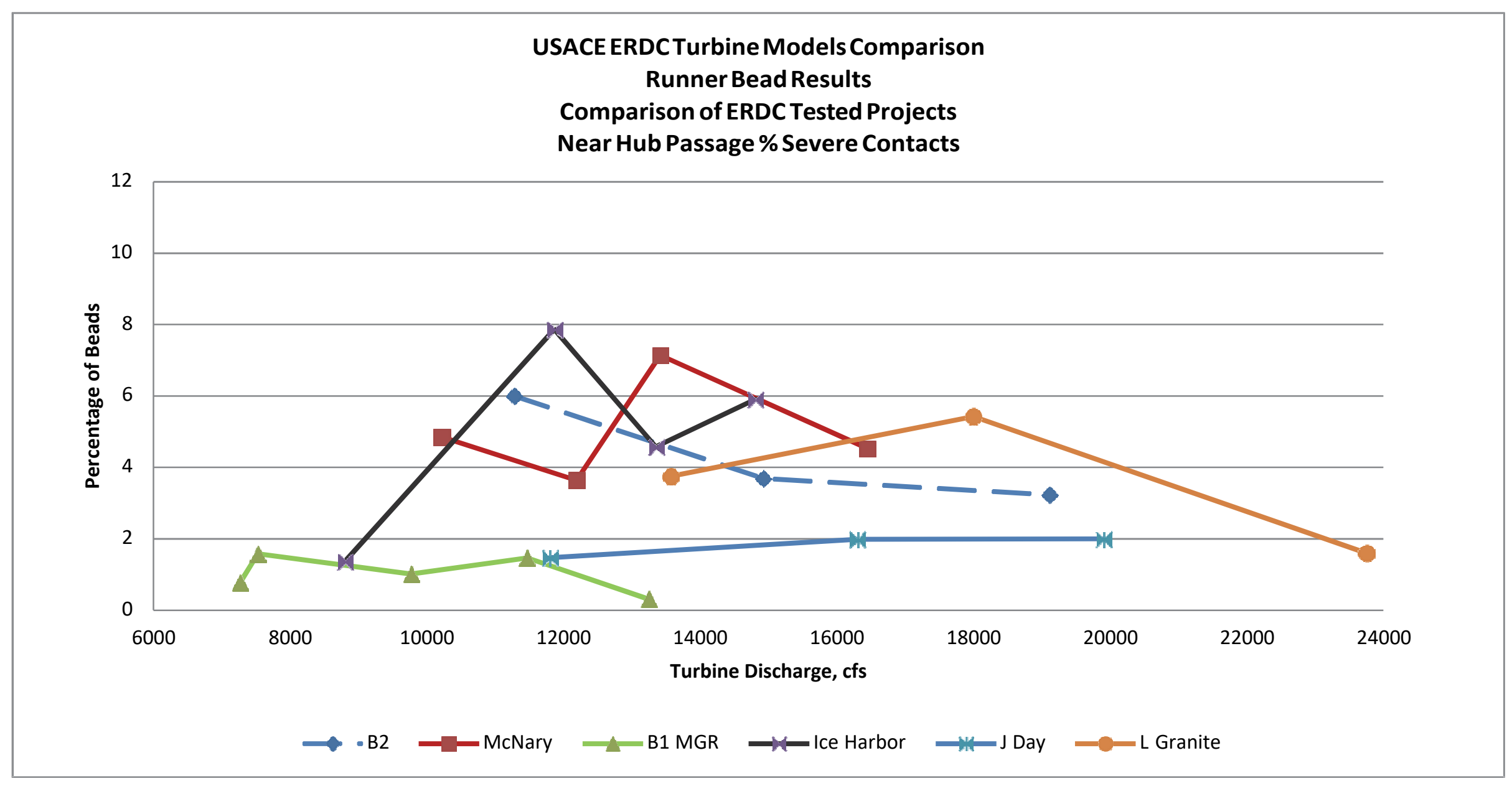




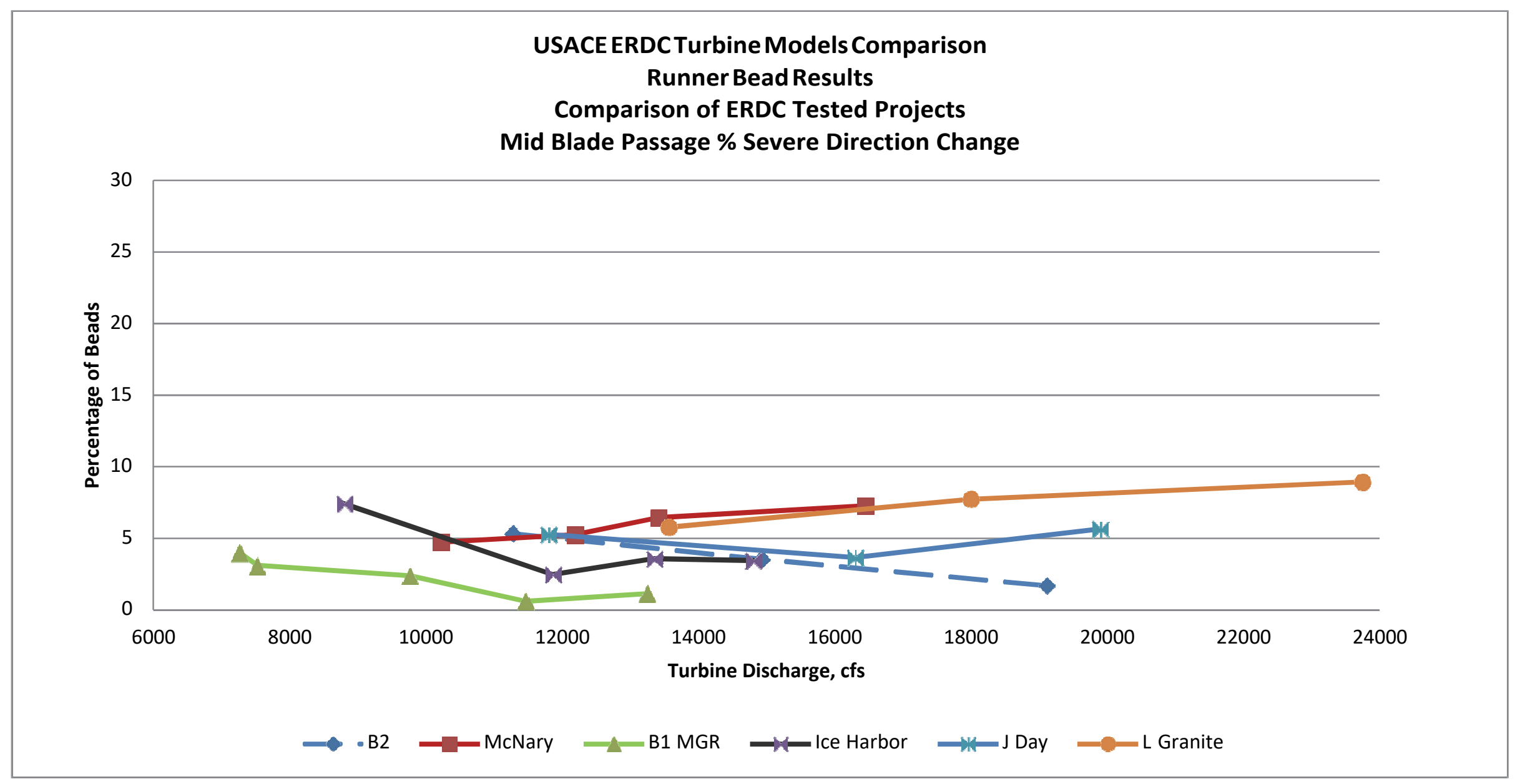




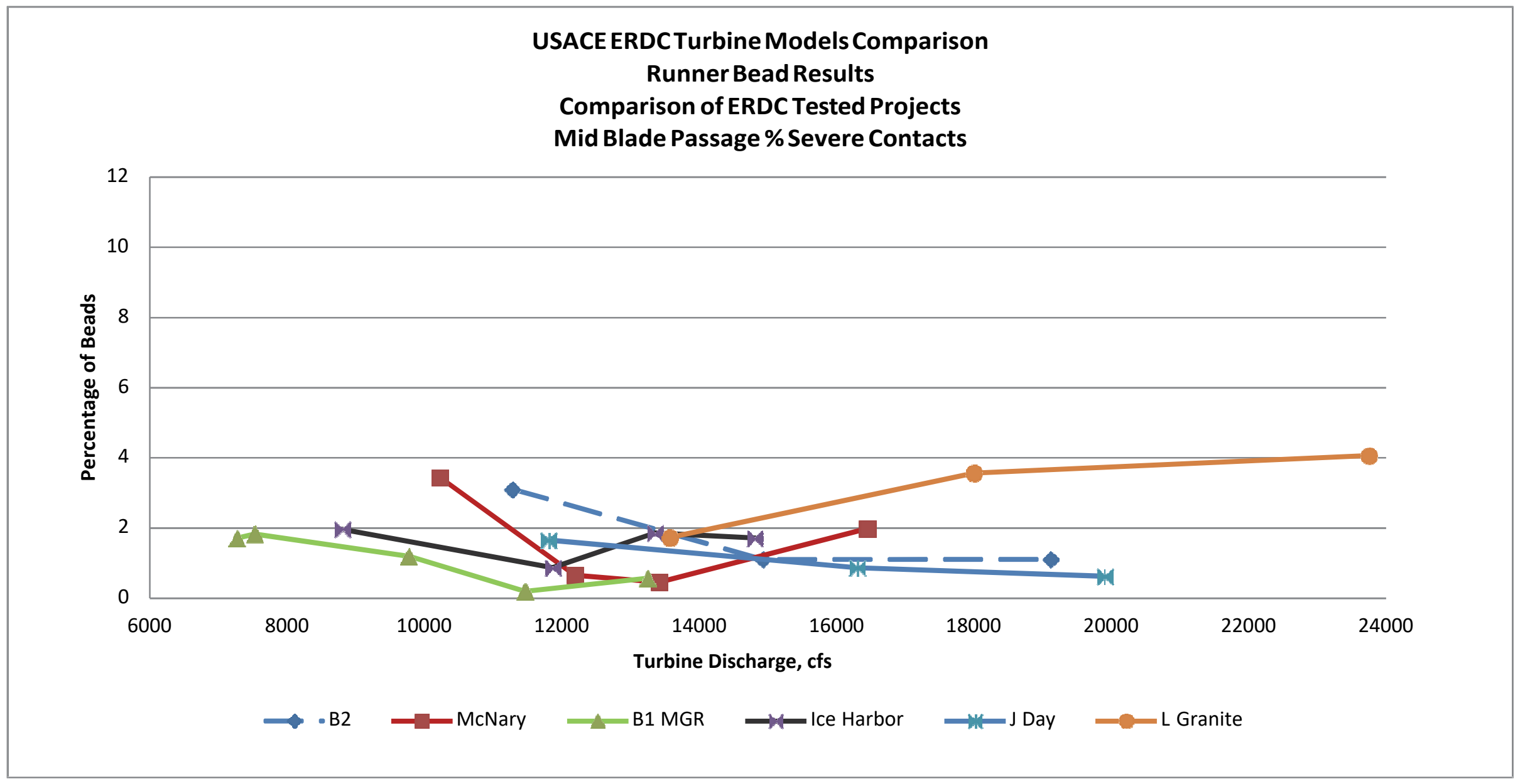




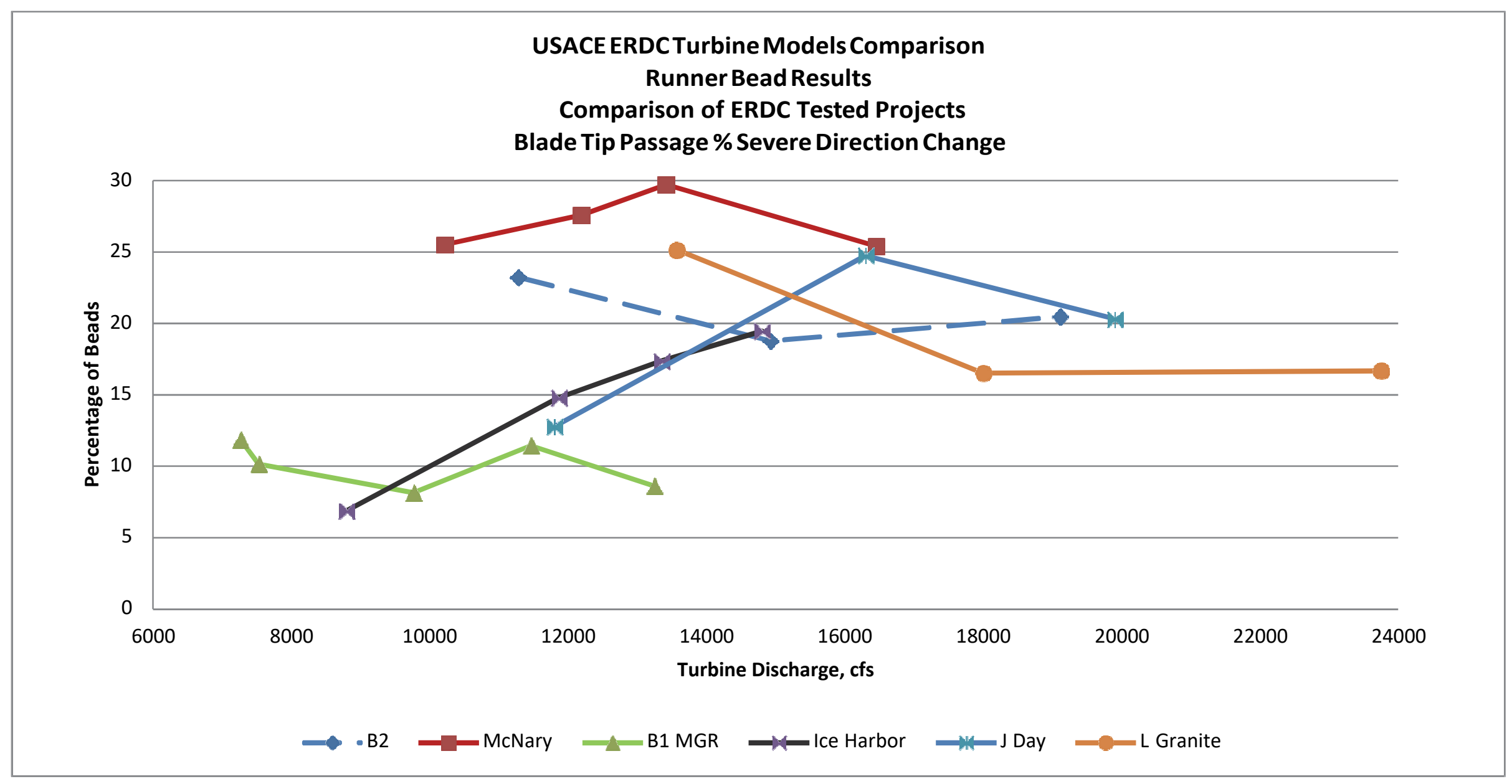




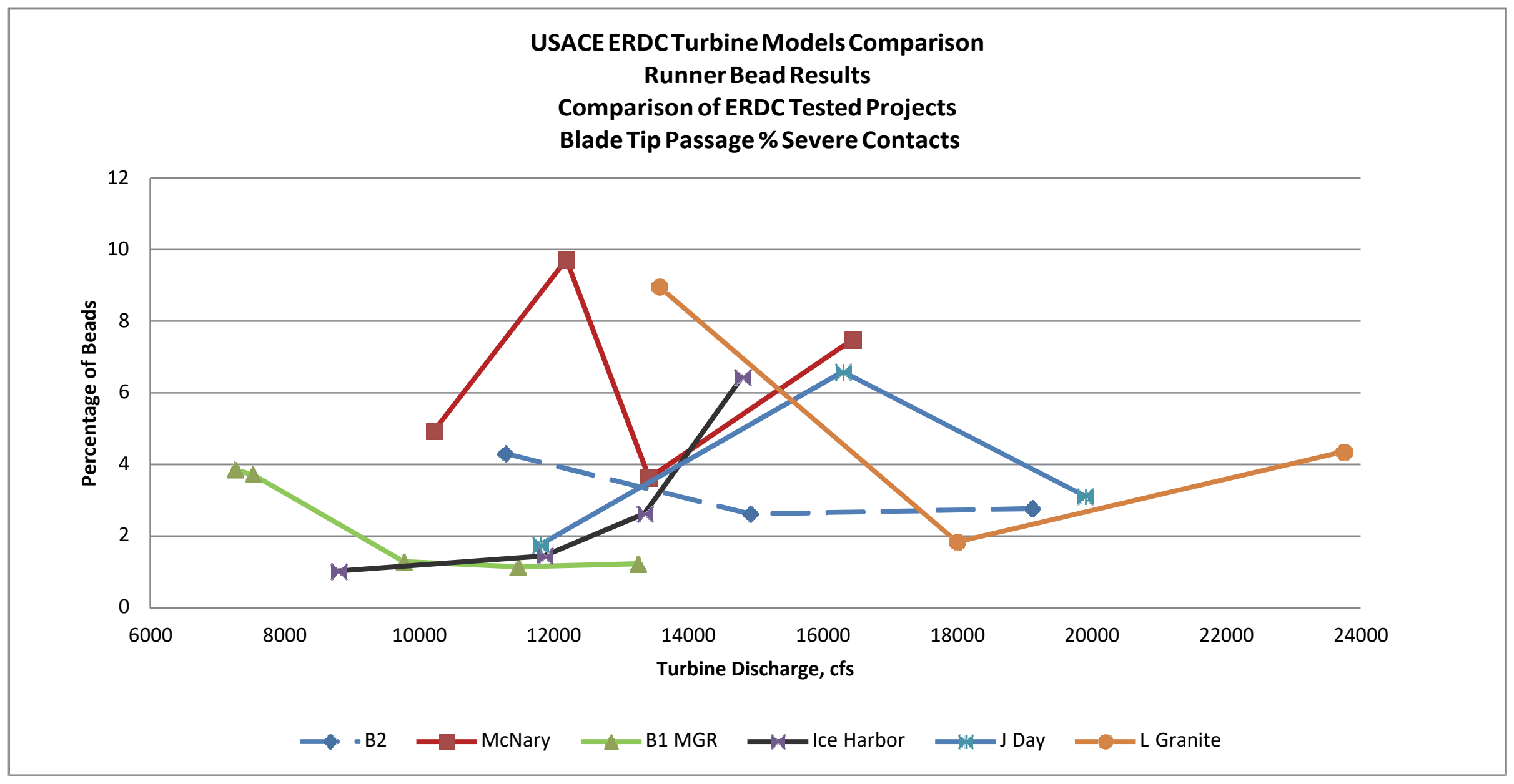




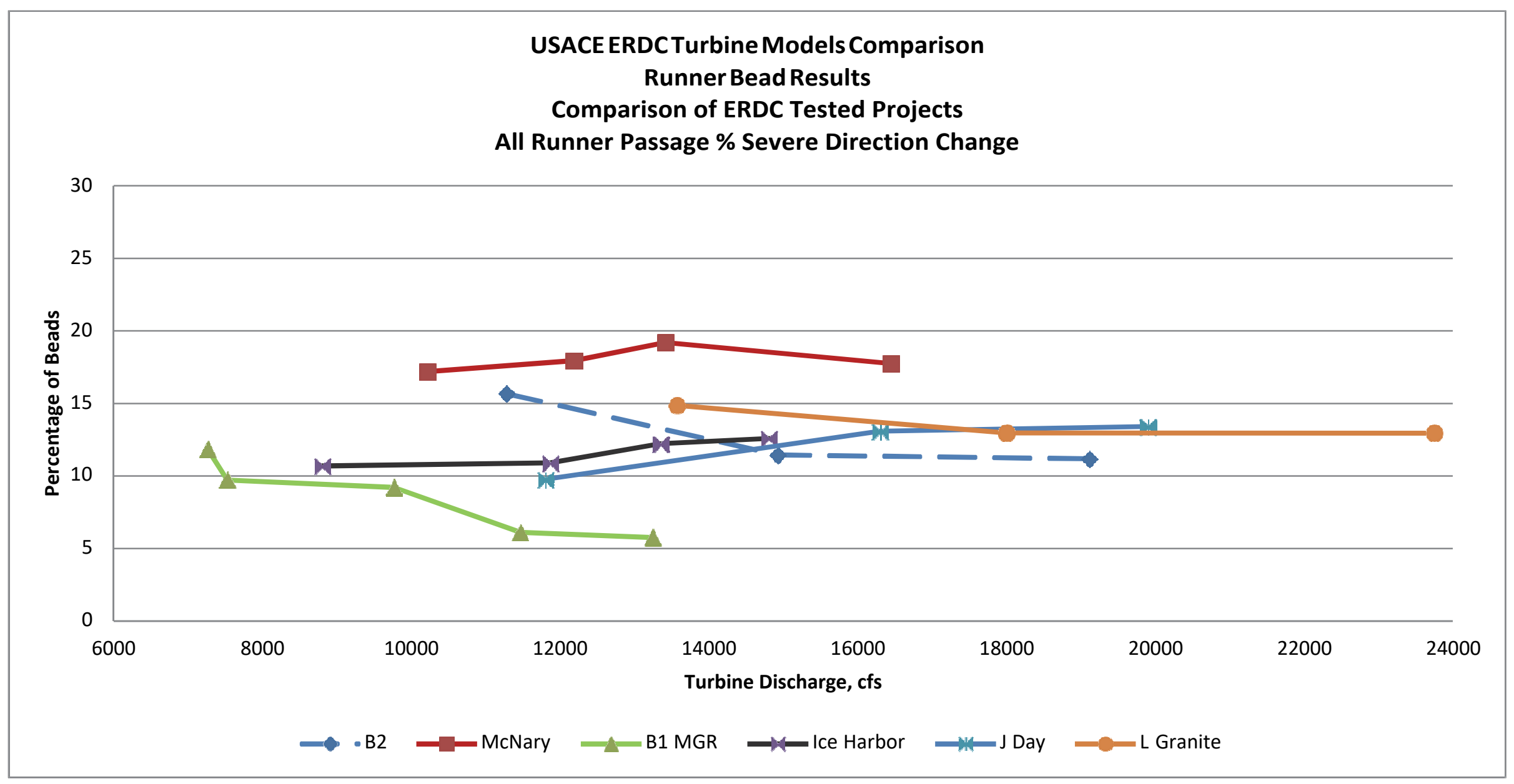




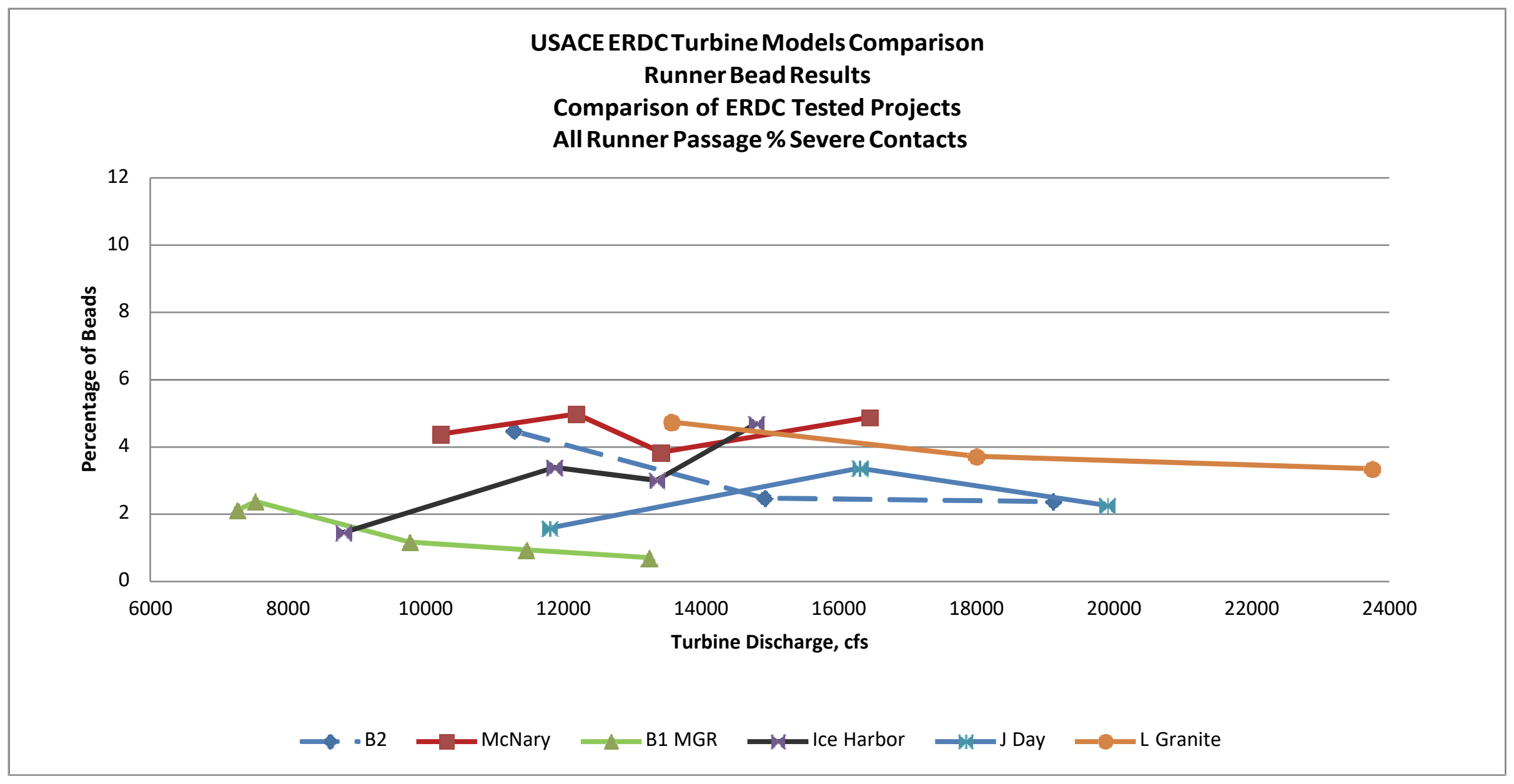




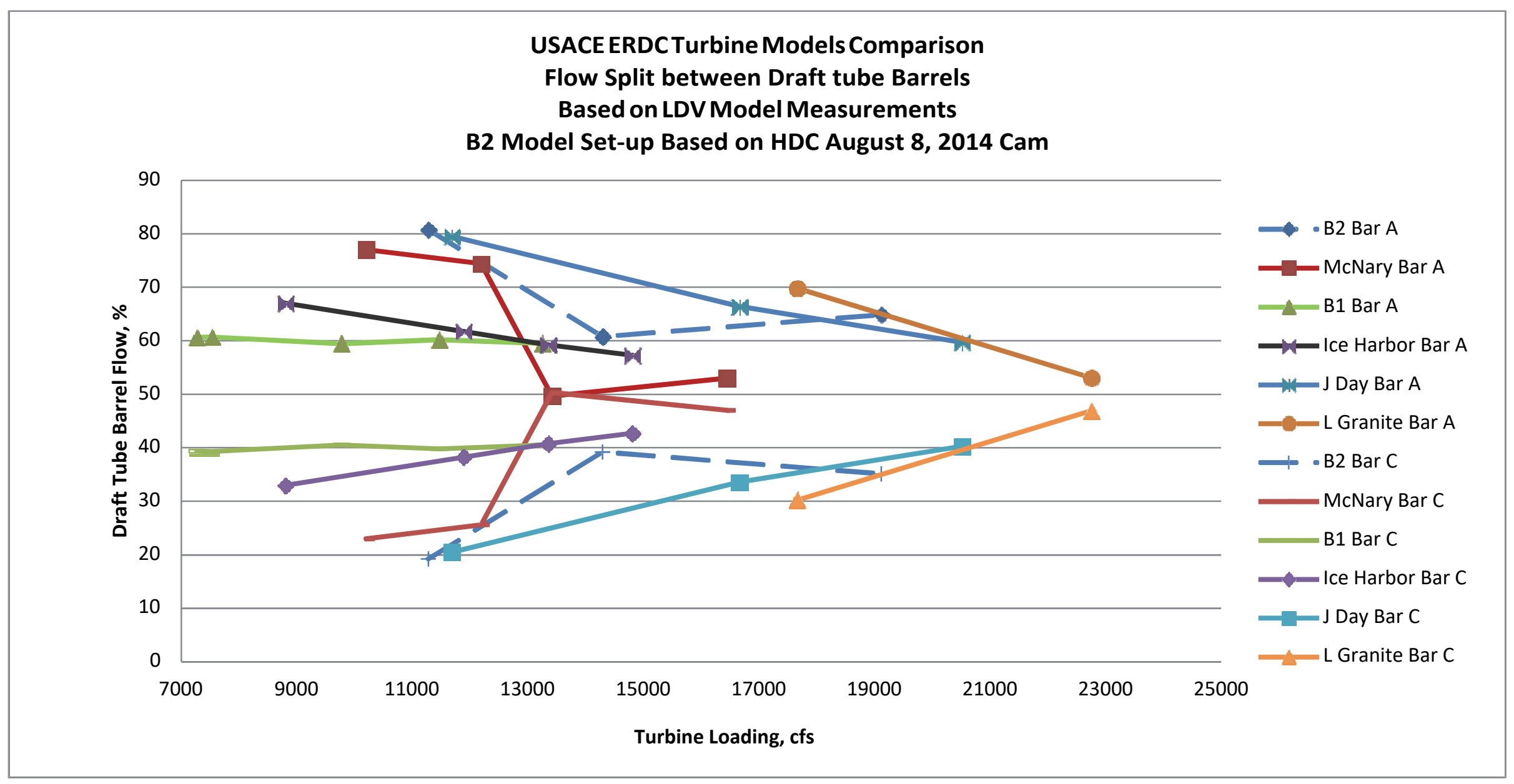




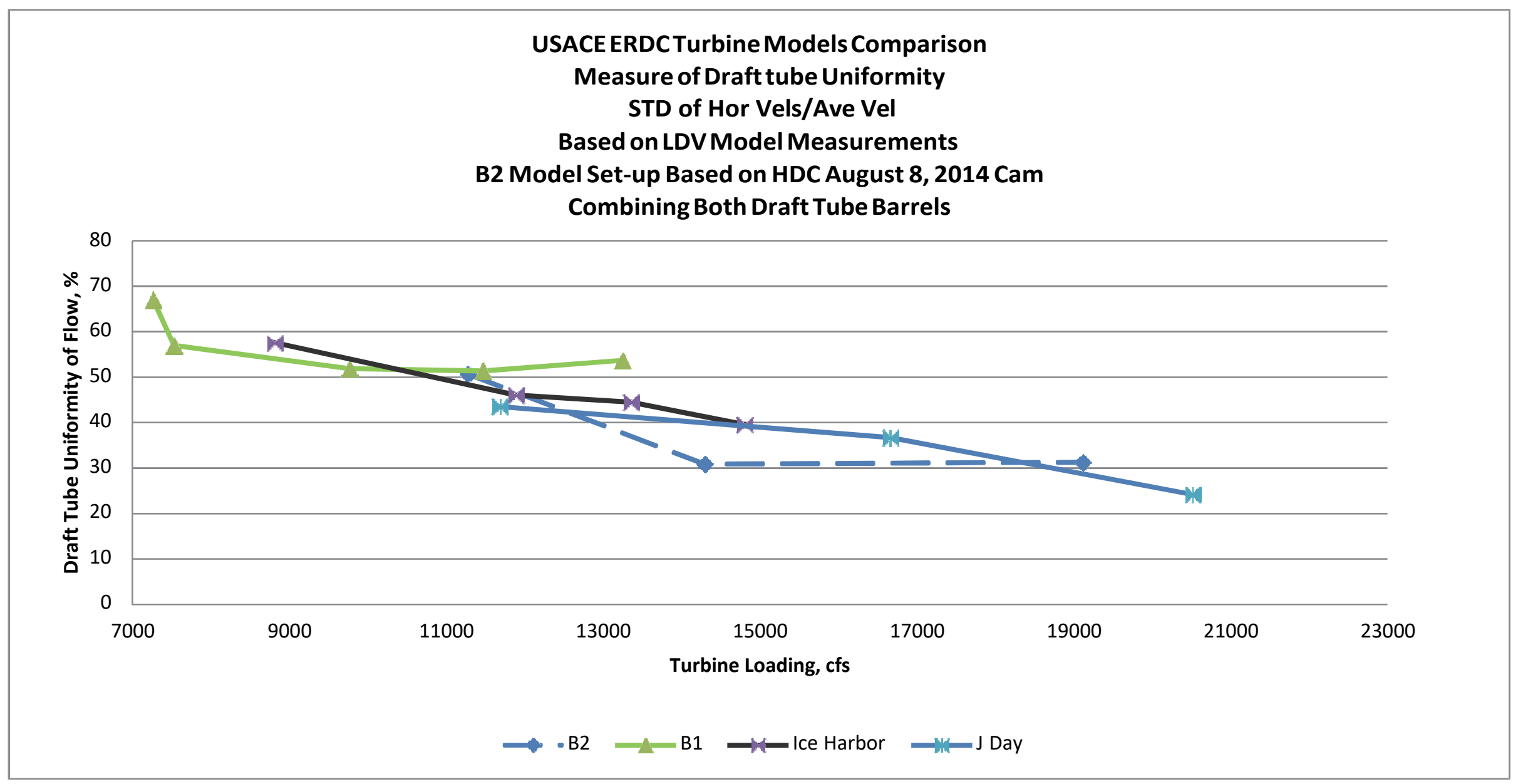




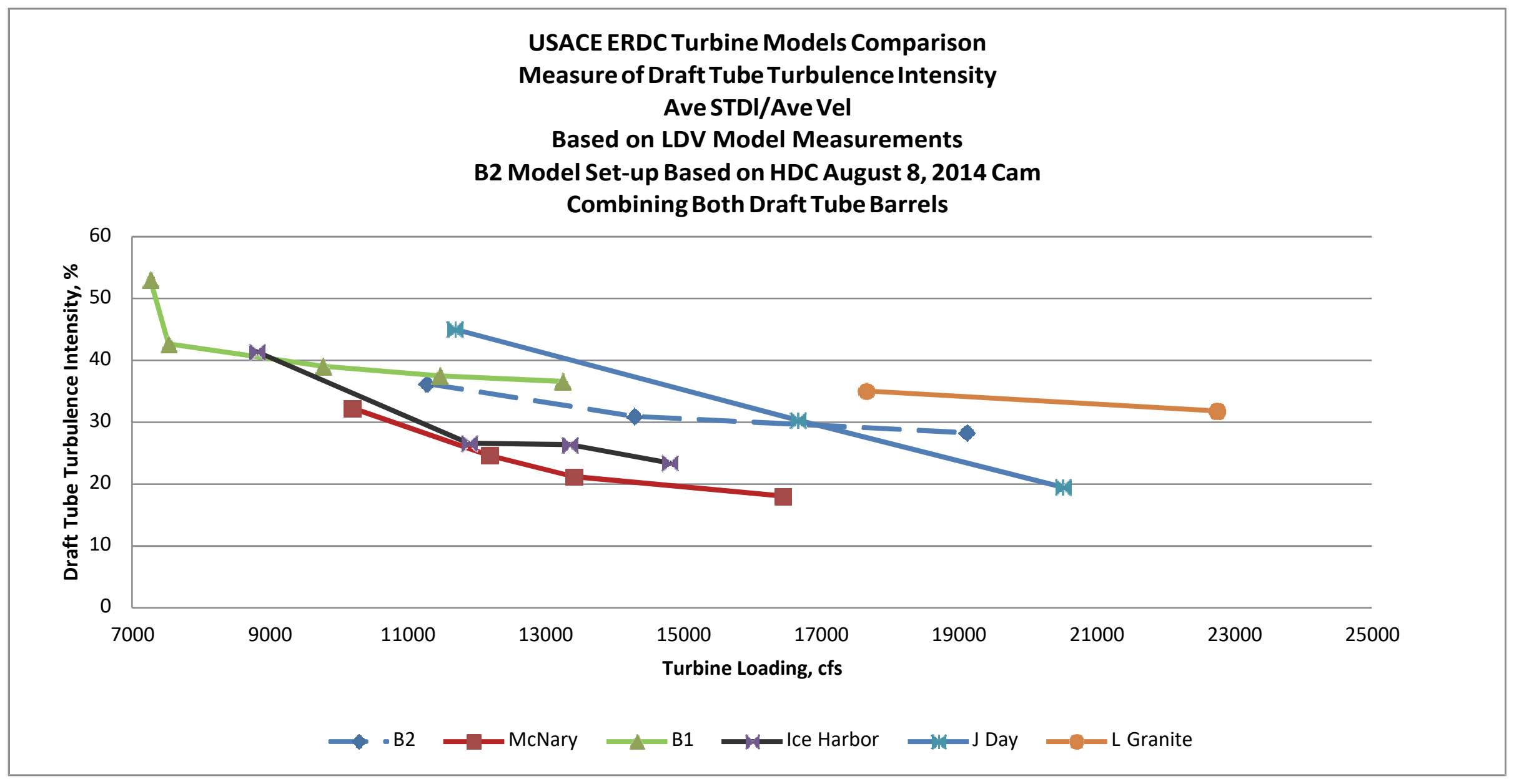




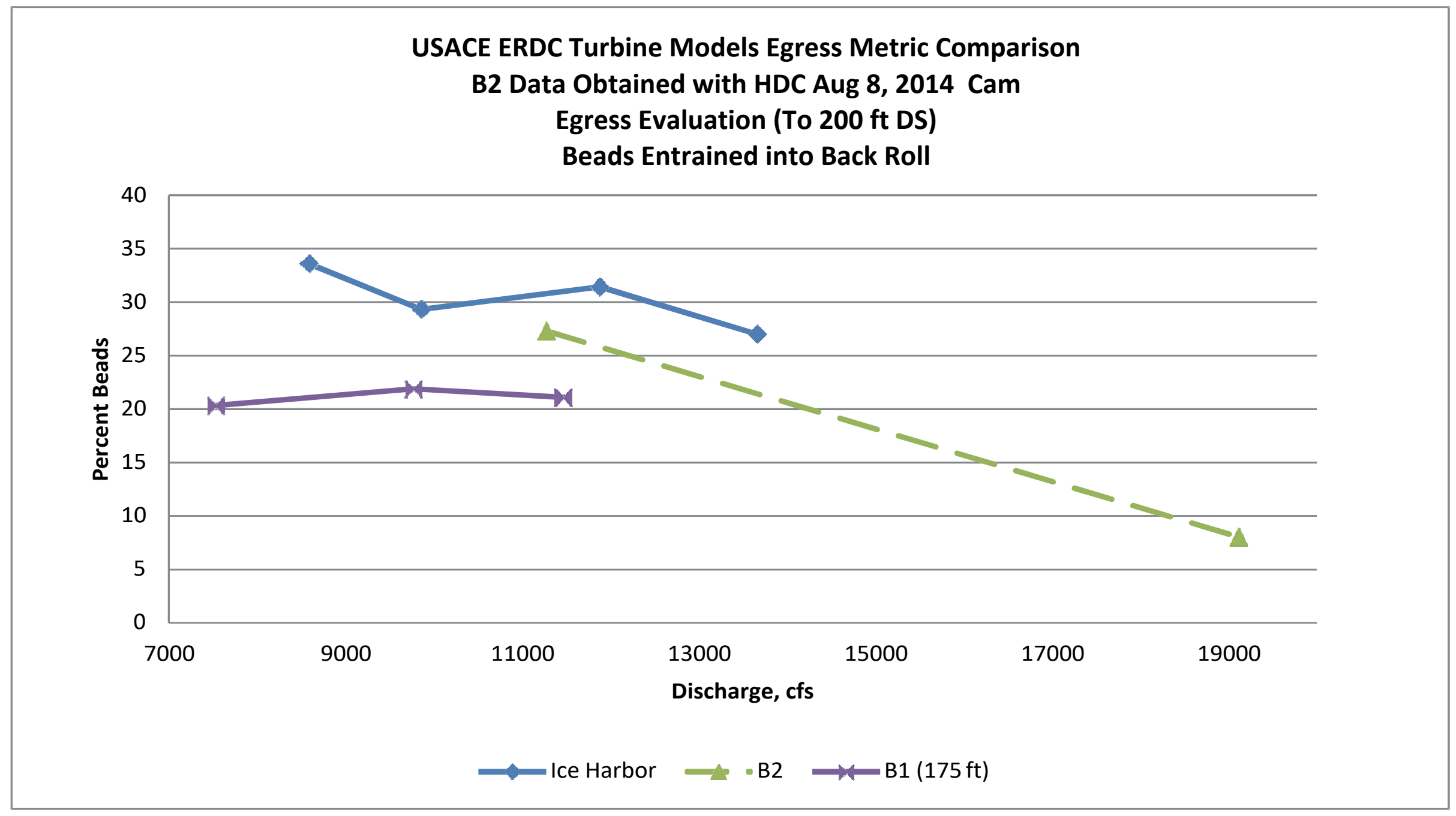




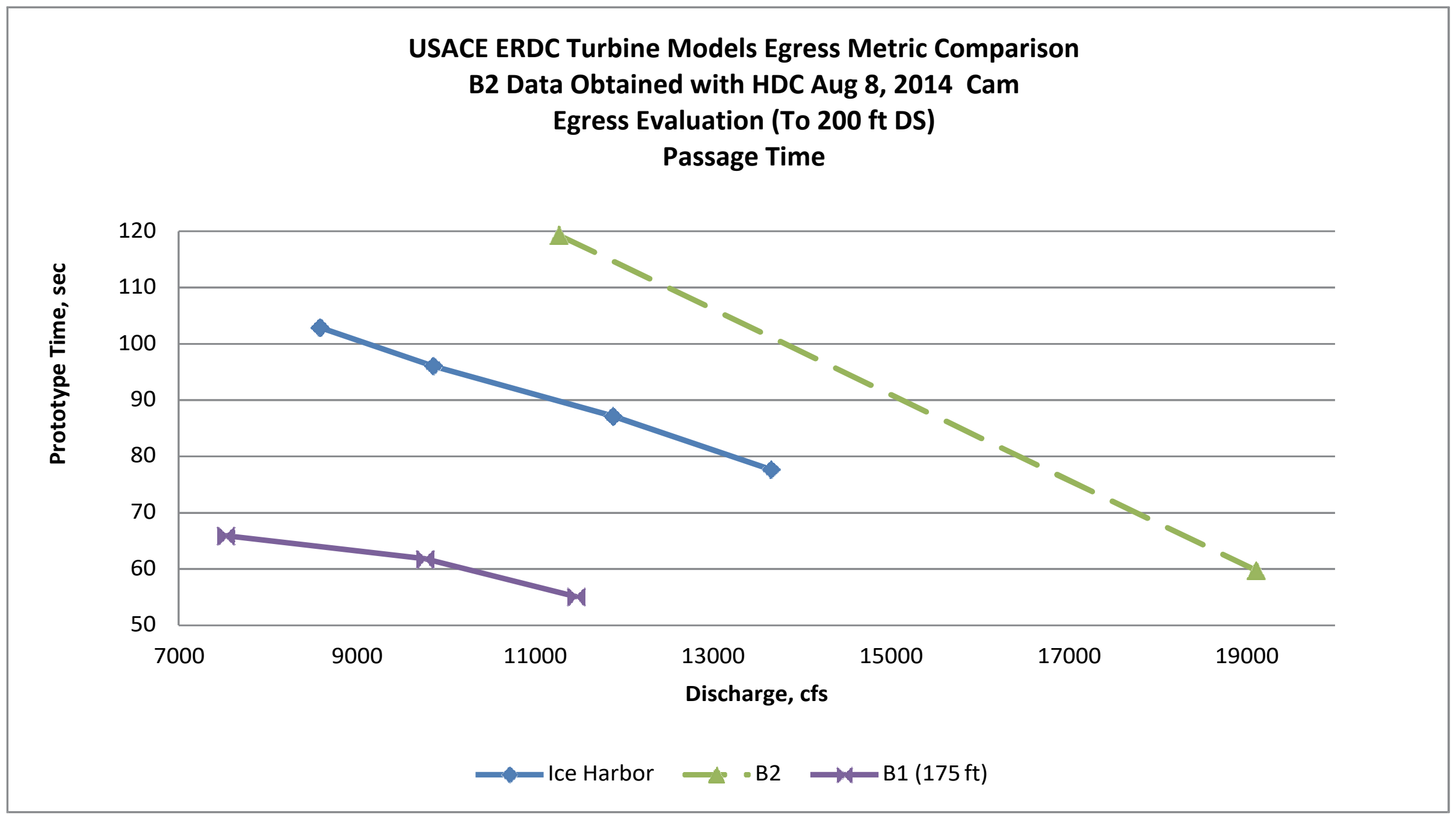




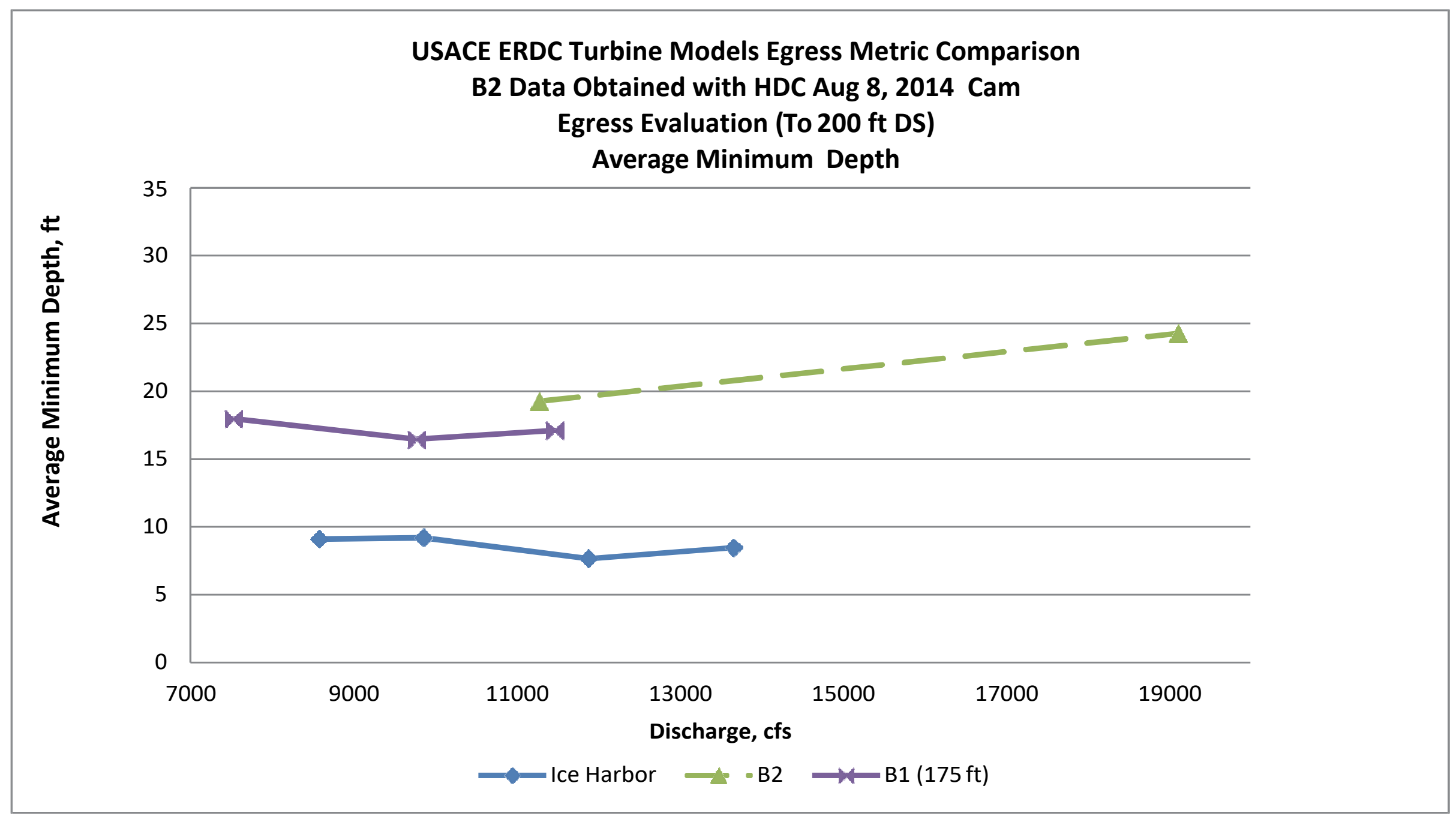




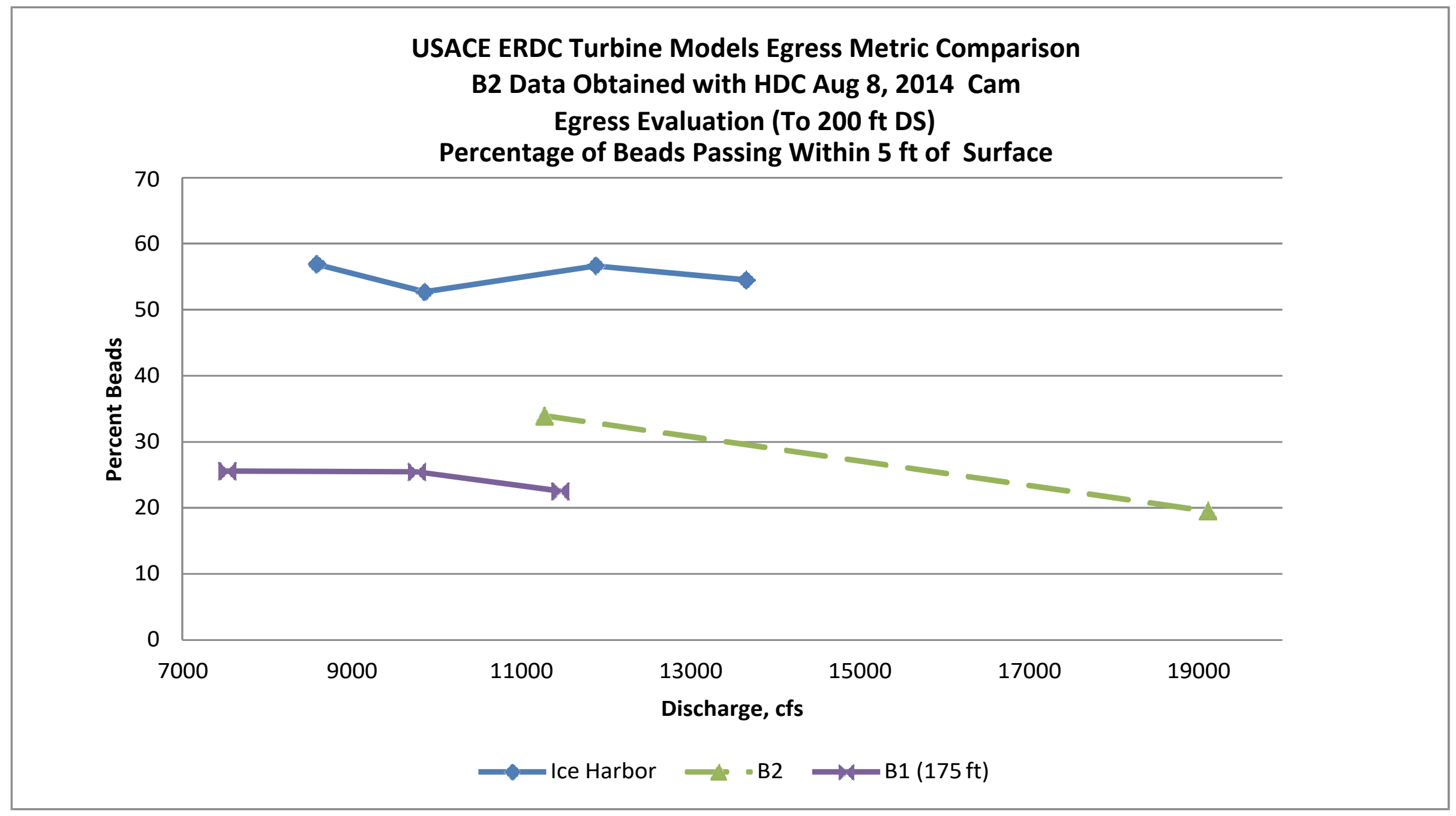




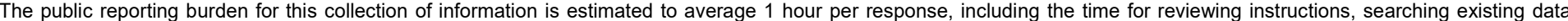

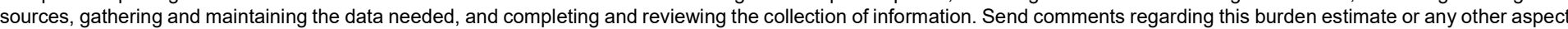

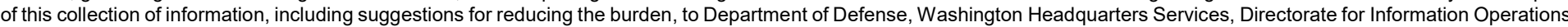

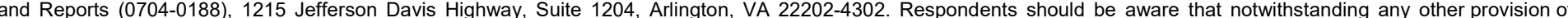
law, no person shall be subject to any penalty for failing to comply with a collection of information if it does not display a currently valid OMB control number. PLEASE DO NOT RETURN YOUR FORM TO THE ABOVE ADDRESS.

\begin{tabular}{l|l|l}
\hline 1. REPORT DATE & 2. REPORT TYPE & 3. DATES COVERED (From - To) \\
August 2018 & Final Report
\end{tabular}

\section{TITLE AND SUBTITLE}

Bonneville Second Powerhouse ERDC Turbine Model Operating Range Investigation 5a. CONTRACT NUMBER

5b. GRANT NUMBER

5c. PROGRAM ELEMENT NUMBER

\section{AUTHOR(S)}

Robert A. Davidson

\section{5d. PROJECT NUMBER}

\section{5e. TASK NUMBER}

\section{5f. WORK UNIT NUMBER}

157101

\section{PERFORMING ORGANIZATION NAME(S) AND ADDRESS(ES) (see reverse)}

Coastal and Hydraulics Laboratory

U.S. Army Engineer Research and Development Center

3909 Halls Ferry Road

Vicksburg, MS 39180-6199

9. SPONSORING/MONITORING AGENCY NAME(S) AND ADDRESS(ES)

U.S. Army Corps of Engineers

Washington, DC 20314-1000

\section{PERFORMING ORGANIZATION REPORT NUMBER}

ERDC/CHL TR-18-13

\section{SPONSOR/MONITOR'S ACRONYM(S)} USACE

\section{SPONSOR/MONITOR'S REPORT} NUMBER(S)

\section{DISTRIBUTION/AVAILABILITY STATEMENT}

Approved for public release; distribution is unlimited.

\section{SUPPLEMENTARY NOTES}

\section{ABSTRACT}

The Bonneville Second Powerhouse (B2) turbine model investigations were performed in support of the joint U.S Army Corps of Engineers, Portland and Walla Walla Districts, Turbine Survival Program (TSP). The TSP was developed to evaluate juvenile fish passage through turbines, with emphasis on identifying turbine structures and operations responsible for fish injury. The purpose of this B2 turbine model study was to investigate potential risk of injury to juvenile fish passing through all regions of the B2 turbines water passageway, using the existing 1:25 scale physical hydraulic model of the B2 turbines. The model investigations were divided into five study areas. These include the stay vane and wicket gate cascade, the runner, the region immediately below the runner, the exit of each of the two draft tube barrels, and the immediate tailrace region. Results from this model investigation indicate operations with steeper blade angles, resulting in higher unit discharge, create better passage conditions for fish. Fewer severe contacts with the turbine runner and less severe change in direction occur at steeper blade angles. The draft tube performs better at steeper blade angles, and the quality of flow exiting the draft tube is better at steeper blade angles. In addition, model experiments indicate egress conditions may be better at steeper blade angles.

\section{SUBJECT TERMS}

Bonneville Dam (Or. And Wash.), Fishes_Effect of dams on, Hydraulic models, Hydraulic turbines, Hydroelectric generators

16. SECURITY CLASSIFICATION OF:

\begin{tabular}{|l|l|l|l} 
a. REPORT & b. ABSTRACT & c. THIS PAGE & ABSTRACT \\
Unclassified & Unclassified & Unclassified & SAR
\end{tabular}

18. NUMBER OF PAGES

189 19a. NAME OF RESPONSIBLE PERSON

Robert A. Davidson

19b. TELEPHONE NUMBER (Include area code) 601-634-3052 